$$
\begin{aligned}
& \text { USP - UNIVERSIDADE DE SÃO PAULO } \\
& \text { IGC - INSTITUTO DE GEOCIÊNCIAS }
\end{aligned}
$$

\title{
INVESTIGAÇÃO HIDROGEOLÓGICA DAS \\ OCORRÊNCIAS TERMAIS E TERMO-MINERAIS DA REGIÃO CENTRO-SUL DA BORDA ORIENTAL DO \\ ESTADO DE SANTA CATARINA E POSSÍVEIS \\ MODELOS GENÉTICOS
}

Rodrigo Del Olmo Sato

Orientador: Prof. Dr. Uriel Duarte

\section{DISSERTAÇÃO DE MESTRADO}

Programa de Pós-Graduação em Recursos Minerais e Hidrogeologia 
ERRATA 
À meus pais Miltom Sato (in Memoriam) e Asunción del Olmo Sato

iii 


\section{AGRADECIMENTOS}

Devo em primeiro lugar agradecer a uma grande amiga que me incentivou a fazer este mestrado, pois sem o incentivo dela, talvez esta idéia tardasse alguns anos em se concretizar. A você Luciana Witovisk Gussela, meus sinceros agradecimentos. Agradeço também a meu Orientador Prof. Dr. Uriel Duarte, pela paciência em guiarme neste trabalho e por ser um bom amigo. Não poderia esquecer meu colega Geógrafo Kleber Cavazza que muito me ajudou nestes 2 anos, com dicas de como sobreviver em São Paulo e pela ajuda nas correções e sugestões. Agradeço também a dois grandes colegas de profissão que me auxiliaram em inúmeras e importantes discussões acerca da geologia Catarinense, os geólogos Hélvio Luiz Deboni e Gabriel Oniris do Amaral Velho, ícones da geologia no Estado de Santa Catarina. Agradeço também a minha família, meu porto seguro, onde pude ancorar com segurança em momentos de tempestade em minha vida. Agradeço também os recursos da CAPES concedidos pela Coordenadoria de Pós-Graduação através do Instituto de Geociências- IGc-USP. E por fim, agradeço a todos que mesmo não nomeados, me auxiliaram direta ou indiretamente até a conclusão deste trabalho. 


\section{SUMÁRIO}

Errata

Dedicatória

Agradecimentos

iv

Sumário V

Lista de Figuras

Lista de Tabelas

Lista de Gráficos

Lista de Abreviaturas e Siglas

Resumo

XV

Abstract

1 Introdução

$2 \quad$ Objetivo

$3 \quad$ Metodologia

$\begin{array}{lll}3.1 & \text { Bibliografia de Apoio } & 11\end{array}$

3.2 Coleta e apresentação dos dados $\quad 14$

3.2.1 Inventário das Fontes Termais 14

3.2.2 Trabalhos de Campo 15

3.2.3 Caracterização Físico-química das Fontes Termais 16

3.2.4 Estudos Técnico-econômicos 17

4 Legislação e classificação das Fontes termais e Termo-minerais 18

5 Caracterização da Geologia Regional e da Área de Pesquisa 20

$\begin{array}{lll}5.1 & \text { Histórico } & 20\end{array}$

5.2 Arqueano / Proterozóico Inferior 22

5.2.1 Complexo Tabuleiro 22

5.2.2 Complexo Águas Mornas 22

5.2.2.1 Faixa Granito-gnaissica Santa Rosa de Lima/ Tijucas 23

5.2.2.2 Faixa Granito-gnaissica Garopaba 23

5.3 Mesoproterozóico / Eo-Paleozóico 
5.3.1 Grupo Itajaí 23

5.3.1.1 Formação Campo Alegre 24

5.4 Eo-Paleozóico 25

5.4.1 Suíte Intrusiva Subida

5.4.1.1 Suíte Intrusiva Pedras Grandes 26

5.5 Paleozóico Inferior / Médio 27

5.5.1 Formação Rio do Sul 27

5.6 Paleozóico Superior / Mesozóico 27

5.6.1 Formação Iratí 27

5.6.2 Formação Serra Alta 28

5.6.3 Formação Terezina 29

5.6.4 Formação Rio do Rasto 29

5.6.5 Formação Botucatú 30

5.6.6 Formação Serra Geral 30

5.6.7 Corpo Alcalino de Anitápolis 31

5.7 Cenozóico 32

5.7.1 Neógeno - Depósitos recentes 32

5.7.2 Depósitos Aluviais e Coluviais 32

5.7.3 Sedimentos Marinhos 32

5.8 Geologia de Detalhe da Área de Pesquisa 34

5.8.1 Área 01 - Santo Amaro da Imperatriz, Águas Mornas, São José e Palhoça 34

5.8.2 Área 02 - Tubarão, Pedras Grandes, Gravatal e Região 36

5.9 Caracterização do Arcabouço Tectônico Regional e da Área de Pesquisa $\quad 40$

5.9.1 Tectônica Regional $\quad 40$

5.9.2 Tectônica da Área de Pesquisa 43

5.9.2.1 Área 01 - Santo Amaro da Imperatriz, Águas Mornas, São José e Palhoça 43

5.9.2.2 Área 02 - Tubarão, Pedras Grandes, Gravatal e Região 
6 Características Fisiográficas $\quad 45$

6.1 Características Climáticas 45

6.1.1 Pluviosidade 48

6.1.2 Temperatura $\quad 50$

6.1.3 Evapotranspiração Potencial 51

6.1.4 Correlação entre Precipitação e Evapotranspiração Potencial 52

6.1.5 Tipos climáticos Regionais 53

6.2 Geomorfologia 54

6.3 Hidrografia 56

6.4 Vegetação 56

6.5 Solos da Área pesquisada 58

7 Termalismo e Modelos Genéticos Aplicáveis 60

7.1 Convecção 65

7.2 Fluxo de Calor nos Continentes 66

7.3 Análise Global da distribuição do Fluxo de Calor ao longo da Terra 68

7.4 Estrutura Térmica do Manto e do Núcleo 69

7.5 História do Termalismo no Brasil 73

8 Características Físico-químicas das Águas Termais e Termominerais de Santa Catarina $\quad 77$

8.1 Características Químicas 79

8.1.1 Radioatividade 83

8.2 Características Físicas 83

8.2.1 Temperatura $\quad 83$

9 Termalismo em Santa Catarina $\quad 89$

$\begin{array}{lll}9.1 \text { Introdução } & 89\end{array}$

9.2 Histórico de Exploração de águas Termais no Estado de $\begin{array}{ll}\text { Santa Catarina } & 91\end{array}$

9.3 Santo Amaro da Imperatriz 93

9.4 Águas Mornas 98

9.5 Gravatal 101 
$\begin{array}{lll}9.6 & \text { Tubarão } & 102\end{array}$

$\begin{array}{lll}9.7 & \text { Pedras Grandes } & 103\end{array}$

$\begin{array}{lll}9.8 & \text { Imaruí } & 104\end{array}$

9.9 Modelos Genéticos Propostos para as Águas Termo-minerais do Estado de Santa Catarina

9.9.1 Modelo do Vulcanismo no Mesozóico - Triássico ao Juro-Cretáceo

9.9.2 Modelo do Vulcanismo Alcalino - Cretáceo Superior até o Eoceno

9.9.3 Modelo do Gradiente Geotérmico 107

9.9.4 Modelo Genético Associado 109

9.9.4.1 Primeira Fase Termo-tectônica 109

9.9.4.2 Segunda Fase Termo-tectônica 113

9.9.4.3 Terceira Fase Termo-tectônica 115

9.9.4.4 Quarta Fase Termo-tectônica 118

10 Características Sócio-econômicas das Populações nos

Municípios com Ocorrência de Águas Termais e Termo-minerais

10.1 Santo Amaro da Imperatriz - Área $01 \quad 127$

10.2 Águas Mornas - Área $01 \quad 128$

$\begin{array}{lll}10.3 \text { Gravatal - Área } 02 & 129\end{array}$

10.4 Pedras Grandes - Área $02 \quad 129$

10.5 Setores Industriais para as Águas Termo-minerais 130

10.5.1 A Indústria da Água Envasada 130

10.5.2 A Indústria dos Balneários 132

10.6 Breve Comentário sobre o Desenvolvimento Sustentável e Turismo Associado às Águas Termais e Termo-minerais 133

10.6.1 Conceitos 133

10.6.2 Balneabilidade e Termalismo 136

11 Conclusões 140

12 Bibliografia 143

13 Anexos 157 


\section{LISTA DE FIGURAS}

\section{Capítulo 1}

Fig. 1.1 Ruínas de Mohenjo-Daro, distrito de Larkana, Sindh, Paquistão. 01 (Fonte: www.harappa.com)

Fig. 1.2 Vista do complexo Balneário de Mohenjo-Daro 02

(Fonte: www.harappa.com)

Fig. 1.3 Termas de Stabiano em Pompéia (Fonte: www2.pompeiisites.org) 04

Fig. 1.4 Termas Romanas de Évora, localizadas no subsolo dos Paços do Conselho de Évora - Portugal (Fonte: www.cm-evora.pt)

Fig. 1.5 Mulheres se banhando em um banho público Japonês - Autor: Torii Kiyonaga (1752 - 1815) (Fonte: www.japonismus.com) 06

Fig. 1.6 Termas de Bath - Inglaterra (Fonte: www.imagensviagens.com/bath.htm)

Fig. 1.7 Lord Willian Thonson Kelvin (1824-1907)

(fonte: scienceworld.wolfram.com/biography/Kelvin.html)

\section{$\underline{\text { Capítulo } 5}$}

Fig. 5.1 Mapa Geológico detalhado da região chamada Águas Mornas, Município de Imaruí

Fig. 5.2 Mapa do Arcabouço Estrutural da Bacia do Paraná e Santa Catarina 42

\section{Capítulo 6}

Fig. 6.1 O ciclo Hidrológico (Fonte: PORTO, 1973)

Fig. 6.2 Disposição da água nos diferentes níveis de circulação

Fig. 6.3 Vista da Planície Costeira a partir da serra do Leste Catarinense. A foto foi tirada no extremo sul da área, próximo ao município de Tubarão.

Fig. 6.4 Vista do afloramento da Suíte Intrusiva Pedras Grandes a partir da Planície Costeira. A foto foi tirada na porção central da área, próximo ao município de Imbituba.

\section{$\underline{\text { Capítulo } 7}$}

Fig. 7.1 Relação entre temperatura e profundidade. (Fonte: MIRANDA et alli, 2005)

Fig. 7.2 Modelo matemático de convecção do manto em 3D. Os azuis representam as temperaturas mais fria do que médias, temperaturas médias são as amarelas e verdes, e temperaturas mais quente do que médias do vermelho. (Fonte: Cardiff Marine Institute - www.earth.cf.ac.uk)

Fig. 7.3 Fluxo de Calor nos Continentes. Em vermelho as regiões mais quentes e com vulcanismo ativo e em azul as mais frias.

Observar a cadeia meso-oceânica entre Américas e África. 
(MULLER et alli, 1997)

Fig. 7.4 Modelo do núcleo 3D em vermelho, com diferenças de viscosidade.

A zona da viscosidade baixa (no azul) corresponde ao manto

Superior da terra. (Fonte: Nasa. ct.gsfc.nasa.gov/olson.finalreport)

\section{$\underline{\text { Capítulo } 8}$}

Fig. 8.1 Mapa de Fluxo geotérmico do Estado de Santa Catarina. (fonte:

CARDOSO, 2004)

\section{Capítulo 9}

Fig. 9.1 mapa de Santa Catarina com os municípios com ocorrências Termais e termo-minerais conhecidas

Fig. 9.2 Em sentido Horário da foto maior, vistas da Estâncias de Horrogate e abaixo o "The Royal Bath Hospital", balneário para tratamento crenoterápico de Horrogate. (Fonte: www2.northyorks.gov.uk)

Fig. 9.3 Em sentido Horário da foto maior, vistas da Estâncias de Horrogate E abaixo o "The Royal Bath Hospital", balneário para tratamento crenoterápico de Horrogate. (Fonte: www2.northyorks.gov.uk)

Fig. 9.4 Em sentido Horário da foto maior, vistas da Estâncias de Horrogate E abaixo o "The Royal Bath Hospital", balneário para tratamento crenoterápico de Horrogate. (Fonte: www2.northyorks.gov.uk)

Fig. 9.5 Homenagem ao dia do massacre da Guarda Imperial.

Fig. 9.6 índios botocudos do Vale do Itajaí in "Índios e Brancos no Sul do Brasil" - Sílvio C. dos Santos, 1973

Fig. 9.7 Vista das termas de Caldas da Imperatriz no Início do séc. XX.

Fig. 9.8 Vista geral das instalações do Águas Mornas Palace Hotel Município de Águas Mornas. (fonte: GEOCON Geologia e Consultoria Ltda.)

Fig. 9.9 Fonte Crystal - Município de Águas Mornas. Temperatura inicial de $41,6^{\circ}$, chegando a $45^{\circ}$ após 30 horas de bombeamento, o mais quente do Estado de Santa Catarina (Fonte: GEOCON Geologia e Consultoria Ltda.)

Fig. 9.10 Vista das Termas de Gravatal. (Fonte: www.malhariaeliani.com.br)

Fig. 9.11 Vista da surgência no local denominado "Águas Mornas", município de Imaruí, antes da construção da caixa de captação

Fig. 9.12 Vista da surgência no local denominado "Águas Mornas", no município de Imaruí, captada através de uma caixa de captação (a esquerda), posteriormente foi feito um poço tubular profundo a direita da foto, com casa de proteção.

Fig. 9.13 Mapa hipotético do supercontinente Rodinia. (fonte: www.scotese.com)

Fig. 9.14 Configuração simplificada da distribuição dos blocos continentais após a quebra do Supercontinente Rodínia. (Modificada de ROGERS, 1996).

Fig. 9.15 Geologia da porção inferior do Gondwana Leste (Ocidental) (600 Ma), com suas principais cadeias Pan-Africanas - Brasilianas e Crátons, em especial o Cinturão Dom Feliciano, que corresponde 
a Atual área pesquisada.

Fig. 9.16 Reconstrução da provável posição das massas continentais no Cambriano Superior, 514 milhões de anos.

(Fonte: www.scotese.com)

Fig. 9.17 Reconstrução da provável posição das massas continentais no Triássico, 237 milhões de anos. Modificado de www.scotese.com (fonte: www.fgel.uerj.br/Dgrg/webdgrg/Timescale/)

Fig. 9.18 Compartimentação geotectônica da região estudada

Fig. 9.19 Reconstrução da provável posição das massas continentais no Jurássico, 125 milhões de anos. Modificado de www.scotese.com (fonte: www.fgel.uerj.br/Dgrg/webdgrg/Timescale/)

Fig. 9.20 Reconstrução da provável posição das massas continentais no Cretáceo, 94 milhões de anos. (Fonte: www.scotese.com.)

Fig. 9.21 Unidades graníticas do Batólito de Florianópolis na Folha

Criciúma.(SILVA, 2000)

\section{Capítulo 10}

Fig. 10.1 Principais províncias hidrominerais em exploração no Estado de Santa Catarina (Fonte: DNPM - SISMINE / 2004)

Fig. 10.2 Relação entre o tipo de água e número de captações.

(Fonte: DNPM) 


\section{LISTA DE TABELAS}

Capítulo 5

Tab. 5.1 Coluna litoestratigráfica Regional modificada, em destaque (cor azul) as Formações encontradas regionalmente associadas às águas termais e termo-minerais. Referência Projeto Cadastro de Recursos Minerais de Santa Catarina, 1989

Capítulo 6

Tab. 6.1 Precipitação Mensal Média (em mm, sendo os valores em verde os máximos e em laranja os mínimos. (fonte: Séries Históricas da EPAGRI e CLIMERH de 1924 a 2004)

Tab. 6.2 Precipitação anual total (em $\mathrm{mm}$ )

Tab. 6.3 Temperatura média mensal $\left(\mathrm{em}^{\circ} \mathrm{C}\right)$. Fonte: Séries Históricas da EPAGRI e CLIMERH de 1924 a 2004. Em Vermelho as Máximas e em Azul as mínimas.

\section{Capítulo 7}

Tab. 7.1 Relação dos principais isótopos radioativos e sua contribuição em relação ao calor liberado. (MIRANDA et alli, 2005)

\section{Capítulo 8}

Tab. 8.1 Determinações dos Parâmetros físico-químicos das águas minerais de Santa Catarina. Fonte: DNPM

Tab. 8.2 Resultados das medidas das propriedades termofísicas das amostras. (Fonte: Observatório Nacional - ON in "Estudos Geotérmicos no Estado de Santa Catarina", 2004)

Tab. 8.3 Valores médios das Propriedades termofísicas por tipo litológico. (Fonte: Observatório Nacional - ON in "Estudos Geotérmicos no Estado de Santa Catarina”, 2004)

Tab. 8.4 Fluxo geotérmico nas áreas de fontes termais na região leste. (Fonte: Observatório Nacional - ON in "Estudos Geotérmicos no Estado de Santa Catarina", 2004)

Capítulo 10

Tab. 10.1 Processos de Água Mineral e Termo-mineral cadastrados em Santa Catarina Fonte: DNPM 


\section{LISTA DE GRÁFICOS}

$\underline{\text { Capítulo } 06}$

Graf. 6.1 Precipitação Mensal Total (em mm)

Graf. 6.2 Temperaturas medias mensais $\left({ }^{\circ} \mathrm{C}\right)$. Fonte: Séries Históricas da EPAGRI e CLIMERH de 1924 a 2004.

Graf. 6.3 Evapotranspiração potencial x precipitação total mensal na 4 estações meteorológicas.

Capítulo 07

Graf. 7.1 Valores médios para fluxo de calor (Fonte: MIRANDA et alli, 2005) 


\section{LISTA DE ABREVIATURAS E SIGLAS}

DNPM

Departamento Nacional da Produção Mineral

LAMIN

Laboratório de Análises Minerais

CPRM

Companhia de Pesquisa de Recursos Minerais

$\mathrm{CRQ}$

Conselho Regional de Química

GPS

Global Positioning System - Sistema de Posicionamento Global

IBGE Instituto Brasileiro de Geografia e Estatística

ON

Observatório Nacional

IPT

Instituto de Pesquisas Tecnológicas

ATA

Anticiclone Tropical Atlântico Sul

D.C

Depois de Cristo

\section{A.C}

Antes de Cristo

SAD

South America Datum

R.H.C.P

Right Hand Circulay Polarised

$\mathrm{N}$

Norte

$\mathrm{S}$

Sul

W

Oeste

E

Leste

EPAGRI Empresa de Pesquisa Agropecuária e Extensão Rural de Santa Catarina

CLIMERH/CIRAM Centro de Informações de Recursos Ambientais e de Hidrometeorologia

EMBRAPA Empresa Brasileira de Pesquisa Agropecuária

CODISC Companhia Distrito Industrial do Sul Catarinense

ONU Organização das Nações Unidas 


\section{RESUMO}

Este trabalho lança novos dados em relação à gênese das águas termais da região centro-sul da Borda Oriental do Estado de Santa Catarina. Pouco se sabe a este respeito, apesar das águas termais serem exploradas a mais de 180 anos no Estado de Santa Catarina, pouco se falou sobre sua gênese e evolução. Neste trabalho foram reunidos os dados existentes sobre as águas termais e termo-minerais no Estado de Santa Catarina até o presente momento e compilados na forma de tabelas, quadros e modelos genéticos, o que possibilitou lançar novas hipóteses sobre as origens destas águas. Não foram consideradas as ocorrências a Oeste de Santa Catarina por serem captações feitas por poços tubulares profundos e não por surgências naturais ou poços pouco profundos, como ocorre na região centro-sul da Borda Oriental. 


\begin{abstract}
This work intends to dare new basis in relation to the origin of the thermal and thermal-mineral waters in the Centre-South of the Eastern Cost in the state of Santa Catarina. Only a few information about it is available, in spite of the thermal and thermal-mineral waters are being explored over 180 years in the state of Santa Catarina, a few was spoken about their origin and evolution. In this work were joined the information available about the thermal and thermalmineral waters in the state of Santa Catarina until the present moment and compiled in schedules and genetic models that permited to criate new hypothesis about the origin of those waters. The accurences in the West of Santa Catarina were not considered because the captivating is done by deep tubular wells and not by natural existence or by less deep wells like occurs in the Centre-South and the Eastern Cost
\end{abstract}

Key-words: Thermal - Santa Catarina - Genetic Models - Thermal Waters Thermal -Mineral Waters - East Cost. 


\section{1 - INTRODUÇÃO}

Devemos considerar nos dias atuais a importância de vários setores ligados às águas minerais e termo-minerais tais como saúde (crenoterapias, balneoterapias, ingestão medicamentosa), sócio-econômicas (belneabilidade e envase, como gerador de desenvolvimento social) e Cultural (Histórica e cientifica).

Desde épocas remotas as antigas civilizações utilizavam o banho termal como medida terapêutica e social. As mais antigas referencias a este costume são construções dedicadas a banhos termais na Índia, anteriores a 2.000 a.c., na cidade de Mohenjo-Daro (Fotos 1.1 e 1.2). Existem também outras menções de termas em textos gregos e romanos. Uma das citações fala do palácio de Cnossos, na ilha grega de Creta, que foi construído entre os anos de 1.700 a 1400 a.c., contemporaneamente a este período, existem registros de termas na cidade real de Tell El-Amarna, que fica a $180 \mathrm{~km}$ a sul da cidade do Cairo no Egito médio, cujas construções datam de aproximadamente 1350 a.c.

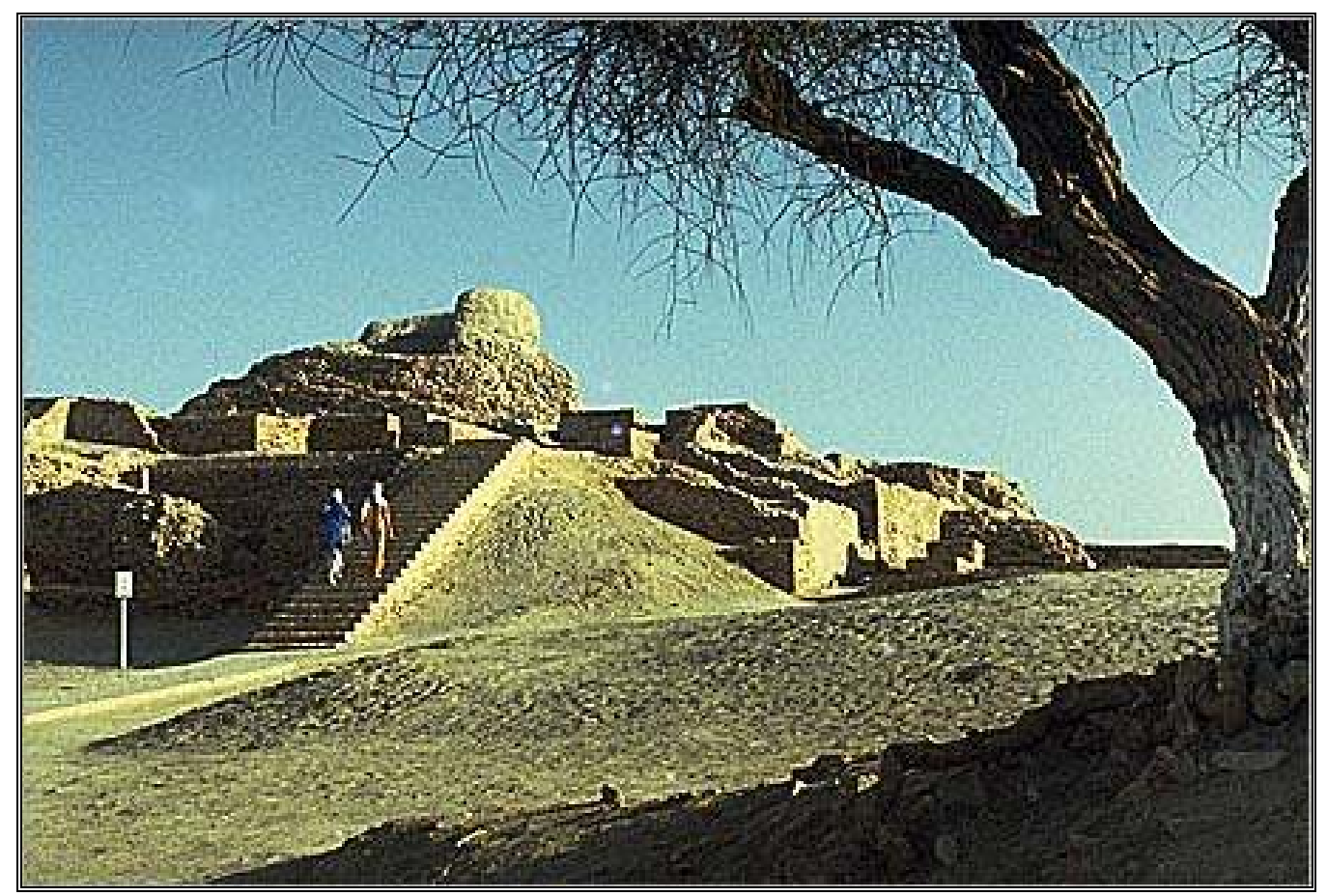

Fig. 1.1 - Ruínas de Mohenjo-Daro, distrito de Larkana, Sindh, Paquistão. (Fonte: http://www.harappa.com) 


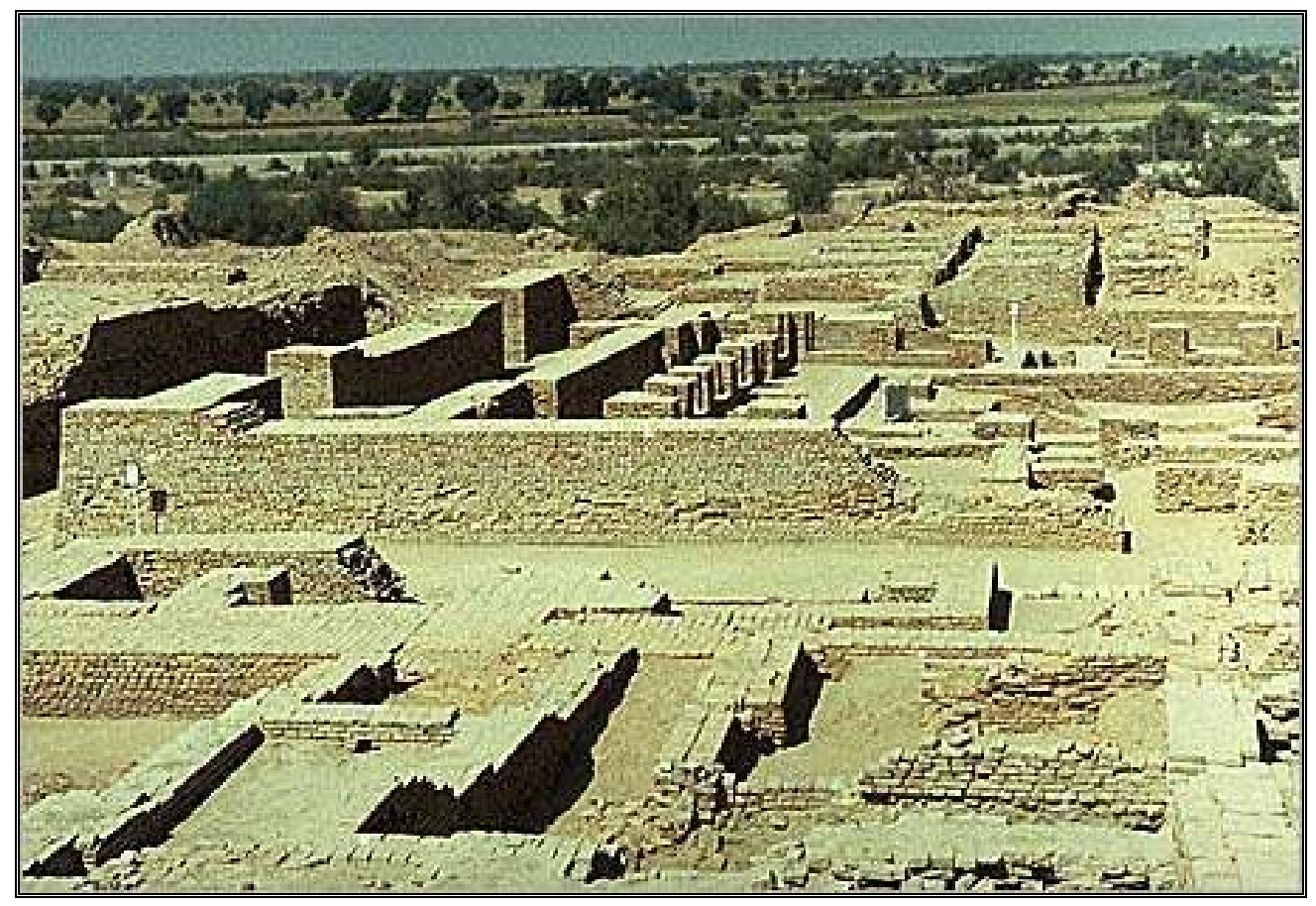

Fig. 1.2 - Vista do complexo Balneário de Mohenjo-Daro (Fonte: http://www.harappa.com)

As antigas termas eram construções simples até o século $V$ a.c, quando os Romanos construíram instalações independentes, com piscinas, salas de vapor, auditório para debates, com isso as termas tornaram-se uma prática que ultrapassava a definição de mero ritual de cuidados corporais para tornar-se um evento social; assim, com esta mentalidade os romanos difundiram a prática dos banhos termais e deram a esta prática o seu auge arquitetônico. Cabe ressaltar que existiam dois tipos de termas neste período, as termas naturais, onde a fonte do termalismo é subterrâneo, e as artificiais, que utilizavam água fria aquecida em fornalhas, já que as ocorrências mundiais das águas termais e termo-minerais é bastante reduzida.

Heródoto, a quem o escritor romano Marcus Tulius Cícero citou como "Pai da história", foi quem lançou as bases para a Crenologia. Em seus escritos estabeleceu o tempo para a cura através do uso de águas minerais e a influência da temperatura das mesmas nas diferentes épocas do ano. Hipocrates, por sua vez, é conhecido como o fundador do estudo do clima, sendo uma de suas obras mais importantes é o "Tratado do ares, das águas e lugares", escrito no século $V$, que ao invés de atribuir origem divina para as enfermidades, discute as causas ambientais das mesmas. 
Plínio, grande enciclopedista romano, foi um astuto observador da vida cotidiana e estudante dos mananciais de águas termais, em busca de conhecimentos a respeito do poder de cura e qualidade das águas. A grande enciclopédia de Gaius Plinius Secundus (23 - 79 d.c), mais conhecido como Plínio "O velho", chamada de "Naturalis Historia", é composta de 37 volumes, destes 10 foram publicados em vida, no ano 77 d.c, os demais foram editados postmortem por seu sobrinho, Plínio "o Jovem".

Das muitas obras de Plínio, esta é a única que chegou até os nossos dias. Sua obra abarca conhecimentos na área de Astronomia, Geografia, Etnologia, Antropologia, Anatomia, Zoologia, Botânica, Mineralogia, Medicina, entre outros. Com seus conhecimentos de amplos campos, acabou por lançar as bases da classificação das águas minerais e seus principais benefícios à saúde.

Outro estudioso da antiguidade a lançar dados sobre os benefícios das águas termais e termo-minerais foi o médico grego Asclepíades (século I a.c.), originário da antiga Bitinia, na Ásia Menor, que acreditava que o movimentos dos "átomos" no corpo era a causa das enfermidades, e recomendava tratamentos curativos por banhos de imersão em águas termais, além de exercícios e dieta balanceada, exatamente como a medicina de hoje recomendaria em um tratamento moderno.

As termas romanas mais antigas que se tem notícia são as de Stabiano na cidade de Pompéia, construída no segundo século antes de cristo. Sua construção é bastante simples e segue um padrão básico que se observa igualmente em outras termas do império romano. Ao redor de um pátio central, chamado de palestra, onde se podia praticar exercícios se encontrava o apodyterium, ou vestiário; o caldarium, era a habitação que continha o alveus, que é a piscina de água quente propriamente dita.

As termas romanas atingiram um refinamento tão grande nas grandes cidades, que ocupavam um espaço considerável, com banhos, saunas e numerosos estabelecimentos anexos. Os banhos de Agrippa (Marcvs Vipsanivs Agrippa - 31 A.C. - 12 D.C), em Roma, hoje desaparecidos, são o primeiro exemplo da concepção monumental das termas romanas dos séculos II e III, das quais as mais famosas são as do imperador Caracalla (Marcvs Avrelivs Septimivs Bassianvs - 211 - 217 D.C.), com bibliotecas, salas de leitura e conversação, ginásios e um 
teatro; e as de Diocletianus (Gaivs Avrelivs Valerivs Diocletianvs - 284 - 305 D.C), a maior de todas, com $140.000 \mathrm{~m}^{2}$

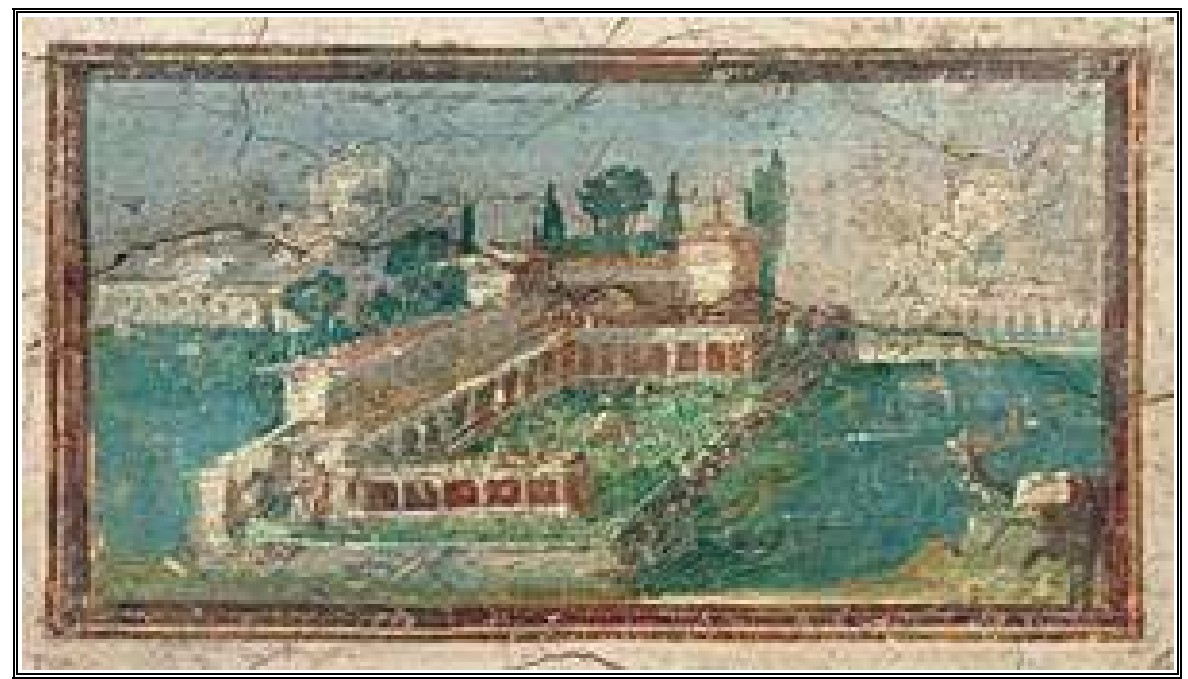

Fig. 1.3 - Termas de Stabiano em Pompéia (Fonte: www2.pompeiisites.org)

As termas públicas romanas também respondiam a uma função social e política e muitas vezes culturais, pois em inúmeras ruínas foram encontradas suntuosas obras de arte, o que indica uma preocupação com a arte e não apenas uma construção com fins terápicos ou recreacionais.

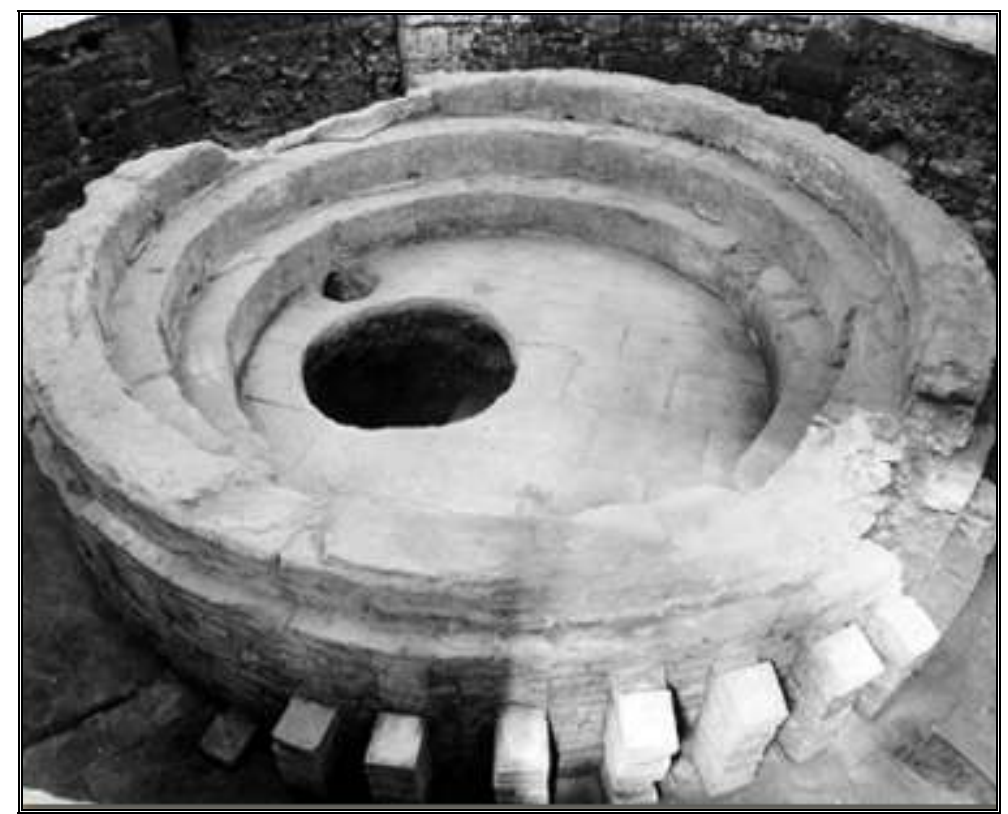

Fig. 1.4 - Termas Romanas de Évora, localizadas no subsolo dos Paços do Conselho de Évora - Portugal (Fonte: http://www.cm-evora.pt) 
Na Escandinávia, aonde a romanização não chegou durante o avanço do império, se generalizou uma espécie de banho a vapor, cuja origem remonta aos povoados das estepes euroasiáticas. Essa pratica era feita em um quarto sem janelas, todo revestido de madeira e com bancos, chamado de "sauna", nome que se popularizou no mundo inteiro. Nela era comum uma reunião familiar onde a temperatura era usada para tonificar a pele e ativar a circulação e ao mesmo tempo, como nas termas romanas, socializar.

Na Europa ocidental a invasão muçulmana se deixou notar por seus banhos públicos, onde a prática do banho era não só recomendada, como era também disseminada pelo alcorão, livro sagrados dos muçulmanos, como uma prática obrigatória para se alcançar a limpeza espiritual. Praticamente toda grande cidade européia teve o seu banho público, sendo suas águas quentes tanto de origem natural como artificial.

Em Constantinopla, na Europa oriental, se mantiveram os costumes oriundos do império romano do ocidente durante a época bizantina, praticas que foram aperfeiçoadas pelos Turcos Otomanos, tanto que esses banhos passaram a se chamar comumente de "banhos turcos".

No Oriente, como o Japão, existe um costume milenar com respeito a limpeza corporal, chamado de misogi, que significa purificação do corpo e era indispensável em qualquer ritual religioso. Cada grande família tem seu próprio banho privado que consiste em uma grande banheira feita de madeira ou escavada na rocha onde a água termal é canalizada, ou simplesmente a construção é feita diretamente sobre as fraturas onde convergem as águas termais. Esta banheira era originalmente chamada de ishiburo ou Iwaburo, mas atualmente é chamado de Ofurô. As famílias menores ou menos abastadas recorriam aos banhos públicos, bastante comum nas grandes cidades. Este costume ainda é adotado no Japão.

Por ser um país vulcânico existem no Japão mais de 25 mil fontes termais, com temperaturas que podem ultrapassar os $100^{\circ} \mathrm{C}$. Os antigos japoneses, rodeados pelas águas minerais quentes, viram nestas fontes uma forma de aproveitar esta ocorrência natural em seu benefício. 


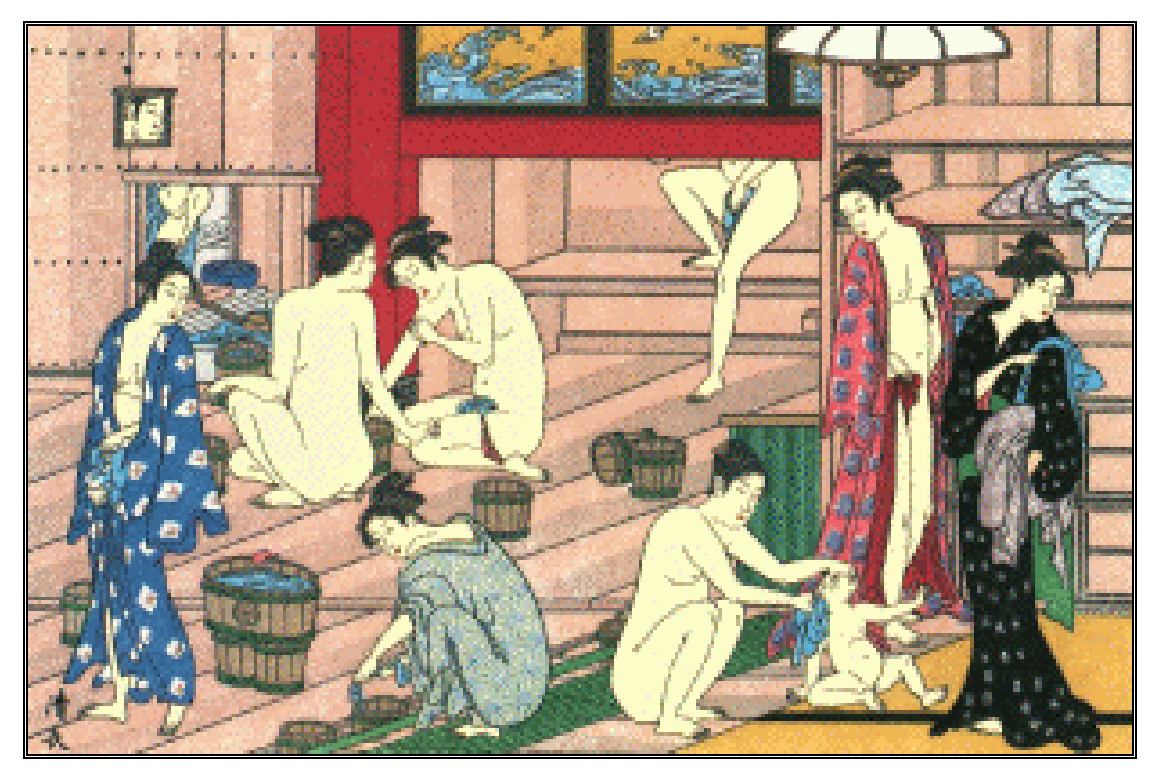

Fig. 1.5 - Mulheres se banhando em um banho público Japonês - Autor: Torii Kiyonaga (1752 - 1815) (Fonte: http://www.japonismus.com/art-bain-origines.html)

Durante a Idade Média a igreja cristã considerava a limpeza espiritual um ato muito mais importante que a limpeza corporal, isso gerou o mito de que as termas romanas eram lugares de orgias e depravações. Ainda que em muitas cidades européias na idade média possuíam banhos públicos, esses lugares eram vistos como de má reputação e deviam ser evitados, segundo a opinião de São Jerônimo (Epístola 45.5), um atentado contra a castidade. Com isso a maioria das cidades deste período abriram mão das águas correntes e do sistema de banhos públicos, dando lugar à pestilência e péssimos costumes de higiene corporal, o que tornou a Europa a uma fonte significativa de pestes e doenças como peste bubônica, difteria, cólera e disseminação de animais peçonhentos como pulgas, carrapatos, sarna entre outros. Na Europa setentrional, de clima mais frio, a igreja cristã passou a considerar a limpeza excessiva como algo insano e frívolo, passível de reprovação.

Durante a reforma protestante do século XVI, a situação se agravou ainda mais, levando a higiene pessoal quase às raias da proibição, sendo comum nas cortes européias nobres vangloriarem-se de haverem se banhado apenas duas ou três vezes em toda a sua vida (afirmam muitos historiadores que D. João VI, rei de Portugal e regente do Brasil, tomou apenas dois banhos em sua vida, o primeiro 
em sua coroação e o segundo em seu casamento com princesa espanhola Carlota Joaquina, nobre da corte Espanhola).

Após o período medieval, a Igreja reformulou sua posição, passando o clero a organizar peregrinações, sobretudo na França, o que resultou na abertura de estabelecimentos termais sob sua dependência (TAILLEUX, 1991; AMIROU, 1995).

Durante os séculos XVIII e XIX, houve uma retomada da cultura clássica e com isso o surgimento de um modismo que perdura até os nossos dias, que é o consumo de águas minerais e termo-minerais, tanto para ingestão como para banhos medicinais; com isso balneários como o Bath, da Inglaterra, Vichy, na França, Baden-Baden, na Alemanha, Saratoga Springs, nos E.U.A e La Toja, na Espanha entre muitos outros, tornaram-se famosos e atraem milhares de pessoas todos os anos, gerando cifras milionárias.

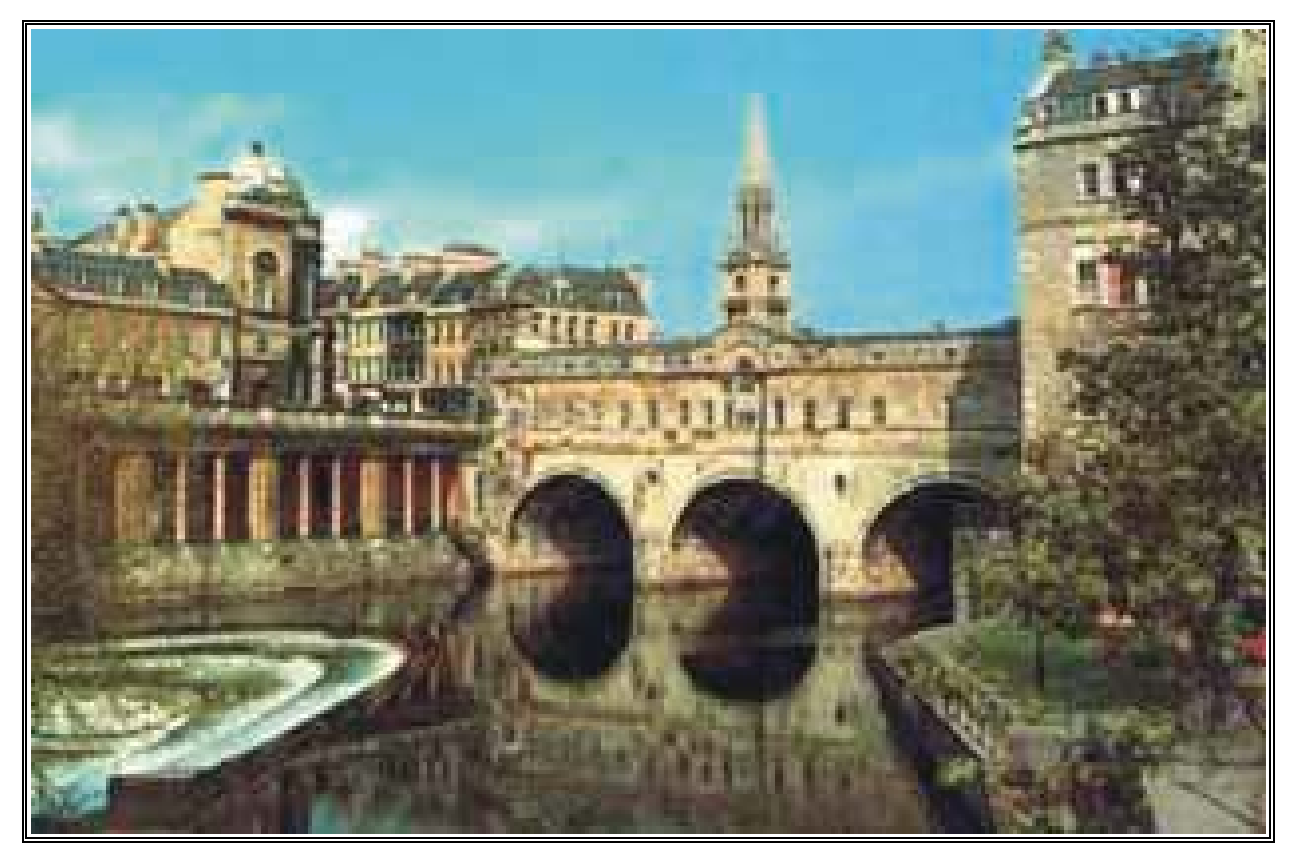

Foto 1.6 - Termas de Bath - Inglaterra (Fonte: http://www.imagensviagens.com/bath.htm)

Na primeira metade do século XIX, embora a clientela termal na Europa fosse reduzida em número, a freqüência era ainda predominantemente aristocrática (GERBOD, 1983). As águas termais eram procuradas na expectativa de se obter uma cura, um milagre; eram também reputadas como milagrosas, 
construindo-se socialmente as estâncias de cura e repouso. A expressão ir a curas deriva do termo alemão "Kure" (WALLON, 1981), que, na língua portuguesa, originou a palavra "curista", usado em Portugal para definir aquele que utilizava os tratamentos termais.

Segundo WALLON (op. cit.), o termo também era utilizado na França, sobretudo a partir de 1910, pois até esta época a denominação mais freqüente era "aller aux eaux", correspondente à expressão portuguesa "ir a águas".

Segundo SANTOS (1986), no século XVI já era conhecido o grau geotérmico da terra em medições feitas em minas subterrâneas, e que a temperatura subia quando a profundidade aumentava. Este fluxo de calor só foi determinado pela primeira vez pelo cientista inglês Willian Thonson (1824 - 1907), também conhecido como Lord Kelvin, que encontrou o valor de $68 \times 10^{-3} \mathrm{~W} / \mathrm{m}^{2}$ estudando a temperatura de minas de carvão.

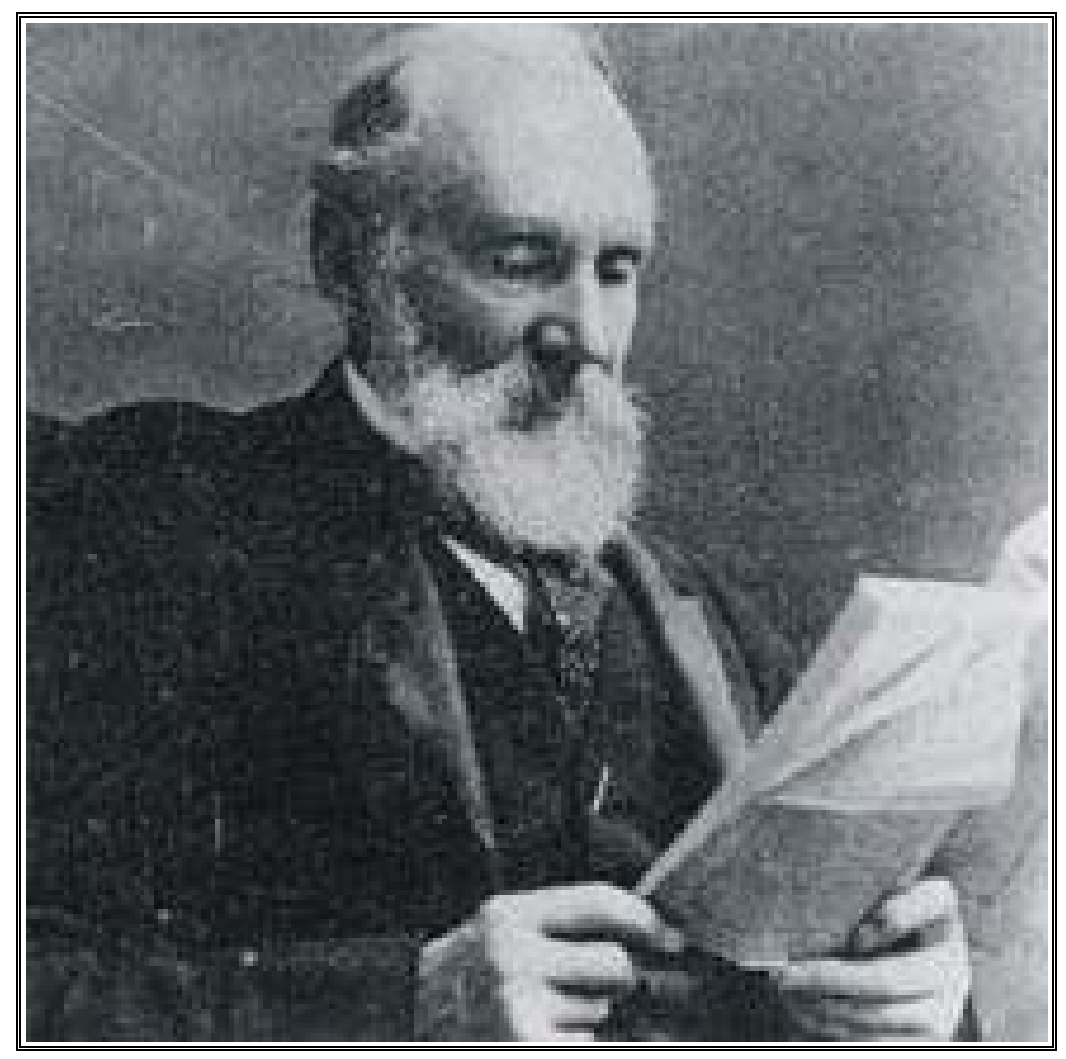

Foto 1.7 - Lord Willian Thonson Kelvin (1824-1907) (fonte: http://scienceworld.wolfram.com/biography/Kelvin.html) 
O Estado de Santa Catarina, apesar do pioneirismo no Brasil em relação às suas águas termais e termo-minerais, não apresenta um histórico de grande explotação e exploração destes recursos, ou mesmo a existência de planos de gestão para esses recursos, resultando em uma exploração pouco produtiva das várias estâncias termais, entre elas as termas mais antigas do Brasil, as de Caldas da Imperatriz em Santo Amaro da Imperatriz, datadas de meados do século XIX.

Não existem pesquisas aprofundadas sobre a gênese dessas águas e nenhum panorama sócio-econômico foi montado em função da exploração destas águas termais e termo-minerais para o seu melhor aproveitamento. 


\section{2 - OBJETIVO}

O objetivo deste trabalho foi montar um panorama das ocorrências termais e termo-minerais da região centro-sul da Borda oriental do estado de Santa Catarina, dando um enfoque para os possíveis modelos genéticos e lançar novos dados sobre o potencial sócio-econômico para os municípios que contém essas fontes. 


\section{3 - METODOLOGIA}

Foram analisadas dentro das gêneses dessas ocorrências os possíveis modelos hidrogeológicos e hidrogeoquímicos das surgências e captações por poços tubulares profundos ou caixas de captação, aplicáveis na região centrosul da Borda oriental do Estado de Santa Catarina, principal concentração deste tipo de ocorrência no estado.

As questões levantadas sobre o potencial sócio-econômico do ponto de vista regional e estadual, foram analisadas dentro das possibilidades de balneabilidade e envase versus oferta de água, e o impacto sócio-econômico para as comunidades que utilizam essas águas, bem como o incremento gerado na forma de empregos, comércio e bem-estar social. Também foram analisadas as tendências de crescimento no setor de águas envasadas e balneoterapia para o estado de Santa Catarina.

Para este trabalho foi necessário obter, identificar e caracterizar a partir do ponto de vista hidrogeológico e hidrogeoquímicos as surgências e captações de águas subterrâneas na região estudada, tentando ao mesmo tempo analisar seu potencial de explotação e estabelecer possíveis correlações entre esses aqüiferos e sua gênese termal.

\section{1 - Bibliografia de apoio}

A revisão bibliográfica possibilitou levantar o atual estágio de conhecimento das unidades que compõem o trato rochoso da região em que está inserida a área estudada, no que se refere aos conhecimentos das características e particularidades da hidrogeologia, estratigrafia, litologia e dos aspectos morfoestruturais, além da qualidade físico-químico e dos diversos usos das águas subterrâneas que ocorrem na área.

O trabalho foi embasado em publicações já consagradas na geologia catarinense entre elas resumos, informes, papers, projetos e mapeamentos realizados em todo o estado, principalmente nas décadas de 70 e 80 
e mais raramente de autores da década de 90 e início do século XXI. Como bibliografia mais específica foram consultados trabalhos da década de 80 do século XX, da comissão de Geotermia do IPT - Instituto de Pesquisas Tecnológicas e do ON - Observatório Nacional.

Como material auxiliar foram analisados textos de autores estrangeiros em trabalhos feitos na América do Norte e Europa , tirados de livros, mas principalmente de sítios na internet de instituições de renome na geologia e hidrogeologia mundiais. Igualmente foram utilizadas para o melhor entendimento da geologia regional e local as seguintes publicações :

- DNPM / CPRM "Geologia da Quadrícula de Laguna" - Folha de Laguna, escala 1:250.000 (1969);

- DNPM / CPRM "Geologia da Quadrícula de Florianópolis" - Folha de Florianópolis, escala 1:250.000 (1970).

- DNPM

"Mapeamento da Ilha de Florianópolis" - Folha de Florianópolis, escala 1:50.000 (1970);

- DNPM / CPRM "Projeto Carta Geológica do Brasil ao Milionésimo" Folha SH.22, Porto Alegre (1974).

- DNPM / CPRM "Projeto Mapas Metalogenéticos e de Previsão de Recursos Minerais" - Folha de Florianópolis, escala $1: 250.000$ (1983).

- DNPM / CPRM "Projeto Levantamentos Geológicos Básicos do Brasil Carta Geológica" - Folha de Criciúma, SG.22-X-B, escala 1:250.000 (2000).

- DNPM / CPRM "Projeto Levantamentos Geológicos Básicos do Brasil Carta Hidrogeológica" - Folha de Criciúma, SG.22-X-B, escala 1:250.000 (2000).

- DNPM / CPRM "Projeto Levantamentos Geológicos Básicos do Brasil Mapa metalogenético “- Folha de Criciúma, SG.22-X-B, escala 1:250.000 (2000).

- IBGE "Carta do Brasil - Escala 1:50.000" Folha de Rancho Queimado - SG-22-Z-D-IV-2. 1999 (Revisão da carta de 1974) 
- IBGE

- IBGE

- IBGE

- IBGE

- IBGE

- IBGE

- IBGE

- IBGE

- IBGE

- IBGE

- IBGE
"Carta do Brasil - Escala 1:50.000" Folha de Santo Amaro da Imperatriz - SG-22-Z-D-V-1 1999 (Revisão da carta de 1974)

"Carta do Brasil - Escala 1:50.000" Folha de Florianópolis - SG-22-Z-D-V-2 1999 (Revisão da carta de 1976)

"Carta do Brasil - Escala 1:50.000" Folha de Anitápolis

- SG-22-Z-D-IV-4 1999 (Revisão da carta de 1976)

"Carta do Brasil - Escala 1:50.000" Folha de São Bonifácio - SG-22-Z-D-V-3 1999 (Revisão da carta de 1974)

"Carta do Brasil - Escala 1:50.000" Folha de Paulo Lopes - SG-22-Z-D-V-4/VI-3 1999 (Revisão da carta de 1976)

"Carta do Brasil - Escala 1:50.000" Folha de Grão Pará - SG-22-X-B-I-2 1999 (Revisão da carta de 1976)

"Carta do Brasil - Escala 1:50.000" Folha de São Martinho SG-22-X-B-II-1 1999 (Revisão da carta de 1976)

"Carta do Brasil - Escala 1:50.000" Folha de Imbituba SG-22-X-B-II-2 1999 (Revisão da carta de 1976)

"Carta do Brasil - Escala 1:50.000" Folha de Tubarão SG-22-H-B-I-4 1999 (Revisão da carta de 1976)

"Carta do Brasil - Escala 1:50.000" Folha de Laguna SG-22-X-B-II-3 1999 (Revisão da carta de 1977)

"Carta do Brasil - Escala 1:50.000" Folha de Vila Nova SG-22-X-B-II-4 1999 (Revisão da carta de 1976) 


\section{2 - Coleta e apresentação dos dados}

\subsection{1 - Inventário das Fontes Termais}

Esta parte do trabalho se inicia com o desenho de uma tabela cadastral (Anexo 01) específica para águas do tipo termal e termo-mineral, pois quantifica e compara parâmetros físico-químicos entre as diferentes fontes, para refletir todas as características do sistema de captação, da água em si, e do contexto hidrogeológico onde se encontram localizadas. Também constam no inventário coordenadas UTM das ocorrências que posteriormente foram plotadas em um mapa de localização e geológico. Estes dados foram dispostos na forma de uma tabela única para facilitar a consulta dos dados e permite comparações entre eles. Como base de dados foram utilizadas duas publicações e vários relatórios finais de pesquisa de algumas das áreas estudadas.

Entre as obras utilizadas temos:

- Águas Minerais de Santa Catarina, publicado pelo Departamento Nacional da Produção Mineral - DNPM, (ÁVILA et al. 1986)

- Águas Minerais de Santa Catarina, Tese de mestrado, COBRAC 2000 - Congresso Brasileiro de Cadastro Técnico Multifinalitário · UFSC Florianópolis. (COITINHO, 2000)

- Relatório final de pesquisa Processo 2.360/ 1942

- Relatório final de pesquisa Processo 809.746/1972;

- Relatório final de pesquisa Processo 815.374/ 1985;

- Relatório final de pesquisa Processo 815.174/1991;

- Relatório final de pesquisa Processo 815.372/1992;

- Relatório final de pesquisa Processo 815.153/2001

- Relatório final de pesquisa Processo 815.213/ 2002

- Avaliação Hidrogeológica do manancial subterrâneo que abastece o Complexo Turístico Águas Mornas Palace Hotel - Município de Águas Mornas (BORGES, 1994) 
A escolha das fontes seguiu alguns critérios de seleção, como segue abaixo:

- Se a Fonte/surgência ou Poço tubular profundo estão devidamente cadastrada no DNPM;

- Se existe alguma análise físico-química oficial (Laboratório de Análises Minerais - LAMIN / Companhia de Pesquisa de Recursos Minerais CPRM) ou feita em laboratórios idôneos;

\subsection{2 - Trabalhos de campo}

Os trabalhos de campo iniciaram-se em escritório com a pesquisa de Referências bibliográficas de pesquisas anteriores efetuadas nas regiões próximas a área e a elaboração do plano de viagem, coleta de dados fisiográficos relativos a clima, geomorfologia, solo, vegetação, entre outros; definição de vias de acessos principais e secundárias e referências cartográficas.

Iniciaram-se efetivamente, os trabalhos de campo com a montagem do acervo fotográfico, onde foram registradas várias etapas da evolução da pesquisa e início da confecção do trabalho de coleta de dados. Nesta etapa foram percorridas algumas áreas, descritas as litologias mais significativas e analisados os sistemas de fraturamento destas rochas, bem como sua relação com a geomorfologia e grau de alteração.

Para a elaboração do trabalho foram realizadas sete campanhas distintas no campo: três delas de caráter regional, visando definir os limites da poligonal; duas para a coleta de dados geológicos; outra de caráter mais localizado, objetivando definir através de um prévio levantamento com GPS (Global Positioning System - Sistema de Posicionamento Global), a localização de algumas surgências e poços e uma última saída de campo para analisar a tectônica regional.

O levantamento cadastral das surgências foi executado com GPS, modelo GARMIM 76s, com elipsóide de referência (DATUM) SAD 69 (Com a utilização deste sistema, torna-se conveniente transformar os dados quando se deseja trabalhar em outro sistema geodésico como é o caso do SAD-69 (South America Datum de 1969) ou ainda o nacional Córrego Alegre Datum. Estes dois 
sistemas são usados no Brasil, sendo o Córrego Alegre adotado nas cartas do DSG (Diretoria de Serviço Geográfico) e o SAD-69 utilizado pelo IBGE (Instituto Brasileiro de Geografia e Estatística), referenciado com o norte verdadeiro e o sistema métrico internacional, operando com código C/A e deturpação de sinal S/A com precisão média de $6 \mathrm{~m}$ a partir do ponto de registro e Estação Total.

O GPS é um sistema multipropósitos, que permite aos usuários determinar suas posições expressa em latitude, longitude e altura geométrica ou elipsoidal em função das coordenadas cartesianas $X, Y$ e $Z$ em relação ao centro de massa da terra. A antena detecta as ondas eletromagnéticas emitidas pelos satélites, converte a energia da onda em corrente elétrica, amplifica o sinal e o envia para a parte eletrônica do receptor. Em razão do tipo de sinal GPS e de sua estrutura, todas as antenas devem ser polarizadas circularmente à direita (RHCPRigth-Hand Circularly Polarised). A antena deve ter boa sensibilidade para receber sinais mais fracos e ainda receber sinais em todas as elevações e azimutes.

Para a análise da geologia e a inter-relação entre camadas neste trabalho, foram utilizadas duas colunas estratigráficas definidas por diferentes autores, pois a área do trabalho é bastante extensa. Foram utilizadas as colunas definidas por SILVA (1987) e ZANINI (1997).

\subsection{3 - Caracterização Físico-química das Fontes Termais}

As análises utilizadas neste estudo foram em sua maioria feitas pelo Laboratório de Análises Minerais - LAMIN / Serviço Geológico do Brasil - CPRM / Instituto de Pesquisas Tecnológicas - IPT, e encontram-se anexados aos Relatórios finais de pesquisa. Também foram utilizadas análises feitas pelos próprios titulares dos processos de pesquisa, em laboratórios privados porém de idoneidade assegurada pelas normas do Conselho Regional de Química - CRQ.

Em linhas gerais cabe ressaltar que houve um predomínio de águas fluoretadas com radioatividade mediana, com resíduos de evaporação a seco na ordem de $70 \mathrm{mg} / \ell$. 


\subsection{4 - Estudos Técnico-Econômicos}

O estudo técnico-econômico das atividades industriais relacionadas com as águas termais e termo-minerais foi realizado a partir de trabalhos ligados a área de desenvolvimento econômico das regiões analisadas e de dados técnicos de reserva, volume explotado e oferta feitas pelo DNPM em anuários minerais.

O ideal seria elaborar um questionário com perguntas relacionadas ao perfil do consumidor em todas as diferentes formas de exploração das águas termais e termo-minerais, como envase, balneário e crenoterapias. Devido a grande procura por este tipo de ocorrência em Santa Catarina, coletar dados desta natureza é bastante difícil, posto que os titulares de processos de água mineral dificilmente liberam dados oficiais de suas áreas. 


\section{4 - LEGISLAÇÃO E CLASSIFICAÇÃO DAS FONTES TERMAIS E TERMO- MINERAIS}

A lei no Brasil que define e versa sobre as águas termais e termominerais é o Decreto-LEI № 7.841, de 08 de agosto de 1945, de onde foram extraídos os seguintes trechos relevantes:

- CAPÍTULO I - Disposições Preliminares.

- Art. $1^{\circ}$ - Águas minerais são aquelas provenientes de fontes naturais ou de fontes artificialmente captadas que possuam composição química ou propriedades físicas ou físico-químicas distintas das águas comuns, com características que lhes confiram uma ação medicamentosa.

- CAPÍTULO VIII - Da Classificação das Fontes de Água Mineral.

○ $2^{\circ}$ ) Quanto à Temperatura

- Fontes frias, quando sua temperatura for inferior a $25^{\circ} \mathrm{C}$;

- Fontes hipotermais, quando sua temperatura estiver compreendida entre $25^{\circ} \mathrm{C}$ e $33^{\circ} \mathrm{C}$;

- Fontes mesotermais, quando sua temperatura estiver compreendida entre $33^{\circ} \mathrm{C}$ e $36^{\circ} \mathrm{C}$;

- Fontes isotermais, quando sua temperatura estiver compreendida entre $36^{\circ} \mathrm{C}$ e $38^{\circ} \mathrm{C}$;

- Fontes hipertermais, quando sua temperatura for superior a 38 ${ }^{\circ} \mathrm{C}$. 
- capítulo VIII

- Art. 36 - As fontes de água mineral serão classificadas, além do critério químico, pelo seguinte:

$1^{\circ}$ - Quanto aos Gases:

- Fontes radioativas:

- fracamente radioativas, as que apresentarem, no mínimo, uma vazão gasosa de 1 litro por minuto (1 l.p.m) com um teor em radônio compreendido entre 5 e 10 unidades Mache, por litro de gás espontâneo, a $20^{\circ} \mathrm{C}$ e $760 \mathrm{~mm}$ de $\mathrm{Hg}$ de pressão;

- radioativas, as que apresentarem, no mínimo, uma vazão gasosa de 1 l.p.m., com um teor compreendido entre 10 e 50 unidades Mache, por litro de gás espontâneo, a $20{ }^{\circ} \mathrm{C}$ e 760 mm de $\mathrm{Hg}$ de pressão;

- fortemente radioativas, as que apresentarem, no mínimo, uma vazão gasosa de 1 l.p.m., com teor em radônio superior a 50 unidades Mache, por litro de gás espontâneo, a $20^{\circ} \mathrm{C}$ e 760 mm de $\mathrm{Hg}$ de pressão. 


\section{5 - CARACTERIZAÇÃO DA GEOLOGIA REGIONAL E DA ÁREA DE PESQUISA}

Neste capítulo serão descritas apenas as unidades da qual se inserem os registros de fontes termais e termo-minerais na região de estudo, evitando-se assim alongar-se em um assunto que será melhor descrito no capítulo sobre a geologia local.

A geologia da região centro-sul oriental do Estado de Santa Catarina é bastante diversificada com porções aflorantes do Escudo Catarinense a leste e coberturas Fanerozóicas da Bacia do Paraná a Oeste. Pode-se dizer que a compartimentação tectônica para a porção meridional da província Mantiqueira envolve duas unidades tectônicas importantes, o Cráton Rio de La Plata e o Cinturão Dom Feliciano.

\section{1 - Histórico}

O primeiro reconhecimento geológico sobre os terrenos précambrianos do Estado de Santa Catarina deve-se a DUTRA (1926).

Em 1938, Carvalho \& Pinto, publicaram o primeiro mapa geológico regional abrangendo o leste catarinense, incluindo também a ilha de Santa Catarina, empregando a designação "Complexo Brasileiro" para reunir o conjunto de rochas granito-migmatíticas dessa faixa.

ALMEIDA (1948), já reconhecera os granitos componentes desta unidade, como intrusivos em gnaisses. TEIXEIRA (1969a), que inicialmente, descrevera estas litologias como "Complexo Granítico de Santa Catarina, depois "Complexo Granítico Pedras Grandes", ao mapear áreas logo a sul da Folha de Curitiba, englobou as rochas graníticas em geral.

TEIXEIRA et alli (1969b), realizaram datações radiométricas obtendo idades absolutas dentro de uma mesma faixa de grandeza, que vai de 445 m.a a 566 m.a.

SCHULZ JR. et alli (1970), mapeando a Quadrícula de Florianópolis, subdividiram o "Complexo Granítico Pedras Grandes" de TEIXEIRA (1969a) em 
quatro fácies graníticas: Imaruí, Rio Chicão, Jaguaruna e Palmeira do Meio. A caracterização em fácies é decorrência das rochas apresentarem variações de granulação, textura e coloração, constituindo um todo, praticamente homogêneo em composição, sendo conspícuas as gradações entre os diversos tipos e até subjetivas as delimitações entre os mesmos.

WILLIG et alli (1972), denominaram as rochas graníticas ocorrentes na região leste de Santa Catarina e que mostram características intrusivas, tanto nos migmatitos e rochas associadas ao Grupo Tabuleiro, como Grupo Pedras Grandes.

HORBACH \& MARIMON (1982), originalmente incluídos por TRAININI et alli (op. cit) na Suíte Intrusiva Pedras Grandes, estes corpos estão agrupados, em trabalhos de cunho regional, por KAUL et alli (1976) na "Suíte Intrusiva Valsungana", caracterizados por granitos porfiríticos polidiapíricos, destes autores, tidos como sintectônicos a tarditectônicos e parauctóctonos a alóctonos".

MORGENTAL \& KIRCHNER (1983), pelas características mineralógicas, consideram que as rochas que compõem o trato rochoso na região de Tubarão (ao sul da área de pesquisa) é a Suíte Intrusiva Guabiruba, constituída por rochas graníticas pós-tectônicas.

SILVA (1987), "denomina Suíte Intrusiva Pedras Grandes, redefinida a partir da sua conceituação original: Complexo Pedras Grandes (CASTRO \& CASTRO, 1969) e parte do Complexo Tabuleiro (SCHULZ \& ALBUQUERQUE,1969), desconsiderando-se as inúmeras e pouco claras conotações que Ihes foram atribuídas nos diversos trabalhos posteriores".

ZANINI (1997), à luz de novos dados disponíveis, verificou que na Faixa Granito-Gnáissica Santa Rosa de Lima/Tijucas, ocorrem rochas tonalíticas e dioríticas deformadas, em seu trabalho incluídas no Complexo Águas Mornas, denominação informal dada ao Complexo Granito-Gnáissico, bem como exposições de tonalitos e rochas afins mais jovens, que foram relacionadas a granitóides da Suíte Intrusiva Maruim. 


\section{2 - Arqueano / Proterozóico Inferior}

\subsection{1 - Complexo Tabuleiro}

Por sua própria natureza petrotectônica é uma das unidades que apresenta a maior diversidade petrográfica e estrutural. É constituído por complexos gnáissicos-graníticos, polifásicos envolvidos de uma forma ou de outra nos processos de deformação regional, especialmente, aqueles relacionados a fenômenos de cizalhamento dúctil bem como injeção de magmas granitóides, que afetaram uma ampla extensão do Estudo Catarinense.

A abordagem litoestratigráfica do complexo tabuleiro adotada no presente texto (SILVA, 1987), segue com algumas alterações a proposição apresentada nos trabalhos do mesmo autor em 1984. A partir destes critérios, o complexo foi subdividido em seis unidades informais, quatro das quais constituídas por associações granito-gnáissicas (faixas) e duas representando núcleos migmatíticos de injeção polifásica.

\subsection{2 - Complexo Águas Mornas}

O Complexo Águas Mornas corresponde a uma faixa descontínua de granitóides deformados, com freqüentes estruturas gnáissicas, localmente migmatíticas, correspondendo, em parte, ao que SCHULTZ Jr. et alli (1969) pioneiramente designaram de Grupo Tabuleiro.

TRAININI et alli (1978) substituíram a denominação de Grupo Tabuleiro por Complexo Metamórfico-Migmático, incluindo sob tal denominação "...todo conjunto de variada composição petrográfica que encerra rochas de idade pré-cambriana superior e aquelas mais antigas, rejuvenescidas durante o Ciclo Brasiliano" , que dividiram em duas unidades: Metatexitos e Diatexitos.

HARTMAN et alli (1979) restringiram a designação de Complexo Metamórfico-Migmático às rochas metamórficas da porção meridional do Escudo Catarinense, diferenciando-as das rochas de alto grau ocorrentes ao norte, as quais reuniram no Complexo Granulítico de Santa Catarina. 
SILVA (1986) manteve a divisão proposta por HARTMAN et alli (op. cit.) e retomou o termo Tabuleiro de SCHULTZ Jr. et alli (op. cit.) como Complexo Tabuleiro.

\subsubsection{1- Faixa Granito-Gnáissica Santa Rosa de Lima/ Tijucas}

Segundo SILVA \& BORTOLUZZI (1987), a Faixa Granito-Gnáissica Santa Rosa de Lima/Tijucas é a que apresenta maior área de ocorrência (2.000 $\mathrm{Km} 2$ ). Estende-se de maneira contínua por cerca de $150 \mathrm{Km}$, a sua largura média aflorante situa-se em torno de $10 \mathrm{Km}$, e a máxima, em torno de $35 \mathrm{Km}$ entre os municípios de Anitápolis e São Bonifácio, aflorante em todo o vale dos rios Povoamento e do Meio, a oeste da cidade de Anitápolis e por cerca de $20 \mathrm{Km}$ no vale do Rio Cubatão, entre as localidades de Queçaba e Santo Amaro da Imperatriz.

A faixa em toda sua extensão oriental limita-se com a Suíte Intrusiva Pedras Grandes e Complexo Metamórfico Brusque, sendo que na extremidade ocidental acha-se coberta pelos depósitos da Bacia do Paraná. Seu limite norte dáse com o Cinturão Brusque.

\subsubsection{Faixa Granito-Gnáissica Garopaba}

Segundo SILVA \& BORTOLUZZI (op. cit.), esta faixa é constituída por uma série de pequenos corpos de comprimento atingindo poucos quilômetros, que se distribuem entre as localidades de Paulo Lopes e Garopaba, incluindo o denominado Granito Balsinha de CASTRO \& CASTRO (1969), e restos do Grupo Tabuleiro.

\section{3 - Mesoproterozóico / Eopaleozóico}

\subsection{1 - Grupo Itajaí}

O conjunto de associações vulcano-sedimentares das coberturas subhorizontais de plataforma são aqui agrupadas, segundo SILVA \& BORTOLUZZI (op. Cit.), formalmente sob a designação de Grupo Itajaí . Estas associações ocorrem 
em quatro "bacias" isoladas, cujos limites atuais acham-se afastados por dezenas de quilômetros.

São ainda considerados como pertencentes a presente unidade, diversos corpos isolados de vulcanitos félsicos ou, de rochas piroclásticas, distribuídos especialmente na região centro-leste, entre as localidades de Queçaba e a llha de Santa Catarina.

\subsubsection{1 - Formação Campo Alegre}

Nas citações de SILVA \& BORTOLUZZI (op. cit.), os depósitos do centro da bacia (de topo e não base) são de granulometria mais fina, caracteristicamente de coloração esverdeada, relacionados a paleoambientes redutores, não raro exibindo contatos gradacionais com os psamitos da Formação Gaspar sotoposta. Contribuições de rochas vulcanoclásticas podem ser localmente observadas, enquanto que vulcanismo e sub-vulcanismo de caráter ácido, materializado sob a forma de diversos "stocks" têm expressiva presença na extremidade sudoeste da bacia associado ao qual ocorre um corpo de granito alcalino (granito Subida).

A principal característica desta formação são os espessos depósitos turbidíticos aflorantes nas margens do Rio Itajaí-Açu, junto a rodovia federal $\mathrm{Br}$ 470.

A interveniência de processos decorrente de turbidez foi pela primeira vez invocada no trabalho de SILVA \& DIAS (1981), para explicar a sucessão cíclica entre finos estratos pelíticos e psamíticos. Citam também, a ocorrência de horizontes tufáceos de composição félsica, com espessura máxima de $3 \mathrm{~m}$.

SCHULZ Jr. \& ALBUQUERQUE (1969), por sua vez, já mencionavam a existência de lavas riolíticas relacionadas a atual Formação Campo Alegre. 


\section{4 - Eo-Paleozóico}

\subsection{1 - Suíte Intrusiva Subida}

No sentido aqui proposto por SILVA \& BORTOLUZZI (op. Cit.), a Suíte Subida inclui seis corpos de granitóides especialmente alojados nos gnaisses de alto grau do Complexo Granulítico de Santa Catarina, três dos quais - Subida, Corupá e Serra Alta - são também relacionadas espacial e geneticamente à seqüência vulcano-sedimentar de cobertura do Grupo Itajaí, mais especificamente, à Formação Campo Alegre.

Constituem "stocks" com formas e expressões aflorantes variáveis. As dimensões variam desde $5 \mathrm{Km}^{2}$ (Serra Alta) ; $20 \mathrm{Km}^{2}$ (Dona Francisca e Piraí) ; $60 \mathrm{Km} 2$ (Corupá) ; $70 \mathrm{Km} 2$ (Subida). Apenas o corpo mais setentrional (Morro Redondo), que tem continuidade no Estado do Paraná, apresenta dimensões batolíticas, mesmo em território catarinense. São corpos caracteristicamente circunscritos, de contatos intrusivos, quer concordantes, quer discordantes com as encaixantes de alto grau ou com a seqüência terrígena do Grupo Itajaí, por exemplo, o Granito Subida desenvolve uma auréola de contato de aproximadamente $100 \mathrm{~m}$ de espessura onde os pelitos encontram-se transformados em "ardósias maculosas" (SCHULZ Jr. \& ALBUQUERQUE, 1969; KAUL, 1976).

Já as relações de contato com os vulcanitos do mesmo Grupo Itajaí são "dúbias, às vezes contraditórias" com seções onde o granitóide intrusiona-se nos mesmos e, em outras, é cortado por corpos filonianos da seqüência efusiva (DAITX 1979).

Caracterização petrográfica -são leucogranitos, com composição sienogranítica, em geral alaskíticos, de coloração avermelhada e marrom; textura granular hipidiomórfica média a grosseira, isótropos e homogêneos. Apresentam freqüentemente variedades "hipersolvus", ou mesmo sieníticas como em Corupá.

Além da biotita e hornblenda apresentam via de regra, uma associação diversificada de piroxênios e anfibólitos sódicos, que lhes confere um 
caráter per-alcalino: riebeckita, aegirina-augita, barkevikita, arfvedsonita, titanoaugita, ferrohastingsita.

A origem dos magmas geradores desses granitóides poderia relacionar-se à fusão crustal em zonas profundas. A natureza do material fonte, neste caso, deveria ser procurada possivelmente a partir das rochas granulíticas, embora por falta de tratamento litogeoquímico, uma origem mantélica a partir da cristalização fracionada de um magma juvenil, não possa ser descartada, especialmente em função das baixas razões isotópicas iniciais.

Trata-se possivelmente de um evento intraplaca de natureza cratogênea sugerido desde o trabalho de SILVA \& DIAS (1981) e mais tarde aceito por diversos trabalhos posteriores (KAUL et alli 1982).

Quanto aos depósitos de encosta, estes podem estar representados pelos depósitos rudáceos formados por pedimentação.

\subsubsection{1 - Suíte Intrusiva Pedras Grandes}

TEIXEIRA (1969) denominou de "Complexo Granulítico Pedras Grandes", um conjunto de rochas graníticas de composição homogênea, com variação textural de granulação e cor. Através de análises químicas e observações das relações de contato foi sugerido por SILVA (1987), o uso de Suíte Intrusiva Pedras Grandes para o conjunto de rochas graníticas de quimismo alcalino de composição predominantemente similar, com blastese desenvolvida, que gradam para o complexo metamórfico migmatítico.

A Suíte Intrusiva Pedras Grandes, unidade litoestratigráfica foi aqui redefinida por SILVA (op. cit.), a partir de sua conceituação original: Complexo Pedras Grandes (CASTRO \& CASTRO, 1969) e a partir do Complexo Tabuleiro (SCHULTZ Jr. e ALBUQUERQUE, 1969), desconsiderando as inúmeras e pouco claras conotações que lhe foram sendo atribuídas nos diversos trabalhos posteriores. 


\section{5 - Paleozóico Inferior-médio}

\subsubsection{Formação Rio do Sul}

LOCZY (1964) introduziu o termo Rio do Sul na literatura geológica para denominar os arenitos que ocorrem próximos a cidade homônima, em Santa Catarina, correlacionando-os ao Grupo Itararé.

A porção mais inferior da formação em Santa Catarina é constituída de folhelhos e argilitos cinza-escuros a pretos, localmente com aspecto várvico, designados de folhelhos Lontras. Seguem-se diamictitos acinzentados, escuros, com matriz arenosa, que gradam ou intercalam-se com arenitos finos a muito finos, que por sua vez é recoberto por folhelhos, freqüentemente várvicos, ritmitos e argilitos, cinza-escuros a avermelhados, às vezes com laminação "flaser".

\section{6 - Paleozóico Superior / Mesozóico}

\subsubsection{Formação Irati}

Definida por WHITE (1908) para nomear os folhelhos pretos com restos de répteis Mesossaurus brasiliensis que ocorrem persistentemente nos Estados de São Paulo, Paraná e Santa Catarina até o Rio Grande do Sul.

Em Santa Catarina a formação costuma ser subdividida em dois membros: Taquaral e Assistência. O Membro Taquaral consiste de siltitos e folhelhos cinza escuros, eventualmente cinza claros e azulados, com desagregação conchoidal.

Segundo MÜHLMANN et alli (1974), as características litológicas e sedimentares desta unidade são indicativas de ambiente marinho de águas calmas, abaixo do nível de ação das ondas.

A designação Membro Assistência é empregada para o pacote de folhelhos cinza escuros que intercala, em geral, camadas de folhelhos pretos, pirobetuminosos, associados a horizontes de calcários de coloração creme a cinza 
escuros, dolomíticos, silicificados em superfície, sendo característica em Santa Catarina a formação de nódulos de sílex.

Sua gênese é dita como marinha de águas rasas, com os folhelhos pirobetuminosos sedimentares em ambiente de restrição, enquanto os calcários terse-iam desenvolvido em áreas de plataforma.

Os contatos da Formação Irati, superior e inferior, são concordantes com as formações Serra Alta e Palermo, respectivamente, da mesma forma, que é concordante o contato entre os membros Taquaral e Assistência.

PETRI \& FÚLVARO (1983), salientam que existem ponderáveis postulações contra um ambiente marinho normal, como ausência de fósseis marinhos, enquanto que, em contrapartida, são abundantes as formas suceptíveis de viver em água doce, como os répteis e crustáceos, além das formas vegetais associadas. Em vista disto, sugerem um ambiente lagunar para a sedimentação do Irati.

\subsubsection{Formação Serra Alta}

Compreende uma seqüência de folhelhos, argilitos e siltitos cinza escuros a pretos, com fratura conchoidal, situados acima da camada superior de folhelho betuminoso da Formação Irati. Localmente desenvolvem-se lentes e concreções calcíferas. Embora originalmente o termo tenha sido proposto na categoria de Membro da Formação Estrada Nova (GORDON Jr., 1947), ele tem sido usado mais comumente sob a denominação de fácies ou de formação.

Sua ocorrência em Santa Catarina é extensiva a praticamente toda a faixa de afloramentos da seqüência gonduânica, desaparecendo apenas na região sul, a partir aproximadamente da latitude da cidade de Meleiro. As principais exposições estão presentes ao longo da estrada Rio do Sul - Lages, onde a formação foi descrita, em outros locais dos municípios de Lages e Rio do Sul e amplo trecho da estrada Alfredo Wagner - Bom Retiro. 


\subsubsection{Formação Terezina}

É formada por argilitos cinza-escuros a esverdeados ritmicamente intercalados com siltitos cinza-escuros, róseos a avermelhados quando alterados, entremeando camadas ou lentes de calcários, às vezes oolíticos e silicificados. A laminação "flaser" é característica desta formação, com alternância de folhelhos com siltitos e arenitos muito finos, além da laminação ondulada, microlaminação cruzada, fendas de contração (ressecamento), marcas ondulares e diques de arenito.

\subsubsection{Formação Rio do Rasto}

WHITE (op. cit.) foi o primeiro a dar este nome a sucessão de camadas vermelhas expostas nas cabeceiras do Rio do Rasto, na estrada Lauro Müller - São Joaquim, descrevendo-as como segue:

"Nos shistos de Palermo, Iraty e Estrada Nova, ocorrem ocasionalmente estratos vermelhos, cor de púrpura ou castanhos, mas eles são sempre de pequena espessura que podem ser devidos em muitos casos a causas secundárias que agiram subseqüentemente ao depósito mas, passando acima do horizonte do Calcáreo Rocinha, as rochas tornaram-se bruscamente de uma cor vermelhaescura e muitas vezes variegadas, com manchas esbranquiçadas de 5 a $30 \mathrm{~cm}$ ou mais de diâmetro, ao passo que ao mesmo tempo "grés" espessos e conglomerados inconsolidados. “

A seqüência deposicional da Formação Rio do Rasto, a deduzir-se pela coloração de seus sedimentos, revela uma condição progressivamente mais oxidante do ambiente de sedimentação com a passagem das condições de depósito de subaquática para francamente subaérea. 


\subsubsection{Formação Botucatu}

Abrangendo área superior a $1.300 .000 \mathrm{Km} 2$, os sedimentos desta unidade desenvolveram-se na Bacia do Paraná, desde o Rio Grande do Sul penetrando em território uruguaio e no nordeste da Argentina e leste do Paraguai até os estados do Mato Grosso e Rondônia.

WHITE (op. cit.) atribui a unidade superior da "série sedimentar" do sistema de Santa Catarina, incluída na "Série São Bento", a designação "Grés de São Bento".

MAACK (1947) considerou o "Arenito São Bento inferior ou Botucatu" como caracterizado por depósitos desérticos em forma de dunas, escudos arenosos e sedimentos fluviais de depressão sem escoamento.

\subsubsection{Formação Serra Geral}

DERBY (1878) foi quem pela primeira vez descreveu estas rochas efusivas básicas, num perfil realizado ao longo da estrada que liga a localidade da Serra da Esperança e Guarapuava, no oeste do estado do Paraná. WHITE (1908), ao estudar os carvões do sudeste catarinense e a estratigrafia das rochas que os encaixam, referiu-se às rochas basálticas da região do Rio São Bento, denominando-as Eruptivas da Serra Geral e incluindo-as na "Série de São Bento", denominação por este mesmo autor cunhada.

GORDON Jr. (1947), redefiniu as "Eruptivas da Serra Geral" de WHITE (op. cit.) como Formação Serra Geral e verificou a ausência de olivina e materiais piroclásticos nos basaltos desta unidade, referindo-os a uma atividade vulcânica calma, fissural, que teria se manifestado durante o Jurássico. A Formação Serra Geral é considerada como agrupando uma espessa seqüência de vulcanitos, eminentemente basálticos, podendo conter termos ácidos intercalados, que se tornam mais abundantes no topo do pacote, a qual, tendo-se extravasado desde o triássico superior, desenvolveu-se de modo significativo durante o juro-cretáceo. 


\subsection{7 - Corpo Alcalino de Anitápolis}

O maciço Alcalino de Anitápolis é um corpo subcircular, situado em região dominada por granitóides pré-cambrianos, na borda da bacia do Paraná. Ocupa uma área de $6,0 \mathrm{~km}^{2}$ e é coberto por depósitos de talus. Dados subsuperficiais indicam uma distribuição concêntrica das várias rochas alcalinas, agrupadas em "séries", com as dos sienitos e nefelina sienitos na periferia, e a dos ijolitos e das ultramáficas ocorrendo no interior do maciço; o conjunto é cortado por veios de carbonatito sovítico, concentrados principalmente na porção central.

O manto de alteração ao redor de $30 \mathrm{~m}$ de espessura, com variações locais é subdividido em três níveis. O superior (até cerca de $20 \mathrm{~m}$ ) é o depósito de talus, constituído por matacões, em matriz siltico-argilosa; como minerais, predominam feldspatos, goethita, vermiculita e/ou esmectitas e caolinita, com algum quartzo (proveniente de rochas encaixantes), fosfatos secundários e magnetita; em um nível inferior ("horizonte $A "$ ), aparece também apatita residual, anfibolito e piroxênio. Sotoposto encontra-se o "horizonte B" de rocha decomposta (espessura média de $10 \mathrm{~m}$ ), constituído por feldspatos, vermiculita, limonita, vários argilominerais, apatita, piroxênio e anfibólio. O "horizonte C", é de rocha semidecomposta e está colocado acima da rocha fresca; é o de menor expressão, e a sua mineralogia é a da rocha subjacente (ocorrendo biotita/ flogopita parcialmente alterada e calcita remanescente).

Dados radiométricos identificam um intervalo da ordem de 10 milhões de anos para o magmatismo na Bacia do Paraná, com idades entre 138 e 128 milhões de anos, decrescentes de noroeste para sudeste. Esses estudos apontam, ainda, variações da ordem de 1 milhão de anos da base até o topo da pilha em vários perfis da bacia.

O magmatismo da Bacia do Paraná é exuberantemente exposto nos estados do sul do Brasil, principalmente no Parque Nacional dos Aparados da Serra, no litoral de Torres (RS), nas magníficas cataratas de Iguaçú (PR) e nas diversas estradas que percorrem as escarpas da serra gaúcha e catarinense. 


\section{7 - Cenozóico}

\subsubsection{Neógeno - Depósitos Recentes}

São englobados nesta unidade, os depósitos coluviais e aluviais atuais e subatuais, que ocupam as encostas dos morros e as calhas dos rios, sendo constituído por cascalhos, areias, siltes e argilas.

Os sedimentos mais grosseiros localizam-se, de modo preferencial nas cabeceiras das drenagens oriundas da escarpa basáltica, enquanto que a sedimentação síltica-argilosa desenvolveu-se acentuadamente nas extensas planícies de inundação.

Os depósitos do tipo gravitacional de encosta são, segundo VILLWOCK et alli (1984), compostos por conglomerados, diamictitos, arenitos conglomeráticos, arenitos e lamitos vermelhos, maciços ou com estruturas acanaladas, gradando para sistemas de leques aluviais e canais anastomosados e os fluviais são caracterizados por depósitos isolados, não litificados, de cascalhos e areias contendo estratificação irregular e imbricação de seixos, interpretados como depósitos de planícies e canais subatuais e indiferenciados.

\subsubsection{Depósitos Aluviais e Coluviais}

As planícies costeiras dos estados do Paraná e Santa Catarina são também caracterizadas por extensos depósitos continentais, essencialmente terrígenos de origem e idade diversas. No sopé da Serra do Mar há rampas coluviais representando episódios de fenômenos de movimentos de massa generalizados (BIGARELLA \& SALAMUNI, 1961).

\subsubsection{Sedimentos Marinhos}

São sedimentos depositado abaixo do nível do mar, ocupando as zonas nerítica, batial ou abissal. Em certas áreas litorâneas, no entanto, também podemos encontrar sedimentos de origem marinha situados a vários metros acima do nível atual dos mares, provando uma oscilação entre as terras e as águas. 


\begin{tabular}{|c|c|c|c|c|c|c|}
\hline \multicolumn{7}{|c|}{ ESBOÇO ESTRATIGRÁFICO REGIONAL } \\
\hline ERA & \multicolumn{2}{|c|}{ PERÍODO } & GRUPO & \multicolumn{2}{|c|}{ FORMAÇÃO } & LITOLOGIAS E PALEOBIOLOGIA \\
\hline \multirow{3}{*}{ CENOZÓICO } & \multirow{3}{*}{\multicolumn{2}{|c|}{ NEÓGENO }} & & & & Sedimentos Continentais aluvionares. \\
\hline & & & & & & \begin{tabular}{|l} 
Sedimentos marinhos inconsolidados. \\
\end{tabular} \\
\hline & & & & & UERIM & Dep. Rudáceos, homogêneos, alteração de rx ígneas. \\
\hline \multirow{3}{*}{$\begin{array}{l}\overline{0} \\
\text { No } 0 \\
\text { W } \\
\sum \\
\sum\end{array}$} & \multicolumn{2}{|c|}{ CRETÁCEO } & & & & $\begin{array}{l}\text { Diques basálticos e Plutões sieníticos,Fonolíticos e } \\
\text { Carbonáticos }\end{array}$ \\
\hline & \multirow{2}{*}{\multicolumn{2}{|c|}{$\begin{array}{l}\text { JURÁSSICO } \\
\text { TRIÁSSICO }\end{array}$}} & \multirow{3}{*}{ SÃO BENTO } & \multirow{2}{*}{\multicolumn{2}{|c|}{$\begin{array}{l}\text { SERRA GERAL } \\
\text { PIRAMBÓIA E } \\
\text { BOTUCATÚ }\end{array}$}} & Derrames e Sills de basalto e Andesitos \\
\hline & & & & & & $\begin{array}{l}\text { Arenitos, Siltitos e raramente Conglomerados, Colluousaria e } \\
\text { Therapsida }\end{array}$ \\
\hline \multirow{10}{*}{ 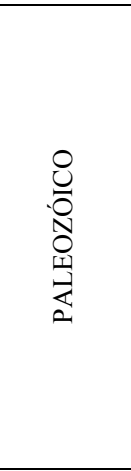 } & \multirow{10}{*}{ 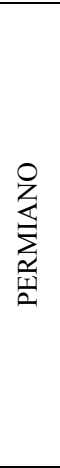 } & \multirow{5}{*}{ SUP. } & & & & Intrusões gábroicas com diferenciados Alcalinos \\
\hline & & & \multirow{4}{*}{$\begin{array}{l}\text { GRUPO PASSA } \\
\text { DOIS }\end{array}$} & \multicolumn{2}{|c|}{ RIO DO RASTO } & $\begin{array}{l}\text { Siltitos e Arenitos verdes ou vermelhos e Calcarenitos, } \\
\text { Endothiodon, Leinzia, Terraiopsis, Phyioteca e Calamites. }\end{array}$ \\
\hline & & & & \multicolumn{2}{|c|}{ TEREZINA } & Siltitos, Calcários, Pinzoneilla neotropica. \\
\hline & & & & \multicolumn{2}{|c|}{ SERRA ALTA } & Lamitos, Folhelhos, Maackia, Tholonotus, Acantholeaia. \\
\hline & & & & & & Argilitos, Folhelhos pirobetuminosos, Mesosaurus brasiliensis. \\
\hline & & \multirow[b]{2}{*}{ MED. } & \multirow[b]{2}{*}{ GRUPO GUATÁ } & \multicolumn{2}{|c|}{ PALERMO } & \begin{tabular}{|l|} 
Siltitos cinzentos, Cardiocarpus e Dadoxylon \\
\end{tabular} \\
\hline & & & & \multicolumn{2}{|c|}{ RIO BONITO } & $\begin{array}{l}\text { Arenitos, Siltitos verdes ou vermelhos e camadas de carvão, } \\
\text { Plicoplasia sp, Sarguinolites brasiliensis, Glossopter e } \\
\text { Gangamopteris. }\end{array}$ \\
\hline & & \multirow{3}{*}{ INF. } & \multirow{3}{*}{$\begin{array}{l}\text { GRUPO } \\
\text { ITARARÉ }\end{array}$} & \multicolumn{2}{|c|}{ TACIBA } & $\begin{array}{l}\text { Folhelhos e Siltitos cinzentos, Arenitos, Diamectitos, Chonetes } \\
\text { sp, Langella imbituvensis, Warthia sp, Heteropectem catharina }\end{array}$ \\
\hline & & & & \multirow{2}{*}{\multicolumn{2}{|c|}{$\begin{array}{c}\text { CAMPO MOURÃO } \\
\text { LAGOA AZUL }\end{array}$}} & Arenitos, Siltitos, Ritimitos, Elonicthys gonwanus \\
\hline & & & & & & Arenitos Grosso, Siltitos e Diamectitos \\
\hline \multirow{10}{*}{ 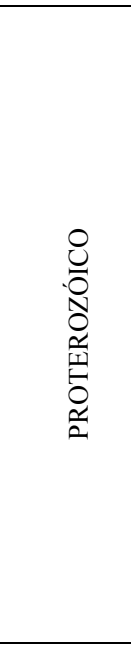 } & \multirow{6}{*}{\multicolumn{2}{|c|}{ SUP. }} & \multirow{4}{*}{ GRANITÓIDES } & \multicolumn{2}{|c|}{ SUÍTE INTR. SUBIDA } & $\begin{array}{l}\text { Corpo circunscrito, intrusivo, alcalino a perialcalino, } \\
\text { leucocrático, sieno-granítico avermelhado grosseiro }\end{array}$ \\
\hline & & & & $\begin{array}{ll}\text { SUI } \\
\text { GU }\end{array}$ & $\begin{array}{l}\text { TE INTR. } \\
\text { ABIRUBA }\end{array}$ & $\begin{array}{l}\text { Ortoclásio-Granitos finos, biotíticos, dissiminações de } \\
\text { wolframita, cassiterita, muscovita, foliação milonítica. }\end{array}$ \\
\hline & & & & $\begin{array}{l}\text { SUÍTE } \\
\text { PEDRA }\end{array}$ & $\begin{array}{l}\text { INTRUSIVA } \\
\text { S GRANDES }\end{array}$ & $\begin{array}{l}\text { Granitóides não deformados, granodioríticos, domínios } \\
\text { alcalinos, subalcaninos, biotíticos }\end{array}$ \\
\hline & & & & $\begin{array}{l}\text { SUÍTE } \\
\text { VAL }\end{array}$ & $\begin{array}{l}\text { INTRUSIVA } \\
\text { SUNGANA }\end{array}$ & $\begin{array}{l}\text { Batólitos graníticos c/ rochas, cores creme e avermelhdas c/ } \\
\text { macrocristais de feldspato potássico }\end{array}$ \\
\hline & & & & FORM. & $\begin{array}{l}\text { SEQ. VULC. } \\
\text { SUP. }\end{array}$ & $\begin{array}{l}\text { Riolitos e traquitos c/ estruturas fluidais, raras intercalações } \\
\text { sedimentares epiclásticas finas. }\end{array}$ \\
\hline & & & GRUPO ITAJAÍ & $\begin{array}{l}\text { CAMPO } \\
\text { ALEGRE }\end{array}$ & $\begin{array}{l}\text { SEQ. SEDIM. } \\
\text { INT. }\end{array}$ & $\begin{array}{l}\text { Siltitos verdes, rítmicos, arenitos, tufos, brechas, vulcanitos } \\
\text { ácidos, estruturados localmente, "pillow" }\end{array}$ \\
\hline & & & & FORMA & ÇÃO GASPAR & Arenitos litofeldpáticos, grosseiros, bordô, maciços \\
\hline & & ÉD. & & CONGLO & MERADO BAÚ & Conglomerados polimíticos grosseiros transicionais \\
\hline & & & COMPLEXO & SEQUÊNC & IA TERRÍGENA & $\begin{array}{l}\text { Micaxistos, granada micaxistos; mármores, metarenitos, } \\
\text { metavulcânicas ácidas, filonitos. }\end{array}$ \\
\hline & & NF. & $\begin{array}{l}\text { METAMORFICO } \\
\text { BRUSQUE }\end{array}$ & $\begin{array}{r}\text { SEC } \\
\text { VULC }\end{array}$ & $\begin{array}{l}\text { QUENCIA } \\
\text { ANO-SEDIM. }\end{array}$ & $\begin{array}{l}\text { Micaxistos, metarenitos, quartzitos, metagrauvacas, } \\
\text { metacalcáreos, dolomíticos, metacherts, BIFs }\end{array}$ \\
\hline & & & & $\begin{array}{r}\mathrm{N} \\
\mathrm{MIGN}\end{array}$ & $\begin{array}{l}\text { ÚCLEO } \\
\text { I.ITAPEMA }\end{array}$ & Granitóides neossômicos bandados, foliados, tonalíticos. \\
\hline そ & & O & COMPLEXO & $\begin{array}{r}\text { FAIX } \\
\text { STA. RC }\end{array}$ & $\begin{array}{l}\text { I GRA/GNA } \\
\text { OSA DE LIMA }\end{array}$ & $\begin{array}{l}\text { Rochas com estrutura planar orientada, foliação milonítica, alto } \\
\text { o, estiramento mineral c/ sombra de pressão }\end{array}$ \\
\hline 近 & & $\sum_{2}^{2}$ & TABULEIRO & $\begin{array}{r}\text { FAIX } \\
\text { GA }\end{array}$ & $\begin{array}{l}\text { A GRA/GNA } \\
\text { ROPABA }\end{array}$ & Fácies porfiróides, grosseiro, faciodal, estrutura planal de alto ${ }^{\circ}$ \\
\hline$\approx$ & & & & $\begin{array}{r}\text { FAIXA GR } \\
\text { F } 1 \\
\end{array}$ & $\begin{array}{l}\text { A/GNA ITAJAÍ- } \\
\text { AXINAL }\end{array}$ & $\begin{array}{l}\text { Fácies granitóides miloníticas interdigitados p/ transposição c/ } \\
\text { xistos supracrustais, baixo }^{\circ}\end{array}$ \\
\hline & & & $\begin{array}{l}\text { COMPLEXO } \\
\text { GRANUL. SC }\end{array}$ & & & $\begin{array}{l}\text { Gnaisses hipertênicos, qtzo-feldpatíticos, calcossilicatados, } \\
\text { kinzigitos, anortositos, BIFs, metaultramáficas. }\end{array}$ \\
\hline
\end{tabular}

Tab. 5.1 - Coluna litoestratigráfica Regional modificada, em destaque (cor azul) as Formações encontradas regionalmente associadas às águas termais e termo-minerais. Referência Projeto Cadastro de Recursos Minerais de Santa Catarina, 1989. 


\section{8 - GEOLOGIA DE DETALHE DA ÁREA DE PESQUISA}

Neste item será descrita a geologia dos locais de ocorrência de águas termais e termo-minerais na região centro-sul da Borda Oriental do Estado de Santa Catarina. Para um melhor entendimento convencionou-se distribuir as ocorrências em duas grandes áreas, caracterizadas pelos seguintes municípios:

\subsection{1 - Área 01 - Santo Amaro da Imperatriz, Águas Mornas, São José e Palhoça}

As rochas mais antigas da área fazem parte do Complexo Metamórfico-Migmatítico, de possível idade Arqueana, segundo SILVA (1982). As rochas deste complexo são individualizadas em migmatitos polifásicos, com paleossoma de natureza básica a ácida e neossoma granito-quartzo-monzonítico; e migmatitos com hábito plutônico, homofânicos, com estruturas schlieren, nebulíticas e composição granítica a tonalítica.

A área do Complexo Águas Mornas foi incluída por SILVA (1987) na Faixa Granito-Gnáissica Santa Rosa de Lima/Tijucas, integrante do denominado Cráton de Itapema, para o qual o autor sugeriu uma consolidação no Arqueano/Proterozóico Inferior, com retrabalhamentos nos ciclos Tranzamazônico e Brasiliano.

Pelas considerações de ZANINI (1997), ele abandona o termo Grupo Taboleiro para a região e reúne as rochas granito-gnáissicas sob a denominação informal de Complexo Águas Mornas, o qual forma uma faixa de direção grosseiramente leste-oeste desde as localidades de Rio do Miguel e Rio do Cedro até o litoral de Palhoça.

O Complexo Águas Mornas compreende uma associação de ortognaisses polifásicos, de composição diversificada, aparentemente derivada de uma Seqüência pretérita gnássica-migmatítica, constituída dominantemente por paleossomas de natureza básica a intermediária (ortoanfibolitos, metagabros, metabasitos, metadioritos) e por gnaisses quartzo-dioríticos e granodioríticos. 
O contato ao sul, com o Complexo Águas Mornas, fora dos limites da área estudada, são na maioria tectônicos, com as rochas do Granito Serra do Tabuleiro, denominação esta feita por ZANINI (op. cit.). Esta designação abrange as rochas que TRAININI et alli (1978) chamaram de Granito Tabuleiro. A substituição foi julgada conveniente para evitar confusões com o Complexo Tabuleiro de SILVA (1987), denominação utilizada por ZANINI (op. cit.) para agrupar associações granito-gnáissicas de natureza diversificada e migmatitos.

O Granito Serra do Tabuleiro constitui um batólito de forma aproximadamente circular, com cerca de $25 \mathrm{Km}$ de diâmetro, que ocupa a metade sul da Folha de Florianópolis. Seus contatos com as unidades mais antigas tais como o Complexo Águas Mornas, são tectônicos em toda sua extensão.

Compreende rochas mesoscopicamente homogêneas, com cor usualmente rósea, eqüigranulares médias a grossas e isótropas. São classificadas como sienogranitos predominantemente, acompanhadas por monzogranitos, quartzo sienitos e quartzo monzonitos.

Os depósitos paleógenos/ neógenos estão representados nas encostas sob a forma de tálus, nos vales apertados em forma de "V" e vales côncavos, por depósitos pequenos do tipo colúvio ou pouco transportado (no caso do depósito de tálus) e do tipo aluvionar formado principalmente por atividades fluviais ao longo dos vales.

Nos aluviões encontram-se todas as frações representadas desde argilas, areias, seixos e blocos. Constituem-se estes depósitos, de minerais como quartzo leitoso, quartzo hialino, feldspatos potássicos, micas (principalmente), seixos e blocos rochosos de migmatitos e rochas granitóides.

Os solos possuem comportamento menos variável. No horizonte "A" predominam cores de marrom a marrom escuro, com húmus, areia por vezes predominando sobre argila e tendo, em média $15 \mathrm{~cm}$, chegando excepcionalmente a $50 \mathrm{~cm}$.

As cores mais presentes no horizonte "B" são laranja claro a escuro, vermelho escuro a vermelho bordô, distribuídas às vezes em faixas bem como cinza amarelado. A fração predominante na parte de topo do horizonte "B" é areia fina, secundariamente silte e argila. Descendo no horizonte, passa a dominar argila e silte (menos areia), sendo que a espessura média deste horizonte "B" vai de 1,0 m a 
5,0 m. Outra presença marcante são os seixos, preservados, geralmente matérias de composição granitóide (veios de quartzo) e migmatítica. Quase sempre presente onde a rocha aparece totalmente alterada e friável, aparece o horizonte $\mathrm{C}$, mostrando cores geralmente em torno do laranja esbranquiçado a vermelho fraco, sendo que esta alteração é facilitada pelo fraturamento cataclástico. Os solos, na sua maioria, são autóctones ou gerados "in situ", ocorrendo por vezes, uma pequena cobertura alóctone.

\subsection{2 - Área 02 - Tubarão, Pedras Grandes, Gravatal e região}

O mapeamento geológico efetuado na região sul da área pesquisada, na região dos municípios de Tubarão, Pedras Grandes, Gravatal, Santa Rosa de Lima, São Bonifácio, Armazém, Braço do Norte e Imaruí, possibilitou definir que o trato rochoso é constituído principalmente por rocha granítica, definida por SILVA (1987), como pertencente a Suíte Intrusiva Pedras Grandes.

Os principais afloramentos ocorrem ao longo dos rios e riachos que cortam a região. Nas encostas dos morros se verifica a ocorrência de matacões de dimensões variadas.

Estas rochas apresentam variação irregular e por vezes gradual desde um granito acinzentado até avermelhado. Ambas as fácies variam texturalmente de aspecto tipicamente equigranular, homogêneo, à feições mais grosseiras e porfiróides. Tal variação faciológica apresenta contatos difusos, sendo resultante provavelmente das condições de temperatura e pressão e conseqüentemente, mobilidade em meio fluído em ambiente de catazona.

Petrograficamente, de modo generalizado, o plagioclásio é o oligoclásio e o máfico dominante a biotita marrom e subordinadamente a hornblenda. A textura granítica (granular hipidiomórfica) raramente exibe efeitos limitados de microgranulação mecânica ou de crescimento tardio de cristais feldspatos de dimensões entre $1 \mathrm{~cm}$ e $3 \mathrm{~cm}$, imersos em matriz, média a grosseira, a microclínio, oligoclásio, biotita e hornblenda. Em alguns afloramentos foi observada a presença de pintas de pirita. 
Nas zonas de fraturas pode-se observar que nas encaixantes ocorrem uma fraca alteração hidrotermal, caracterizada por descoloração, argilização, epidotização, cloritização e silicificação.

Os granitóides da Suíte Intrusiva Pedras Grandes sofreram intensos esforços compressivos, que geraram estruturas cataclásticas, produzindo litologias do tipo brechas de falha, as quais, por vezes, podem ser acompanhadas em campo através de extensos lineamentos, ultrapassando inclusive, os limites da área de estudo.

Ao longo da falha regional $\mathrm{N} 20^{\circ} \mathrm{W}$ foi identificada uma zona de catáclase mais intensa, podendo-se encontrar ao longo da mesma, litologias relacionadas a rochas cataclásticas.

Rochas semelhantes a milonitos, de granulação fina, com orientação planar dos cristais e estiramento acentuado, são encontrados em alguns locais da área mapeada, principalmente ao longo das falhas principais; a despeito de normalmente serem rochas pulverizadas por efeitos tectônicos.

O quartzo e feldspato é a associação mais comum destas rochas, pois estes minerais são estáveis quimicamente, em amplas faixas de temperatura e pressão.

As rochas cataclásticas que aparecem na região não alcançaram o extremo da granulação típica dos milonitos, podendo-se reconhecer a natureza da rocha matriz, pelo exame da mineralogia e textura dos fragmentos ainda não destruídos, a qual, provavelmente, tem uma composição de quartzo, feldspato alcalino, plagioclásio, biotita, epidoto e sericita.

A Formação Serra Geral foi encontrada na forma de diques de diabásio, controlados por falhamentos NNE. Em alguns locais esta rocha foi identificada pela alteração do solo, ou através da diferenciação de cores entre a rocha encaixante e a intrusiva.

Os sedimentos quaternários Igualmente foram delimitados superficialmente três domínios de depósitos recentes, denominados de acordo com seu modo de ocorrência em depósitos coluviais, flúvio-coluviais e fluviais.

Os depósitos coluviais são formados por conglomerados imaturos e inconsolidados, com dominância de seixos, blocos e matacões de granitos, localizados ao longo das encostas, estando condicionados à energia do relevo, que 
por ser bastante elevada, propiciou o deslocamento de materiais. Associado aos matacões ocorrem argilas e areias de cores variadas desde amarela a amarronzadas, mostrando por vezes, gradação lateral, em direção ao talvegue para depósitos aluviais típicos.

Em relação aos demais horizontes deste domínio, nota-se ao longo dos trabalhos de pesquisa executados que ocorre uma gradação vertical nas camadas do solo, das frações areno-síltico argilosa para grânulos, seixos até matacões, onde normalmente dominam a fração média a grosseira das areias com granulometria de $0,25 \mathrm{~mm}$ a $2,00 \mathrm{~mm}$, sendo que os matacões são no geral uma constante e podem variar de $0,3 \mathrm{~m}$ a $0,9 \mathrm{~m}$ de diâmetro.

Ao longo do vale onde se encaixa a falha regional, são encontradas litologias de difícil definição, estando situadas mais ao sopé das vertentes, caracterizadas como sedimentos flúvio-coluviais. Neste material detrítico, pouco grosseiro, de encosta, nem sempre é fácil separarmos a interferência do material de colúvio, do residual ou ainda do aluvial (fluvial). Às vezes, há maior predominância de um deles, que mascara completamente os outros.

Na tentativa de caracterizar os depósitos flúvio-coluviais tal qual foi feito para os colúvios, denotou-se que ocorre uma similaridade muito grande no horizonte "A", onde praticamente não há diferença litológica; segue-se os demais horizontes onde há o domínio da fração síltico-argilosa, explicável de certa forma no presente caso, por ter havido uma migração lateral da sedimentação mais fina (colúvios) por lixiviação, bem como na vertical, onde se observam maiores espessuras com ocorrência de seixos e matacões imersos nesta matriz. Quanto a granulometria da fração arenosa bem como dos seixos e matacões, é semelhante ao domínio dos colúvios.

Nos barrancos ou mesmo em terraços das margens das drenagens, pode-se às vezes notar que há uma interdigitação de horizontes da sedimentação coluvial que sofreu solapamento para as vertentes e a sedimentação tipicamente fluvial gerada a partir do transbordamento dos córregos, ou seja, pode-se encontrar horizontes coluviais sobre fluviais ou vice-versa, num mesmo perfil de solo.

Sedimentos arenosos constituem também barras de meandros, que podem ser observados principalmente próximos a surgência de água, associados a blocos de quartzo angulosos, grânulos e alguns matacões graníticos. 


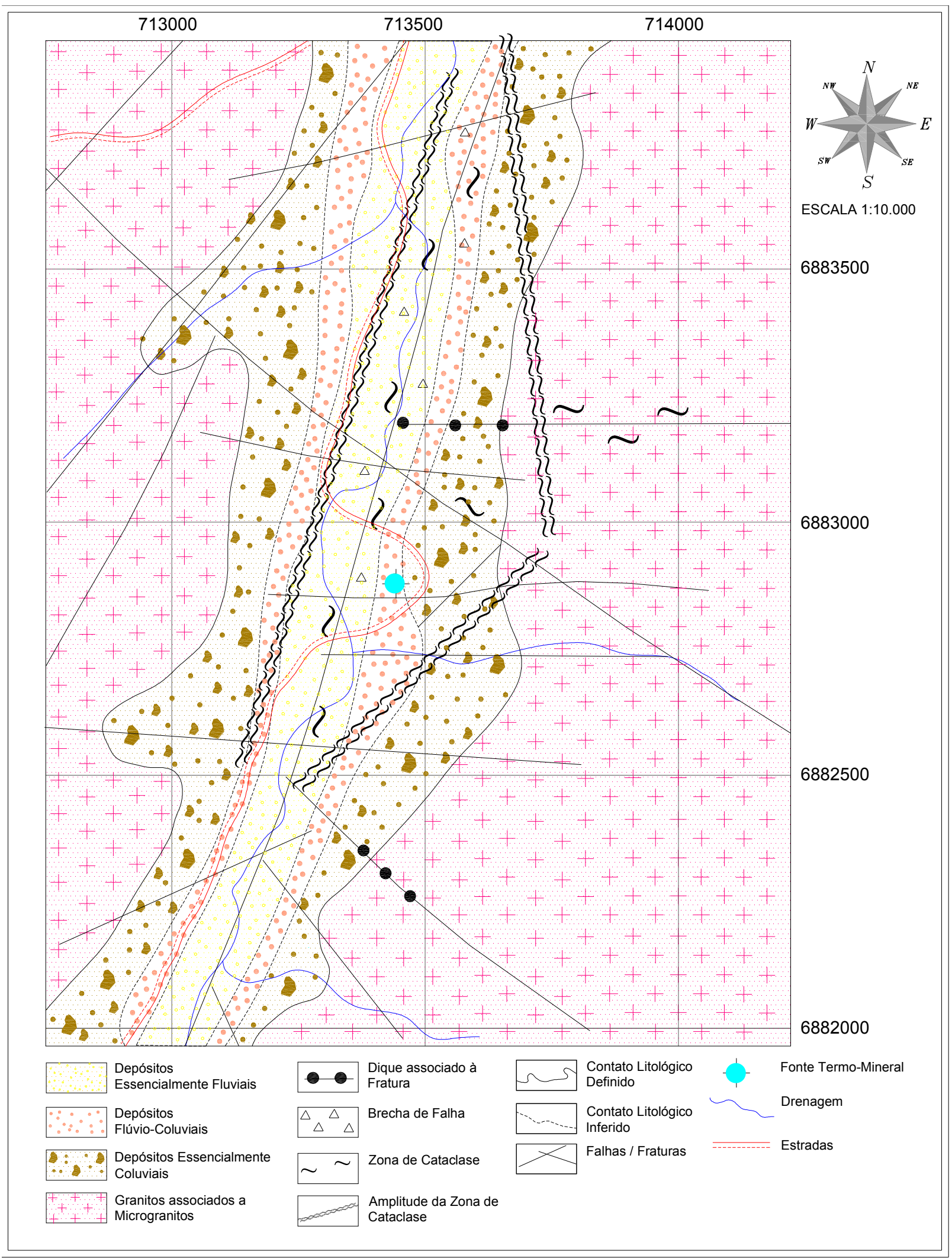

Fig. 5.1 - Mapa Geológico detalhado da região chamada Águas Mornas, Município de Imaruí. 


\section{9 - CARACTERIZAÇÃO DO ARCABOUÇO TECTÔNICO REGIONAL E DA ÁREA DE PESQUISA}

\subsection{1 - Tectônica Regional}

O arcabouço tectônico obedece ao padrão regional de tectônica rígida estudada por vários pesquisadores, destacando-se os trabalhos de Leinz, Putzer, Schulz, Albuquerque, Teixeira e Trainini.

Segundo LEINZ (1949), "os esforços tectônicos de tensão manifestaram-se com grande intensidade em certas zonas, formando um geoclasamento pronunciado e fornecendo assim adutores primários do magma. Lembramos como protótipo dessas faixas, a zona tectônica Torres-Posadas".

PUTZER (1953) associa, temporal e geneticamente, o tectonismo que afetou as rochas gonduânicas da Bacia do Paraná com o vulcanismo basáltico. Para esse autor, um levantamento epirogênico do Escudo Sul Brasileiro, começou pela mobilização do magma, proveniente da ação dos gases. Os estratos basais respondendo aos esforços verticais arquearam-se, provocando fraturamentos tensionais nos estratos superiores, que foram utilizados pelo magma como canais de ascensão.

Segundo PUTZER (1955), ocorre a predominância de dois sistemas de fraturamento com direções ao redor de $\mathrm{N} 30^{\circ} \mathrm{E}$ e $\mathrm{N} 60^{\circ} \mathrm{E}$ e direções conjugadas, respectivamente, ao redor de $\mathrm{N} 60^{\circ} \mathrm{W}$ e N30 $\mathrm{W}$. Tais sistemas correspondem ao "Sistema Catarinense" ( $\left.\mathrm{N} 60^{\circ} \mathrm{E}\right)$, correspondendo a zona de fraturamento reativada e recortam os estratos sedimentares da Bacia do Paraná. O Sistema Riograndense $\left(\mathrm{N} 30^{\circ} \mathrm{E}\right)$, corresponde às falhas normais.

Segundo SCHULZ Jr. et alli (1970), a densidade de fraturamento aumenta gradativamente em direção ao litoral; as direções $\mathrm{N}-\mathrm{S}$ e $\mathrm{N} 50^{\circ}-60^{\circ} \mathrm{E}$, dominantes no sul, perdem sua expressão, para um denso sistema $\mathrm{N} 40^{\circ}-50^{\circ} \mathrm{E}$. A zona de transição entre os dois sistemas estaria no núcleo da Serra do Tabuleiro, explicando em parte o intenso fraturamento das litologias que a compõem.

ALBUQUERQUE et alli (1971), evidenciaram diversas fases tectônicas: a primeira fraturou de maneira notável rochas do Grupo Taboleiro, com 
direção predominante nordeste, de grande extensão, sendo algumas destas posteriormente cortadas por falhas E-W menores. A intrusão de diversos corpos graníticos alcalinos e calco-alcalinos, deu-se por influência desses falhamentos. A grande maioria das falhas normais de direção nordeste são, portanto, resultado de esforços predominantemente de distensão, o que caracteriza essa tectônica, como do tipo germanótipo.

De acordo com TRAININI et alli (1978), as falhas regmáticas primitivas, no sentido de Boutakoff e outros, sofreram durante o ciclo Brasiliano, reativações através da atuação de esforços compressionais no intervalo direcional $\mathrm{N} 75^{\circ} \mathrm{E}$ e $\mathrm{S} 75^{\circ} \mathrm{W}$.

Ainda segundo os autores acima, pela continuidade dos esforços compressivos, os mosaicos crustais sofreram rotação horária acompanhada de desenvolvimento de "drag folds" e fraturas de cisalhamento de $2^{\mathrm{a}}$ ordem, correspondentes às seguintes direções:

N-S - fraturas de tensão $2^{a}$ ordem;

$\mathrm{N} 15^{\circ}-25^{\circ} \mathrm{E}$ - fraturas de cisalhamento de $2^{\mathrm{a}}$ ordem, levógiras;

* E-W - "drag folds" de $2^{\mathrm{a}}$ ordem e "up thrusts".

MORGENTAL \& KIRCHNER (1983), baseado em estudos de fotografias aéreas, imagem de radar e mapas aeromagnetométricos interpretaram que na região as falhas enquadram-se nos sistemas $\mathrm{N} 60^{\circ} \mathrm{E}, \mathrm{N} 30^{\circ} \mathrm{E}, \mathrm{N} 30^{\circ} \mathrm{W}, \mathrm{NW}$ e $\mathrm{N} 60^{\circ} \mathrm{W}$.

Segundo ZANINI (1997), o domínio estrutural do Complexo Águas Mornas está possivelmente condicionado por reativações de falhas do Granito Serra do Tabuleiro; suas atitudes médias são segundo ENE, com mergulhos muito variáveis influenciados pelos falhamentos; estão representados pela zona de cizalhamento de Santo Amaro da Imperatriz que separa estas rochas com aquelas do Granito Serra do Tabuleiro, com características de estruturação N60-65ㅌ. 


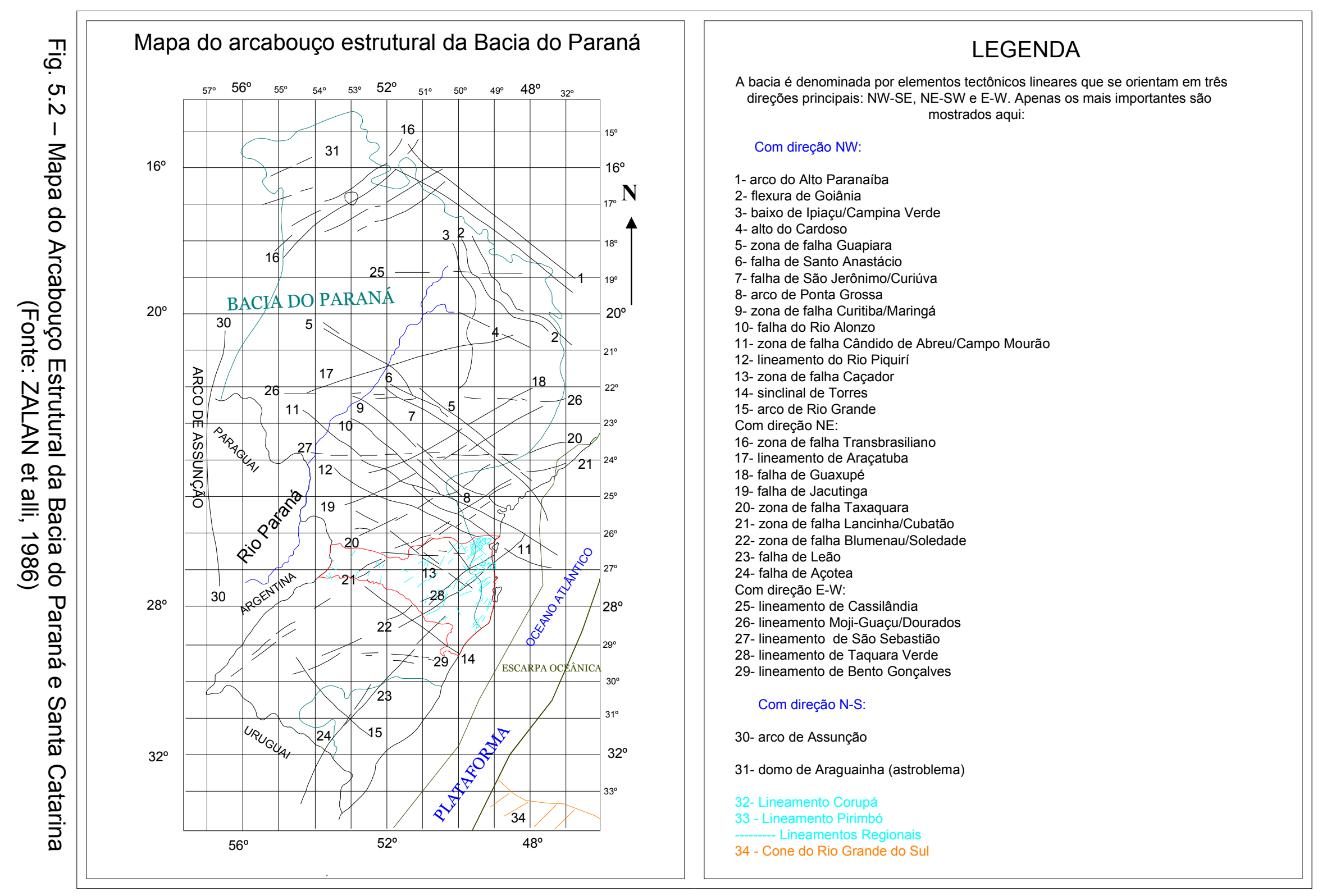




\subsection{2 - Tectônica da Área de Pesquisa}

\subsubsection{1 - ÁREA 01 - Santo Amaro da Imperatriz, Águas Mornas, Palhoça e São José}

$\mathrm{Na}$ região norte da área da pesquisa, ocorrem duas estruturas principais de orientação $\mathrm{N} 10^{\circ} \mathrm{E}$ e $\mathrm{N} 48^{\circ} \mathrm{E}$, que correspondem as falhas do "Sistema Riograndense" e do "Sistema Catarinense". De acordo com PUTZER (op. cit), a falha de orientação $\mathrm{N} 10^{\circ} \mathrm{E}$ corresponde a uma falha normal, enquanto que a falha $\mathrm{N} 48^{\circ} \mathrm{E}$ é reativada.

O rio Cubatão, em alguns trechos se encaixa na falha de maior ângulo e esta é recortada pela falha $\mathrm{N} 10^{\circ} \mathrm{E}$, no limite sul da área estudada.

É importante ressaltar, com base nos levantamentos efetuados na região, as ocorrências das fontes de águas termo-minerais estão sob o controle estrutural da falha $\mathrm{N} 52^{\circ} \mathrm{E}$.

Um estudo das fotografias aéreas na escala de 1:45.000 ( $n^{\circ} \mathrm{s} 26.204$ a 26.206) e escala 1:25.000 ( $n^{\circ}$ s 20.592, 20.593 e 20.594 ) as quais permitiram uma visualização do conjunto dos principais elementos tectônicos, revelou predominância para a área, de orientação aproximada de $\mathrm{N} 50^{\circ}-55^{\circ} \mathrm{E}$, além de fraturamentos $\mathrm{N} 10^{\circ}-20^{\circ} \mathrm{E}$ e N $20^{\circ}-30^{\circ} \mathrm{W}$.

Orientações aproximadas E-W, detectadas na porção mais a sul, na Serra do Tabuleiro, também puderam ser observadas. A direção $\mathrm{N} 50^{\circ} \mathrm{E}$ corresponde, aproximadamente, ao alinhamento das fontes existentes na região de Águas Mornas.

Tendo em vista que a tectônica de quebramento foi muito intensa, seria de se esperar que fosse possível detectar um sem número de lineamentos, porém, em função da espessa cobertura de solo corroborada pela ausência de afloramentos, somente foi possível definir orientações de fraturas ao longo da BR282, graças ao corte dos taludes da mesma. 


\subsubsection{2 - ÁREA 02 - Tubarão, Pedras Grandes, Gravatal e Região}

Compreende as exposições de rochas granito-gnáissicas, com migmatitos associados, que ocorrem ao sul do Lineamento Major Gercino, nas quais estão inseridas as Suítes Graníticas Intrusivas São Pedro de Alcântara e Pedras Grandes, as rochas vulcânicas ácidas da Formação Cambirela e os metamorfitos de baixo grau da Formação Queçaba.

Neste domínio estão localizadas diversas fontes naturais e poços tubulares de águas minerais, que apresentam um forte controle estrutural (controladas por direções preferenciais de falhamentos) e apresentam características físico-químicas muito semelhantes, tais como temperatura elevada (fontes isotermais a mesotermais e algumas ocorrências de águas hipertermais), com poucas exceções; presença de radioatividade em nível médio a alto; $\mathrm{pH}$ ácido a neutro; fracamente mineralizadas; baixa condutividade elétrica (entre $8,5 \times 10^{-5} \mathrm{e}$ $1,0 \times 10^{-4} \mathrm{mhos} / \mathrm{cm}$ ); baixo resíduo de evaporação a $180^{\circ} \mathrm{C}$ (entre 40,16 e 130,3 mg/l); dureza (águas moles ou brandas) e presença de flúor, etc.

O arcabouço estrutural desta área é marcado pela dominância de quatro sistemas principais de falhamentos:

- $\mathrm{N} 0^{\circ}-20^{\circ} \mathrm{E}$;

- $\mathrm{N} 40^{\circ}-60^{\circ} \mathrm{E}$;

- $\quad \mathrm{N} 10^{\circ}-15^{\circ} \mathrm{W}$;

- $\mathrm{N} 40^{\circ}-50^{\circ} \mathrm{W}$.

Segundo FERREIRA e ALMEIDA (1989), os depósitos de fluorita e barita do Estado de Santa Catarina estão inseridos em zonas de cisalhamentos de direção preferencial $\mathrm{N} 10^{\circ} \mathrm{E}$, subordinadamente, $\mathrm{N} 60^{\circ} \mathrm{E}$.

As ocorrências de águas minerais deste domínio apresentam um forte controle estrutural, freqüentemente, com uma clara associação com mineralizações de fluorita-quartzo-barita, principalmente associadas a lineamentos de direção geral $\mathrm{N} 0^{\circ}-20^{\circ} \mathrm{E}$, com variações para $\mathrm{N} 10^{\circ}-15^{\circ} \mathrm{W}$, além de direções $\mathrm{N} 40^{\circ}$ $60^{\circ} \mathrm{E}$. 


\section{6 - CARACTERÍSTICAS FISIOGRÁFICAS}

\section{1 - Características Climáticas}

A movimentação superficial e subterrânea da água depende de vários fatores: da morfologia do terreno, do tipo e da intensidade da cobertura vegetal, da litologia, do clima e das estruturas geológicas presentes nas rochas e no solo.

Os aspectos determinam a abundância e a variabilidade da alimentação da água subterrânea no tempo e no espaço, enquanto que as litologias, na maioria dos casos, definem a importância e distribuição dos espaços armazenadores da água subterrânea.

A importância do estudo das características climáticas reside no chamado "Ciclo Hidrológico", que caracteriza a mudança constante dos estados físico-químicos da água na natureza e sua interação na formação do relevo, formação de aqüíferos e nos demais processos naturais ligados a água.

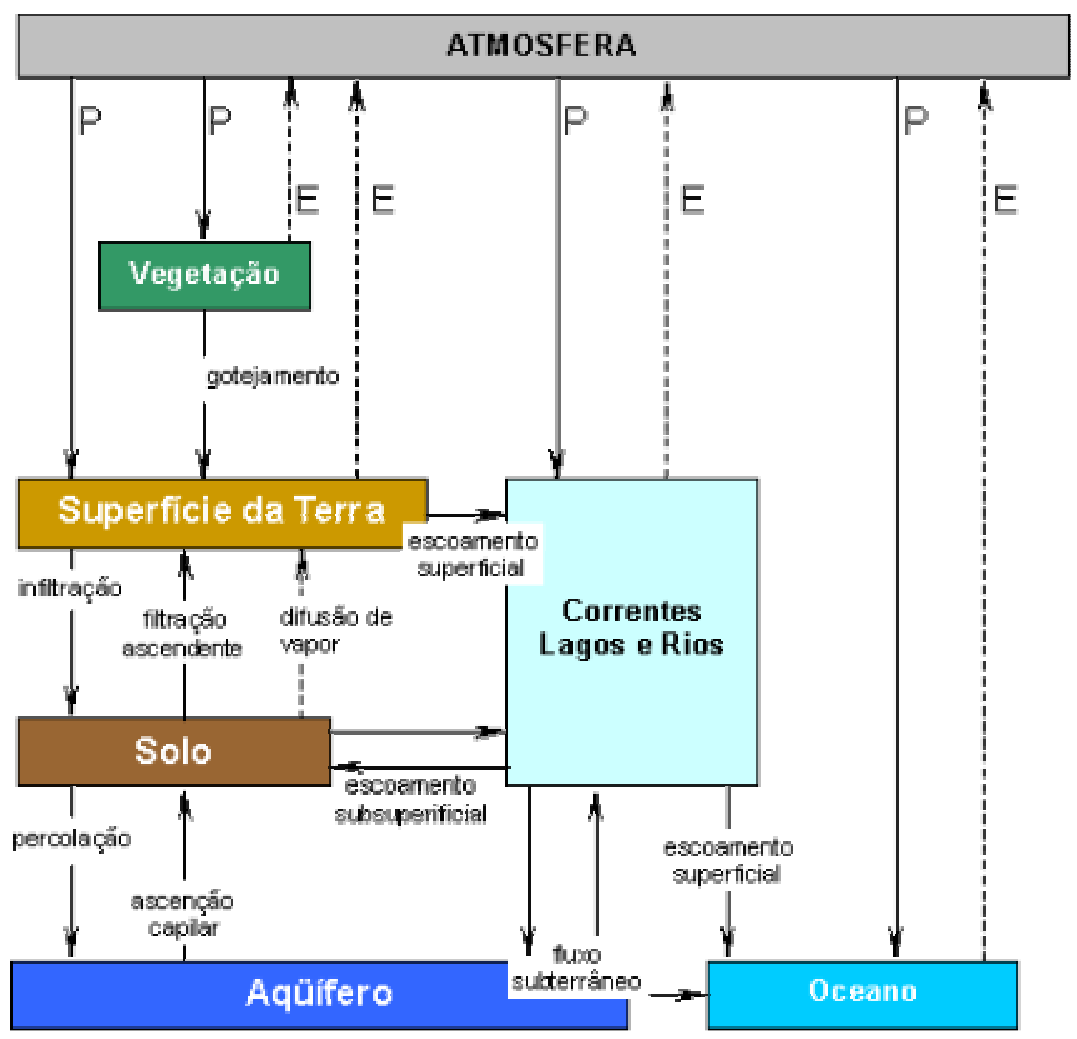

Fig.6.1 - O ciclo Hidrológico (Fonte: PORTO, 1973) 
Dentro do ciclo hidrológico, os processos de interesse para a hidrogeologia são aqueles referentes aos componentes subterrâneos, como escoamento básico e a infiltração no solo. O escoamento básico representa a descarga de água proveniente do aqüifero para os corpos de água superficial, e a infiltração constitui a contribuição da precipitação ao reservatório subterrâneo, que em sua dinâmica, retornará na forma de escoamento básico, considerando um ambiente sem interferência.

A área estudada, situada na porção transicional entre a Planície Costeira e a Serra do Leste Catarinense está localizada entre os paralelos:

\section{- $27^{0} 30^{\prime} 00^{\prime \prime}$ de latitude Sul}

- 49³0’00" de Longitude Oeste

\section{e}

- $28^{0} 30^{\prime} 00^{\prime \prime}$ de latitude Sul

\section{- 48³0'00" de Longitude Oeste}

Possui um clima de influência oceânica, com estações climáticas bem definidas e precipitação pluviométrica anual abundante, decorrente da influência da circulação atmosférica do Atlântico Sul (TUBÉLIS \& NASCIMENTO, 1980).

Sob o aspecto climatológico o sul do Brasil é atingido por grandes massas de ar formadas pelos anticiclones tropicais, além dos anticiclones polares migratórios. O movimento anticiclônico ocorre quando numa região de alta pressão o ar se move para fora do núcleo espiral da célula de pressão, no sentido antihorário (TUBÉLIS \& NASCIMENTO, op. cit.).

O Anticiclone Tropical Atlântico Sul (ATA) influencia o clima da Região Sul do Brasil. Este anticiclone é estacionário e está localizado no meio do Oceano Atlântico, na altura do trópico de Capricórnio. A pressão máxima em seu núcleo varia entre 1020 e $1023 \mathrm{hPa}$ (hectopascal). Deste centro de alta pressão, originam-se os ventos alísios que vindos de direção nordeste atingem a costa da Região Sul do Brasil. 
O mesmo autor escreve que no verão, o Anticiclone Tropical Atlântico associado aos anticiclones Atlântico e Pacífico, movimenta-se descendentemente na atmosfera, sofrendo aquecimento adiabático (sem trocar energia com o meio externo), tornando-se então uma massa quente e seca, desprovida de nebulosidade e de precipitações.

A massa de ar quente (ATA) encontra próximo à superfície da terra uma camada com temperatura relativamente menor. Isto gera uma inversão térmica, provocando grande evaporação e evapotranspiração nesta camada inferior alterando assim suas propriedades térmicas e higrométricas, onde o vapor de água se acumula, dando origem a precipitações violentas, principalmente de origem orográfica.

No inverno, na Região Sul do Brasil, o clima é influenciado pelos anticiclones polares móveis, caracterizados pela presença do ar frio na troposfera inferior. Estes se movem rapidamente e possuem pouca duração. São formados em altas latitudes, nas regiões subpolares da América do Sul (TUBÉLIS \& NASCIMENTO, op.cit.).

A célula anticiclônica forma-se, geralmente, na região depressionária subantártica, na Patagônia. Estas massas de ar são muito secas e frias e de alta estabilidade. A medida que estas massas se deslocam sobre o continente, a Região Sul é inteiramente varrida pelas frentes polares que causam precipitações pré-frontais e pós-frontais, chegando a ocorrer no sul até uma invasão por semana (TUBÉLIS \& NASCIMENTO, op.cit.).

Quando estas massas se deslocam sobre o Oceano Atlântico, ganham calor e umidade. Ao atingirem latitudes médias tornam-se instáveis. Estes anticiclones polares ocorrem durante todo o ano; durante o verão provocam intensa pluviosidade, caracterizando a época como estação chuvosa, enquanto que no inverno, com a diminuição de precipitações, caracteriza uma estação menos chuvosa.

"Massas polares envelhecidas", (massas tropicalizadas devido ao aquecimento basal durante o trajeto para o Norte), perdem suas propriedades fundamentais e são desviadas pela linha de instabilidade tropical predominante durante o verão, ocasionando então os ventos de oeste e noroeste, 
caracteristicamente fortes, com intensos aguaceiros rápidos (TUBÉLIS \& NASCIMENTO, op.cit.).

Para determinar as médias das variáveis climáticas utilizaram-se as informações contidas no ATLAS DE SANTA CATARINA (1986) e as Séries Históricas da EPAGRI e CLIMERH dos anos de 1924 a 2004, sendo a estação meteorológicas mais próximas as de Florianópolis, Urrusanga, Laguna e Orleães (vide em anexo as séries históricas utilizadas).

\subsection{1 - Pluviosidade}

Analisando-se os índices pluviométricos medidos, notou-se que não ocorre uma estação seca na região. A Tabela 6.1 mostra o índice pluviométrico durante todos os meses do ano para a região da área pesquisada. O verão é a estação mais chuvosa, sendo o mês de fevereiro o representante com maior índice médio de precipitação mensal, em torno de $172,25 \mathrm{~mm}$. O período menos chuvoso é no inverno, cujo mês representativo é junho, com média em tono de 73,45 mm. $O$ índice pluviométrico anual é geralmente mais alto que a média, o que caracteriza a região como uma das maiores áreas de incidência pluviométrica do Estado de Santa Catarina

\begin{tabular}{|c||c|c|c||c||c|c|c||c||c||c||c||c||}
\hline \hline Mês / Estação & jan & fev & mar & abr & mai & jun & jul & ago & set & out & nov & dez \\
\hline \hline Florianópolis & 192.6 & 189.7 & 169.3 & 128.2 & 106.3 & 85.1 & 81.6 & 93.1 & 116.1 & 132.4 & 132.3 & 138.7 \\
\hline \hline Urussanga & 202.8 & $\mathbf{2 0 3 . 9}$ & 160.3 & 103.4 & 93.0 & 84.7 & 92.1 & 109.6 & 126.2 & 130.1 & 119.6 & 142.7 \\
\hline \hline Laguna & 120.8 & 129.4 & $\mathbf{1 4 1 . 7}$ & 122.6 & 113.5 & 95.9 & 97.2 & 128.6 & 137.2 & 123.3 & 104.4 & 97.0 \\
\hline \hline Orleães & 167.2 & $\mathbf{1 6 7 . 8}$ & 156.7 & 93.5 & 87.3 & 78.5 & 89.9 & 116.6 & 135.4 & 131.5 & 107.2 & 137.6 \\
\hline \hline
\end{tabular}

Tab. 6.1 - Precipitação Mensal Média (em mm, sendo os valores em verde os máximos e em laranja os mínimos. (fonte: Séries Históricas da EPAGRI e CLIMERH de 1924 a 2004) 
O Gráfico a seguir representa as precipitações pluviométricas médias mensais nas estações da tabela acima.

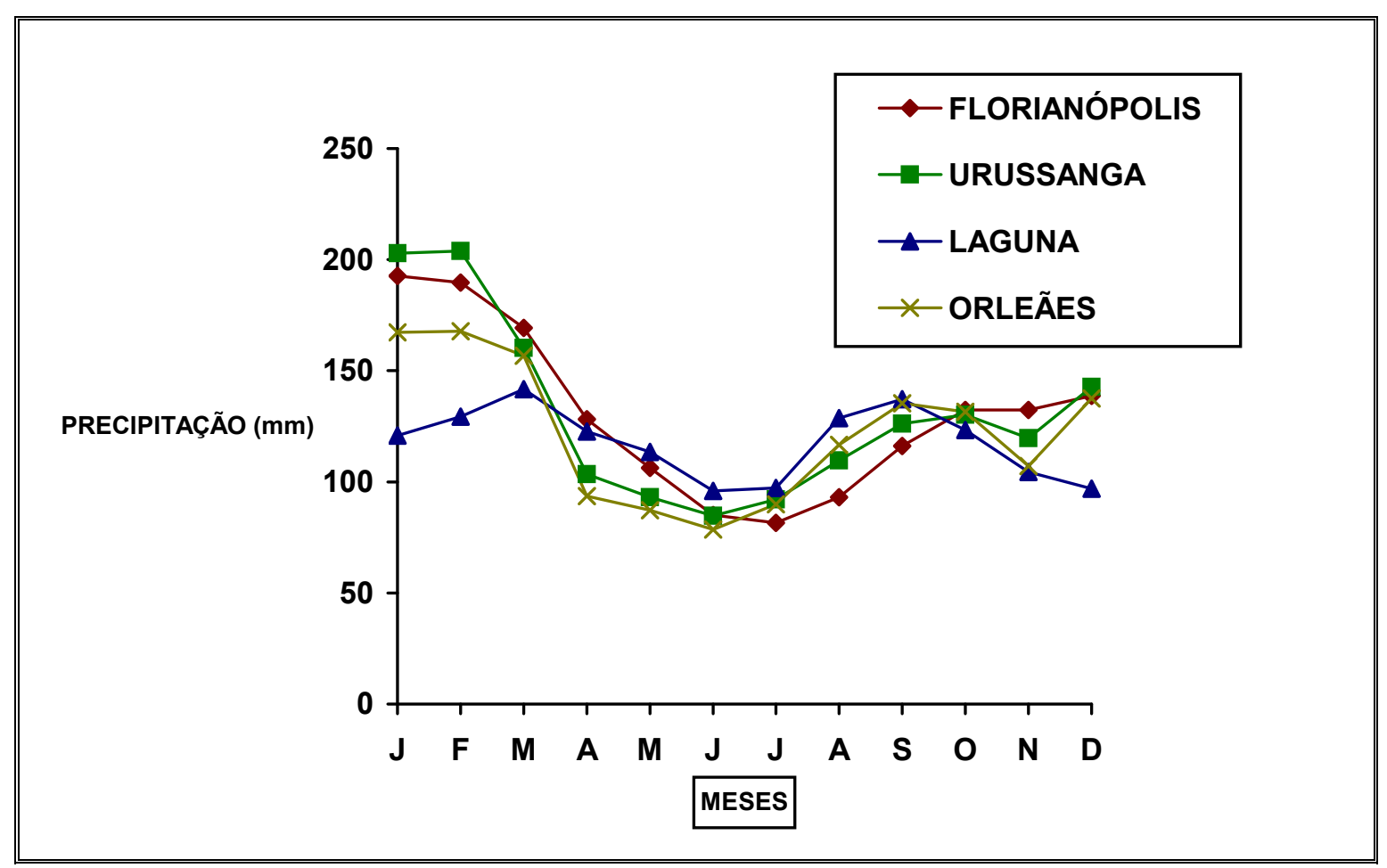

Graf. 6.1 - Precipitação Mensal Total (em mm)

O regime pluviométrico da região pode ser definido da seguinte maneira: meses de outubro a março ocorrem as maiores médias mensais e meses de maio a agosto representam as menores médias mensais (Graf. 6.1).

A precipitação total anual média para cada estação meteorológica de acordo com as séries históricas, encontra-se na tabela abaixo.

\begin{tabular}{|c|c|}
\hline Estação & Precipitação Anual total (mm) \\
\hline \hline Florianópolis & 1565,4 \\
\hline \hline Urussanga & 1568,4 \\
\hline \hline Laguna & 1411,6 \\
\hline \hline Orleães & 1469,2 \\
\hline \hline
\end{tabular}

Tab.6.2 - Precipitação anual total (em mm)

Podemos estabelecer que a média pluviométrica para região está em torno de 1503,65 $\mathrm{mm}$ por ano. 


\subsection{2 - Temperatura}

A temperatura atmosférica apresenta-se como um fator de grande importância na pesquisa de águas termais e termo-minerais, pois considera-se termal a água que apresenta a temperatura de emergência $4^{\circ} \mathrm{C}$ mais elevada que a temperatura média anual do local onde emerge.

A temperatura atmosférica é definida como o estado térmico do ar atmosférico, ou seja, o estado de frio ou calor da atmosfera.

As temperaturas médias mensais, que têm influência direta na evapotranspiração e conseqüentemente no regime hidrológico local, são as seguintes, conforme mostra a tabela abaixo.

Segundo o ATLAS DE SANTA CATARINA, as amplitudes térmicas são moderadas para a região. A temperatura máxima das médias mensais do período considerado ocorreu no mês de janeiro com valores próximos de $30,0^{\circ} \mathrm{C}$. A temperatura mínima das médias foi a do mês de junho com valores de cerca de $16,0^{\circ} \mathrm{C}$.

\begin{tabular}{|c|c||c||c||c|c|c|c|c|c||c||c|c|}
\hline \begin{tabular}{|c|} 
Mês \\
Estação
\end{tabular} & jan & fev & mar & abr & mai & jun & jul & ago & set & out & nov & dez \\
\hline \hline FLORIANÓPOLIS & 24.4 & 24.6 & 24 & 21.8 & 19.4 & 17.1 & 16.3 & 16.8 & 17.8 & 19.4 & 21.2 & 23 \\
\hline \hline URUSSANGA & 23.6 & 23.5 & 22.6 & 19.8 & 16.9 & 14.6 & 14.3 & 15.5 & 17 & 18.9 & 20.8 & 22.6 \\
\hline \hline LAGUNA & 23.7 & 23.9 & 23.1 & 20.9 & 18.4 & 16.5 & 15.7 & 16.2 & 17 & 18.6 & 20.4 & 22.4 \\
\hline \hline ORLEÃES & 23 & 23.1 & 21.6 & 19 & 16.1 & 14.4 & 14.2 & 14.9 & 16.5 & 18.9 & 20.5 & 22.4 \\
\hline
\end{tabular}

Tab. 6.3 - Temperatura média mensal $\left(\mathrm{em}^{\circ} \mathrm{C}\right)$. Fonte: Séries Históricas da EPAGRI e CLIMERH de 1924 a 2004. Em Vermelho as Máximas e em Azul as mínimas.

O gráfico a seguir correspondente à variação média das temperaturas para estas estações meteorológicas. 


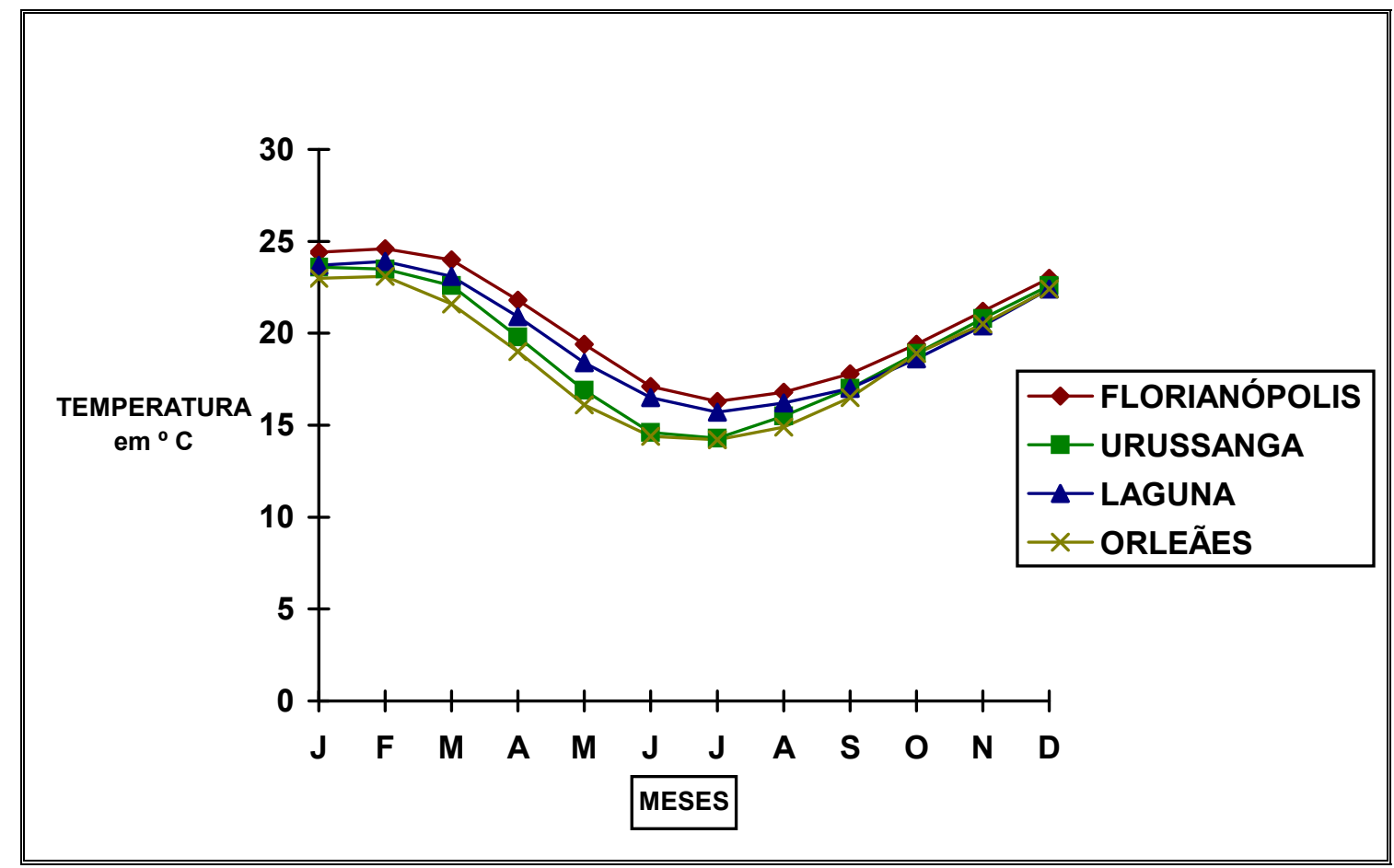

Graf. 6.2 - Temperaturas medias mensais $\left({ }^{\circ} \mathrm{C}\right)$. Fonte: Séries Históricas da EPAGRI e CLIMERH de 1924 a 2004.

A amplitude térmica não é muito acentuada, em torno de $8,7^{\circ} \mathrm{C}$, o que dá uma sensação térmica muito confortável e possibilita períodos de clima ameno para as pesquisas.

Os meses de temperatura mais elevada são dezembro, janeiro e fevereiro, os meses mais frios são junho, julho e agosto. A temperatura média anual está em torno de $20,2^{\circ} \mathrm{C}$.

\subsection{3 - Evapotranspiração Potencial}

Entende-se por evapotranspiração como sendo a perda de água do sistema hídrico pelo conjunto dos processos de evaporação de água do solo e transpiração vegetal.

A evapotranspiração potencial é uma conseqüência direta da variação de temperatura e calculada pelo Método de Thornthwaite.

A maior taxa de evaporação na região ocorre no verão onde o mês mais crítico é janeiro, que também é o que detém a maior taxa de umidade do ar 
com média de $160 \mathrm{~mm} /$ mês. Por outro lado, o mês mais seco e com menos evapotranspiração é o mês de junho com média de $30 \mathrm{~mm} / \mathrm{mês}$. A evapotranspiração média anual da região é de $1070 \mathrm{~mm} /$ ano.

Os dados obtidos nas quatro Estações Meteorológicas levam a concluir que nos meses de outubro a dezembro a evapotranspiração potencial é mais elevada na Estação de Itajaí devido principalmente a continentalidade e aos ventos predominantes provenientes do quadrante Noroeste serem mais aquecidos.

\subsection{4 - Correlação entre Precipitação e Evapotranspiração Potencial}

Combinando-se os valores de precipitação média mensal e a evapotranspiração potencial dos dados obtidos nas quatro estações meteorológicas, temos uma correlação das informações sobre o excedente hídrico ou o déficit local que sugere os seguintes resultados:

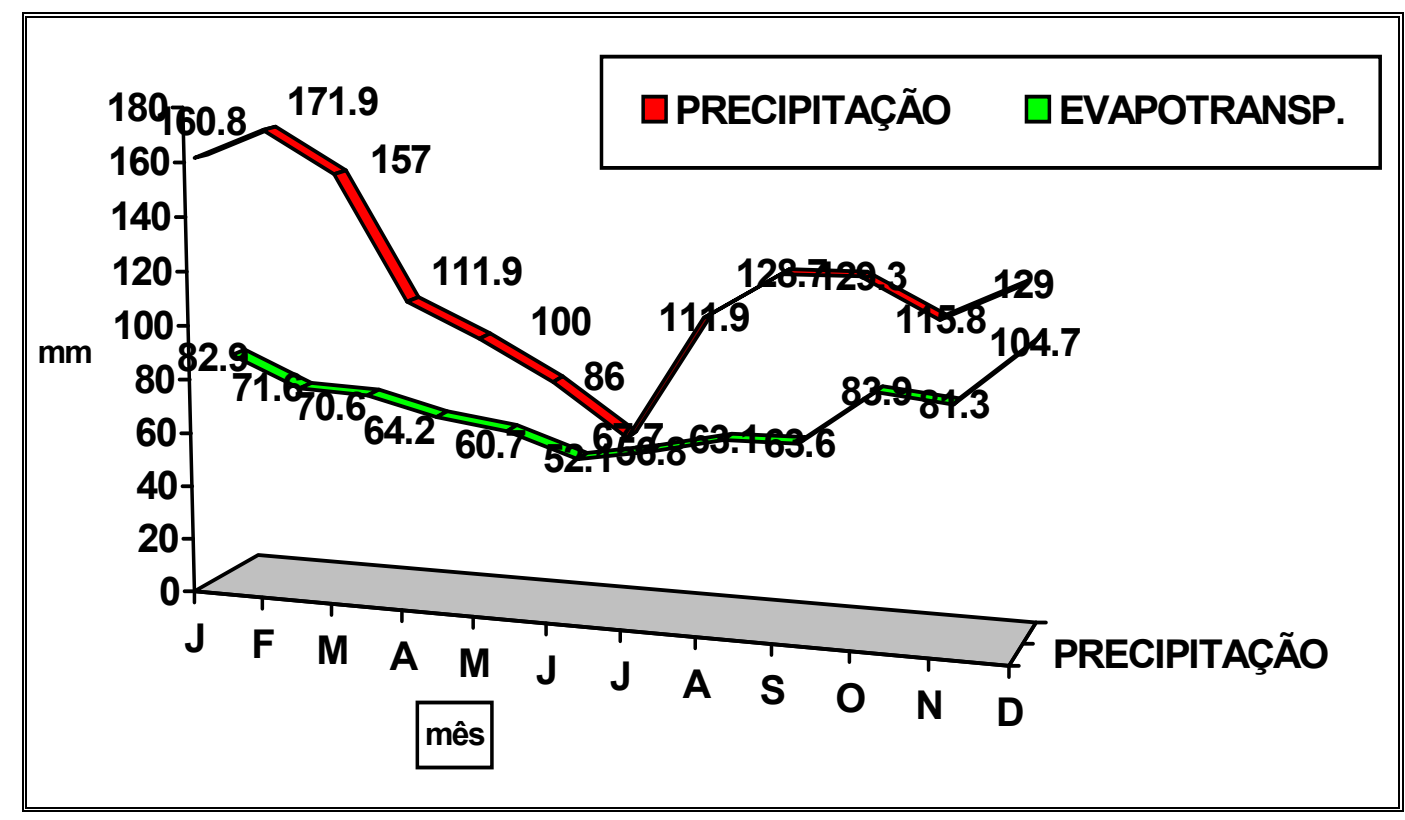

Graf.6.3 - Evapotranspiração potencial x precipitação total mensal na 4 estações meteorológicas. 
Em toda a região predomina o excedente hídrico sobre o déficit. Ocorre abundância de chuvas significando que há uma boa fração da água da chuva, que se infiltra no solo, atravessa a zona das raízes e vai alimentar o aqüífero freático, constituindo-se como reserva de água subterrânea (Fig 6.2).

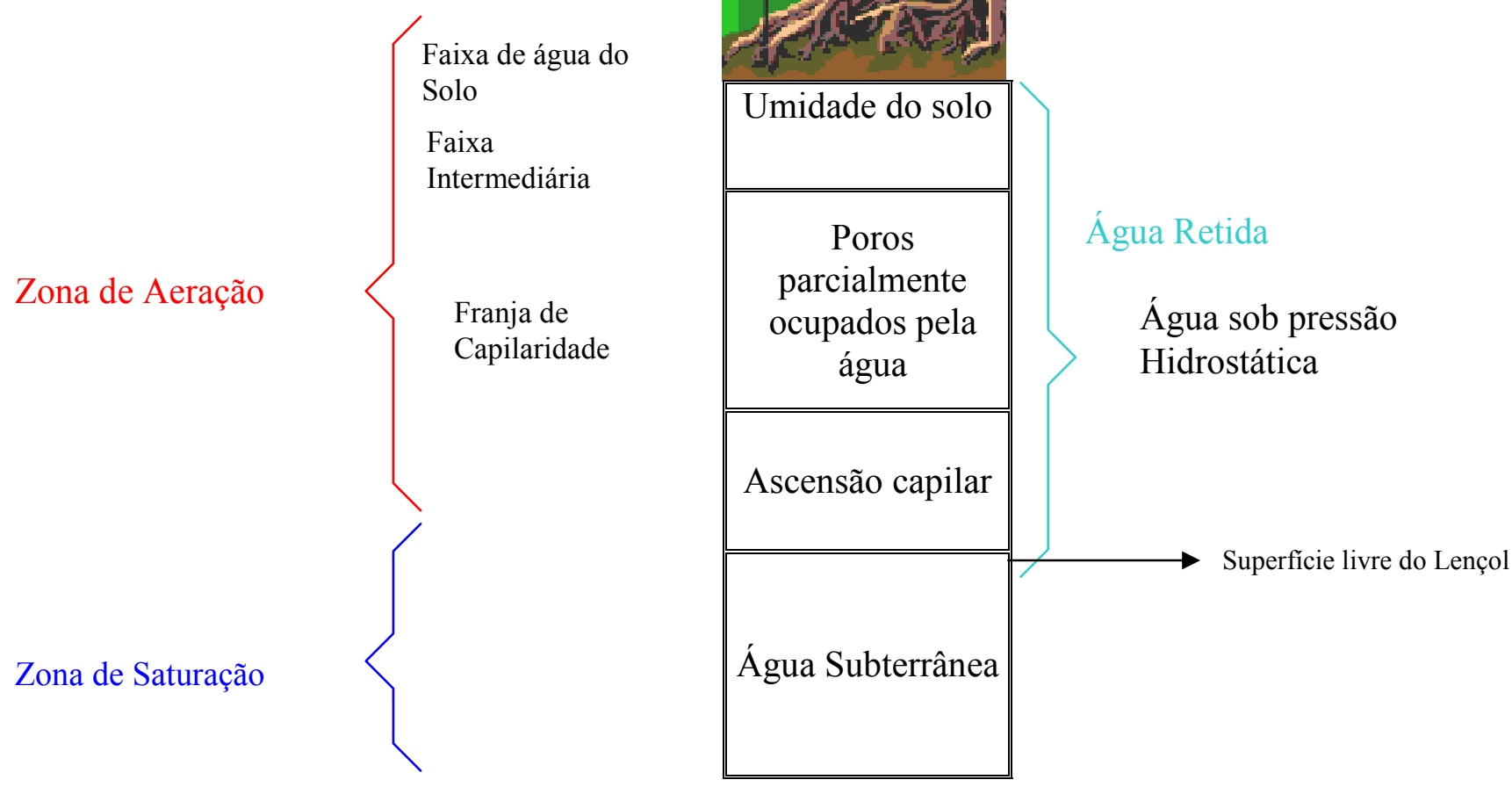

Fig.6.2 - Disposição da água nos diferentes níveis de circulação

As informações acima permitem classificar o clima utilizando-se o Método de THORTHWAITE (1955) para cada Estação Meteorológica, conforme descrito no item seguinte.

\subsection{5 - Tipos Climáticos regionais}

Segundo THORTHWAITE (op. cit.), a área possui classificação climática do tipo $\mathbf{B}_{2} \mathbf{B}_{3}{ }^{\prime}$ ra' onde $\mathbf{B}_{2}$ significa que a região é úmida com Índice Hídrico entre $40 \%$ e $60 \% ; \mathbf{B}_{3}{ }^{\prime}$ significa que é mesotérmico com Índice de Evapotranspiração potencial entre 885 e 997 mm anuais; ra' significa que possui baixo Índice de aridez e que a evapotranspiração no verão não ultrapassa 48\%. 


\section{2 - Geomorfologia}

A região é caracterizada por um relevo intermediário entre o montanhoso, acidentado, formado sobre rochas da Suíte Intrusiva Pedras Grandes que compõem parte da chamada "Serras do Leste Catarinense" e a Planície Costeira com grandes regiões planas originadas por sedimentação flúvio-marinha no quaternário. Destaca-se no contexto geomorfológico o relevo escarpado relacionado a porção norte das serras do Leste Catarinense, com cotas variando de próximo de $0 \mathrm{~m}$ até cerca de $1200 \mathrm{~m}$.

As Serras do Leste Catarinense são caracterizadas pela seqüência de serras dispostas de forma subparalela. Estendem-se na direção Norte - Sul, desde as proximidades do município de Joinville até o município de Laguna, com sentido predominante de Noroeste-Sudoeste, e apresentam uma gradação mais baixa em relação ao litoral, onde terminam em pontais, penínsulas e ilhas. As altitudes variam de próximo de $0 \mathrm{~m}$, no nível do mar (NM) próximo ao litoral, até cerca de $900 \mathrm{~m}$ na porção mais ocidental, com algumas exceções encontradas nas serras do Tabuleiro e Anitápolis, aonde as cotas altimétricas ultrapassam os 1200 m.

Segundo ALMEIDA (1948), numa análise acurada das cotas topográficas e do contexto lito-estrutural, pode-se desdobrar, coadjuvados pela hidrografia regional, estes grandes elementos morfológicos, em seis unidades, a saber:

\footnotetext{
$>\quad$ Planalto Cristalino;

$>$ Serras Litorâneas;

$>\quad$ Planalto Sedimentar;

$>\quad$ Planalto de Lages;

$>\quad$ Planalto Basáltico;

$>\quad$ Planície Costeira.
}

A área estudada encontra-se encravada na unidade denominada Serras Litorâneas, próxima a transição entre a planície costeira e a Serra. (Foto 6.1) 


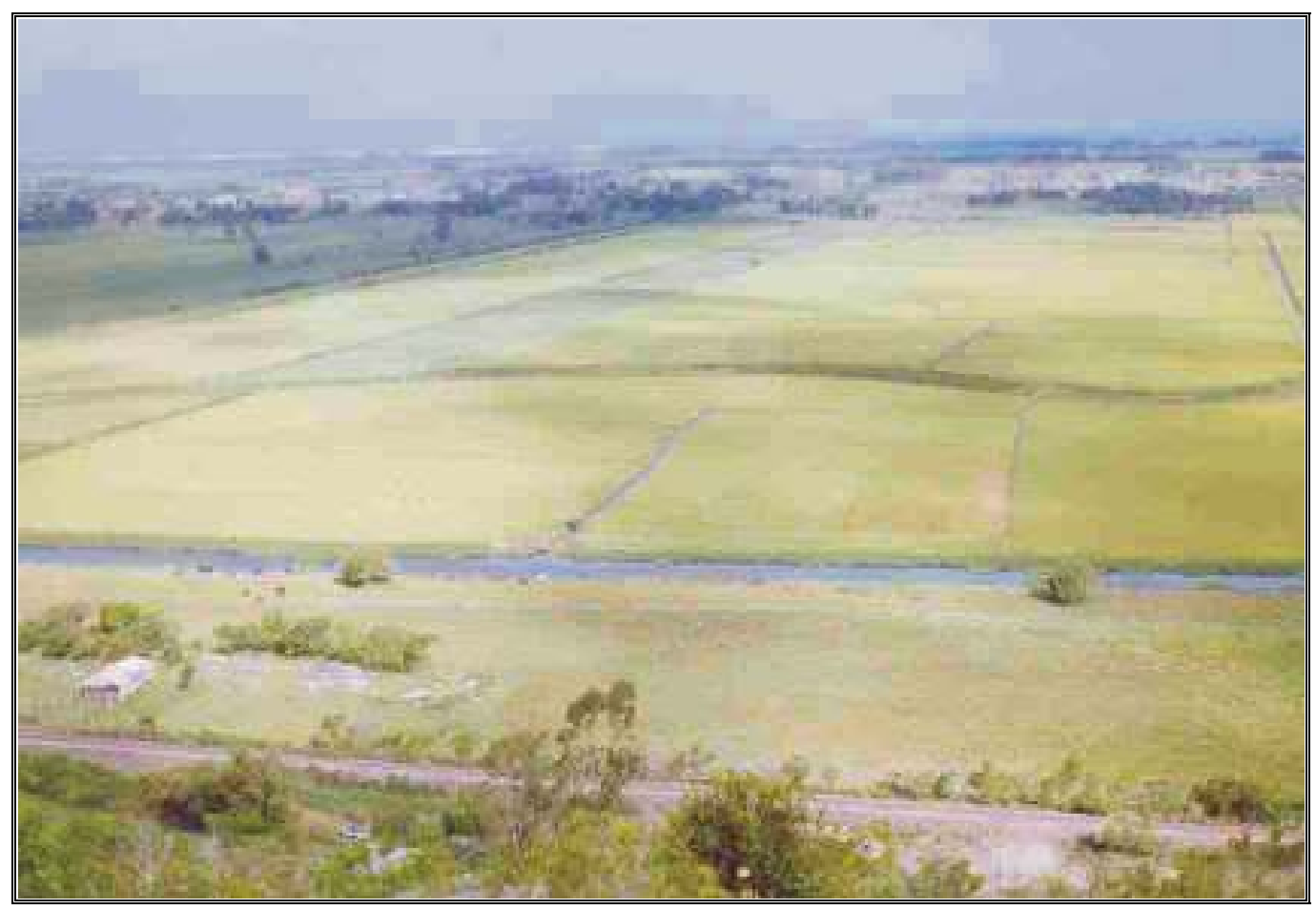

Fig. 6.3 - Vista da Planície Costeira a partir da serra do Leste Catarinense. A foto foi tirada no extremo sul da área, próximo ao município de Tubarão.

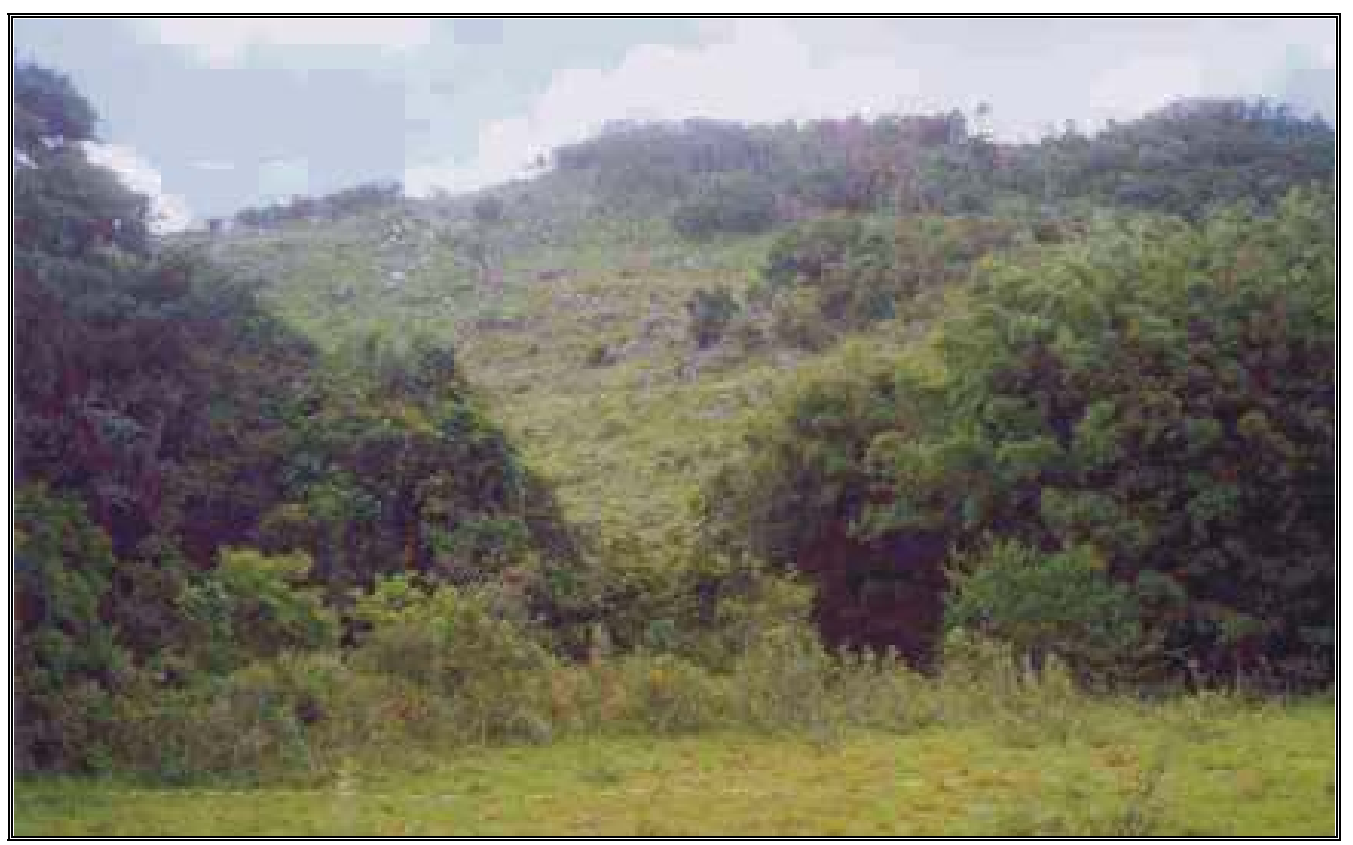

Fig. 6.4 - Vista do afloramento da Suíte Intrusiva Pedras Grandes a partir da Planície Costeira. A foto foi tirada na porção central da área, próximo ao município de Imbituba. 


\section{3 - Hidrografia}

As bacias hidrográficas da região pertencem ao sistema de drenagem da vertente do Atlântico.

Rios em sua definição são cursos naturais de água doce, com canais definidos e fluxo permanente ou sazonal para um Oceano, lago ou outro rio. Dada a sua capacidade de erosão, transporte e deposição, os rios são os principais agentes de transformação da paisagem, agindo de forma a modelar o terreno.

A morfologia dos canais fluviais é controlada por uma série de fatores autocíclicos, que são próprios da bacia de drenagem e alocíclicos que estão ligados aos fatores regionais, com relações bastante complexas. São os fatores autocíclicos a descarga, a carga de sedimentos transportada, a largura e a profundidade do canal, a velocidade do fluxo, a declividade, a rugosidade do leito, a cobertura vegetal das margens e ilhas. Os fatores alocíclicos são o clima (pluviosidade e temperatura) e geológicos (litologia, topografia e tectônica (falhamentos, dobramentos, etc.).

No caso da região estudada o padrão de drenagem observada na região entorno é a dendrítica, com paralelismo observado em alguns pontos, quando torna-se uma variação do tipo pinado. Sendo o padrão dendrítico o mais comumente encontrado, é caracterizado por um arranjo de drenagem semelhante à distribuição dos galhos de uma árvore e ocorre quando a rocha dos substratos apresentam uma certa homogeneidade litológica e estrutural, o paralelismo é devido a alinhamentos estruturais regionais, no caso, falhamentos, ativados no ciclo Brasiliano.

\section{4 - Vegetação}

A vegetação tem papel importante no Ciclo Hidrológico, pois contribui significativamente nos processos de evapotranspiração. A água superficial é absorvida em parte pelas raízes das plantas e acaba voltando a atmosfera pela transpiração das folhas. O desenvolvimento vegetal está intimamente vinculado às 
características do ambiente onde se encontram, sendo estes fatores a umidade, a luminosidade, calor, fertilidade do solo, entre outros, que acabam caracterizando a vegetação ao contexto ambiental.

A vegetação predominante na área é a Floresta Ombrófila Densa, também conhecida como Mata Atlântica. Compreendem as planícies e serras da costa catarinense, com ambientes marcados intensamente pela influência oceânica, traduzida em elevado índice de umidade e baixa amplitude térmica. Este tipo de clima é propício ao desenvolvimento de uma floresta com fisionomia e estruturas peculiares, com grandes variedades de formas de vida e elevado contingente de espécies endêmicas.

A vegetação que se destaca nestes ambientes são de floresta pluvial da costa atlântica, com uma biodiversidade muito grande, sendo encontradas espécies como a Canela, Guamirim, Bicuíba, Perobas, Cedro, Pau-d’óleo, Figueira, Olandi, Palmiteiro, Jamboleiro, entre outras, conforme a sistematização adotada no Atlas de Santa Catarina (GAPLAN, 1986) e a Classificação Fitoecológica do Projeto RADAM-BRASIL (VELOSO \& GÓES FILHO, 1982).

Segundo KLEIN (1978), toda a área encontra-se dentro dos limites da Floresta Ombrófila Densa, pertencendo a tipologia da Floresta Tropical do Litoral e Encostas Centro-Norte, onde as árvores mais importantes em termos de mata nativa são: a canela-preta (Ocotea catharinensis), formando troncos grossos e largas copas, é sem dúvida, a árvore principal, não só pela abundância, mas também pelo seu valor comercial; seguem em importância a canela-sassafrás (Ocotea pretiosa) além da peroba-vermelha (Aspidosperma olivaceum), da laranjeira-do-mato (Sloanea guianensis), do guamirim-chorão (Calyptranthes strigipes) do pau-óleo (Copaifera trapizefolia), do palmiteiro (Euterpes edulis), maria-mole (Guapira opposita), a canela-fogo (Cryptocarya aschersoniana), entre outras, todas muito comuns na área. Segundo este autor, esta vegetação era composta por uma formação vegetal exuberante, complexa, composta por densas comunidades arbóreas de diversos estratos e por espécies diferentes. Entretanto, percebe-se na área estudada que a cobertura vegetal original já sofreu sensíveis alterações. Na época da colonização pela exploração da madeira; mais tarde pela agricultura e monocultura (banana, pinus, palmital, etc). 


\section{$6.5-$ Solos}

Os solos da região estudada podem ser divididos nestas principais categorias:

Areias Quartzosas Marinhas: São solos associados a sedimentos arenoquartzosos não consolidados que apresentam em sua estrutura uma textura com mais de $80 \%$ de grãos de quartzo.

> Dunas: Em definição é muito próxima às Areias quartzosas, porém sofreram uma seleção por ação eólica, formando depósitos na forma de outeiros. A granulometria em geral é fina, mas pode variar conforme a intensidade do vento na região onde ela se deposita.

> Cambissolo: No Sistema Brasileiro de Classificação de Solos, é a classe de solos constituídos por material mineral que tem como características diferenciais argila de atividade baixa e horizonte $\mathrm{B}$ incipiente $(\mathrm{Bi})$, imediatamente abaixo de qualquer tipo de horizonte superficial, sem apresentar, contudo, os requisitos estabelecidos para enquadramento nas classes dos Vertissolos, Chernossolos, dos Plintossolos ou dos Gleissolos. Apresentam seqüência de horizontes $\mathrm{A}$ ou hístico, $\mathrm{Bi}, \mathrm{C}$, com ou sem $\mathrm{R}$. Por definição, o horizonte hístico do Cambissolo deve apresentar menos de 40 $\mathrm{cm}$ de profundidade. Não são incluídos nesta classe os solos com horizonte A chernozêmico e com horizonte $B$ incipiente com alta saturação por bases e argila de atividade alta (Fonte: www.embrapa.br).

> Glei Humico: No Sistema Brasileiro de Classificação de Solos, é a classe de solos hidromórficos constituídos por material mineral que apresentam horizonte glei dentro dos primeiros $50 \mathrm{~cm}$ de profundidade, ou a profundidade entre 50 e $125 \mathrm{~cm}$ caso esteja. 1) imediatamente abaixo de horizontes A ou $E$ (que podem ser gleizados ou não); e 2) precedido por qualquer tipo de horizonte $\mathrm{B}$, exceto plânico e plíntico, e/ou $\mathrm{C}$ com presença de mosqueados abundantes com cores de redução; sem apresentar, contudo, os requisitos para enquadramento nas classes dos Vertissolos, dos Espodossolos, dos Planossolos, dos Plintossolos ou dos Organossolos. Em condições naturais, 
são solos mal ou muito mal drenados, que apresentam sequencias de horizontes A-Cg, A-Big-Cg, A-Bi-Cg, A-Btg-Cg, A-Bt-Cg, A-E-Btg-Cg, A-Eg$\mathrm{Btg}-\mathrm{Cg}, \mathrm{Ag}-\mathrm{Cg}, \mathrm{H}-\mathrm{Cg}$. Estes solos se caracterizam pela forte gleização. (Fonte: EMBRAPA - 2005).

> Solos Orgânicos: constituídos essencialmente por resíduos orgânicos em vários estágios de decomposição depositados sob condições anaeróbicas em locais abaciados. Têm densidade muito baixa, o que thes confere um grau de trafegabilidade muito reduzido. Sua composição orgânica os predispõem sobremaneira à subsidência (rebaixamento superficial) quando drenados, em função da contração de volume por remoção de água, ao que se segue intensa mineralização. (Fonte: www.embrapa.br).

> Podzol: unidade que agrupa solos que apresentam horizonte diagnóstico subsuperficial (B podzol ou $B$ espódico) precedido de horizonte $E$ albico (claro) ou mesmo em seqüência ao horizonte A. São normalmente arenosos, mas o horizonte $B$ é espódico escuro, em razão do acúmulo de matéria orgânica e óxidos de Al e Fe (Fonte: www.embrapa.br).

> Podzólico vermelho-amarelo: O conceito básico dos solos podzólicos é que esses solos apresentam um horizonte B textural. A utilidade do conceito do horizonte $\mathrm{B}$ textural, definido como correspondente ao horizonte argílico do SOIL TAXONOMY, nos trópicos, é questionada por outros autores. O SOIL TAXONOMY define o horizonte argílico como sendo um horizonte iluvial onde se acumulam argilas silicatadas pela iluviação. Isso não inclui a formação de argila no horizonte $B$, nem a presença do que é herdado do material de origem. (HARIDASAN, 1994).

Solos Litólicos: Uma das classes do Sistema Brasileiro de Classificação de Solos. Corresponde, no antigo Sistema, à classe dos Solos Litólicos. São solos muito rasos, não alagados, onde a rocha de origem está a menos de $50 \mathrm{~cm}$ da superfície. Suas propriedades são inteiramente dominadas pelas da rocha de origem. Tipicamente, possuem seqüência de horizontes A-C-R, onde $\mathrm{R}$ representa a rocha. São semelhantes aos Entissolos da taxonomia dos solos. 


\section{7 - TERMALISMO E MODELOS GENÉTICOS APLICÁVEIS}

"Eu acrescentaria como conjectura, que a causa positiva do verdadeiro aquecimento pode proceder das partes mais profundas da região subterrânea, as quais situam-se abaixo de lugares em que homem algum teve oportunidade de habilidade para cavar, parece provável a mim, que nessas ainda impenetradas entranhas da terra, há grandes depósitos ou verdadeiro fogo, ou lugares consideravelmente quentes, ou em algumas regiões de ambos; a partir desses repositórios (se é que posso chamá-los assim) ou depósitos de calor hipogênico, essa qualidade é comunicada, especialmente por canais subterrâneos, fendas, fibras ou outros veículos, para as partes menos profundas da terra"

Robert Boyle in "Of the temperatures of the subterraneal regions as to heat and cold"

Oxford, 1671

Os campos de água quente em Santa Catarina são constituídos por reservatórios a uma temperatura entre os $30^{\circ} \mathrm{C}$ e os $45^{\circ} \mathrm{C}$. Um campo geotérmico típico tem como principais características:

uma fonte de calor de grande capacidade;

$>$ uma zona de rocha fraturada (permeável) constituindo o reservatório geotérmico;

> uma zona de cobertura de rochas pouco permeáveis na parte superior do reservatório;

$>$ um regime hidrológico favorável, associado a zonas de fratura que permitem a infiltração da água da chuva;

A fonte do calor é, geralmente, constituída por uma intrusão magmática com temperatura elevada (superior a $600^{\circ} \mathrm{C}$ ). $\mathrm{O}$ calor, produzido por esta fonte, é conduzido através das fraturas nas rochas que formam a base do reservatório, e vai aquecer a água que se encontra dentro do reservatório poroso ou das fraturas. A água, proveniente das chuvas, penetra em profundidade através das 
zonas de fratura, e aquece durante a circulação através das rochas aquecidas que constituem o reservatório. Este tipo de fonte é freqüente em zonas de vulcanismo recente (Açores, Japão e América Central).

A ascensão da água quente, com eventual formação de fontes naturais, depende da existência de fraturas na cobertura do reservatório. Este pode ser constituído por rochas porosas, como é o caso dos tufos vulcânicos, ou por rocha fissurada, a água, por convecção sobe até a superfície por apresentar menor densidade que as águas frias. A cobertura é formada por rochas impermeáveis ou com permeabilidade muito baixa. O regime hidrológico é um fator importante na caracterização dos campos geotérmicos determinando a possibilidade da sua exploração industrial, pois dele depende a recarga do reservatório.

$\mathrm{Na}$ Europa, existem campos de água quente na região do Lago Baikal, na ex-URSS, e na Planície Húngara.

O vulcanismo, a atividade sísmica, os fenômenos de metamorfismo e de orogenia, são alguns dos fenômenos que são controlados pela transferência e geração de calor. De fato, o balanço térmico da Terra controla a afetividade na litosfera, na astenosfera assim como no interior do planeta.

O conhecimento de que o calor aumentava em relação com a profundidade já era conhecida na Europa do séc. XVII, a partir de observações feitas em minas de carvão, onde os mineradores agüentavam temperaturas de até $50^{\circ} \mathrm{C}$. A primeira determinação científica desse fato se deu por Willian Thomson (Lord Kelvin), que encontrou na relação entre temperatura $x$ profundidade o valor de $68 \times 10^{-3} \mathrm{~W} / \mathrm{m}^{2}$.

Somente na década de 30 do séc. $X X$, pesquisadores como Edward Bullard e Francis Birch, perceberam a importância desse fluxo de calor para a determinação da evolução tectônica e petrológica da crosta terrestre, tornando a investigação sistemática e modernizando os meios de obtenção de dados.

As primeiras compilações de medidas de densidade de fluxo geotérmico foram apresentadas por Birch em 1954, em um total de 63 medidas distribuídas no continente e oceano, atualmente esse número ultrapassa os 10.000 . O histórico de medidas de densidade de fluxo goetérmico no Brasil só se inicia na década de 1970 do séc. XX com medidas feitas por UYEDA \& WATANABE (1970) 
e MEISTER (1973). Com CARVALHO \& VACQUIER (1977), ARAÚJO (1977), FONTES (1980), CARVALHO (1981) e HAMZA (1982ª), é feita uma compilação de dados geotérmicos no país, em um total de 114 medidas.

Convém explicar que os reservatórios de água subterrânea são unidades hidrogeológicas caracterizadas por parâmetros dimensionáveis (extensão, espessura e geometria), que são impostos pela geologia, estratigrafia e tectônica; por parâmetros hidrodinâmicos (transmissividade (T), armazenamento ou porosidade efetiva (nef)), temperatura, que dependem dos padrões faciológicos; pelas condições de recarga e descarga; e pelas variáveis de estado que descrevem a situação do aqüífero em cada instante (superfície piezométrica, importância das reservas, aspecto de qualidade, condições de exploração, etc.).

Nos terrenos pertencentes ao embasamento cristalino, de idade précambriana, as possibilidades termo-hidrogeológicas são ligadas a características locais e excepcionais como zonas fraturadas profundas.

A gênese das águas termais é genericamente resumida por GONSALVES (1936) onde uma de suas hipóteses diz que

"A água da chuva, infiltrando-se pelo solo, à medida que desce para o centro da terra, vai se aquecendo de $1^{\circ}$ (grau) centígrado para cada $35 \mathrm{~m}$ de profundidade. Chega a um ponto que os vapores formados em alta tensão sobem por fendas que encontram, facilitando a decomposição e, já sob o estado de agregação líquido, dissolvendo sais diversos, surge por fim, na superfície da terra com a forma de água mineral".

LINDGREN (1933), diz que ocorrem águas nos próprios magmas em proporções notáveis, vindo a constituir a "água mineral". RANKANA \& SAHANA (1968), afirmaram:

"a água subterrânea misturada com água juvenil, passa a formar parte das emanações vulcânicas e das fontes termais; as águas magmáticas profundas se caracterizam por seu conteúdo notável em metais pesados, enquanto que a concentração desses metais nas águas de origem superficial (= vadosa) é pequena ou depreciável". 
O vulcanismo, a atividade sísmica, os fenômenos de metamorfismo e de orogenia, são alguns dos fenômenos que são controlados pela transferência e geração de calor. De fato, o balanço térmico da Terra controla a atividade na litosfera, na astenosfera assim como no interior do planeta.

O calor que chega à superfície da Terra tem duas fontes: o interior do planeta e o sol. A energia proveniente do sol e recebida pela Terra é cerca de $4,0 \times 10^{2} \mathrm{~J} / \mathrm{s} / \mathrm{m}^{2}$. Uma parte desta energia é reenviada para o espaço. A energia proveniente do interior do planeta é de aproximadamente $8,0 \times 10^{-2} \mathrm{~J} / \mathrm{s} / \mathrm{m}^{2}$. Se aceitarmos que o sol e a biosfera têm mantido a temperatura média, à superfície do planeta, com pequenas flutuações (entre $15^{\circ} \mathrm{C}$ e $25^{\circ} \mathrm{C}$ ), então o calor proveniente do interior do planeta tem condicionado a evolução geológica do mesmo, isto é, tem controlado a tectônica de placas, a atividade ígnea, o metamorfismo, a geração de cadeias montanhosas, a evolução do interior do planeta incluindo a do seu campo magnético (COX et alli 1986).

A condução de calor é regida pela lei de Fourier que estabelece que o fluxo de calor $q$, num ponto do meio, é proporcional ao gradiente de temperatura nesse ponto, isto é:

$$
\vec{q}=-K \vec{\nabla} T
$$

Onde $\mathrm{K}$ é a condutibilidade térmica do meio. Esta é uma propriedade física do material e é uma medida da capacidade do material para conduzir calor. O fluxo de calor é expresso em $\mathrm{W} \mathrm{m}^{-2}$, no sistema internacional, e a condutibilidade térmica em $\mathrm{W} \mathrm{m} \mathrm{m}^{-1} \mathrm{~K}^{-1}$; no sistema c.g.s. o fluxo de calor vem expresso em cal $\mathrm{cm}^{-2} \mathrm{~s}^{-1}$ e a condutibilidade térmica em cal $\mathrm{cm}^{-1} \mathrm{~s}^{-1} \circ \mathrm{C}^{-1}$ (para fazermos a conversão lembrar que $1 \mathrm{cal}=4,187 \mathrm{~J}$ ).

A expressão abaixo pode ser usada para determinar a variação da temperatura com a profundidade.

$$
T=T_{s}+\frac{q_{s}}{K} z-\frac{\rho Q}{2 K} z^{2}
$$


Considerando que o calor é transportado, principalmente, por condução. A curva temperatura x profundidade é designada por "geotérmica". Se considerarmos os seguintes valores:

$$
\begin{aligned}
& 0=\mathrm{Ts}^{\circ} \mathrm{C} \\
& 70=\mathrm{qs} \mathrm{mW} \mathrm{m}{ }^{-2} \\
& 3300=\mathrm{kg} \mathrm{m}^{-3} \\
& 106.2 \mathrm{x}=\mathrm{Q}-12 \mathrm{~W} \mathrm{~kg}^{-1} \mathrm{e} \\
& 4=\mathrm{KW} \mathrm{m}^{-1} \mathrm{~K}^{-1},
\end{aligned}
$$

Obtém-se a curva mostrada na figura abaixo, juntamente com as curvas de fase do basalto.

Uma análise da figura mostra que a profundidades superiores a 100 $\mathrm{km}$, o manto deveria apresentar uma fusão significativa e que para profundidades superiores a $150 \mathrm{~km}$ todo o manto devia estar em fusão.

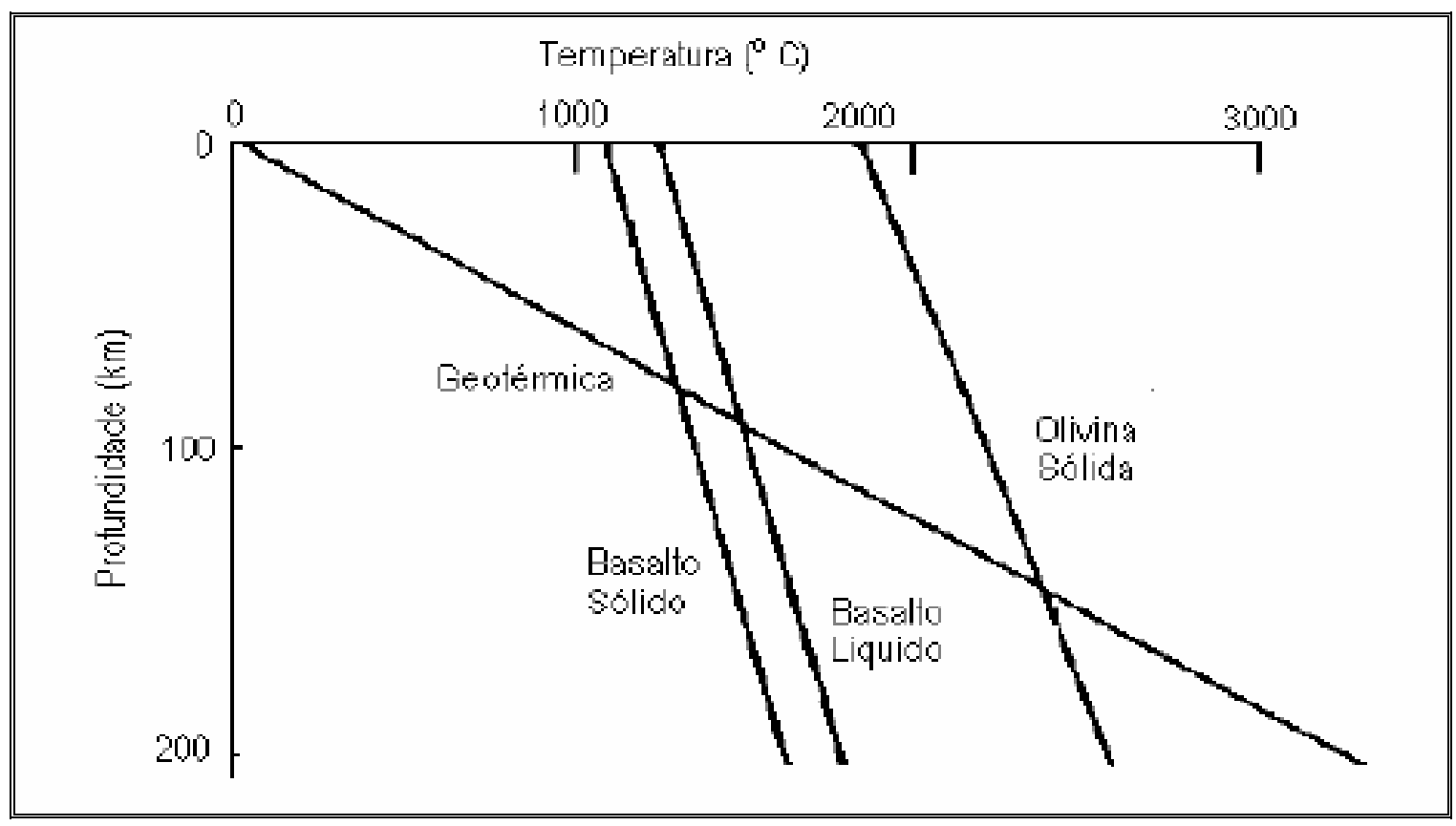

Fig. 7.1- Relação entre temperatura e profundidade. (Fonte: MIRANDA et alli, 2005) 
Estas previsões não estão de acordo com as informações obtidas a partir do estudo da propagação das ondas sísmicas, o que se pode concluir que o modelo de condução de calor não prevê corretamente o perfil de temperaturas no manto. Embora o modelo de condução falhe na previsão das temperaturas para o manto inferior, ele apresenta um sucesso considerável quando aplicado à parte mais exterior do planeta, isto é à crosta, onde o calor interno é produzido fundamentalmente por desintegração radioativa e transportado, até à superfície por condução.

\section{1 - Convecção}

Considerando uma camada de líquido aquecido na parte inferior e arrefecido na parte superior. Quase a totalidade dos fluidos, quando aquecidos, a sua densidade diminui devido à expansão. No caso considerado, teremos a parte superior da camada de líquido mais fria e, portanto, mais densa que a parte inferior. Esta situação é gravitacionalmente instável, tendendo o líquido mais arrefecido a descer e o mais aquecido a subir, isto é, geram-se correntes de convecção.

O movimento do fluido é devido às forças de impulsão originadas pelas variações da densidade. As forças que atuam sobre um elemento de fluido são:

- Forças devido ao gradiente de pressão;

- Gravidade;

- Forças de impulsão.

Para estas últimas deve-se levar em conta à variação da densidade do fluido. 

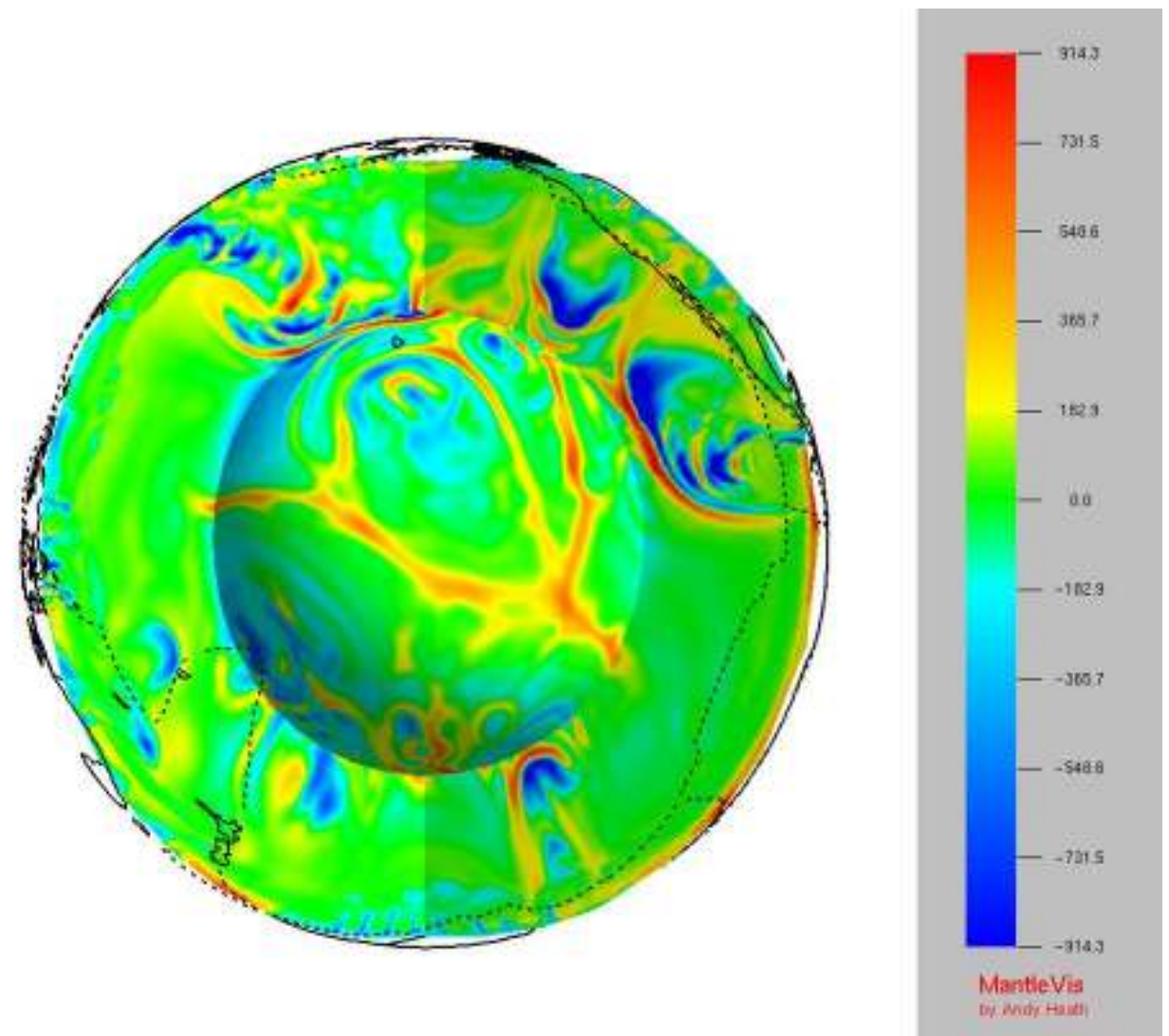

Fig. 7.2 - Modelo matemático de convecção do manto em 3D. Os azuis representam as temperaturas mais fria do que médias, temperaturas médias são as amarelas e verdes, e temperaturas mais quente do que médias do vermelho. (Fonte: Cardiff Marine Institute - http://www.earth.cf.ac.uk/research/geodynamics/picture1.jpg)

\section{2 - Fluxo de calor nos continentes}

A distribuição de fluxo de calor nos continentes é mais complexa que a observada nos oceanos. O fluxo medido nos continentes pode ter origens distintas: fusão ou intrusão magmática, extensão da crosta, erosão, geração de calor por elementos radioativos, entre outros.

Estes processos têm características físicas e escalas temporais distintas. Assim, os dados de fluxo nos continentes terão de ser analisados tendo em atenção a região em que foram obtidos.

POLYAK e SMIRNOV (1968) mostraram que os valores de fluxo estão relacionados com a idade tectônica da formação onde foram medidos: há uma diminuição exponencial do fluxo com o aumento da idade tectônica da região. 
Como a crosta continental contém uma quantidade significativa de fontes radioativas, elas contribuem para o fluxo medido. As observações mostram que, em regiões graníticas, há uma relação linear entre o fluxo de calor à superfície e o calor produzido por desintegração radiativa, pelas rochas superficiais. Estas observações podem ser explicadas por um modelo em que o calor produzido por desintegração radiativa decresce exponencialmente com a profundidade, isto é, da forma

$$
Q=Q_{S} e^{-z / h}
$$

Nesta expressão Qs representa a taxa de produção de calor pelas rochas superficiais e por unidade de massa, sendo $h r$ o valor da profundidade a que $\mathrm{Q} / \mathrm{e}=\mathrm{Q}$. O modelo prevê, ainda, que o fluxo de calor que chega à parte inferior da crosta, proveniente do interior do planeta é qm. Assim, o fluxo de calor à superfície será:

$$
q_{s}=q_{m}+\rho h_{r} Q_{s}
$$

O valor de $h r$ pode ser obtido a partir do declive da reta do gráfico da figura abaixo, sendo qm o valor dado pela intersecção da reta com o eixo vertical.

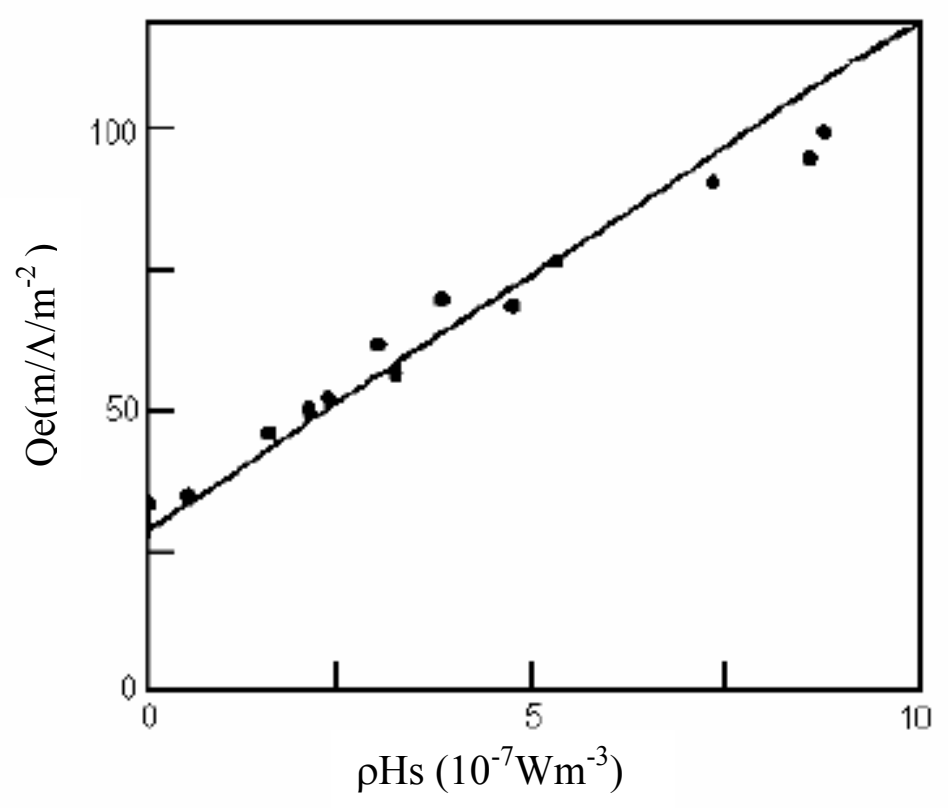

Graf. 7.1 - Valores médios para fluxo de calor (Fonte: MIRANDA et alli, 2005) 


\section{3 - Análise global da distribuição do fluxo de calor ao longo da Terra}

Desde os anos 60 que se têm compilado várias medidas de fluxo geotérmico efetuadas ao longo do globo. A partir da análise destas figuras pode concluir-se que, para os continentes existem desde valores muito baixos, da ordem de $1,1 \mu \mathrm{cal} \mathrm{cm}^{-2} \mathrm{~s}^{-1}$, nas regiões dos escudos continentais (com uma pequena dispersão), até valores mais elevados, que podem atingir os $2,8 \mu \mathrm{cal} \mathrm{cm} \mathrm{cm}^{-1}$, nas zonas orogênicas mais recentes.

Nas zonas não orogênicas pós e pré-câmbrianas, o valor do fluxo de calor é cerca de $1,5 \mu \mathrm{cal} \mathrm{cm}^{-2} \mathrm{~s}^{-1}$. Em resumo, o fluxo de calor nos continentes é tanto mais elevado quanto mais recente for a região e quanto mais ativa for a tectônica da região. É notável que existem algumas regiões onde o fluxo é "anormalmente" elevado, geralmente devido a campos geotérmicos locais como, por exemplo, toda a região do sudoeste da Austrália ou a planície húngara.

Sabendo que a litosfera mais recente é necessariamente menos espessa, é natural que possa existir uma relação entre o fluxo de calor medido à superfície e a espessura da litosfera.

As bacias oceânicas são caracterizadas por possuírem valores moderados e pouco dispersos. Os valores mais baixos são observados junto às fossas oceânicas (cerca de $0,9 \mu \mathrm{cal} \mathrm{cm}^{-2} \mathrm{~s}^{-1}$ ) apresentando, contudo, valores elevados (da ordem de $2 \mu \mathrm{cal} \mathrm{cm}^{-2} \mathrm{~s}^{-1}$ ) atrás dos arcos de ilhas (existentes, sobretudo, no Oceano Pacífico). Pelos valores aqui apresentados, é fácil verificar que a produção de calor de origem terrestre não pode ser apenas devida à desintegração de elementos radioativos. 


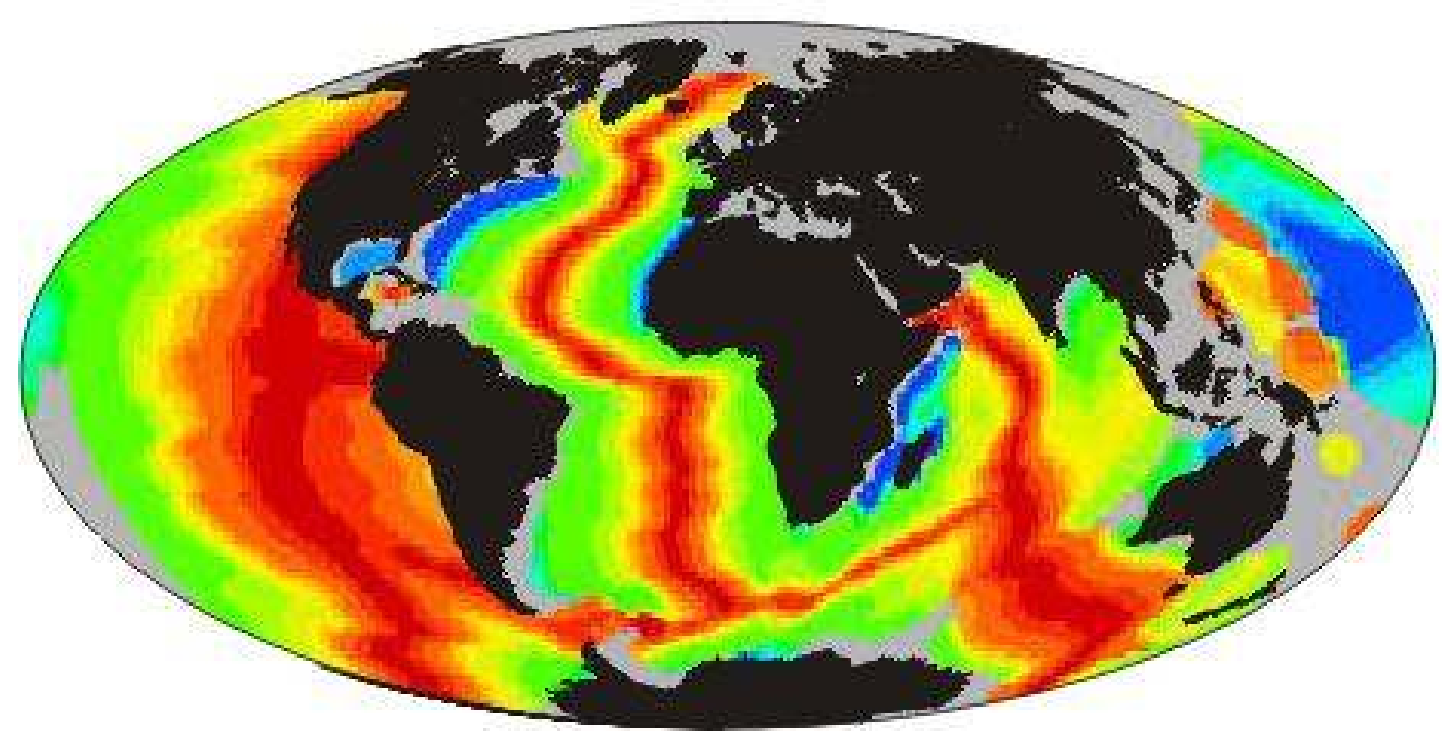

Fig. 7.3 - Fluxo de Calor nos Continentes. Em vermelho as regiões mais quentes e com vulcanismo ativo e em azul as mais frias. Observar a cadeia meso-oceânica entre Américas e África bem definida. (modificado de MULLER et alli, 1997).

\section{4 - Estrutura térmica do manto e do núcleo}

Observou-se que se assumir que a transferência de calor no manto se faz por condução, o resultado teórico obtido para a distribuição da temperatura, naquela região do planeta, não é correlacionável com os resultados obtidos através de outras observações geofísicas e petrológicas. De fato, no manto e no núcleo externo, o processo de condução não é o mecanismo principal de transferência de calor; nestas regiões profundas da Terra o processo dominante deverá ser o da convecção, sendo o calor transportado pelo material que se encontra a temperaturas mais elevadas, e que ascende das zonas profundas do planeta. A taxa de transferência é, deste modo, mais elevada que no processo de condução e, portanto, os gradientes de temperatura são pouco intensos. (MIRANDA et alli, 2005)

Quando um volume de rocha ascende rapidamente até uma determinada posição, neste processo a pressão diminui e a rocha sofre um aumento de volume e por isso arrefece, mesmo que não troque energia com o ambiente (formado pela rocha que a rodeia). Este processo termodinâmico é 
designado por adiabático. Se a temperatura final da rocha for igual à temperatura do ambiente, diz-se que o gradiente na região é adiabático.

Segundo WHITE (1970), um sistema geotermal, é uma parte da crosta terrestre que contém uma fonte de calor e as rochas e fluídos afetados por esta fonte.

A fonte de calor pode ser tanto uma intrusão ígnea localizada, como o próprio fluxo térmico regional. Sistemas geotermais que envolvem água em circulação também são chamados sistemas hidrotermais. Fontes quentes, fumarolas e outras manifestação hidrotermais evidentes são a expressão superficial de um sistema hidrotermal. Inclui-se no sistema também as partes marginais como fluxo convectivo descendente de água fria. Esta definição abrange também a área de recarga do sistema.

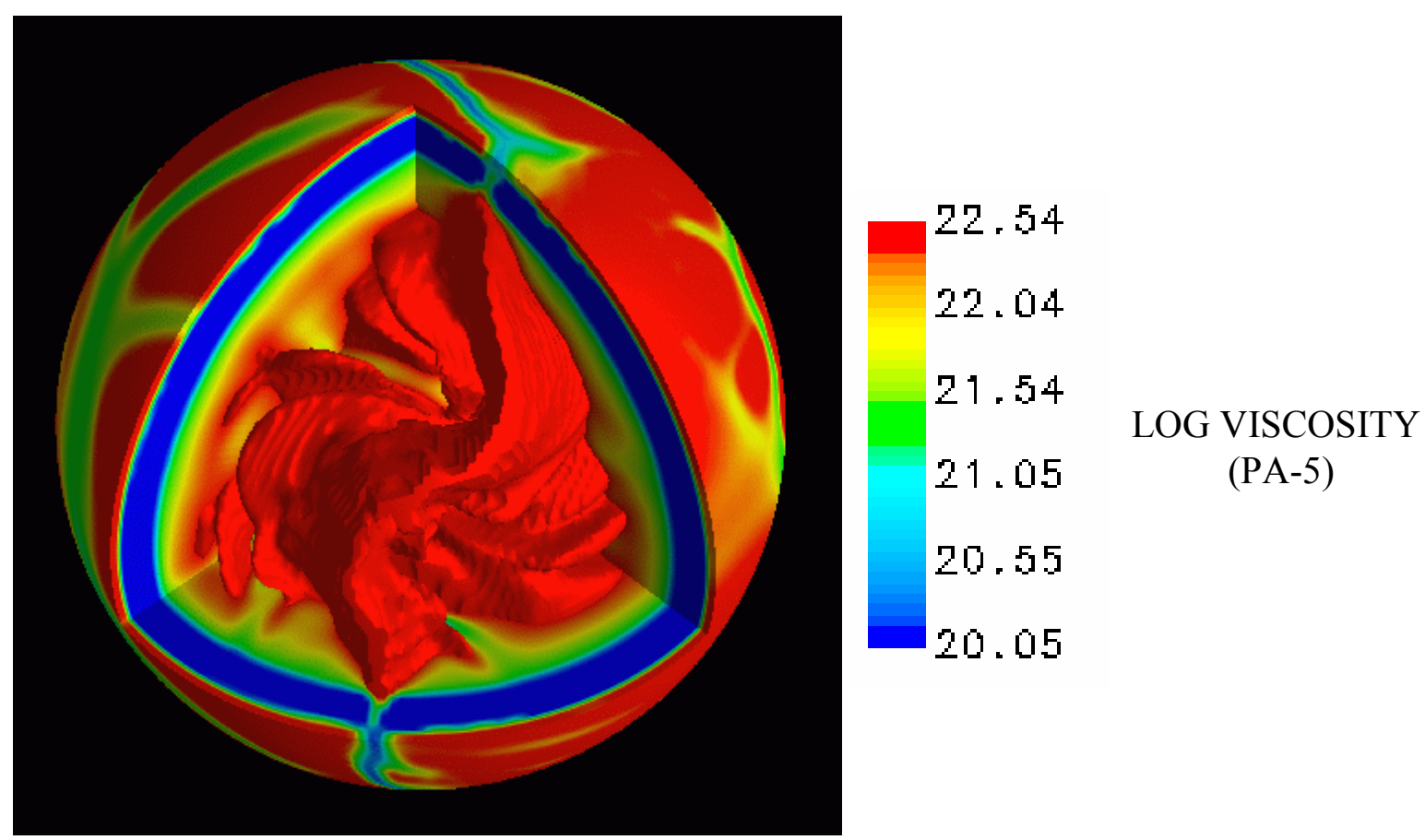

Fig. 7.4 - Modelo do núcleo 3D em vermelho, com diferenças de viscosidade. A zona da viscosidade baixa (no azul) corresponde ao manto superior da terra.

(Fonte: Nasa. http://ct.gsfc.nasa.gov/olson.finalreport/final_report.html\#geodynamo)

Os sistemas hidrotermais são classificados segundo suas temperaturas de reservatório em sistema de baixa $\left(<90^{\circ} \mathrm{C}\right)$, média (entre $90^{\circ} \mathrm{C} \mathrm{e}$ $\left.150^{\circ} \mathrm{C}\right)$ e alta temperatura $\left(>150^{\circ} \mathrm{C}\right)$ (RENNER et alli, 1975). 
Embora os isótopos radioativos existam em pequenas quantidades na crosta terrestre e sejam, ainda, menos abundantes no manto, a sua desintegração natural produz quantidades significativas de calor, como se pode verificar pela tabela abaixo:

\begin{tabular}{|c|c|c|c|}
\hline ISÓTOPO & $\begin{array}{c}\text { PERÍODO } \\
\text { ano }\end{array}$ & $\begin{array}{c}\text { PROPORÇÃO DE } \\
\text { ISÓTOPOS }\end{array}$ & $\begin{array}{c}\text { CALOR LIBERADO } \\
\text { Cal/g ano }\end{array}$ \\
\hline $\mathrm{U}^{238}$ & $4,5 \times 10^{9}$ & $99,3 \%$ & 0,73 \\
\hline $\mathrm{U}^{235}$ & $0,7 \times 10^{9}$ & $0,7 \%$ & - \\
\hline $\mathrm{Th}^{232}$ & $13,9 \times 10^{9}$ & $100 \%$ & 0,2 \\
\hline $\mathrm{K}^{40}$ & $1,3 \times 10^{9}$ & $0,01 \%$ & $27 \times 10^{-6}$ \\
\hline
\end{tabular}

Tab. 7.1 - Relação dos principais isótopos radioativos e sua contribuição em relação ao calor liberado. (MIRANDA et alli, 2005)

Os elementos mais importantes neste processo são o urânio $\left(U^{238} \mathrm{e}\right.$ $\left.\mathrm{U}^{235}\right)$, o tório $\left(\mathrm{Th}^{232}\right)$ e o potássio $\left(\mathrm{K}^{40}\right)$; pode observar-se que a contribuição do urânio e do tório é superior à do potássio. O granito é a rocha que produz mais calor devido à desintegração de materiais radioativos, pois é a que possui maior concentração destes elementos. A medição do calor gerado pelas rochas da crosta, na atualidade, pode ser usada para calcular o calor gerado no passado. Por outro lado, a concentração de elementos radiativos pode ser usada na datação das rochas (geocronologia). A taxa de decaimento de um isótopo radiativo é dada por

$$
\frac{d N}{d t}=-\lambda N
$$

Onde $\mathrm{N}$ é o número de átomos do isótopo radiativo no instante t e $\lambda$ é a constante de decaimento. A integração da equação anterior, permite conhecer o número de átomos no instante $\mathrm{t}$ :

$$
N(t)=N_{0} e^{-\lambda t}
$$

Todas as águas naturais tem um certo nível de radioatividade. Em geral as águas termo-minerais apresentam valores um pouco acima da média de outras águas não termais. Esses níveis de radiação, porém raramente ultrapassam 
os níveis máximos permitidos. Esses níveis devem ser monitorados principalmente para águas que serão usadas para fins de balneário, pelo maior grau de exposição à radiação.

Embora a taxa de geração de calor na crosta seja superior, em cerca de duas ordens de grandeza, à do manto, a taxa de produção do manto tem de ser considerada pois o volume do manto é bastante superior ao da crosta.

Nos modelos mais recentes considera-se que o calor proveniente do interior do planeta tem a sua origem no arrefecimento e na libertação de energia potencial gravítica pela absorção de $\mathrm{FeO}$ do manto, pelo núcleo. Esta reação foi produzida em laboratório a temperaturas e pressões da ordem de grandeza das existentes na fronteira núcleo-manto. À medida que o ferro fundido do núcleo extrai o FeO da perovskita do manto, o material residual menos denso, formado principalmente por óxidos de magnésio e sílica, junta-se em bolsas com dimensões suficientes para que a força de impulsão seja superior à força resistente devido à alta viscosidade do manto, e sobe em forma de plumas ou megalitos, transferindo calor para regiões mais externas do manto.

Existem certas regiões que apresentam um valor anormalmente elevado para o fluxo de calor medido à superfície. São, por exemplo, as regiões onde existem vulcões, geisers ou, fontes termais. Dentre estas zonas anômalas encontram-se campos de vapor e água quente, que foram antigamente utilizados pelos romanos nas suas termas, e que apresentam um interesse particular para a produção de energia não poluente. As Câmaras de vapor contêm água líquida sobre pressão, a uma temperatura superior a $100^{\circ} \mathrm{C}$ que, por meio de uma antiga chaminé ou de fissuras nas rochas (caso dos geisers, por exemplo), pode jorrar sob a forma de vapor. Os campos de água quente são constituídos por reservatórios a uma temperatura entre os $60^{\circ}$ e os $90^{\circ} \mathrm{C}$.

A cobertura é formada por rochas impermeáveis ou com permeabilidade muito baixa. O regime hidrológico é um fator importante na caracterização das regiões geotérmicas determinando a possibilidade da sua exploração industrial ou social, pois dele depende a recarga do reservatório.

No Brasil a legislação que regulamenta as águas termais e termominerais é o Código de Águas Minerais do Brasil (Decreto-lei $n^{\circ} 7841$, de 08/08/1945), que considera águas termais uma água cuja temperatura seja superior 
a $25^{\circ} \mathrm{C}$ ou se a temperatura da água for superior a média anual da temperatura local.

\section{5 - História do Termalismo no Brasil}

No Brasil, a legitimação do uso das águas termais acontece a partir de 1818, data associada à criação da primeira estância termal brasileira, quando em 1812, foram enviadas para a corte amostras de água termal das Caldas do Cubatão (SC), hoje Caldas da Imperatriz, para se proceder à análise. Nela foram reconhecidas propriedades terapêuticas, e as águas passaram a ser consideradas como um bem público. A situação levou dom João VI a emitir, em 1818, um decreto pelo qual ordenava a construção de um hospital termal que se deveria reger pelos estatutos do Hospital das Caldas da Rainha (Portugal).

Este é considerado o marco do início do termalismo no Brasil (SILVA, 1994), entendendo-se o termo como uma prática terapêutica desenvolvida a partir da água termal e usada no espaço de um estabelecimento balneario uma vez que já havia notícias de fontes de águas com propriedades curativas no final do século XVIII (RODRIGUEZ, 1833; GONSALVEZ et alli, 1936; MOURÃO et alli, 1992).

Foi durante o século XIX que nasceram e se desenvolveram as práticas termais em espaços institucionalizados pela medicina brasileira. Tudo começou com a descoberta das análises químicas, ainda na primeira metade do século, e com a edificação de alguns estabelecimentos termais (Caldas do Cubatão, Caxambu e Poços de Caldas) na segunda metade do mesmo século.

Nos periódicos editados pela Academia Real de Medicina no século $\mathrm{XIX}$, as primeiras notícias sobre águas minerais referiam-se às fontes termais de Goyaz e à utilização da sua água no tratamento da morféia, em 1839. Mas até esta data, poucas tinham sido as fontes termais sobre as quais se havia escrito.

Só a partir da segunda metade desse século, com 0 desenvolvimento da química e da própria medicina, surgiram notícias sobre águas minerais, sobretudo a partir das análises efetuadas, enunciando-se suas propriedades terapêuticas. Foram os médicos quem mais escreveram e publicaram 
a respeito dessa temática. Várias foram as teses de medicina produzidas sobre as águas minerais, principalmente apresentadas na Escola de Medicina do Rio de Janeiro (BENTO, 1841; CASTRO, 1841.). A primeira datava de 1841 e foi escrita por Antônio Maria de Miranda Castro. Nesta tese, o autor falava das potencialidades das águas e da necessidade de o Brasil investir nesse campo, à semelhança do que se passava na Europa, onde as águas minerais serviram de meio sanitário e fundo precioso de interesse e prosperidade, enriquecendo e civilizando estéreis vilas, citando como exemplos Caldas da Rainha, Gerês (Portugal), Spa (Bélgica) ou Forges (França).

Essa tese de medicina foi o primeiro inventário realizado sobre estações de águas brasileiras. E aí eram mencionadas as águas existentes nos estados brasileiros, classificadas segundo sua composição química. Terminava a tese pedindo ao imperador e a seu excelso avô, evocando o decreto real de 1818 (referente as Caldas do Cubatão), que tomem em consideração algumas das nossas principais águas minerais, quando não seja do ponto de vista da economia política, ao menos como um poderoso meio sanitário. (idem, ibidem).

São, no entanto, as termas de Minas Gerais aquelas sobre as quais há mais textos escritos, sobretudo Caxambu e Poços de Caldas, considerada esta última como uma estância termal que veio a assumir papel importante no quadro do termalismo brasileiro (SILVA, 1994; LIMA, 1888; MOURÃO, 1997; MARRAS, 2002.).

Os médicos exaltavam a necessidade de desenvolver a pesquisa científica sobre águas minerais, em analogia ao que se passava na Europa, contribuindo desse modo para o desenvolvimento da medicina e do país.

O conhecimento e o uso das águas minerais era assim, antes de mais nada, assumido como um fator potencial de desenvolvimento econômico. Mas, para tal, era necessário conhecer as fontes minerais existentes em solo brasileiro e desenvolver a ciência que a elas dizia respeito, designada como hidrologia médica. Eram esses os argumentos utilizados pelos autores que escreveram sobre o tema, reforçando que os médicos tinham de deter esse saber científico.de modo a poderem prescrever as águas minerais àqueles que delas necessitasse os doentes, pois as águas minerais são preconizadas como um poderoso agente da ciência médica. (SERZEDELO, 1884). 
Segundo os autores consultados, isso só aconteceu no final do século XIX. A literatura até agora levantada parece apontar para duas fases na institucionalização do termalismo brasileiro. A primeira, relativa ao século XIX, foi a fase das descobertas das águas minerais como fatos científicos, medicamentos, na perspectiva da química, da geologia e das suas propriedades terapêuticas. Era focalizada aí a necessidade de se proceder às análises químicas para legitimar o uso médico, e este não ser limitado apenas aos empregos ditos populares, evitando-se o risco de práticas classificadas como charlatanismo.

E uma vez que a água era classificada como medicamento e as termas, como uma farmácia da natureza, na cadeira de terapêutica médica foram ministrados os saberes a ela relativos, tal como propunham NETO (1917) e LOPES (1931). Foram os médicos que reivindicaram, na prática, a legitimidade do saber científico sobre as práticas termais e defenderam a necessidade de se criar uma disciplina de hidrologia médica nas faculdades de medicina como forma de afirmar o novo território médico, principalmente nas primeiras décadas do século $\mathrm{XX}$.

NETO (1917) lamentava a inexistência de cursos de hidrologia nas faculdades da medicina, situação que justificaria a pouca freqüência às estações de águas brasileiras, pois como os médicos não detinham o conhecimento, não prescreviam esse tipo de terapia. Mas as estações termais brasileiras desenvolveram-se igualmente, com a edificação de estabelecimentos vocacionados para práticas lúdicas, onde se destacavam os cassinos contíguos aos balneários.

A segunda fase iniciou-se com o século XX e correspondeu à afirmação das estações hidrominerais como lugares de cura e de turismo. MOURÃO (1992) considerava que, nas primeiras décadas do século $X X$, com a inauguração dos balneários Antônio Carlos (Poços de Caldas), Araxá e Águas de São Pedro, deu-se um inusitado interesse nos meios crenológicos nacionais, mormente entre cientistas, o que se refletiu na publicação de alguns trabalhos científicos. Mourão apresenta como exemplos àqueles realizados por médicos crenólogos de Águas de Lindóia, São Pedro e Araxá e nos trabalhos experimentais de nível técnico executados na Faculdade de Medicina de Belo Horizonte, Curitiba, Porto Alegre, Rio de Janeiro e São Paulo, ou no Departamento de Produção Mineral do Ministério da Agricultura. 
O período áureo do termalismo brasileiro terá acontecido entre 1930 e 1950 (SILVA, 1994; MOURÃO, 1992), associado às dimensões terapêutica e lúdica uma das razões do declínio foi imputada à proibição do jogo em 1946 (SILVA, ibidem). Para Mário Mourão, no ano de 1950 iniciou-se a fase do declínio do.termalismo científico, ou seja, de sua vertente médica. Isso é causado em parte a fase em que as estâncias termais passaram de centros de cura, recuperação e repouso para centros de recreação turísticos.

O desconhecimento dos recursos naturais terapêuticos gerou $O$ desinteresse e refletiu na não-receptividade do termalismo perante os médicos, particularmente entre jovens facultativos que saem das escolas ignorando esses tradicionais métodos de terapia. Este fato não permitiu que se desenvolvessem os estudos científicos, e confunde-se termalismo com turismo.

Mas Mourão afirma que, embora a parte médica tivesse entrado em declínio, o termalismo nacional, no seu enfoque físico, desenvolveram-se nos estados de Santa Catarina, Goiás e São Paulo, por meio de modernas instalações termais. 


\section{8 - Características Físico-químicas das águas termais e termo-minerais de Santa Catarina}

A classificação das águas minerais brasileiras é fundamentada no Código de Águas Minerais e tem por base a composição química e as características físicas e físico-químicas e microbiológicas, que são propriedades variáveis e inerentes a cada tipo de água do subsolo.

A qualidade química, físico-química e microbiológica das águas subterrâneas é fator básico preponderante e determinativo na sua multiplicidade de usos. É essa composição um parâmetro tão importante quanto o aspecto quantitativo e, absolutamente essencial, na caracterização e classificação de tipos distintos de águas subterrâneas, o que permite, conseqüentemente, definir ampla diversidade de campos de utilização.

Essa qualidade depende de processos e fatores endógenos e exógenos interagindo no sistema aqüífero, que contribui para o aumento da concentração de substâncias dissolvidas à proporção que a água percola os diferentes litotipos do ambiente geológico envolvido. Outros fatores também interferem como clima, composição da água de recarga, tempo de trânsito e contato água /meio físico.

Abaixo um panorama das águas termais e termo-minerais de Santa Catarina e o número de ocorrências registradas no DNPM (DNPM / - SISMINE / 2004):

- Radioativa hipertermal 1

- Radioativa termal 1

- Radioativa isotermal 1

- Fracamente radioativa termal/hipotermal 1

- Alcalino-bicarbonatadahipertermal 1

- Fluoretada radioativa hipertermal 1

- Fluoretada-sódica-cálcicaradioativa-hipertermal 1

- Fluoretada-radioativa-mesotermal 3

- Sulfatada mesotermal 1 


\begin{tabular}{|c|c|c|c|c|c|c|c|c|}
\hline \multicolumn{9}{|c|}{$\begin{array}{l}\text { PARÂMETROS FÍSICO-QUÍMICOS DAS ÁGUAS MINERAIS POTÁVEIS DE MESA DO ESTADO DE SANTA } \\
\text { CATARINA }\end{array}$} \\
\hline \multirow{2}{*}{ Tipos de Águas } & \multicolumn{4}{|c|}{ Dureza em $\mathrm{CaCO}_{3}$ em mg/litro } & \multicolumn{2}{|c|}{$\begin{array}{c}\begin{array}{c}\text { Resíduo de } \\
\text { Evaporação-mg/1 }\end{array} \\
\end{array}$} & \multirow{2}{*}{$\begin{array}{l}\text { Conduti- } \\
\text { vidade }\end{array}$} & \multirow{2}{*}{$\mathrm{PH}$} \\
\hline & \begin{tabular}{|c|} 
Branda \\
$<50$
\end{tabular} & $\begin{array}{c}\text { - Dura } \\
50 \text { a } 100\end{array}$ & $\begin{array}{c}\text { Dura } \\
100 \text { a } 200\end{array}$ & $\begin{array}{l}+ \text { Dura } \\
>200\end{array}$ & $110^{\circ} \mathrm{C}$ & $180^{\circ} \mathrm{C}$ & & \\
\hline Radioativa e Hipertemal na fonte & 27 & - & - & - & 126 & 125 & $12 \times 10^{-3}$ & 7,1 \\
\hline Fracamente Radioativa na Fonte & \begin{tabular}{|c|}
13,2 \\
$\mathrm{a}$ \\
15,63 \\
\end{tabular} & - & - & - & $\begin{array}{c}61,1 \\
\mathrm{a} \\
82 \\
\end{array}$ & $\begin{array}{c}45 \\
\mathrm{a} \\
68 \\
\end{array}$ & $\begin{array}{c}125 \times 10^{-6} \\
a \\
815 \times 10^{-7}\end{array}$ & $\begin{array}{c}5.4 \\
\mathrm{a} \\
7,0 \\
\end{array}$ \\
\hline $\begin{array}{l}\text { Fracamente Radioativa e Isotermal na } \\
\text { Fonte }\end{array}$ & 0,025 & - & - & - & 0,098 & 0,093 & $14 \times 10^{-3}$ & 6.7 \\
\hline Alcalino-bicarbonatada sódica & 20 & 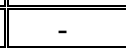 & 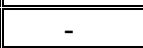 & 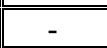 & 995 & 995 & $18 \times 10^{-4}$ & 8,5 \\
\hline Alcalino-bicarbonatada litinada & 14,03 & 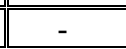 & - & 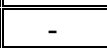 & 201,9 & 201,9 & $31 \times 10^{-5}$ & 8,8 \\
\hline $\begin{array}{l}\text { Alcalino-bicarbonatada sulfatada e } \\
\text { sulfurosa }\end{array}$ & 13,4 & - & - & - & 555,6 & 555,6 & $89 \times 10^{-5}$ & 8,68 \\
\hline Fluoretada & \begin{tabular}{|c|}
26,92 \\
$\mathrm{a}$ \\
48,09 \\
\end{tabular} & - & 103,11 & - & $\begin{array}{c}114,8 \\
\mathrm{a} \\
170 \\
\end{array}$ & $\begin{array}{c}114,8 \\
a \\
169,5\end{array}$ & $\begin{array}{c}18 \times 10^{-3} \\
a \\
165 \times 10^{-6}\end{array}$ & $\begin{array}{c}5,7 \\
a \\
7,7 \\
\end{array}$ \\
\hline Fluoretada e hipotermal na Fonte & 24,88 & - & - & - & 73 & 57 & $1 \times 10^{-3}$ & 7,8 \\
\hline Fluoretada e radioativa na Fonte & 21 & - & - & - & 93,15 & 89,15 & $104 \times 10^{-6}$ & 6,75 \\
\hline $\begin{array}{l}\text { Fluoretada e Radioativa e hipertermal na } \\
\text { Fonte }\end{array}$ & $\begin{array}{c}24,5 \\
a \\
29,07\end{array}$ & - & - & - & $\begin{array}{c}87,66 \\
\mathrm{a} \\
90,14\end{array}$ & $\mid \begin{array}{c}88,14 \\
a \\
87,66\end{array}$ & $\begin{array}{c}924 \times 10^{-7} \\
\mathrm{a} \\
954 \times 10^{-7}\end{array}$ & \begin{tabular}{|c|}
6,6 \\
$\mathrm{a}$ \\
7,2 \\
\end{tabular} \\
\hline $\begin{array}{c}\text { Fluoretada e radioativa e Mesotermal na } \\
\text { Fonte }\end{array}$ & 12,7 & - & - & - & 65 & 52 & $87 \times 10^{-4}$ & 6,09 \\
\hline
\end{tabular}

Tabela 8.1 - Determinações dos Parâmetros físico-químicos das águas minerais de Santa Catarina. Fonte: DNPM

As características físico-químicas das águas termo-minerais estão intimamente ligadas aos processos que influenciaram este quimismo e na história evolutiva das rochas onde elas ocorrem.

Com a intrusão de rochas básicas, ricas em minerais ferromagnesianos, associadas posteriormente a rochas alcalinas ricas em álcalifeldspatos, em meio a rochas graníticas encaixantes, houve grandes incrementos de minerais dissolvidos e depositados em processos termo-metamórficos.

As rochas ligadas ao corpo alcalino de Lages são rochas que foram cristalizadas na fase final de diferenciação de um magma com pouca sílica, baixa razão Si/Al e excesso dos metais alcalinos, sódio e potássio. Os três tipos principais de rochas resultantes (foiaito, tinguaíto e fonolito) mostram composição mineralógica e química muito semelhantes, sendo diferentes apenas na textura, devido às condições de resfriamento do magma original. 
A intensidade e os aspectos específicos da atividade hidrotermal em regiões vulcânicas são condicionados por uma complexa combinação de diferentes condições geológicas, geotérmicas e hidrogeológicas, que, podem mostrar grandes variações, ainda que dentro de uma área limitada (IVANOV, 1973).

Já as rochas do Corpo Alcalino de Anitápolis estão dispostas em um corpo subcircular, situado em região dominada por granitóides pré-cambrianos, na borda da Bacia do Paraná. Em superfície indica uma distribuição concêntrica das várias rochas alcalinas, agrupadas em "séries", com as dos sienitos e nefelina sienitos na periferia, e a dos ijolitos e das ultramáficas ocorrendo no interior do maciço; o conjunto é cortado por veios de carbonatito sovítico, concentrados principalmente na porção central.

Mineralogicamente é composta por feldspatos, goethita, vermiculita e/ou esmectitas e caolinita, com algum quartzo (proveniente de rochas encaixantes), fosfatos secundários e magnetita; em um nível inferior, aparece também apatita residual, anfibolito e piroxênio.

\section{1 - Características Químicas}

Nas áreas de domínio das rochas alcalinas e adjacentes, ocorreram profundas modificações do ambiente geoquímico devido aos processos hidrotermais e de meteorização das rochas.

Os processos de meteorização e intemperismo das rochas dos Complexos Alcalinos contribuiram também para uma profunda modificação do ambiente geoquímico, resultando numa variada gama de minerais secundários e supergênicos. Estes processos incluem oxidação, especialmente dos minerais ferromagnesianos (egirina e augita), com transformação em óxidos e hidróxidos de ferro; cloritização, sericitização e caulinização dos feldspatos, analcinização dos feldspatóides (nefelina), laterização e bauxitização.

Sobre os principais ambientes de formação de águas termais nas regiões de recente atividade vulcânica, IVANOV (1973) distingue quatro principais grupos: 
I. Águas termais de ambiente oxidante próximo à superfície, em áreas que recebem gases vulcânicos e fluxos termais gerados por estes gases.

II. Águas termais de ambiente redutor profundo, com condições de altas temperaturas devido à proximidades de câmaras magmáticas, com limitado influxo de gases magmáticos e termo-metamórficos.

III. Águas termais de ambiente redutor profundo sob a esfera de influência dos processos termo-metamórficos, sob condições de alta temperatura.

IV. Águas termais sob condições redutoras em profundidade, sem a influência de processos magmáticos e termo-metamórficos. Estas águas termais ocorrem, em geral, onde não há manifestação vulcânica recente; termo-metamorfismo desenvolve-se somente a profundidades muito grandes; o regime geotérmico nas formações de rochas superiores $(\mathrm{km}-2 \mathrm{~km})$ é normal ou só fracamente mais alto que o normal.

$\mathrm{Na}$ área 01 (vide anexo 03), ao norte, as águas superficiais refletem as condições do clima tropical chuvoso, com pequeno déficit hídrico, em varias microbacias, de trânsito rápido, na qual domina um solo eluvial resultante de intenso intemperismo. Nessas condições, as águas superficiais contêm apenas pequenas quantidades de sais provenientes das próprias precipitações, acrescidas de alguns componentes dissolvidos do solo, já bastante lixiviado. O processo de dissolução é comandado pelo conteúdo de $\mathrm{CO}_{2}$ dissolvido na água. Como este conteúdo é pequeno nas condições de pressão atmosférica, a capacidade de dissolução é reduzida. Em conseqüência, as águas superficiais têm baixa concentração de sais dissolvidos, dominando o bicarbonato de $\mathrm{Na}, \mathrm{Ca}$ e $\mathrm{Mg}$, em quantidades que não ultrapassam, em geral, $30 \mathrm{mg} / \mathrm{\ell}$.

A partir do momento em que as águas se infiltram, há dissolução de $\mathrm{CO}_{2}$ e de ácidos húmicos provenientes da matéria orgânica do solo, aumentando sua acidez e conseqüente capacidade de dissolução. As águas subterrâneas da zona superficial, incluindo as nascentes e fontes frias, têm composição influenciada principalmente por este aumento de $\mathrm{CO}_{2}$. São mais ácidas que as águas 
superficiais, o que permite o ataque às argilas e rochas alteradas, com incorporação de maior quantidade de $\mathrm{Ca}^{2+}, \mathrm{Mg}^{2+}$ e $\mathrm{Na}^{+}$.

São águas de ambiente oxidante, com ausência de sulfetos e caracterizadas por uma maior concentração de $\mathrm{Rn}^{222}$ e $\mathrm{CO}_{2}$ livre. Com o aumento da profundidade, ocorre uma lenta e progressiva elevação do $\mathrm{pH}$, enriquecimento em $\mathrm{HCO}^{-3}, \mathrm{Na}^{+}, \mathrm{SO}_{2}^{-4}$ e em sílica, acompanhado de uma alta concentração de fluoreto. As águas tendem para um ambiente redutor, apresentando aumento de sulfetos e decréscimo da radioatividade.

A hidrogeoquímica da sílica não está de todo esclarecida. Acreditase que a maior parte da sílica nas águas subterrâneas está como $\mathrm{SiO}_{4} \mathrm{H}_{4}$, em parte dissolvida e em parte coloidal. As águas fortemente básicas podem ter quantidades importantes de sílica iônica, que, por si, já contribuem também à alcalinidade da água. A maioria das águas naturais têm de 1 a 40 ppm de $\mathrm{SiO}_{2}$, podendo chegar a até 100 ppm em águas bicarbonatadas sódicas (CUSTÓDIO \& LLAMAS, 1976).

FOUMIER (1973), estudando a sílica em águas termais, considera que a calcedônia, antes do que o quartzo, controla o conteúdo de sílica dissolvida em aqüíferos com temperaturas abaixo de $100^{\circ} \mathrm{C}$. A forma monomérica é dominante na maioria das fontes quentes. Em águas termais neutras e alcalinas, a sílica monomérica polimeriza rapidamente para espécies cíclicas, sob resfriamento abaixo de $100^{\circ} \mathrm{C}$.

Na zona superficial, com a presença de oxigênio livre, prevalecem as condições para oxidação de sulfetos. A oxidação produz íons hidrogênio e aumenta a agressividade das águas, tornando-as ácidas, favorecendo a dissolução de carbonatos. Um considerável suprimento de oxigênio é necessário para a oxidação da pirita e, portanto, este processo ocorre só na zona superficial, e não em níveis muito abaixo da superfície freática ou onde oxigênio é deficiente.

Os processos geológicos que atuaram na formação do Complexo Alcalino de Anitápolis - intrusão alcalina, atividade vulcânica e fase hidrotermal, e processos de formação dos depósitos de Fluorita do Distrito Fluorítico de Santa Catarina - foram muito favoráveis para uma ampla disseminação de minerais contendo flúor. O fluoreto ocorre na chaminé alcalina, disseminado nas rochas de modo generalizado, e, em maiores concentrações, nos veios e fissuras preenchidos por soluções hidrotermais na área 02, no sul do estado. 
Pelo exposto, verifica-se que o enriquecimento em fluoreto das águas subterrâneas com a profundidade deve-se à dissolução da própria rocha e do material das paredes das fraturas, na qual o aumento de temperatura da água contribui para intensificar o processo de solubilização.

De acordo com a classificação de Slavianov, as águas minerais de Santa Catarina podem ser classificadas quanto aos cátions em Cálsico-sódica $(85 \%)$, sódica $(15 \%)$, e quanto a classificação aniônica em hidrocarbonatadas (53\%), hidrocarbonatada-sulfatada (23\%), sulfato-cloretada-hidrocarbonatada (16\%) e hidrocarbonatada-cloretada (8\%).

Na região da área 02 (vide anexo 03) existe um predomínio de águas fluoretadas e em menor escala as alcalino-bicarbonatadas.

Vapores superaquecidos com origem profunda tem temperatura superior á necessária para produzir vapores a pressão existente em profundidade. Movimentos tectônicos de grande profundidade poderiam fazer circular águas "juvenis" e caráter ácido, com cálcio, cloro, sódio, potássio, (que ocorrem nas fontes termais de região) e flúor, que só ocorrem em filões, sendo que em quase todas as fontes existem frações desse elemento.

A mineralização secundária ocorre em fraturas abertas por movimentos tectônicos tensionais e renovação de antigas estruturas; a exceção da pirita, havendo indícios de movimentação durante o processo de preenchimento.

O controle estrutural dos filões de fluorita é representado por fraturas com direções $\mathrm{N} 40^{\circ}-60^{\circ} \mathrm{E}$, associadas as grandes falhas com direção predominante $\mathrm{N}-\mathrm{S}$, que afetam as rochas sedimentares do Subgrupo Tubarão.

Pode-se tirar algumas conclusões a respeito da gênese destas águas comparando-as com as ocorrências de fluorita no sul do Estado:

Há uma constância das características físico-químicas da água das fontes a mais de 50 anos, pois se pode comparar com as determinações realizadas por Andrade Junior em 1928.

* Ocorre grande semelhança tanto no modo de ocorrência, como nas características físico-químicas nas fontes da região. 
* A ocorrência das surgências de água termal na área, associadas a estrutura tipo falhas, preenchidas por quartzo, tendo inclusive sido descrita a ocorrência de fluorita associada, a semelhança das fontes termais do norte do Estado.

Ocorre associação das fontes com tectônica nordeste, a mais comum nas ocorrências de fluorita e de fontes termais na região do sul do Estado.

\subsection{1 - Radioatividade}

Acredita-se que a radiatividade da água mineral de Termas do Gravatal (24,8 UM), bem como das demais águas radioativas da Província Termoradioativa do Sudeste Catarinense, provenham em parte da incorporação do gás radônio $\left({ }^{86} \mathrm{RN}^{238}\right)$, mais precisamente do metal rádio $\left({ }^{88} \mathrm{RN}^{226}\right)$, contido nos minerais acessórios (esfeno, zircão, monazita, apatita, ilmenita, entre outros) dos granitos e principalmente dos granitos alcalinos do embasamento. Salienta-se que a meia vida do radônio é de apenas 3,8229 dias e que após este período ele se transforma em um semi-metal, o polônio $\left({ }^{84} \mathrm{RN}^{218}\right)$ (Fonte: DNPM - Relatório final de Pesquisa)

\section{2 - Características Físicas}

\subsection{1 - Temperatura}

Mais de $20 \%$ das águas minerais brasileiras são classificadas em função da temperatura, em hipotermais, isotermais, mesotermais e hipertermais. As hipotermais são nitidamente as mais dominantes.

No Estado de Santa Catarina foram identificadas pelo DNPM 18 tipos de águas minerais, uma grande parcela delas hipotermais, isotermais, mesotermais e hipertermais.

Segundo IVANOV (op. cit.), na presença de falhas tectônicas e fraturamentos profundos e abertos, há condições para infiltração profunda de águas meteóricas e para a formação de águas termais nitrogenadas, em meio fissurado, 
cuja composição não é relacionada a fenômenos magmáticos e termometamórficos, mas é exclusivamente determinada por processos de lixiviação das rochas (principalmente vulcânicas e vulcano-sedimentares).

As águas subterrâneas da zona de circulação superficial (nascentes e fontes frias) têm temperaturas geralmente inferiores a $24^{\circ} \mathrm{C}$ e, embora não sejam feitas medições periódicas, algumas fontes devem apresentar variações sazonais por influência do calor solar, conforme se infere de medidas existentes feitas em diferentes épocas.

O urânio, tório e rádio estão presentes nas águas subterrâneas em quantidades muito pequenas. O urânio é ligeiramente solúvel. Em meio redutor, precipita-se com facilidade. Águas muito ácidas podem ter quantidades importantes de urânio, como também as águas alcalinas bicarbonatadas, na forma de complexos solúveis. O tório é muito menos solúvel.

As águas minerais Mesotermais e oligometálicas da região sul, seriam manifestações finais do processo hidrotermal, já que em sua maioria estão situados próximos aos veios de fluorita. São águas bicarbonatadas, cloretadas e sulfatadas. A temperatura média nestas fontes varia de $35^{\circ}-36^{\circ} \mathrm{C}$ (São Pedro, Gravatal e Guarda).

Segundo pesquisas realizadas pelo Observatório Nacional - ON, em 2004, em seu "Estudos Geotérmicos no Estado de Santa Catarina", lança luz sobre alguns dados do geotermalismo em Santa Catarina. Como parte do trabalho foram coletadas amostras que foram medidas em laboratório para a obtenção de parâmetros como condutividade térmica, calor específico e difusibilidade térmica, além de coleta de dados diretos como temperatura das fontes e poços tubulares, que serviram para atualizar as medições mais antigas, feitas com equipamentos menos precisos.

A tabela a seguir mostra valores encontrados para alguns desses parâmetros e que foram utilizados posteriormente para a confecção de um mapa de fluxo geotérmico para o Estado de Santa Catarina. 


\begin{tabular}{|c|c|c|c|c|c|}
\hline \multirow{2}{*}{ Amostra } & \multirow{2}{*}{ Litologia } & \multirow{2}{*}{ Local da amostra } & $\begin{array}{c}\text { Condutividad } \\
\text { e Térmica } \\
\end{array}$ & $\begin{array}{c}\text { Calor } \\
\text { Específico }\end{array}$ & $\begin{array}{c}\text { Difusividade } \\
\text { Térmica }\end{array}$ \\
\hline & & & $(\mathrm{W} / \mathrm{m} \mathrm{K})$ & $\mathrm{J} /(\mathbf{k g ~ K})$ & $\mathrm{m}^{2} / \mathrm{s}$ \\
\hline AR-Dd & Granito Alterado & Ilha do Arvoredo & 2,01 & - & - \\
\hline E-Z & Granito Milonítico & Ilha S. Catarina & 2,50 & $2,04 \mathrm{E}+06$ & $1,23 \mathrm{E}-06$ \\
\hline $\mathrm{E}-\mathrm{Z}$ & Granito Milonítico & Ilha S. Catarina & 2,49 & $2,12 \mathrm{E}+06$ & $1,17 \mathrm{E}-06$ \\
\hline CB-318 & Riolito Pórfiro & $\begin{array}{l}\text { S. Plut. Vulc } \\
\text { Cambirela } \\
\end{array}$ & 2,64 & $2,08 \mathrm{E}+06$ & $1,27 \mathrm{E}-06$ \\
\hline CB-318 & Riolito Pórfiro & $\begin{array}{l}\text { S. Plut. Vulc } \\
\text { Cambirela }\end{array}$ & 2,68 & $2,07 \mathrm{E}+06$ & 1,29E-06 \\
\hline CB-413 & Ignimbito Riolítico & $\begin{array}{l}\text { S. Plut. Vulc } \\
\text { Cambirela }\end{array}$ & 0,10 & - & - \\
\hline CB-413 & Ignimbito Riolítico & $\begin{array}{l}\text { S. Plut. Vulc } \\
\text { Cambirela }\end{array}$ & 2,90 & $2,03 \mathrm{E}+06$ & $1,43 \mathrm{E}-06$ \\
\hline CB-413 & Ignimbito Riolítico & $\begin{array}{l}\text { S. Plut. Vulc } \\
\text { Cambirela }\end{array}$ & 2,75 & $1,98 \mathrm{E}+06$ & 1,39E-06 \\
\hline CB-401 & Granito Porfíritico & $\begin{array}{l}\text { S. Plut. Vulc } \\
\text { Cambirela }\end{array}$ & 3,89 & $2,24 \mathrm{E}+06$ & $1,74 \mathrm{E}-06$ \\
\hline CB-402 & Granito Porfíritico & $\begin{array}{l}\text { S. Plut. Vulc } \\
\text { Cambirela }\end{array}$ & 3,68 & $2,20 \mathrm{E}+06$ & $1,67 \mathrm{E}-06$ \\
\hline PS-13-LL-8 & Diabásio & Pantano do Sul & 2,74 & $2,11 \mathrm{E}+06$ & $1,30 \mathrm{E}-06$ \\
\hline PS-13-LL-8 & Diabásio & Pantano do Sul & 2,57 & $2,05 \mathrm{E}+06$ & $1,26 \mathrm{E}-06$ \\
\hline CB-430 & Riolito & $\begin{array}{l}\text { S. Plut. Vulc } \\
\text { Cambirela }\end{array}$ & 3,46 & $2,12 \mathrm{E}+06$ & 1,63E-06 \\
\hline CB-430 & Riolito & $\begin{array}{l}\text { S. Plut. Vulc } \\
\text { Cambirela }\end{array}$ & 3,17 & $2,05 \mathrm{E}+06$ & $1,55 \mathrm{E}-06$ \\
\hline CB-344 & Rocha alterada & $\begin{array}{l}\text { S. Plut. Vulc } \\
\text { Cambirela }\end{array}$ & 2,49 & $2,02 \mathrm{E}+06$ & $1,24 \mathrm{E}-06$ \\
\hline CB-344 & Rocha alterada & $\begin{array}{l}\text { S. Plut. Vulc } \\
\text { Cambirela }\end{array}$ & 2,44 & $2,01 \mathrm{E}+06$ & $1,22 \mathrm{E}-06$ \\
\hline CB-118-A & $\begin{array}{c}\text { Riolito c/vidro } \\
\text { vulcanico }\end{array}$ & $\begin{array}{l}\text { S. Plut. Vulc } \\
\text { Cambirela }\end{array}$ & 3,04 & $2,08 \mathrm{E}+06$ & $1,47 \mathrm{E}-06$ \\
\hline CB-118-A & $\begin{array}{l}\text { Riolito c/vidro } \\
\text { vulcanico }\end{array}$ & $\begin{array}{l}\text { S. Plut. Vulc } \\
\text { Cambirela }\end{array}$ & 2,92 & $2,05 \mathrm{E}+06$ & $1,43 \mathrm{E}-06$ \\
\hline $\begin{array}{l}\text { TOTAL } \\
\text { GERAL }\end{array}$ & - & - & 2,85 & $2,08 E+06$ & 1,39E-06 \\
\hline
\end{tabular}

Tabela 8.2 - Resultados das medidas das propriedades termofísicas das amostras. (Fonte: CARDOSO et alli, 2004) 


\begin{tabular}{|c|c|c|c|}
\hline $\begin{array}{c}\text { Tipo } \\
\text { Litológico }\end{array}$ & $\begin{array}{c}\text { Condutividade } \\
\text { Térmica (W/m K) }\end{array}$ & $\begin{array}{c}\text { Calor } \\
\text { Específico }(\mathrm{J} / \mathrm{kg} \\
\text { o } \\
\mathrm{C}) \\
\end{array}$ & $\begin{array}{c}\text { Difusividade } \\
\text { Térmica } \\
2 \\
\left(\mathrm{~m}^{2} / \mathrm{s}\right) \\
\end{array}$ \\
\hline Diabásio & 2,66 & $2,08 \mathrm{E}+06$ & $1,28 \mathrm{E}-06$ \\
\hline Granito Milonítico & 2,50 & $2,08 \mathrm{E}+06$ & $1,20 \mathrm{E}-06$ \\
\hline Granito Porfíritico & 3,79 & $2,22 \mathrm{E}+06$ & $1,71 \mathrm{E}-06$ \\
\hline Granito Alterado & 2,01 & - & - \\
\hline Ignimbito Riolítico & 2,83 & $2,01 \mathrm{E}+06$ & $1,41 \mathrm{E}-06$ \\
\hline Riolito & 3,32 & $2,09 \mathrm{E}+06$ & $1,59 \mathrm{E}-06$ \\
\hline $\begin{array}{c}\text { Riolito c/vidro } \\
\text { vulcanico }\end{array}$ & 2,98 & $2,07 \mathrm{E}+06$ & $1,45 \mathrm{E}-06$ \\
\hline Riolito Pórfiro & 2,66 & $2,08 \mathrm{E}+06$ & $1,28 \mathrm{E}-06$ \\
\hline Rocha Alterada & 2,47 & $2,02 \mathrm{E}+06$ & $1,23 \mathrm{E}-06$ \\
\hline
\end{tabular}

Tabela 8.3 - Valores médios das Propriedades termofísicas por tipo litológico. (Fonte: Fonte: CARDOSO et alli, 2004)

CARDOSO et alli (2004), mostra que os cálculos preliminares indicam profundidades de cerca de 700 a 1200 metros para circulação de fluidos nos sistemas hidrotermais hospedados na suíte intrusiva Pedras Grandes. Este valor foi utilizado na determinação de gradientes térmicos, conforme tabela abaixo:

\begin{tabular}{|c|c|c||c|c|}
\hline Local & Local & Longitude Decimal & Latitude Decimal & $\begin{array}{c}\text { Fluxo } \\
\left(\mathbf{m W} / \mathbf{m} \mathbf{~}^{2}\right.\end{array}$ \\
\hline \hline Gravatal & Fonte1 & 49,0500 & 28,3333 & 102 \\
\hline \hline Rio do Pouso & Fonte1 & 49,1333 & 28,4167 & 96 \\
\hline Guarda & Fonte1 & 49,1333 & 28,4333 & 78 \\
\hline \hline Águas Mornas & Fonte1 & 48,8333 & 27,7167 & 96 \\
\hline \hline Águas Mornas & Fonte2 & 48,8333 & 27,7167 & 96 \\
\hline \hline Águas Mornas & Fonte3 & 48,8333 & 27,7167 & 114 \\
\hline Caldas Imperatriz & Fonte1 & 48,6833 & 27,6833 & 114 \\
\hline \hline Caldas Imperatriz & Fonte1 & 48,6833 & 27,6833 & 114 \\
\hline
\end{tabular}

Tabela 8.4 - Fluxo geotérmico nas áreas de fontes termais na região leste. (Fonte: Fonte: CARDOSO et alli, 2004) 
Ao encontrar valores anômalos de fluxo térmico na Borda Leste em relação a região Oeste de Santa Catarina, ficou caracterizada que a região da borda Leste possui um campo geotérmico anômalo em relação à região oeste, com valores em média cerca de $50 \%$ inferiores a borda Leste. (CARDOSO et alli 2004)

Com base nos dados obtidos em vários levantamentos pelo IPT/ON, foi elaborado de um novo mapa de fluxo geotérmico do Estado de Santa Catarina, apresentado na figura abaixo.

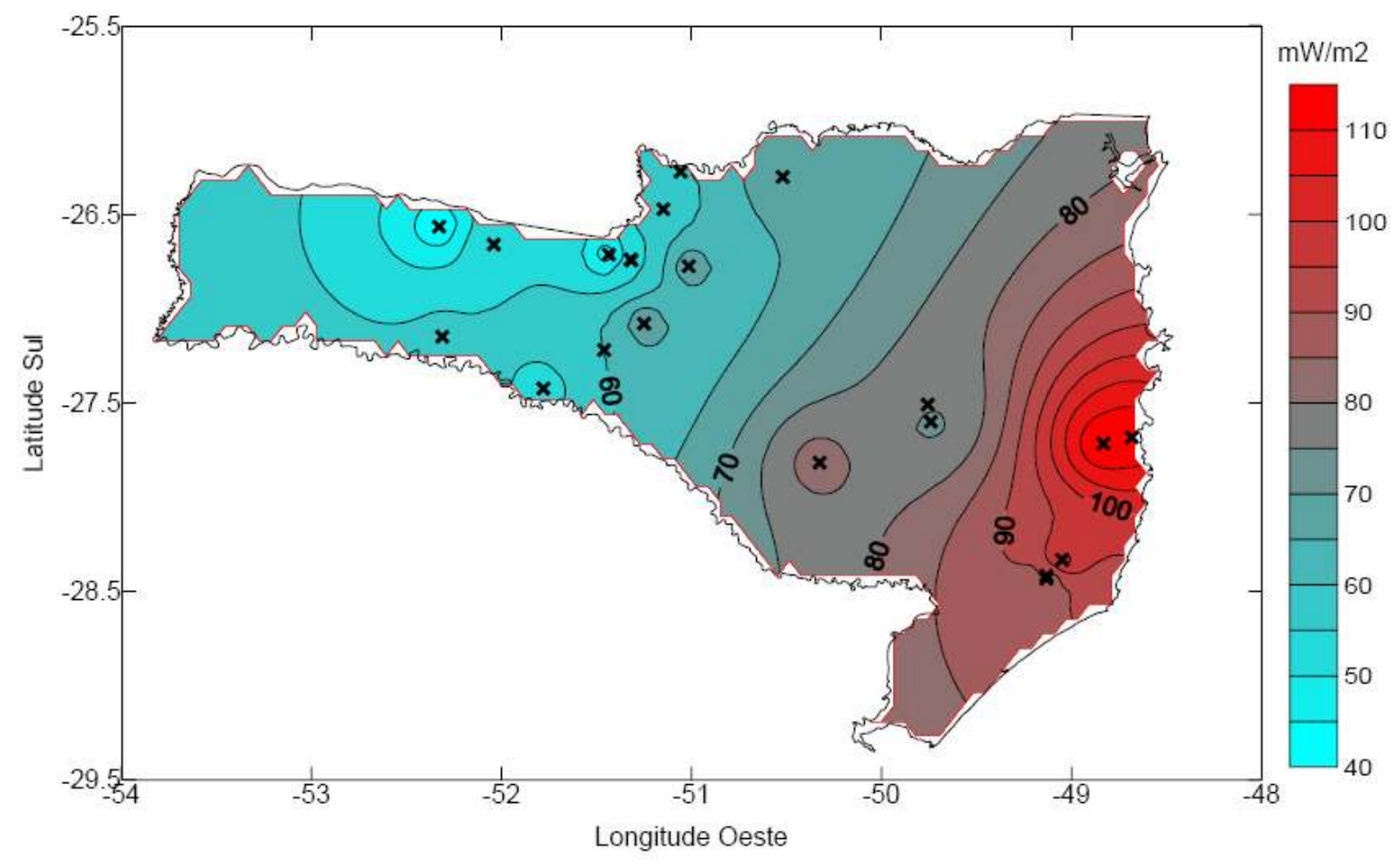

Figura 8.1 - Mapa de Fluxo geotérmico do Estado de Santa Catarina. (fonte: Fonte: CARDOSO et alli, 2004)

A presença de um número significativo de fontes termais distribuídos numa área ampla (dimensões de centenas de quilômetros) e a identificação de uma anomalia positiva no fluxo geotérmico regional aponta para a existência de um sistema hidrotermal de baixa entalpia na parte leste do estado de Santa Catarina. O comportamento deste sistema hidrotermal pode ser mais bem estudado através de modelagem das suas características físico-químicas (CARDOSO, op.cit).

A ausência de dados de perfilagem térmica de poços profundos não permitiu seu uso direto dos dados coletados para o ajuste do modelo. Contudo, os 
dados geotérmicos e geológicos regionais apontam para domínios prováveis do modelo compatível com os dados observados. Exame deste domínio indica que a profundidade máxima de circulação na área geotermal está na faixa de 700 a 1200 metros.

As vazões encontradas estão na faixa de 10 a $50 \mathrm{~m}^{3} / \mathrm{h}$ o que implica que a permeabilidade das fraturas em profundidade é significativa. Conclui-se, portanto que o processo tectonotermal que gerou a anomalia no fluxo geotérmico deve ter induzido alterações recentes na permeabilidade das fraturas. (CARDOSO, op. cit.). 


\section{9 - TERMALISMO EM SANTA CATARINA}

\section{1 - Introdução}

O estado de Santa Catarina apresenta três principais regiões geotérmicas em exploração, sendo que destas três regiões, uma é explorada exclusivamente na forma de captações artificiais e duas na forma de ocorrências naturais e captações artificiais.

A primeira Região situa-se na porção centro-sudoeste do Estado de Santa Catarina (sendo os principais municípios os de Águas de Chapecó, Itá e Piratuba) e é caracterizada por ocorrências na forma de poços tubulares profundos, em média superiores a $600 \mathrm{~m}$ de profundidade com temperatura média da água de $38^{\circ} \mathrm{C}$. Como este trabalho visa analisar a gênese das águas termo-minerais em ocorrências naturais surgêntes (ou captações em poços tubulares ou caixas de captação, desde que próximos às ocorrências naturais) em todo o estado de Santa Catarina, optou-se por excluir esta primeira região, por não apresentar fontes que se enquadrassem nestas características.

A segunda região localiza-se na porção centro-oriental do estado, próximo a cidade de Florianópolis, capital do Estado de Santa Catarina, onde ocorrem na forma de surgências naturais e captações artificiais (nos municípios de Santo Amaro da Imperatriz, Águas Mornas, Palhoça, São Bonifácio) com temperaturas que variam de $33^{\circ} \mathrm{C}$ a $45^{\circ} \mathrm{C}$.

A terceira região localiza-se no sudeste do estado (municípios de Tubarão, Gravatal, Pedras Grandes, Imaruí, Armazém e Santa Rosa de Lima) e caracteriza-se por ocorrências na forma de surgências naturais e captações artificiais, cujas águas atingem temperaturas de cerca de $38^{\circ} \mathrm{C}$.

No extremo sul do Estado, no Município de São João do Sul, ocorre a única fonte termo-mineral salgada do Brasil, esta ocorrência por ser pequena e por ser captada apenas por poço tubular profundo, não será adicionada neste trabalho. Este poço de São João do Sul é proveniente de uma sondagem feita pela CPRM em busca de jazimentos de carvão. As regiões estudadas neste trabalho são as da região central e sul da borda Leste do Estado de Santa Catarina. 


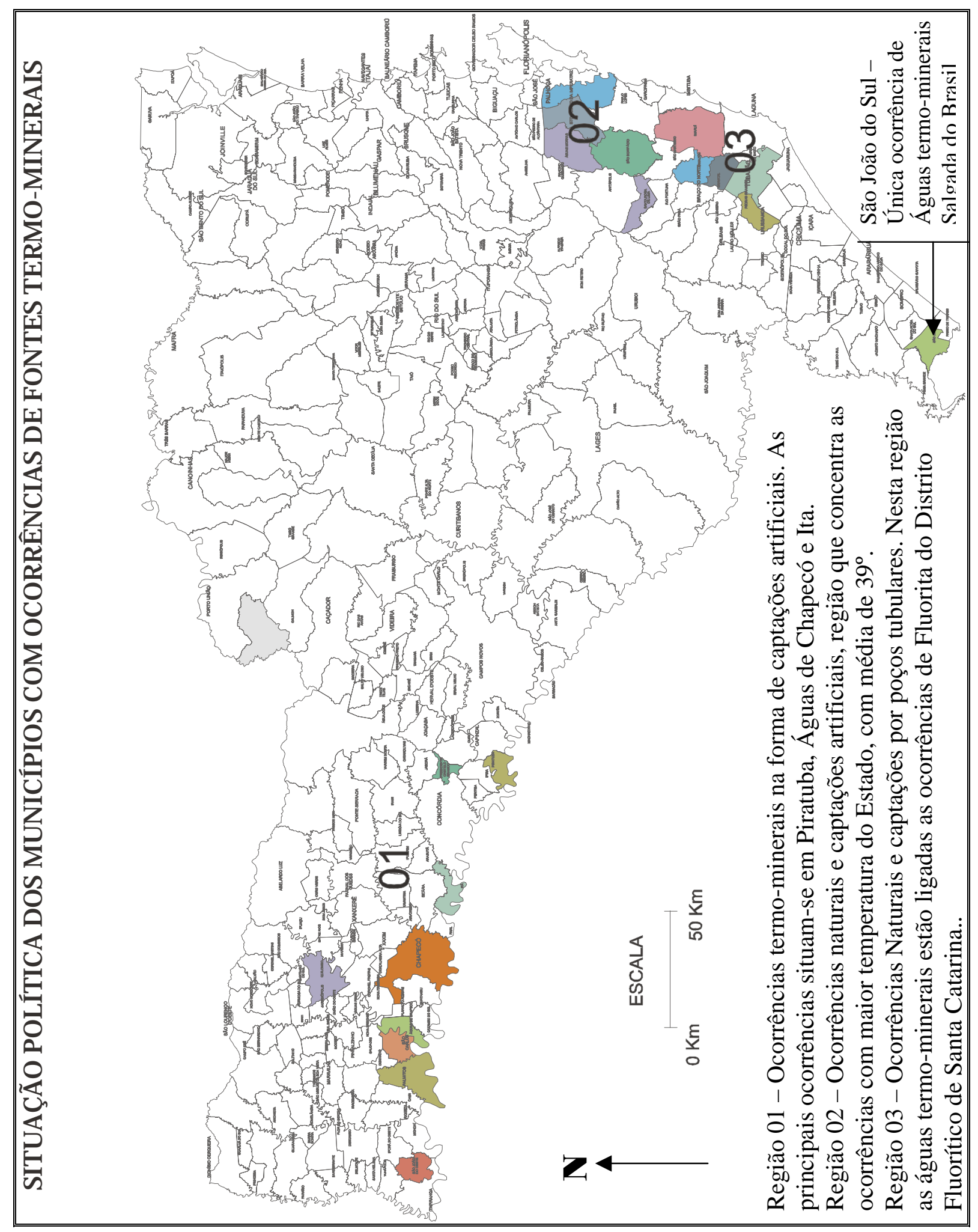

Fig. 9.1 - mapa de Santa Catarina com os municípios com ocorrências termais e termo-minerais conhecidas. Os municípios com ocorrência estão preenchidos em cores variadas 


\section{2 - Histórico de Exploração de Águas Termais no Estado de Santa Catarina}

O Estado de Santa Catarina apresenta um histórico de pesquisa e exploração dos recursos hidrogeológicos muito recente. Apesar de historicamente ter sido o primeiro estado do Brasil a declarar uma estância termal de utilidade pública, estas nunca foram devidamente estudadas.

Os primeiros registros sobre a existência de águas termais e termominerais no estado de Santa Catarina foram feitas por um viajante Inglês chamado Loccok, (o qual não se tem muita informação), em 1809, às margem do Rio Cubatão, no Município de Santo Amaro da Imperatriz, onde revelou ocorrências naturais de águas termais que foram associadas com as águas termais do Balneário Inglês de Harrogate. As águas catarinenses, porém, apresentam uma temperatura maior que sua correlata inglesa.
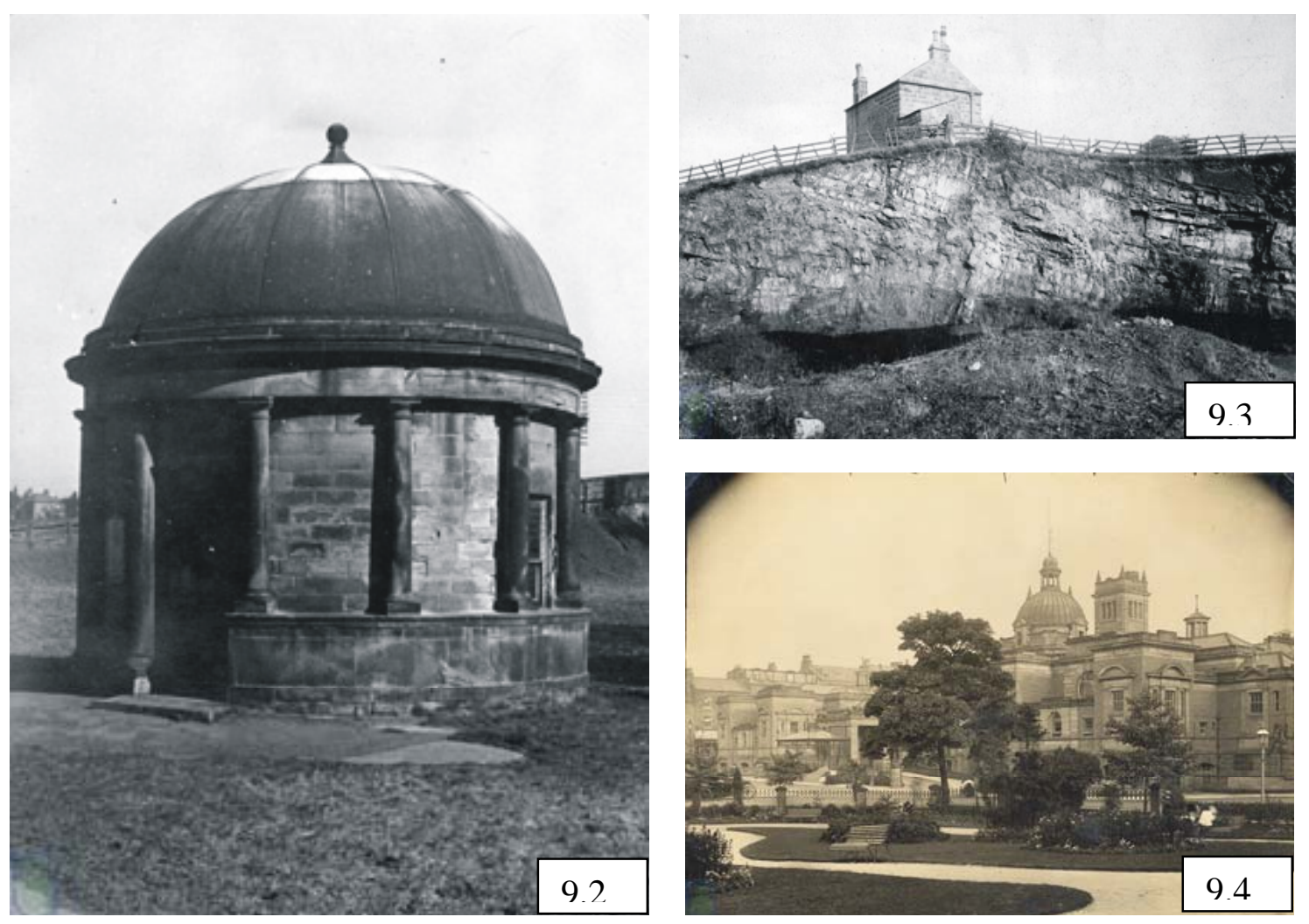

Fig. 9.2, 9.3 e 9.4 - Em sentido Horário da foto maior, vistas da Estâncias de Horrogate e abaixo o "The Royal Bath Hospital", balneário para tratamento crenoterápico de Horrogate. (Fonte: http://www2.northyorks.gov.uk) 
Em 1812 foram levadas para a Corte Imperial algumas garrafas desta água e em 1813, o Governo Imperial tomou conhecimento de que habitantes das circunvizinhanças vinham em busca dessas águas para alívio de suas doenças. Alguns, inclusive, construíram choças para permanecer no local por mais tempo. (SANTOS, 1994).

Os itens seguintes tratam da evolução individual de alguns dos principais municípios e de suas relações com a evolução da exploração das águas termo-minerais.

\section{3 - Santo Amaro da Imperatriz}

Em 1795, foi dado o início ao processo de povoamento do atual Município de Santo Amaro da Imperatriz, com a chegada dos primeiros desbravadores no Arraial do Cubatão. A localidade começou a ser povoada por famílias de origem açoriana vindas de São José e Enseada do Brito, em um período em que o Arraial era coberto por matas virgens e abrigava índios. Posteriormente, famílias de origem alemã vindas da Colônia de Teresópolis iniciaram atividades na lavoura e a construção de engenhos de açúcar e farinha de mandioca.

O antigo arraial, então conhecido por Sant'Ana do Cubatão, fazia parte da Paróquia de São José. Limitava-se ao sul, com a paróquia de Nossa Senhora do Rosário da Enseada de Brito, pelo rio Braço de São João; a leste e norte, com a de São José pelo morro dos Quadros (ou Baltazar) e morro da Taquara e com a Colônia de Teresópolis, pelo morro da Vargem grande (ou Tabuleiro) (DUTRA, 1992).

Segundo MARTINS (2001), em sua obra "Tabuleiro das Águas", as primeiras expedições em busca das fontes termais foram comandadas pelo capitão João Marcos de Andrade. Porém a ordem era "apenas observar, analisar e descrever o que fosse necessário". Informado do fato, o Governo resolveu enviar para aquele ponto um destacamento de milicianos para tomar conta da fonte e encarregar-se de sua conservação. Quando os indígenas que habitavam a região se sentiram privados da abundante caça ali existente, atacaram os milicianos, em 30 de outubro de 1814, exterminando o destacamento e incendiando o abrigo que 
Ihes servia de quartel. Em homenagem aos soldados mortos nesse massacre foi erigida uma placa (foto 9.5).

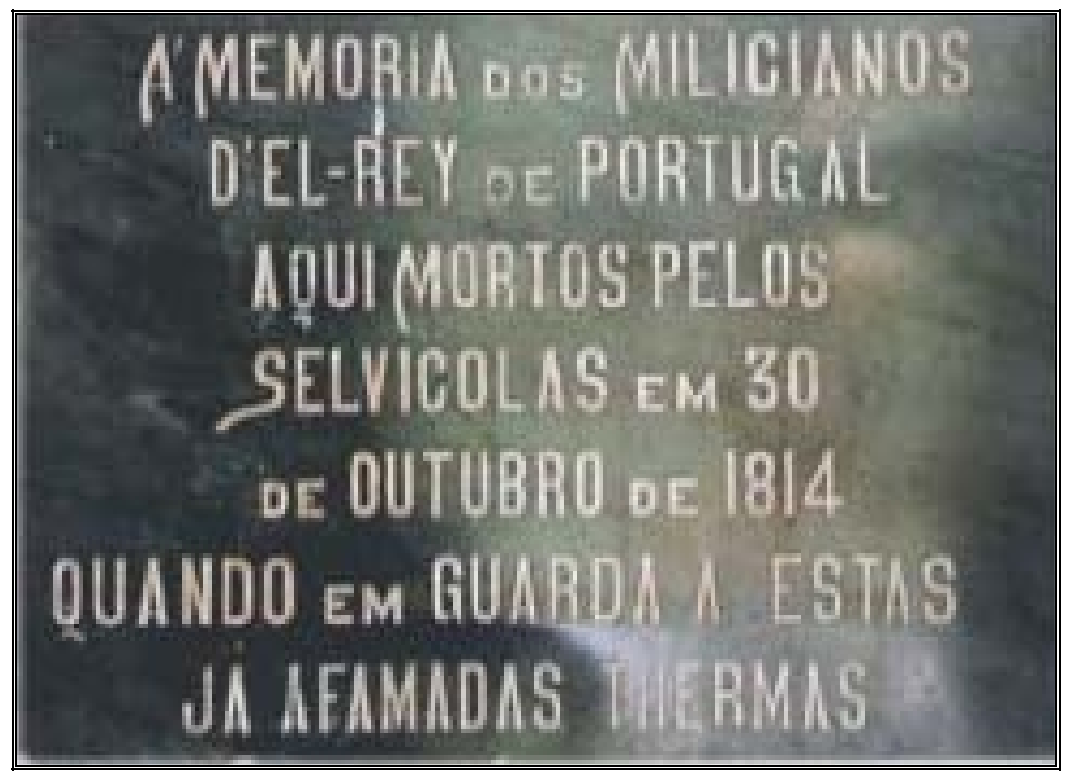

Fig. 9.5 - Homenagem ao dia do massacre da Guarda Imperial.

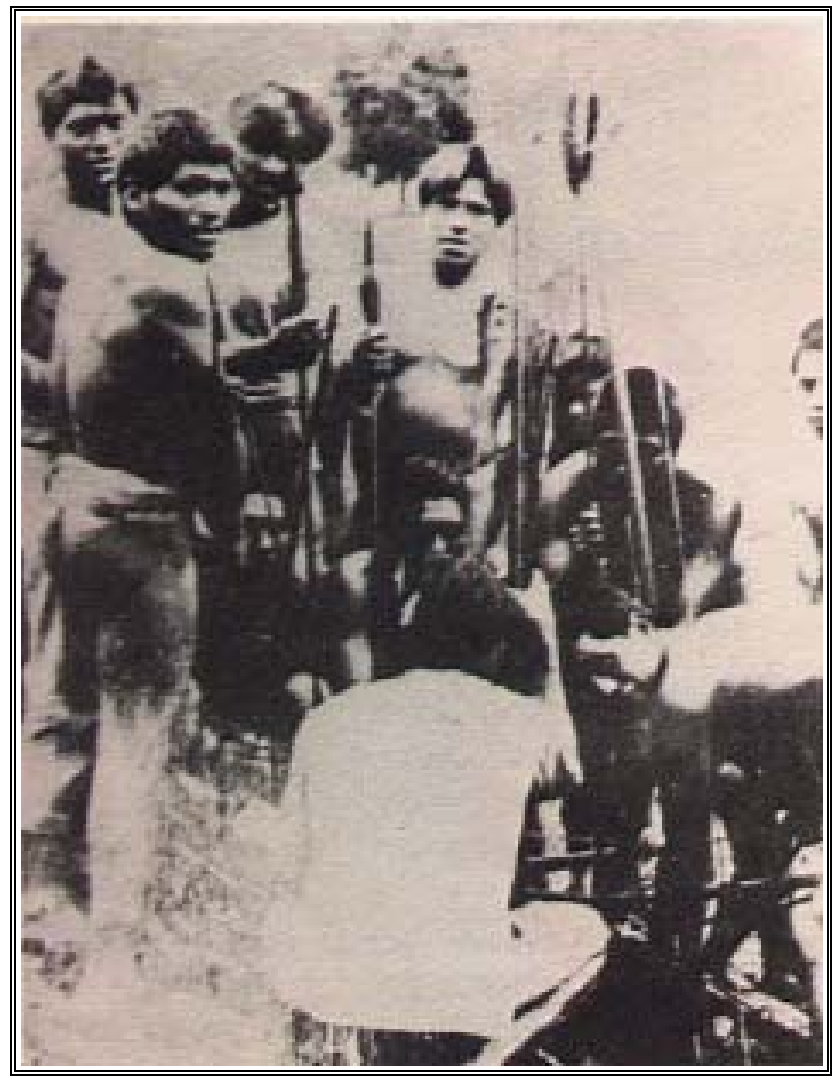

Fig. 9.6 - índios botocudos do Vale do Itajaí in "Índios e Brancos no Sul do Brasil" SANTOS (1973). 
Somente em 1818 as fontes foram retomadas dos índios por ordem do governador João Vieira Tovar de Albuquerque, que fez o primeiro pronunciamento oficial publicado a 02 de fevereiro de 1818, do qual destaca-se o seguinte trecho:

"Temos entre nós um manancial de beneficência pública, e havemos de privar o público, a Nação e, enfim, a humanidade deste presente que nos confiou a natureza? Ah! Não. Cidadãos generosos, o rico tesouro de águas termais que temos em frente a nossa vista, mas coberto por obstáculos, deve franquear-se a todas as gerações de um modo fácil e digno de vós. A posteridade gozando de seu benefício deve apontar com o dedo e exclamar: "Isto se deve aos Catarinenses e honra aos benfeitores da humanidade. "

Em seguida, ao apelo do governador catarinense, o Rei João VI fez baixar um decreto no dia 18 de março de 1818, determinando a construção de um hospital, o que é considerado a primeira lei de criação de uma Estância Termal no Brasil. A partir destes atos oficiais, foi determinada a construção provisória de alguns leitos, destinados a abrigar o grande número de enfermos que utilizavam as já conceituadas águas. Decorridos alguns anos, em 1835, através da Lei provincial $n^{\circ} 16$ do dia 12 de maio, foi atribuída a execução do empreendimento, criado por Decreto Imperial, à Câmara Municipal de São José.

Segundo MARTINS (2001), "O decreto real de 8 de março de 1818 determinando a construção de um hospital em Caldas do Cubatão não foi muito bem recebido por Manoel de Miranda Bittencourt, dono das terras onde foram achadas." referindo-se às fontes.

Entre os anos de 1837 a 1839 foi construída uma Capela, no morro da Tapera (também conhecido como Morro do Euzébio), para onde foi trazida a imagem da padroeira do Cubatão - Sant'Ana - por religiosos colonizadores, provavelmente oriundos da Galícia, uma região da Espanha, dando origem ao segundo nome da localidade: Sant'Ana do Cubatão.

Face à impossibilidade da Câmara concretizar a obra da construção do Hospital, a Assembléia provincial, pela Lei $n^{0}$ 164, de 18 de março de 1842, 
encarregou o presidente da Província de executá-la com recursos do Governo e outros provenientes de doações e loterias. Parte dos recursos para a construção do hospital foram conseguidos através de diversas loterias autorizadas especialmente para este fim. Em 1844, entre outros recursos obtidos de doações, foram recebidos do Governo Imperial $2.000 \$ 000$ réis e de S.M. a Imperatriz Tereza Cristina que doou $400 \$ 000$ réis, oportunidade em que ela aceitou o título de Protetora do Hospital Caldas, permitindo que estas se denominassem Caldas da Imperatriz.

Em outubro de 1845, nos dias de 29 a 30, suas majestades D. Pedro d'Alcântara - D.Pedro II e sua esposa a Imperatriz Tereza Cristina estavam presentes na festa que ocorreu em Sant'Ana. Foi a maior festa que a região tinha feito até então, com procissão, fogos, visitas, beija-mão, cerimônia na Igreja e banquetes para agradar os visitantes e sua comitiva. O nome Caldas da Imperatriz, porém, não surgiu com esta visita.

A denominação foi adotada quando D. Tereza Cristina assumiu o título de protetora do Hospital de Caldas do Cubatão, no ano de 1844, e fez doações para a continuidade das obras. Com o aumento da população local, a Capela de Sant'Ana tornou-se insuficiente, e o povo passou a procurar um novo local para a construção (iniciada em 1850) de uma nova Igreja Matriz. Tal construção teve a iniciativa do padre Macário, um grande colaborador que fez com que fosse criada a freguesia e incentivou o surgimento da Festa do Divino. Uma imagem de Santo Amaro surgiu na localidade, sem que alguém tivesse conhecimento da sua origem, ou seja, soubesse quem a encomendara ou onde fora feita. Essa imagem foi guardada durante meses pelo padre, que tinha o objetivo de entregar a quem a reclamasse. Como não houve reclamações, a imagem foi entronizada com a conclusão da nova Igreja, e o Arraial passou a denominar-se Santo Amaro do Cubatão.

Entre três projetos que foram enviados ao presidente da província foi escolhido o do Tenente-Coronel de Engenheiros Patrício Antônio o de Sepúlveda Everard. Tal projeto previa um edifício de alvenaria coberto de telhas, com 252 palmos de frente, 48 de fundos e que possuiria 20 quartos para enfermos, uma sala e outras acomodações.

Após as doações seguiu-se a construção do prédio de 13 quartos e 6 banheiras se prolongou por alguns anos, tendo em 1850, uma parte concluída e 
iniciada a sua ocupação, em caráter precário, até 1855, quando foram concluídas as instalações e montado o mobiliário. Neste ano, já estavam instaladas as 6 banheiras de mármore proveniente de Carrara - Itália, existentes até hoje em condições perfeitas e em uso permanente.

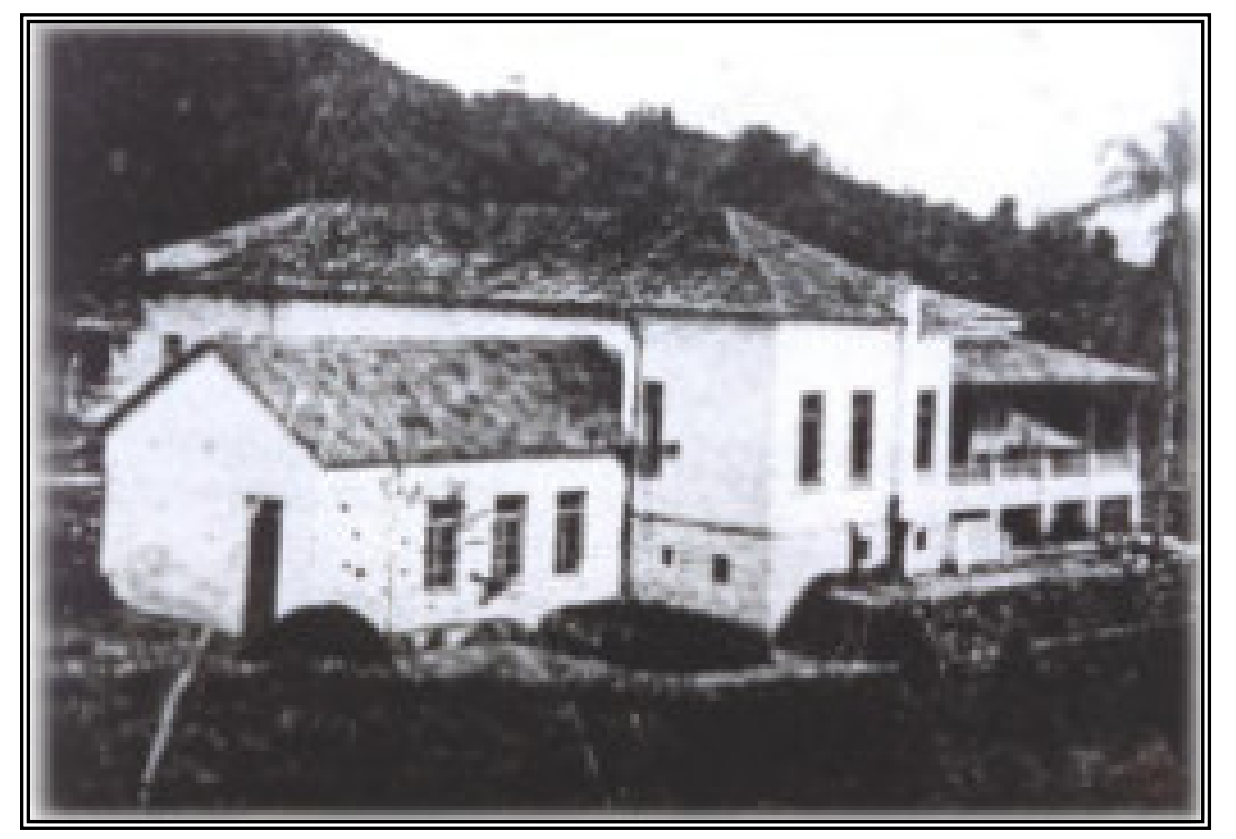

Fig. 9.7 - Vista das termas de Caldas da Imperatriz no Início do séc. XX.

Funcionou na condição de Hospital até um pouco antes de 1920, atravessando neste período, fases de grande movimentação e outras de completo abandono. As endemias rurais surgidas no período, desencorajavam o seu desenvolvimento.

Por volta de 1920, foi procedida uma ampla reforma no prédio original, passando a funcionar como hotel em regime de arrendamento. Iniciou-se também, a partir desta data, o engarrafamento da água e sua distribuição em Florianópolis. Em 1932, foram concluídas as obras de um prédio anexo com mais de 22 quartos e restaurante, sob a orientação de arrendatários, até o ano de 1976, quando a Companhia Hidromineral Caldas da Imperatriz, assumiu a administração da Estância Termal.

Através do manifesto $\mathrm{n}^{\circ}$ 1042/42 de 25/03/1942, foi dado ao Governo do Estado de Santa Catarina o direito de lavra das fontes Caldas da Imperatriz. No ano de 1976 a concessão de exploração da estância foi sustada pelo 
governo, que manteve o estabelecimento fechado por um ano e procedeu a uma ampla reforma. Em 1977, o Governo Estadual criou a Companhia Hidromineral Caldas da Imperatriz, que esteve subordinada a CODISC (Companhia Distrito Industrial do Sul Catarinense) e passou a concentrar 100 \% das ações da HidroCaldas, a qual, em seguida, passou para o controle da prefeitura, que firmou um contrato de compra e venda da Companhia, incluindo o hotel Caldas da Imperatriz.

Um ano após sua fundação, a Companhia participou de um processo de concessão para a empresa Itatiaia Empreendimentos Turísticos, que tem como nome fantasia Rede Plaza de Hotéis, possibilitando a construção do hotel, em funcionamento desde 1981. Fez-se também uma licitação para engarrafamento de água mineral, que resultou no contrato, já em execução, com a Companhia Catarinense de Refrigerantes, que hoje é representada pela empresa "Jan bebidas".

Atualmente, a "HidroCaldas" abastece, através de contrato, a Jan Bebidas, o Hotel Plaza e o Hotel Playontur. Além disso, a Companhia, considerada de economia mista, na prática é administrada pela Prefeitura, e responde por processos judiciais que colocam em risco o empreendimento, que, a qualquer momento pode voltar as mãos do Estado, tornando-se patrimônio da união.

Posteriormente, a denominação de Santo Amaro do Cubatão foi substituída pela de Cambirela, em virtude de um Decreto Federal de 1941, segundo o qual deveriam ser eliminadas duplicatas de nomes de cidades e vilas em todo o país. Insatisfeita com o novo nome, em finais de 1948, a comunidade organizou um abaixo-assinado, endereçado ao Governo, no qual propunha duas opções: Santo Amaro do Cubatão ou Santo Amaro da Imperatriz. No último trimestre de 1948, o Diário Oficial publicava a nova designação "Santo Amaro da Imperatriz".

A primeira emancipação do município de Santo Amaro da Imperatriz ocorreu através da Lei no 1.504 que foi publicada no Diário Oficial do Estado em 06/09/56. Tal lei não consta na Legislação de Santa Catarina, mas ficou valendo a lei n 253, publicada no Diário Oficial da Assembléia n¹57, de 9 de agosto de 1956. 


\section{4 - Águas Mornas}

O Município de Águas Mornas, distante $6 \mathrm{~km}$ de Santo Amaro da Imperatriz em sentido Oeste, teve a sua fundação oficializada no dia 19 de dezembro de 1961. No entanto a região teve a sua colonização iniciada por imigrantes alemães, que aportaram na Ilha de Nossa Senhora do Desterro, atual Florianópolis em 1847. Os 164 imigrantes católicos e evangélicos instalaram-se na Colônia Santa Isabel, na área ocupada hoje pelos municípios de Águas Mornas e de Rancho Queimado, e encontraram grande dificuldade em trabalhar nos solos pouco férteis. Além disso, surtos de malária dizimaram boa parte da população. Apesar das dificuldades, a colonização avançou e a cidade se transformou numa das mais famosas estâncias hidrominerais do mundo sendo comparada às estâncias de Vichy e Aux-Les Thermes, na França. (Fonte: Secretaria de Cultura do Estado de Santa Catarina).

Distrito criado com a denominação de Teresópolis, pela lei provincial $n^{\circ}$ 628, de 11 de junho de 1869, subordinado ao município de Palhoça. Em divisão administrativa referente ao ano de 1911, o distrito de Teresópolis figura no município de Palhoça. No quadro fixado para vigorar no período de 1939-1943, o distrito de Teresópolis permanece no município de Palhoça. Pelo decreto-lei estadual no 941, de 19-12-1961, o distrito de Teresópolis passou a denominar-se Queçaba. Em divisão territorial datada de 01 de julho de 1955, o distrito já denominado Queçaba figura no município de Palhoça.

Pela lei estadual $n^{\circ}$ 348, de 21 de junho de 1958, transfere o distrito de Queçaba do município de Palhoça por o de Santo Amaro da Imperatriz. Em divisão territorial datada de 01 de julho 1960, o distrito de Queçaba figura no município de Santo Amaro da Imperatriz. Elevado à categoria de município com a denominação de Águas Mornas, pela lei estadual $n^{\circ} 790$, de 19 de dezembro de1961, desmembrado de Santo Amaro da Imperatriz. Assim permanecendo em divisão territorial datada de 2003. (Fonte: IBGE e Secretaria de Cultura do Estado de Santa Catarina).

Em poços da região do município de Águas Mornas, localizada a norte da área pesquisada, foram observadas temperaturas de até $45^{\circ} \mathrm{C}$ (medida 
informal feita com termômetro laboratorial após bombeamento de 30 horas; a medida oficial foi feita pelo LAMIN após cerca de 15 horas de bombeamento, com temperatura de $41,6^{\circ} \mathrm{C}$ ) em um poço tubular com 65 metros de profundidade, feito ap lado de uma antiga caixa de captação e que foi rebatizada de "Fonte Crystal". A temperatura ainda permanecia subindo, mas os testes pararam após 30 horas de bombeamento.

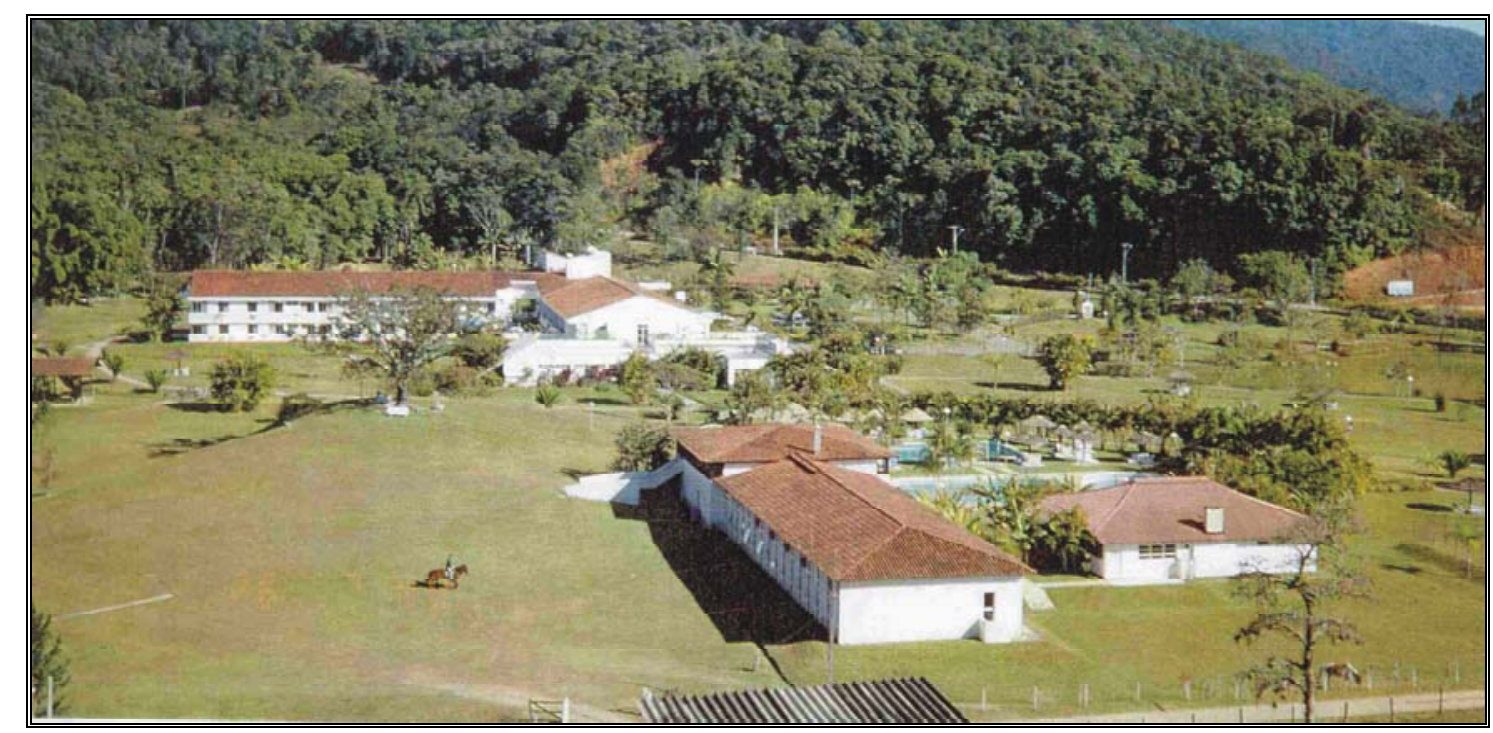

Fig. 9.8 - Vista geral das instalações do "Águas Mornas Palace Hotel" - Município de Águas Mornas. (fonte: GEOCON Geologia e Consultoria Ltda.)

Na foto 9.8 observa-se o Complexo hoteleiro de Águas Mornas, que atrai milhares de turistas todo os anos. O Compexo é abastecido com uma surgência natural captada através de caixa de captação e por dois poços tubulares profundos feitos posteriormente devido a exigência por maior volume de água.

O poço tubular profundo denominado "Fonte Crystal", após levantamento das principais ocorrências do Estado de Santa Catarina, foi caracterizado como possuindo a maior temperatura do Estado, superando em média $4^{\circ} \mathrm{C}$ das demais ocorrências hipertermais. 


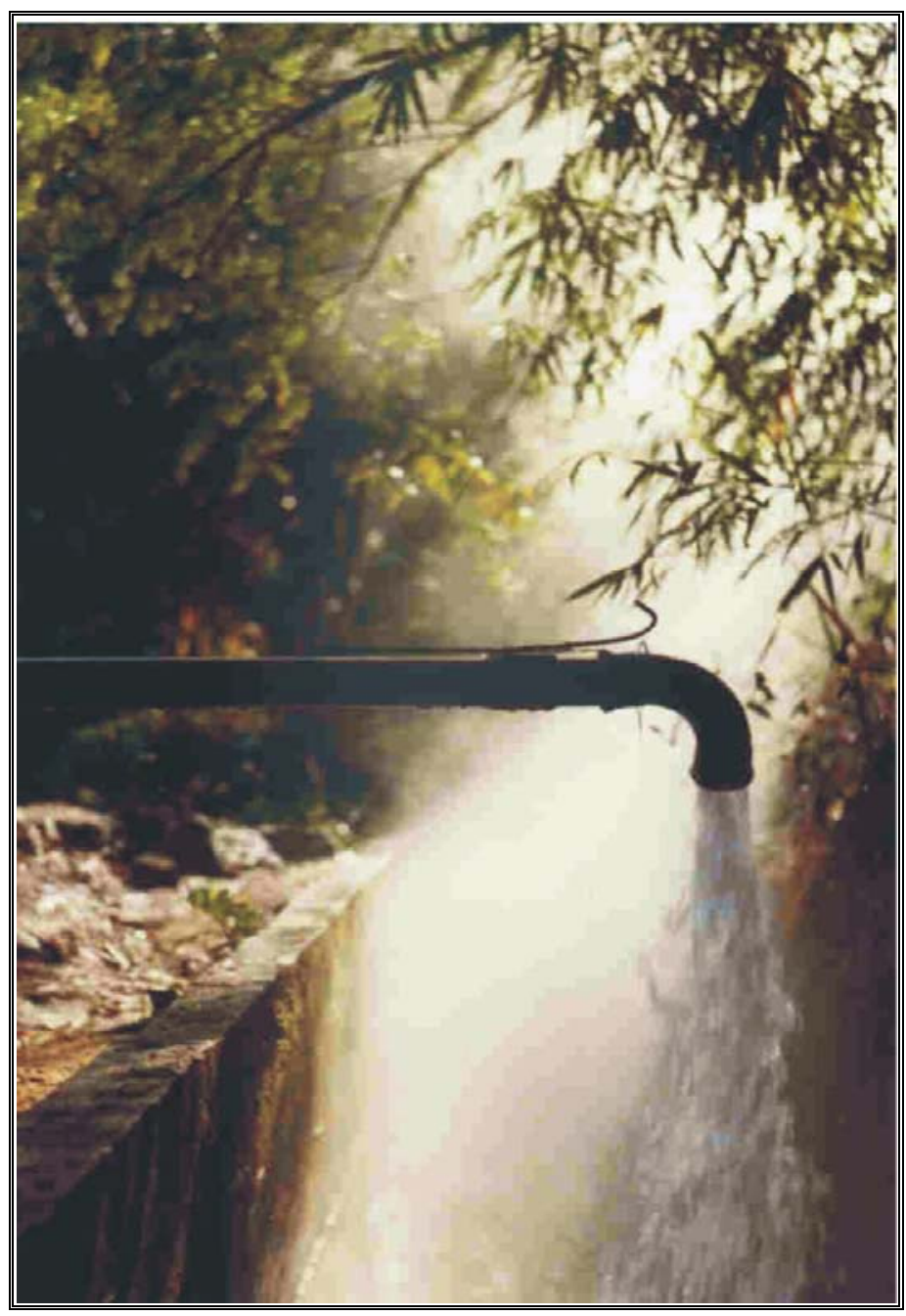

Fig. 9.9 - Fonte Crystal - Município de Águas Mornas. Temperatura inicial de 41,6, chegando a $45^{\circ}$ após 30 horas de bombeamento, o mais quente do Estado de Santa Catarina (Fonte: GEOCON Geologia e Consultoria Ltda.) 


\section{5 - Gravatal}

Gravatal constituiu-se município pela evolução da colônia de Santo Antonio dos Anjos de Laguna, sendo fundado por João Martins de Souza em 1842, que se estabeleceu no local, fez grandes lavouras de mandioca e cana-de-açúcar, construiu dois engenhos e dois alambiques e abriu estradas para carros de boi, que serviam para transportar os seus produtos para Tubarão, ou então se servia do rio, utilizando canoas para escoar a produção para Laguna.

Entre 1880 e 1885, chegaram as primeiras famílias de imigrantes italianos e em 1910, os alemães. Apesar da influência dessas etnias, a tradição açoriana dos primeiros colonizadores ainda é forte na cidade, tanto na arquitetura quanto nos hábitos populares. Gravatal pertencia a Tubarão até 1961 quando foi emancipado e transformado em município.

Hoje a principal atividade econômica baseia-se na agricultura e extrativismo mineral, destacando-se a pecuária, indústria de transformação e beneficiamento. O turismo, devido às suas águas termo-minerais, localizado no bairro Termas do Gravatal, é o mais importante fator da economia local.

A exploração das águas termo-minerais dá-se apenas em 1942, com a iniciativa do Sr. Pedro Zappelini, que comprou as terras próximas onde existia a ocorrência de uma surgência natural. Desta forma surge as Termas do Gravatal, que conta hoje com diversos hotéis e infra-estrutura para turismo. (Fonte: Secretaria de Cultura do Estado de Santa Catarina).

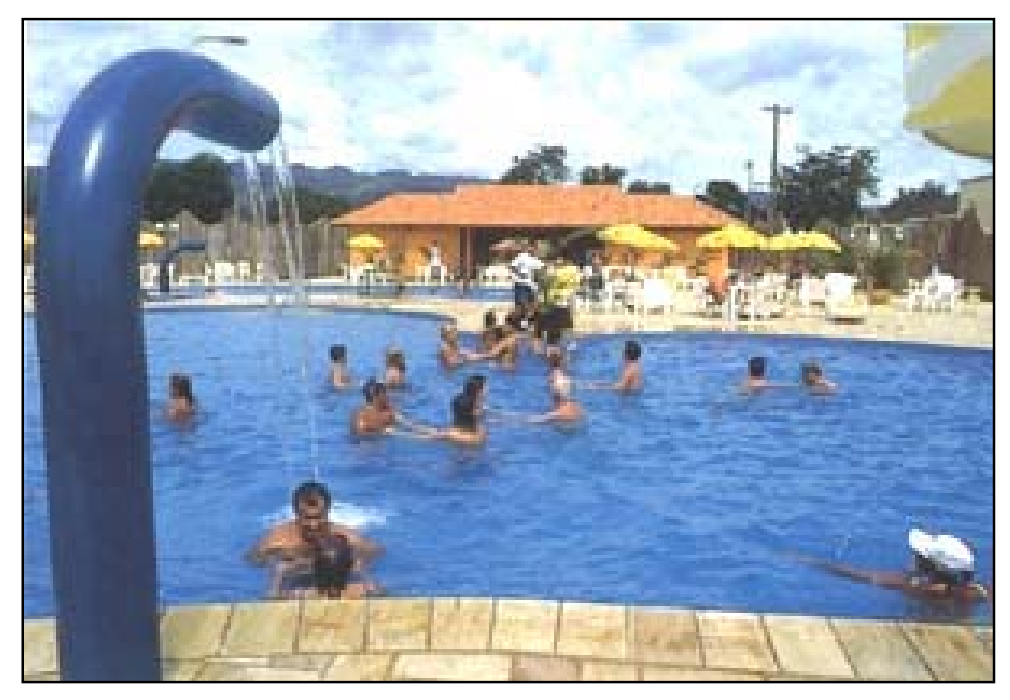

Fig. 9.10 - Vista das Termas de Gravatal. (Fonte: www.malhariaeliani.com.br/t ermas_gravatal.htm) 


\section{6 - Tubarão}

Em Tubarão as águas termais apresentam histórico curioso, teriam sido descobertas por um escravo foragido. As termas receberam o nome de "Termas da Guarda" em homenagem ao soldado Giuseppe Garibaldi, que teria montado guarda próxima a ocorrência, durante a Revolução Farroupilha por volta de 1840. Essa ocorrência foi comparada a água da fonte de Lourdes, na França e por isso recebeu o nome de Santo Anjo da Guarda.

A História de Tubarão inicia-se por volta de 1773, quando a Esquadra Espanhola fecha a barra da lagoa dos Patos, tornando-se necessária a abertura de outro caminho ligando Lages a Laguna, o que deu origem a Tubarão. A primeira denominação oficial foi Poço Grande do Rio Tubarão tornando-se $05^{\circ}$ Distrito de Laguna.

O povoamento de Tubarão está acentuado sobre duas bases históricas: A abertura do caminho entre Lages e Laguna (1773) e a Concessão de Sesmarias (1774). Em 5 de agosto de 1774, foram doadas duas Sesmarias, situadas no atual Perímetro Urbano: uma ao Capitão João da Costa Moreira, outra ao Sargento Mor Jacinto Jaques Nicós, sogro do primeiro. Esta é a data marco de povoamento. A partir de 1773 , da região serrana, desciam mulas carregadas de charque, queijo e outros produtos de menos importância que paravam no Poço do Rio Tubarão, também conhecido como "Paragem do Poço Grande", ou "Paragem de São João".

Os barcos, partindo de Laguna, subiam o rio transportando sal, tecidos, ferro e peixe seco. Atracavam no dito "Porto" do Poço Grande, onde trocavam as cargas, completando assim a rota Lages - Porto de Laguna. Naquela paragem e proximidade, tomavam-se necessárias às construções de algumas feitorias para dar abrigo aos viajantes, mercadorias, arreios e, por lógica, a morada obrigatória de famílias para dar a devida assistência.

Tanto Poço Grande, como o Poço Fundo, localizavam-se sobre a Sesmaria do Capitão João da Costa Moreira, o pioneiro fundador de Tubarão. Comprovadamente, o mencionado Capitão fez benfeitorias agrícolas sobre a sua sesmaria e a do sogro Sargento Mor Jacinto Jaques Nicós. Ambos requereram 
aquelas sesmarias, percebendo a importância estratégica da área. No ano de 1812, João Teixeira Nunes, residente em Laguna, comprou a sesmaria da herdeira do Sargento Mor Jacinto Jaques Nicós. Em 1829 doou uma área de 80 braças ao quadro, à Irmandade de Nossa Senhora da Piedade, com o objetivo de construir a Igreja, para servir de matriz, desde que se pleiteava a criação da paróquia. Por este motivo foi confundido como fundador da cidade.

O decreto $n^{\circ} 32$, do governo provincial, criou a Paróquia (Freguesia) Nossa Senhora da Piedade de Tubarão em, 7 de maio de 1836. Em 27 de maio de 1870, o presidente da Província sancionou a lei no 635 que criou o município de Tubarão, território desmembrado de Laguna. A comarca de Tubarão foi criada em 1875. Na década de 1870, registrou-se dois fatos: a imigração européia com predominância de italianos, seguida de alemães e outras nacionalidades, como também a formação da Cia Inglesa "The Donna Thereza Cristina Railway Co Ld."

O Topônimo Tubarão deriva do cacique Tub-Nharõ (do Tupi-guarani = pai feroz). Mais tarde Tubarão recebeu levas de imigrantes portugueses (açorianos e vicentistas), que descendem seu povo hospitaleiro e empreendedor. (Fonte: Secretaria de Cultura do Estado de Santa Catarina).

\section{7 - Pedras Grandes}

Localizada no Vale do Rio Tubarão, Pedras Grandes já foi ponto de parada dos tropeiros que faziam a ligação comercial entre os campos de Lages e Tubarão. Fundada em 28 de abril de 1877, com a chegada das primeiras 90 famílias de italianos, a cidade viveu um período de extremo desenvolvimento depois da descoberta das minas de carvão em Lauro Müller e da construção da estradade-ferro Dona Thereza Christina, quando foi erguida no município uma estação ferroviária - hoje transformada em Museu da Cultura Italiana. Foi elevada a distrito em 1888 e a município em 1961, quando se desmembrou de Tubarão. (Fonte: Secretaria de Cultura do Estado de Santa Catarina).

As ocorrências termais neste município foram pouco estudadas e não há exploração efetiva. 


\section{8 - Imaruí}

Localizada no Vale do Rio Tubarão, Imaruí foi colonizada antes de 1800 por um grupo de pescadores oriundos de Laguna. Em 1833, foi criada a Freguesia de São João Batista do Imaruí, que se tornou distrito de Laguna. Um dos colonizadores foi o gaúcho João Vieira da Rocha, que acompanhou os farrapos até Laguna e que mais tarde mudou-se para Imaruí em companhia dos filhos.

A guerra que se seguiu à instalação da República Juliana, onde ocorreu o trágico episódio da conhecido como o "Massacre de Imaruí" fez com que muitas famílias deixassem Laguna para morar em Imaruí, por volta de 1839. Imaruí passou à categoria de município em 27 de agosto de 1890, e o nome foi dado por uma tribo de índios que habitava o local: vem do mosquito "maruim", comum na região. (FONTE: Secretaria de Turismo de Santa Catarina).

Existe apenas uma fonte conhecida neste município e fica na localidade denominada de Águas Mornas, apresenta temperatura de $38^{\circ} \mathrm{C}$ e ocorre na forma de Surgência natural. Esta surgência foi captada por uma caixa de captação em concreto e posteriormente foram feitos dois poços tubulares profundos para otimizar a sua explotação. Atualmente pertencente a uma empresa de nome Mineralli Ltda. (Fonte: Secretaria de Cultura do Estado de Santa Catarina e GEOCON Geologia e Consultoria LTDA). 


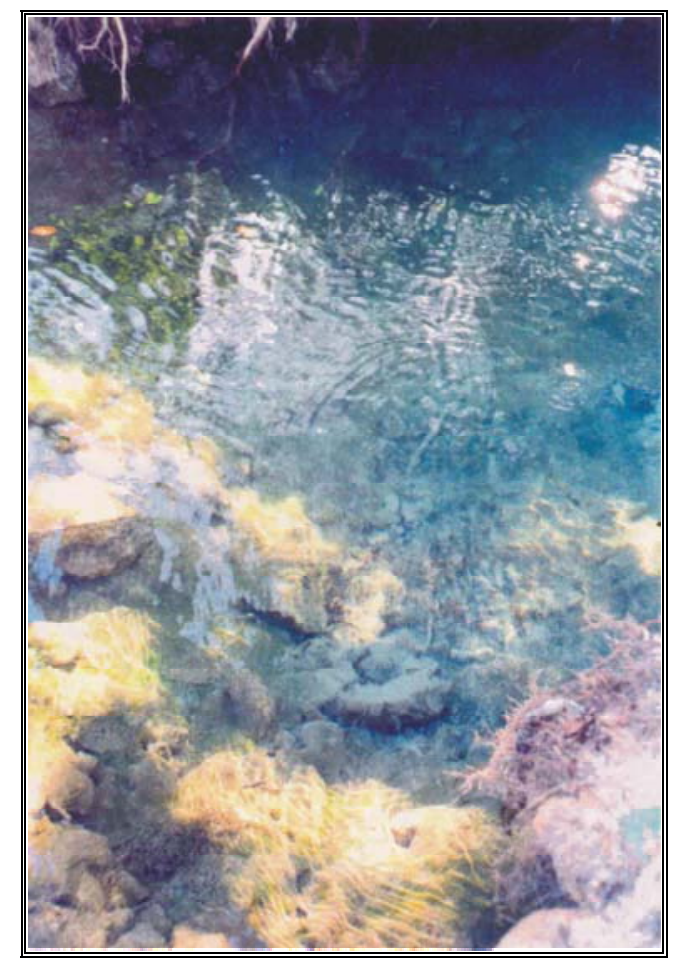

Fig. 9.11 - Vista da surgência no local denominado "Águas Mornas", no município de Imaruí, antes da construção da caixa de captação

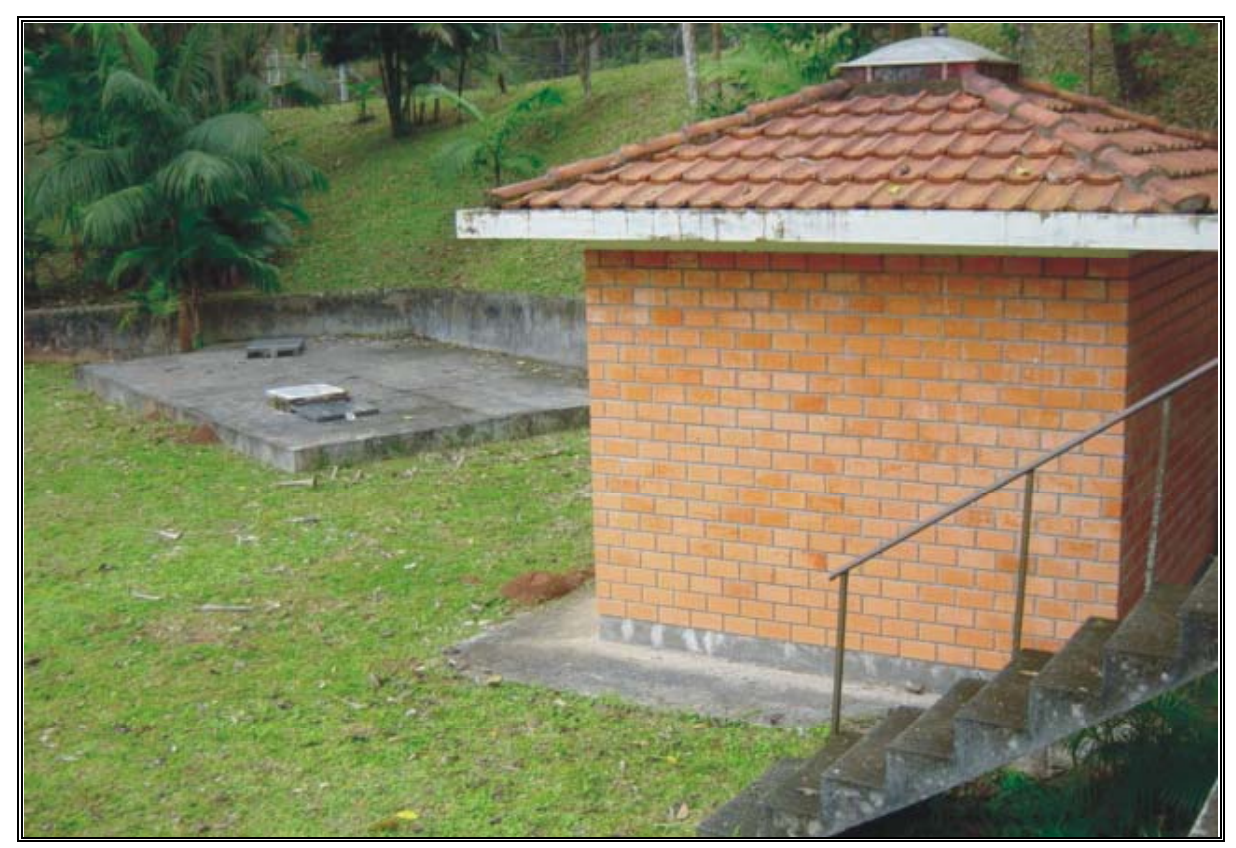

Fig. 9.12 - Vista da surgência no local denominado "Águas Mornas", no município de Imaruí, captada através de uma caixa de captação(a esquerda), posteriormente foi feito um poço tubular profundo a direita da foto, com casa de proteção. 


\section{9 - Modelos Genéticos propostos para as Águas Termo-minerais do Estado de Santa Catarina}

\subsection{1 - Modelo do Vulcanismo no Mesozóico - Triássico-Juro-Cretáceo}

Segundo ANDRADE JR. (1938) a gênese das águas de Caldas da Imperatriz, as quais se encaixam às surgências termo-minerais de Águas Mornas:

"A origem destas águas termais deve estar ligada ao grande derrame triássico que invadiu o sul do país e a cujo magma estão relacionados os basaltos vizinhos às fontes. Uma vez cessados os esforços orogênicos que determinaram a ruptura da crosta, ao mesmo tempo que tinha lugar a erupção do magma básico, precipitaram-se no banho fundido grandes massas ácidas já consolidadas que, sob a ação de altas temperaturas, deixaram escapar sua água de síntese que emerge na superfície pelo plano de contato entre granitos e os xistos cristalinos, através de um dique pegmatítico. Assim sendo, estas fontes devem ser consideradas como manifestações últimas da atividade plutônica assinalada na região de acordo com a teoria da gênese das águas termais de Arraud Gathier, Ocorrem ainda, outros argumentos em prol da origem profunda, quais sejam a constância da composição química e da temperatura, segundo observações de mais de um século e na radioatividade elevada dos gases espontâneos. Esta propriedade é geralmente característica das águas originárias do interior da Terra, onde se encontram concentrações de minerais radíferos".

TEIXEIRA (1969), faz uma relação entre as mineralizações de fluorita com as fontes termais ocorrentes na região centro-leste e assim se pronuncia:

"A mineralização de fluorita ocorre em fraturas abertas por movimentos tectônicos tensionais e renovação de antigas estruturas; a mineralização ocorreu próximo à superfície, havendo indícios de movimentação durante o processo de preenchimento. O controle estrutural dos filões é 
representando por fraturas com direções $N 40^{\circ}-60^{\circ} \mathrm{E}$, associados à falhamentos $\mathrm{N}$-S que afetam os depósitos do Grupo Tubarão". E complementa... "a explicação mais plausível para a origem destas mineralizações é que ocorreu durante ou no fim do período Paleozóico, associada à tectônica inicial da grande movimentação que precedeu os derrames basálticos da Bacia do Paraná; águas ascendentes ou mesmo parcialmente misturadas com águas superficiais, com grande conteúdo em flúor e sílica, depositaram-se e preencheram gradualmente fraturas abertas durante a movimentação".

\subsection{2 - Modelo do Vulcanismo Alcalino - Cretáceo Superior até o Eoceno}

WILLIG (1973), supõe uma origem a partir de manifestações residuais tardias, relacionadas à evolução do vulcanismo e plutonismo de idade Cretácea da Bacia do Paraná.

\subsection{3 - Modelo do Gradiente Geotérmico}

Segundo HURTER (1983), o modelo que melhor se aplica no estado de Santa Catarina seria explicada pela penetração das águas meteóricas no subsolo através de fraturas, sistemas de juntas e formações permeáveis e são aquecidas em profundidade, onde interagem física e quimicamente com o material rochoso. Após certo tempo de circulação estas podem emergir naturalmente em locais onde as condições forem favoráveis e, ao surgirem, possuem certa temperatura que depende dos seguintes fatores:

- Gradiente geotérmico regional

- Profundidade de circulação;

- Calor perdido na ascensão

- Grau de mistura com águas superficiais. 
A composição química, segundo HURTER (op. cit) contribui na geotermia e esta é governada pelos fatores assim destacados:

- Litologia do meio em que circulam as águas;

- Precipitação ocorrida no seu trajeto;

- Mistura com águas de outras composições;

- Velocidade de reação entre água e rocha;

- Temperatura existente em profundidades

Ainda da química se podem obter dados para serem usados em pesquisa de temperatura através de geotermômetros, como a sílica, o $\mathrm{Na}-\mathrm{K}-\mathrm{Ca}$, que tem suas taxas de dissolução ligadas à temperatura. Quando a perda de calor numa rápida ascensão das águas for pequena, de modo a alterar pouco a composição química das águas em questão, a análise dos elementos e minerais dissolvidos pode ser usada para inferir temperatura em profundidade.

Segundo BORGES (1994), em trabalhos de pesquisa na região, descreve que para as águas termais de Águas Mornas atingirem a temperatura de cerca de $41^{\circ} \mathrm{C}$ a profundidade mínima de origem destas águas deve ser calculado segundo a fórmula:

$$
P=(T s-T) \cdot G t
$$

Onde $\mathrm{P}$ é a profundidade de gênese, Ts a temperatura média de surgência em ${ }^{\circ} \mathrm{C}, \mathrm{T}$ seria a temperatura média da região e Gt o gradiente geotérmico. Para a região de Águas Mornas, BORGES (op. cit.), indica uma profundidade de ascendência que varia entre 960 a $1.280 \mathrm{~m}$. 


\subsection{4 - Modelo Genético Associado}

Este trabalho apresenta como hipótese o Modelo genético associado, que une os modelos já existentes, que em geral ligam o termalismo a apenas um evento genético, em uma seqüência de eventos contributivos que tem como resultado final o termalismo em questão.

Para este modelo foram analisadas quatro fases distintas de termotectonismo, começando pelo mais antigo, chamado de Ciclo Pan AfricanoBrasiliano que resultou em grandes lineamentos estruturais que possibilitaram o ratrabalhamento durante o Ciclo Brasiliano e chegando até o início do Cenozóico, com as últimas ocorrências vulcânicas expressivas em Santa Catarina.

Os lineamentos estruturais, regionais e locais foram plotados em um mapa estrutural que abrange toda a área pesquisada, onde foram subdivididas por direções NE, NW e NS. A direção EW não foi considerada por haverem pequenas ocorrência e sem expressão dentro do contexto analisado.

Estes milhares de lineamentos que foram agrupados e plotados no mapa estrutural tiveram como origem dezenas de mapas e centenas de horas de foto-interpretação, com isso pode-se obter um padrão de rompimento crustal com predominância de direção NE sobre a direção NW. Tanto uma direção quanto outra tem grandes estruturas regionais com dezenas e até centenas de quilômetros.

\subsubsection{1 - Primeira Fase Termo-tectônica}

Temos como primeira fase histórica a compartimentação tectônica da porção sul da província Mantiqueira, no Escudo Catarinense, que envolve duas unidades Tectônicas maiores, o Cráton do Rio de La Plata e o Cinturão Dom Feliciano (ZANINI, 1997), durante a fragmentação do supercontinente Rodinia (fig. 9.7 e 9.8). Nesta fase surgiram os grandes lineamentos continentais que foram necessários para a instabilidade crustal responsável em parte pelas fases seguintes. 


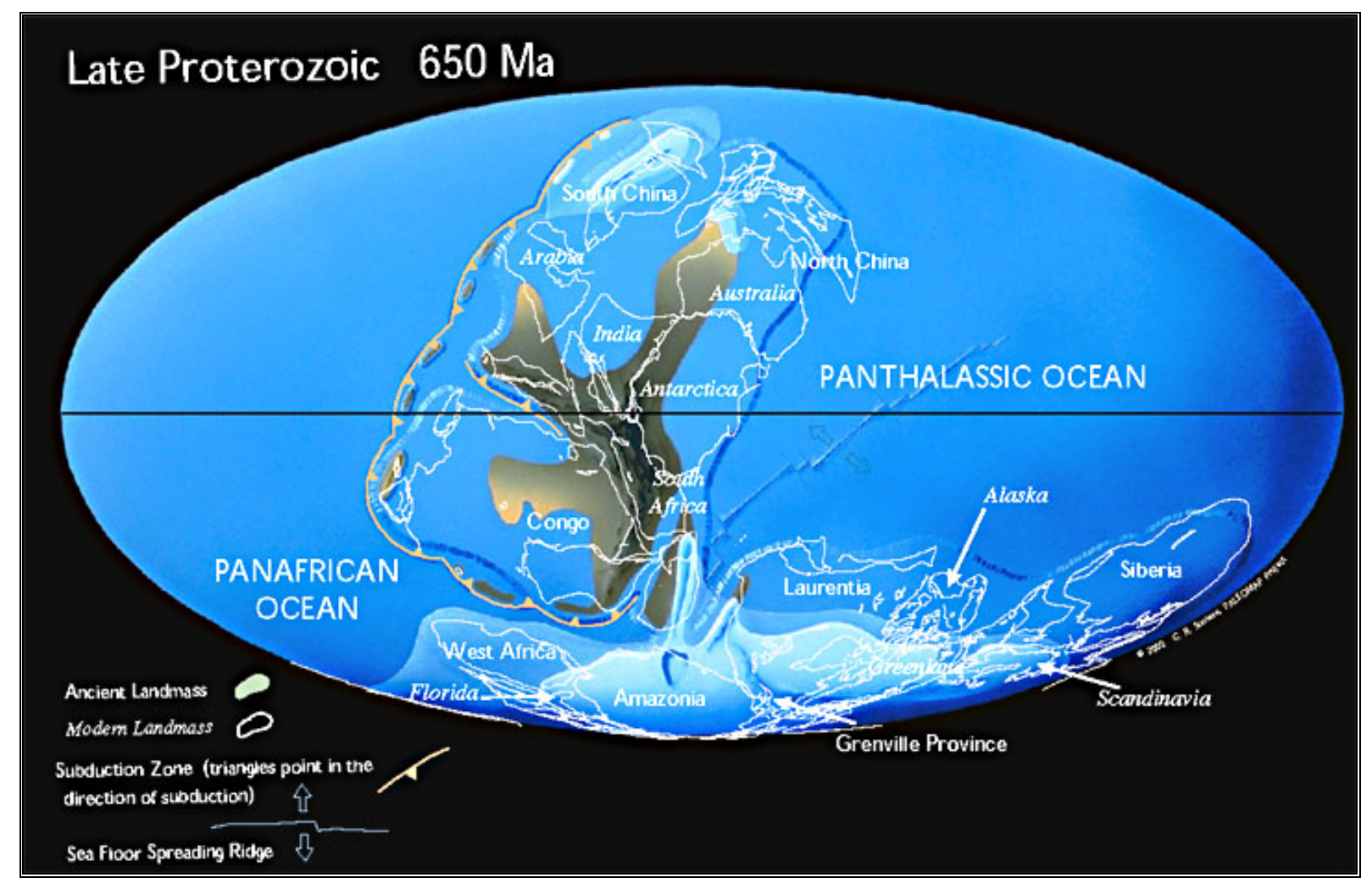

Fig. 9.13 - Mapa hipotético do supercontinente Rodinia. (fonte: http://www.scotese.com)

Alguns fragmentos de Rodínia (Gondwana Leste e Oeste e vários blocos menores) (Fig. 9.14) se movimentaram ao redor do globo e vieram estabelecer o megacontinente Gondwana, durante o evento Pan AfricanoBrasiliano.

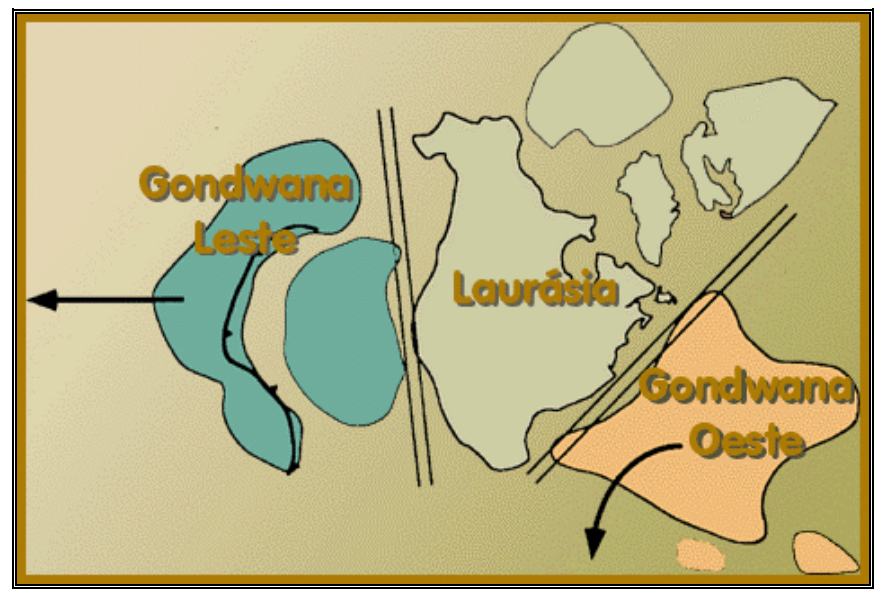

Fig. 9.14 - Configuração simplificada da distribuição dos blocos continentais após a quebra do Supercontinente Rodínia. (Modificada de ROGERS, 1996). 
A região que corresponde ao atual Continente Sul-americano era constituída de vários fragmentos cratônicos entre eles o Amazônico, São FranciscoCongo, Rio de la Plata, e vários blocos menores: Pampia, Central de Goiás, Juiz de Fora, Luis Alves, entre outros (UNRUG, 1996). As colagens entre esses blocos resultaram em diversas Faixas Móveis, dentre as quais podemos citar a Faixa Brasília (colisão entre o Cráton Amazônico e o Cráton do São Francisco (PIMENTEL \& FUCK, 1992) (Fig. 9.15).

Nos espaços entre esses blocos se desenvolveram riftes, aulacógenos e braços e/ou pequenos oceanos (BRITO NEVES, 1999), entre eles o Oceano Adamastor (HARTDANY et alli, 1985) entre o sudeste da América do Sul e o Sudoeste da África, representado pelos sedimentos da Faixa Dom Feliciano e parte da Faixa Ribeira.

Conforme os blocos continentais recém-partidos reiniciavam o processo de deriva continental, recomeçavam as colisões. No final do Período Cretáceo tem início as orogenias Alpina, na Europa (colisão entre África e Europa), Laramide, na América do Norte (colisão entre a placa do Pacífico e a América do Norte) e Mirano, na América do Sul (colisão entre a placa de Nazca e a América do Sul). 


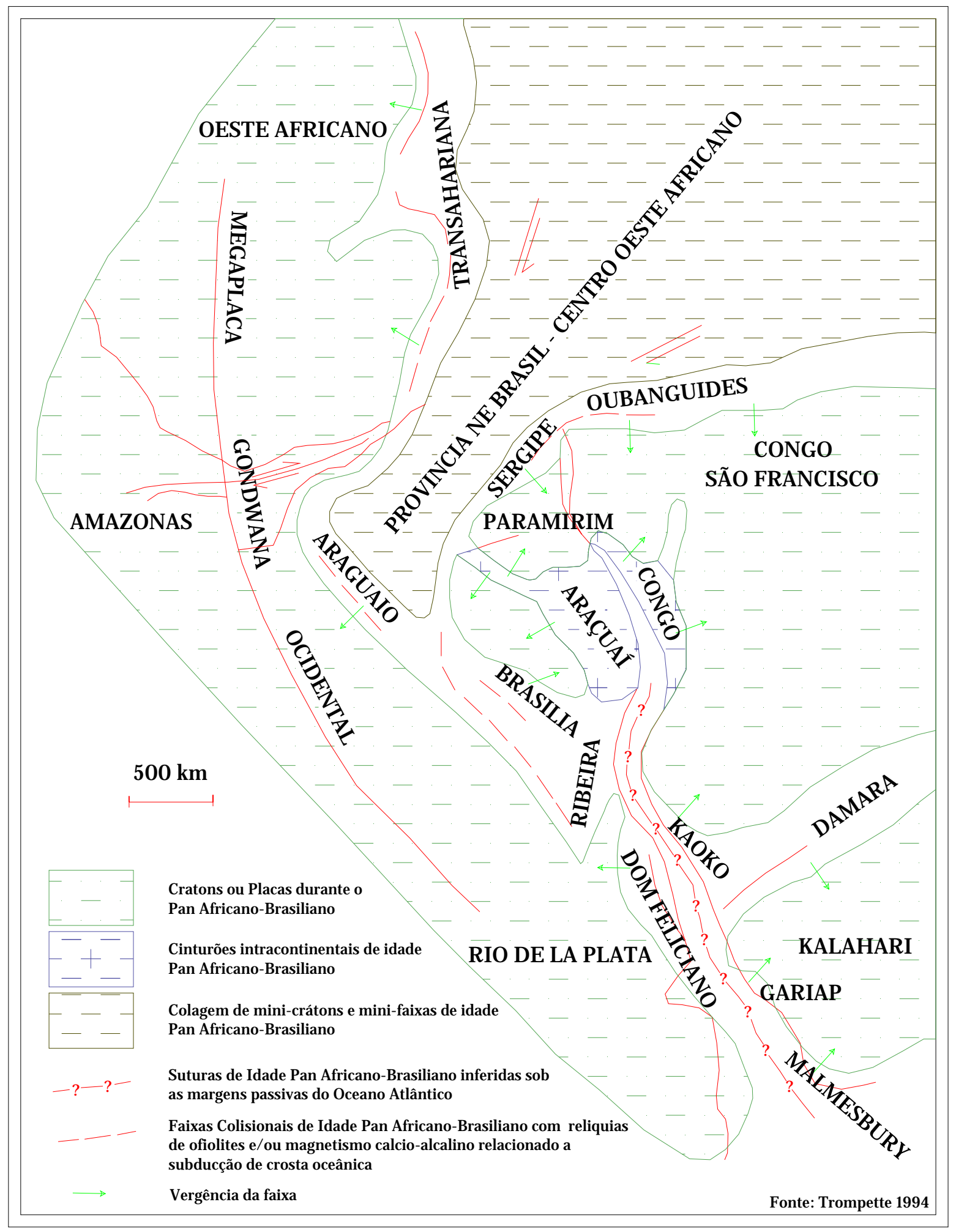

Fig. 9.15 - Geologia da porção inferior do Gondwana Leste (Ocidental) (600 Ma), com suas principais cadeias Pan-Africanas - Brasilianas e Crátons, em especial o Cinturão Dom Feliciano, que corresponde a Atual área pesquisada. 


\subsubsection{2 - Segunda Fase Termo-tectônica}

$\mathrm{Na}$ segunda fase temos o retrabalhamento do cinturão Dom Feliciano que corresponde a uma unidade geotectônica do Proterozóico Superior, durante o Ciclo Brasiliano. O Cráton Rio de La Plata, envolve os terrenos do Complexo Granulítico de Santa Catarina, que não chegaram a ser afetados pela orogenia termo-tectônica Brasiliana, e posteriormente serviu de antepaís para a evolução do Cinturão Dom Feliciano durante o Proterozóico Superior.

BASEI (1985) reconhece três domínios, tectonicamente compartimentados que definiu da seguinte maneira:

- Domínio Interno, onde predominam migmatitos e granitóides deformados, cortados por suítes graníticas, as quais chamou de Suíte Granitóide São Pedro de Alcântara e Suíte Plutonovulcânica Pedras Grandes.

- Domínio Intermediário, que engloba os metassedimentos deformados do Complexo Brusque e granitóides intrusivos das Suítes Valsungana e Guabiruba;

- Domínio Externo, representado pela antefossa molássica da Bacia do Itajaí, preenchida por sedimentos turbidíticos associados a magmatismo ácido.

BASEI (op.cit.), fez estudos geocronológicos realizados em amostras de rochas da Suíte Intrusiva Pedras Grandes, que corresponde, em parte ao Complexo Pedras Grandes (CASTRO e CASTRO, 1969; apud SILVA, 1987) e a parte granítica do Complexo Granito-gnaissico de SCHULZ Jr. E ALBUQUERQUE (1969).

Sob a denominação de Suíte Plutono-vulcânica Pedras Grandes, BASEI (op cit.), englobou as rochas granitóides que ocorrem como grandes batólitos intrusivos, do domínio interno do Cinturão Dom Feliciano, assim como também as rochas extrusivas e filonianas ácidas, como as do Morro do Cambirela e Ilha de Santa Catarina. Essas rochas foram datadas de cerca de $516 \pm 12 \mathrm{Ma}$. (para os granitóides) a $552 \pm 17$ Ma (para os tufos riolíticos do Cambirela). 
A intrusão dessas rochas graníticas resultou na reativação das câmaras magmáticas mais antigas geradas no proterozóico Superior.

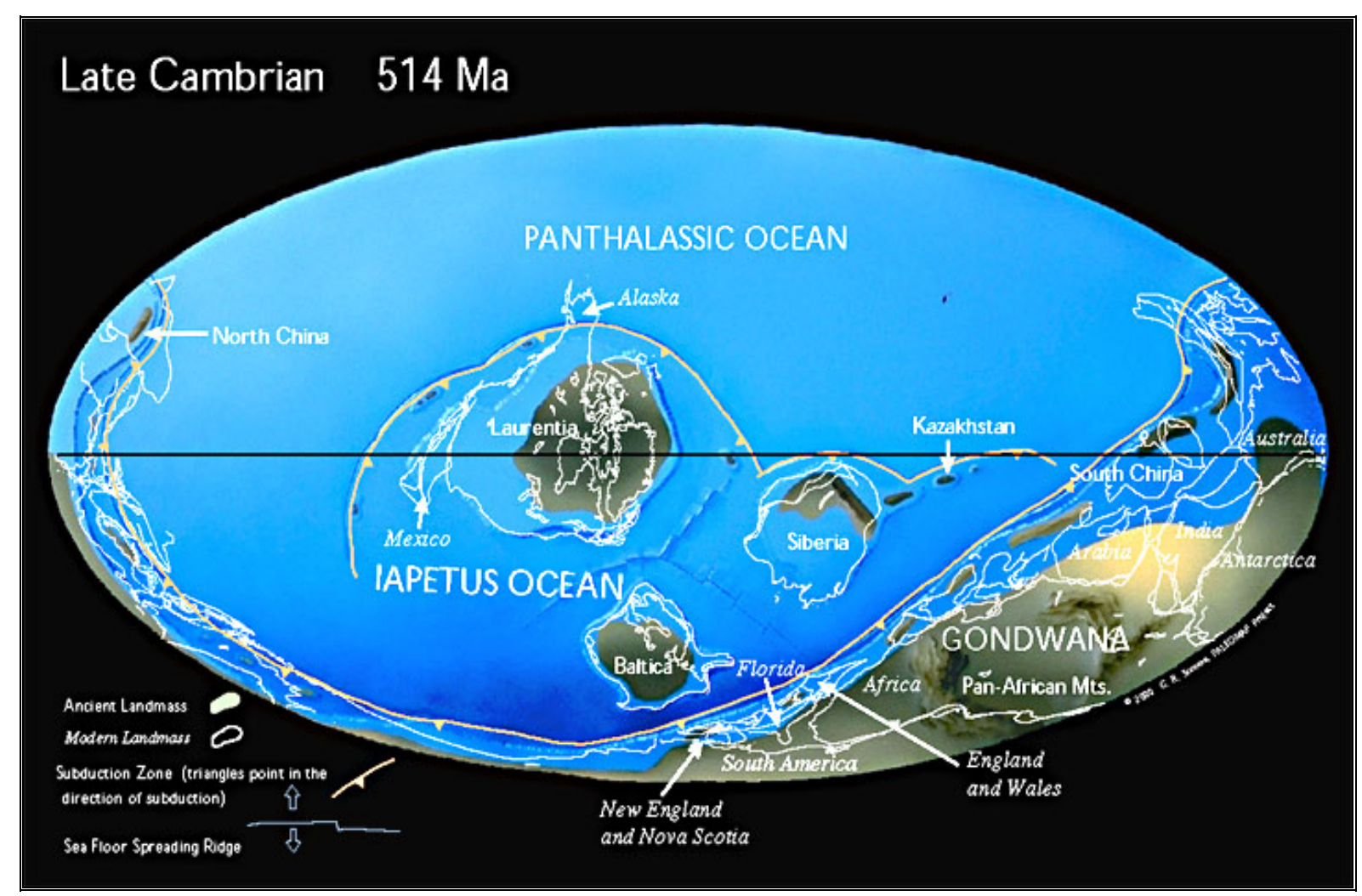

Fig. 9.16 - Reconstrução da provável posição das massas continentais no Cambriano Superior, 514 milhões de anos. (Fonte: $\underline{\text { http://www.scotese.com) }}$

Após o término da Orogenia Brasiliana, com o supercontinente Gondwana já constituído, o território brasileiro passou por uma fase de estabilização durante aproximadamente 300 milhões de anos, com 0 desenvolvimento de amplas bacias sedimentares intracratônicas (Bacias do Paraná, Bacia do Parnaíba e Bacia Amazônica) nas quais foram depositadas expressivas sucessões de rochas sedimentares, formando pacotes de centenas de metros de espessura. 


\subsubsection{3 - Terceira Fase Termo-tectônica}

A terceira fase termo-tectônica é iniciada no Triássico/Jurássico quando teve início a grande ruptura do supercontinente Gondwana em dois blocos com a separação dos atuais Continentes Sul-americano + Africano e dos continentes Antártida + Austrália, e a formação do Oceano Atlântico Sul.

A separação total entre a África e a América do Sul só ocorreu no final do Período Cretáceo, mas o processo de separação começou no final do Jurássico, gerando uma grande rifteamento ao longo da margem continental. Essa depressão foi entulhada de sedimentos, gerando seis bacias marginais: Pelotas, Santos, Campos, Espírito Santo, Bahia Sul e Sergipe - Alagoas. É nessas bacias que se armazenam os maiores depósitos de petróleo e gás do Brasil.

Esta separação promoveu a liberação de magma, formando extensos derrames de lavas basálticas sobre as unidades sedimentares paleozóicas. Com a ruptura, imensas fraturas surgiram, falhas tectônicas mais antigas foram reativadas, grandes áreas foram cobertas por lavas, outras subsidiram e começaram a receber sedimentos provenientes da erosão dos blocos soerguidos (CARNEIRO \& ALMEIDA, 1990).

Na Bacia do Paraná (que inclui parte dos Estados do Rio Grande do Sul, Santa Catarina, Paraná, São Paulo e Mato Grosso, além de parte do Uruguai, Argentina e Paraguai na América do Sul e da Namíbia na África) onde a extrusão teve maiores proporções, derrames emergiram de fraturas profundas e se empilharam sucessivamente formando uma espessura de até 1.700 metros na parte central da bacia (média em torno de 800 metros) e afetando uma área de mais de $1.200 .000 \mathrm{~km}^{2}$.

Nas demais bacias, esses valores são bem mais modestos, em torno de 400 metros na Bacia do Parnaíba e 700 metros na Bacia Amazônica, muitas vezes formando diques, ou interdigitando-se entre camadas sedimentares, formando soleiras.

As rochas basálticas no Sul do Brasil e no Uruguai são recobertas por lavas de composição mais ácida ou intercaladas com elas (CARNEIRO \& ALMEIDA, op. cit; ROISENBERG \& VIERO, 2000), do tipo riolito, riodacitos e dacitos. 


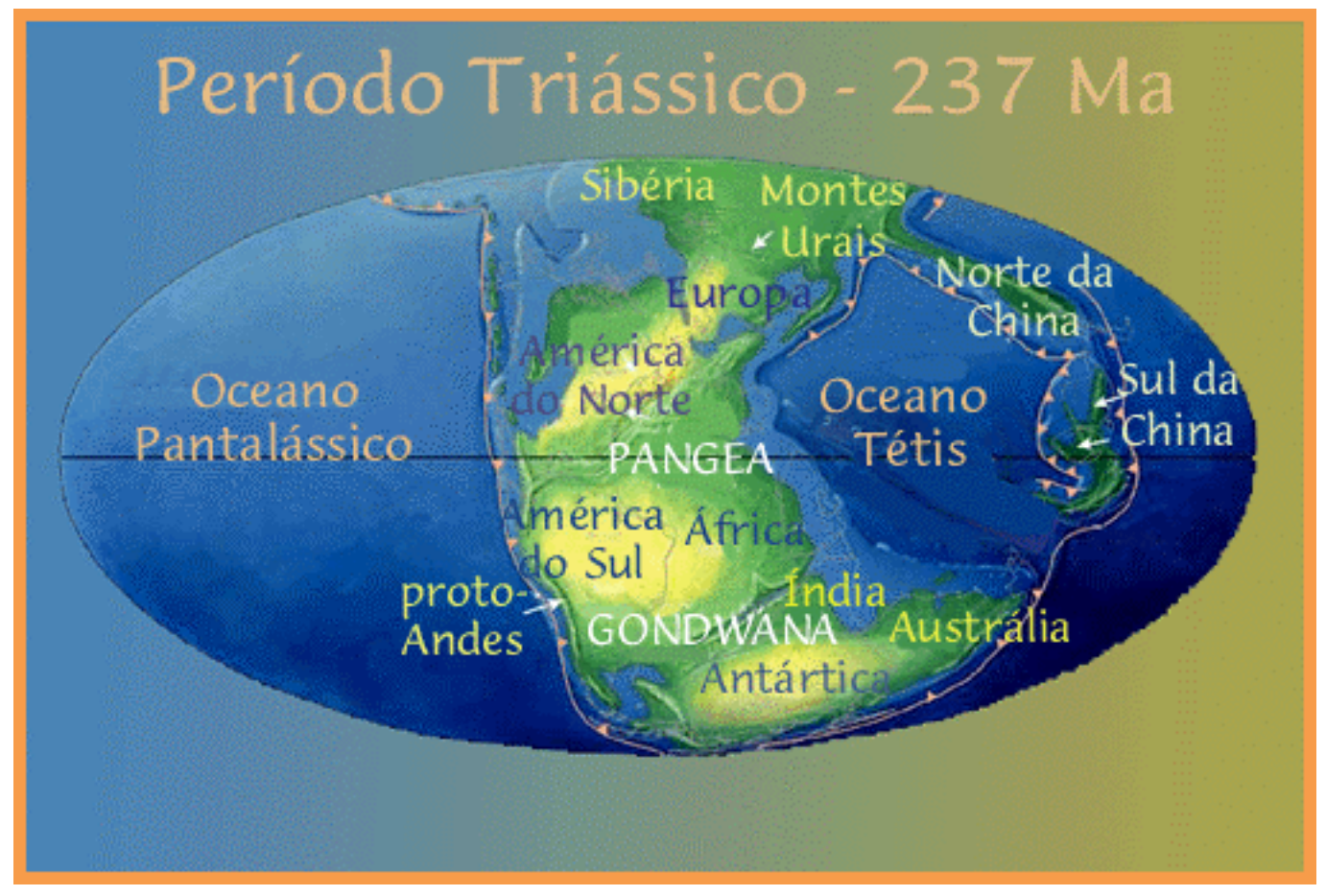

Fig. 9.17 - Reconstrução da provável posição das massas continentais no Triássico, 237 milhões de anos. Modificado de http://www.scotese.com. (fonte: http://www.fgel.uerj.br/Dgrg/webdgrg/Timescale/)

Foi durante este evento que parte das câmaras magmáticas antigas foram novamente reativadas, tornando possível a comunicação entre águas meteóricas e juvenis e com isso formando algumas fontes termo-minerais. Porém um evento mais recente é o que realmente forneceu incrementos para que esse hidrotermalismo fosse mais atuante nos dias de hoje. 


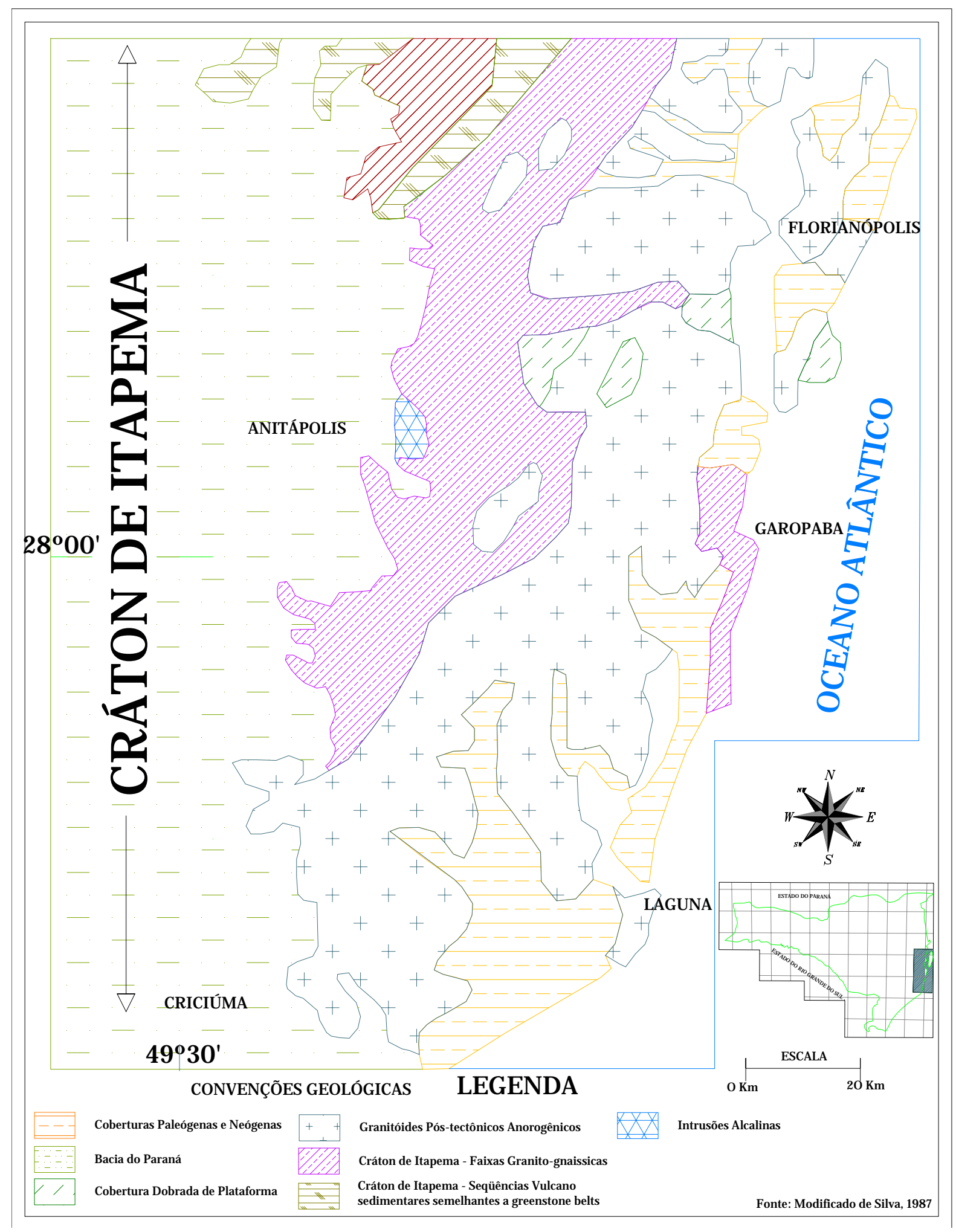

Fig. 9.18 - Compartimentação geotectônica da região estudada 
Um dos últimos grandes eventos na formação de rochas vulcânicas no Brasil ocorreu principalmente no final do período Juro-Cretáceo (entre 130 a 60 M.a) com manifestações tardias no Terciário Inferior (Eoceno). Esse período é marcado por um magmatismo mais alcalino identificado em várias porções do país, desde o sul até o nordeste. Os edifícios vulcânicos associados a estes corpos alcalinos foram em grande parte destruídos pela erosão, restando na maioria dos casos somente os seus equivalentes intrusivos ou subvulcânicos.

KUMAR (1981) supõe que o lineamento se prolongue para oeste pela chamada Dorsal de São Paulo, porém, a partir de $42^{\circ} \mathrm{W}$, encontra-se recoberto por sedimentos. A oeste, na direção do Lineamento de Florianópolis, ocorrem no Continente, não longe da costa, as intrusões alcalinas de Anitápolis (CARRARO et alli 1967) e de Lajes (SCHEIBE, 1978).

$\mathrm{Na}$ intrusão de Anitápolis, datada de 129 M.a (método de potássio/argônio (K/Ar), AMARAL et alli, 1967), associam-se ijolitos, melteijitos, urtitos e nefelina sienitos, além de carbonatitos locais. Na intrusão de Lajes, datada por SCHEIBE et alli (1985) em $82 \pm 6$ M.a (K/Ar), ocorrem nefelina sienitos, fonólitos, foiaitos e rochas ultrabásicas alcalinas.

Deve-se acrescentar ainda as pequenas intrusões de Quarenta (D'ELBOUX et alli 1982), inferidas por GUAZELLII \& CARVALHO (1981) como possível prolongamento, continente adentro, do Lineamento de Florianópolis. Nesta região, nenhuma perfuração, até o momento, atingiu rochas tipicamente alcalinas.

No sul do Brasil, o magmatismo alcalino se processou ao longo de estruturas soerguidas e falhadas marginais ou transversais aos limites da Bacia do Paraná, ou no interior desta (ALMEIDA, 1986). Alguns centros alcalinos são encontrados associados ao magmatismo fissural da Bacia do Paraná, no caso da área pesquisada onde ocorre o Complexo Alcalino de Anitápolis, com idade de 129 milhões de anos. 


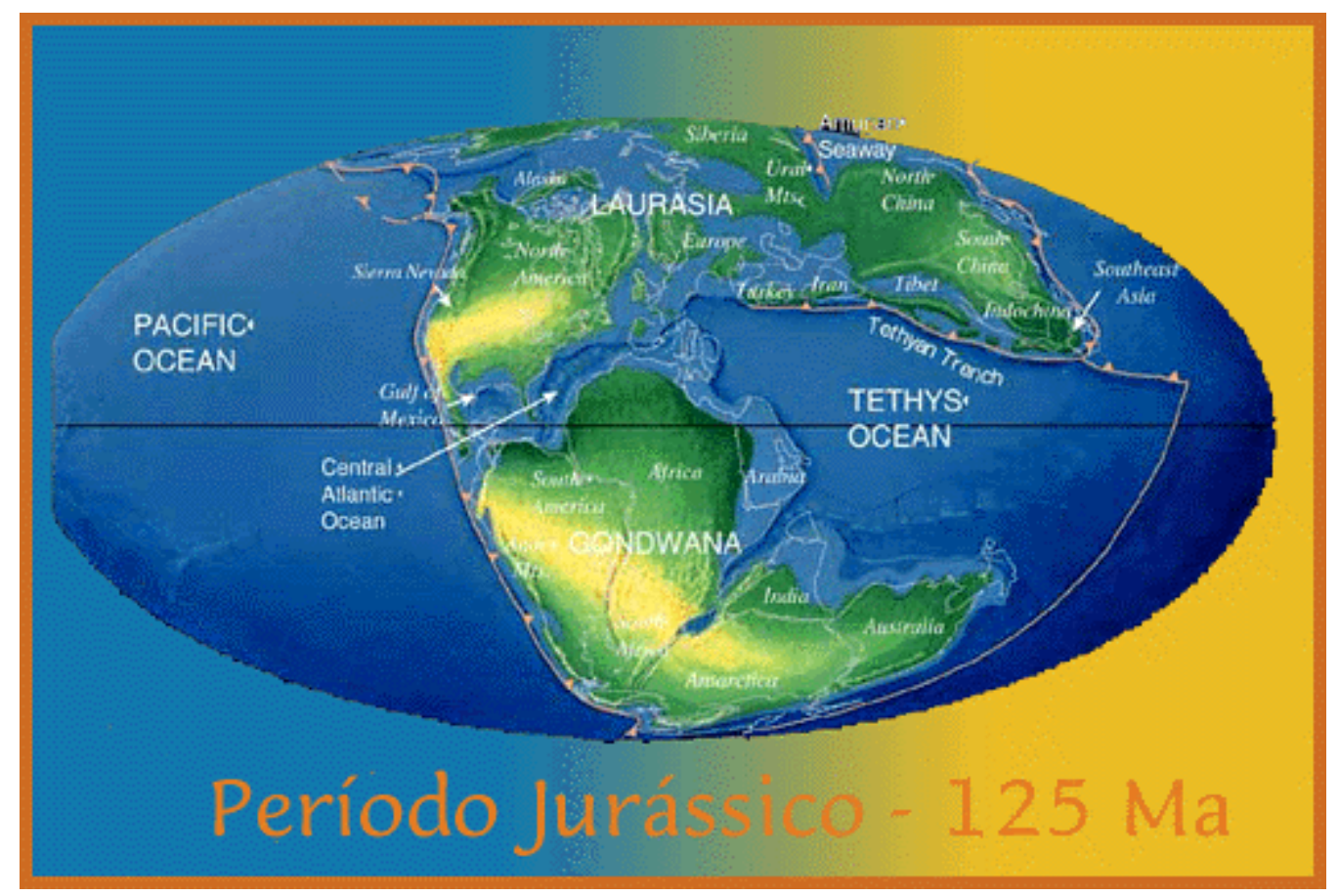

Fig. 9.19 - Reconstrução da provável posição das massas continentais no Jurássico, 125 milhões de anos. Modificado de http://www.scotese.com. (fonte: http://www.fgel.uerj.br/Dgrg/webdgrg/Timescale/)

Complexos alcalinos e carbonatitos alinham-se segundo lineações bem marcadas em Angola (África), Brasil, Sudoeste da África e Uruguai, lineações estas que coincidem com falhas transformantes centradas no pólo de rotação cretácico para a América do Sul (MARSH, 1973, RODRIGUES, 1974), que foram responsáveis pela separação dos continentes Sul Americano e Africano, após um estágio de rifteamento.

A Província alcalina da região meridional brasileira inclui desde grandes complexos, como os de Poços de Caldas $\left(800 \mathrm{~km}^{2}\right)$ e Itatiaia $\left(330 \mathrm{~km}^{2}\right)$, até pequenas chaminés vulcânicas, como a de Pântano $\left(<1 \mathrm{~km}^{2}\right)$. São conhecidos mais de 100 centros de intrusões de rochas alcalinas predominantemente mesozóicas, entre as quais, ao menos 20 deles incluem carbonatitos. Esses centros dispõem-se ao longo do arco em torno dos limites leste e nordeste da Bacia do Paraná e da região costeira marginal à Bacia de Santos, nos Estados de São Paulo e Rio de Janeiro. Os estudos geocronológicos indicam idades que agrupam-se em épocas relativamente distintas, desde idades sincrônicas ao vulcanismo mesozóico basáltico da Bacia do Paraná (133 e 130 Ma) até cenozóicas (80-50 Ma). 
O conhecimento dessas rochas se reveste de grande interesse econômico como também científico. Do ponto de vista econômico, os maciços alcalinos são as principais fontes de óxidos e/ou silicatos de nióbio, titânio, zircônio, urânio, tório, alumínio, berílio e sódio, além de importantes concentrações de fosfato de cálcio (apatita) e terras raras. Os maiores depósitos conhecidos no mundo de $\mathrm{Nd}$, terras raras, $\mathrm{Hf}$, e $\mathrm{Sr}$ estão relacionados com o magmatismo alcalino. Cite-se como exemplos brasileiros os depósitos minerais em nível comercial de fosfato [Anitápolis (SC), Araxá e Tapira (MG), jacupiranga e Juquiá (SP), etc.], titânio [Serra Negra e Tapira (MG)], zircônio e urânio (Poços de Caldas, hoje desativado), nióbio (Araxá). As reservas e demandas mundiais desses metais estão em contínuo crescimento, de modo que algumas variedades de rochas alcalinas poderão tornarse fontes de metais economicamente viáveis para futura exploração.

Em Santa Catarina, destaca-se como Complexo Alcalino tardio o Complexo Alcalino de Lages, com aproximadamente 80 milhões de anos de idade, onde afloram principalmente os equivalentes plutônicos e diques de rochas subvulcânicas fonolíticas.

Algumas dessas intrusões alcalinas estão alinhadas ao longo da estrutura soerguida conhecida como Arco de Ponta Grossa nos estados do Paraná e São Paulo o que permite pensar também na existência pretérita de centros vulcânicos também nessas regiões. 


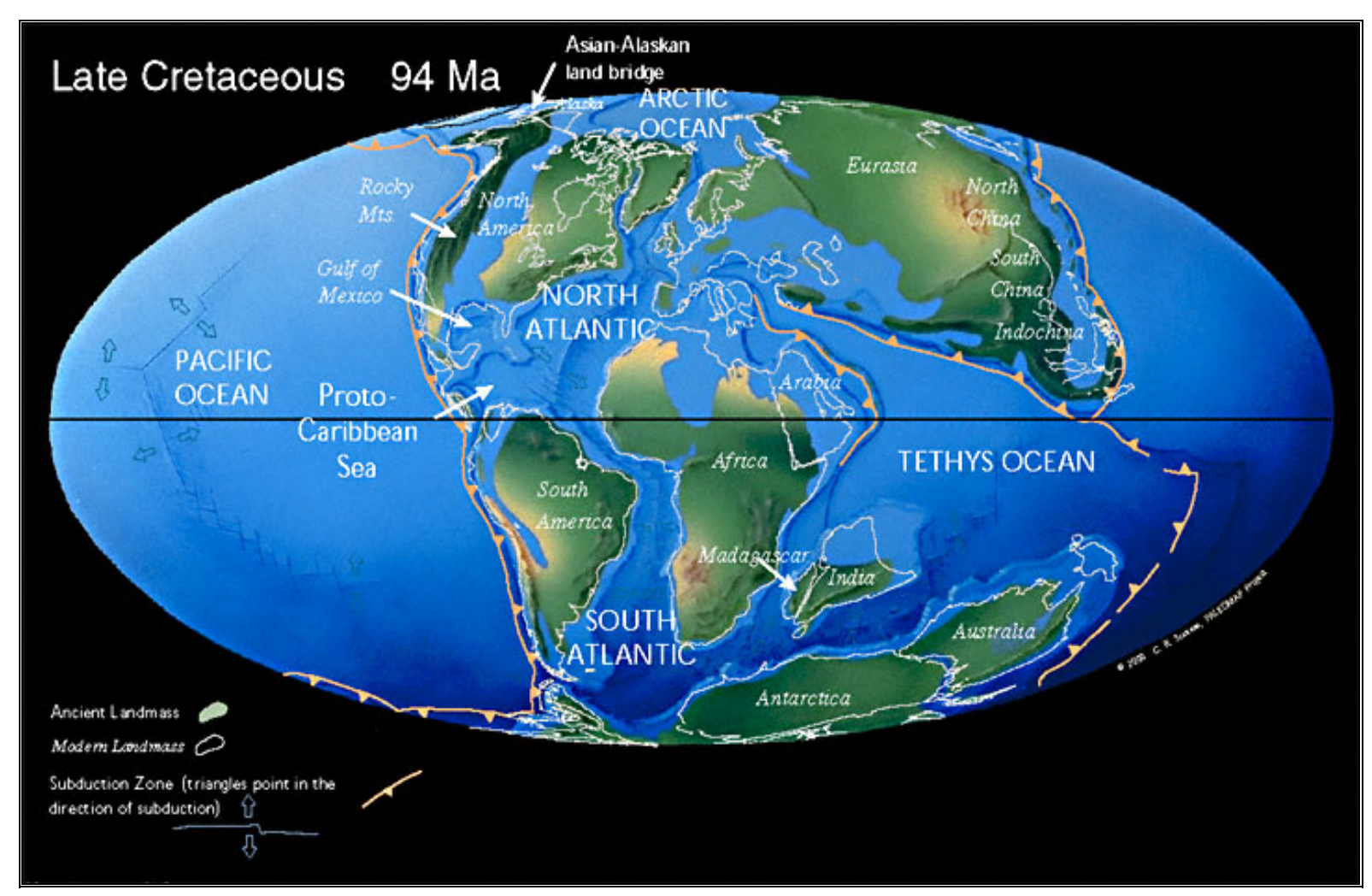

Fig. 9.20 - Reconstrução da provável posição das massas continentais no Cretáceo, 94 milhões de anos. (Fonte: http://www.scotese.com.)

Levando-se em conta a geologia regional, percebe-se a ocorrência de várias fases de reativação termo-magmática desde o Eo-paleozóico, mas principalmente no Juro-cretáceo com os derrames de rocha basáltica gerados pela separação dos continentes Sul Americano e Africano e fim do Cretáceo, na forma de intrusões alcalinas. Um último evento termo-magmático de menor escala seria a ocorrência de magmatismo terciário na forma de diques.

Na região sul do Estado de Santa Catarina, as ocorrências termominerais estão associadas a depósitos de fluorita hidrotermal, fornecendo fortes indícios de movimentos hidrotermais em rochas próximas às ocorrências. Os filões de fluorita estão encaixados em falhas abertas, com direção NS a N300E, que cortam quartzo-monzonitos, diques de quartzo-pórfiro e diabásio e sedimentos detríticos do Sub-Grupo Itararé (Carbonífero Superior). A precipitação química da fluorita ocorre na zona de "melange" (encontro dos fluidos descendentes e ascendentes), e estão vinculadas à última fase termo-magmática. (SAVI, 1980). 
A geologia da região sul da área pesquisada é bastante complexa com porções aflorantes do Escudo Catarinense com inúmeros corpos graníticos (fig. 9.21) e coberturas Fanerozóicas a oeste.

Os filões de fluorita encaixam-se preferencialmente nos granitos, desaparecendo, por estreitamento, ao penetrarem nas rochas sedimentares e soleiras de diabásio. A mineralização de fluorita é filoneana hidrotermal, sendo controlada por falhas e fraturas N-S a ENE-SSW (JELINKE et alli, 2003).

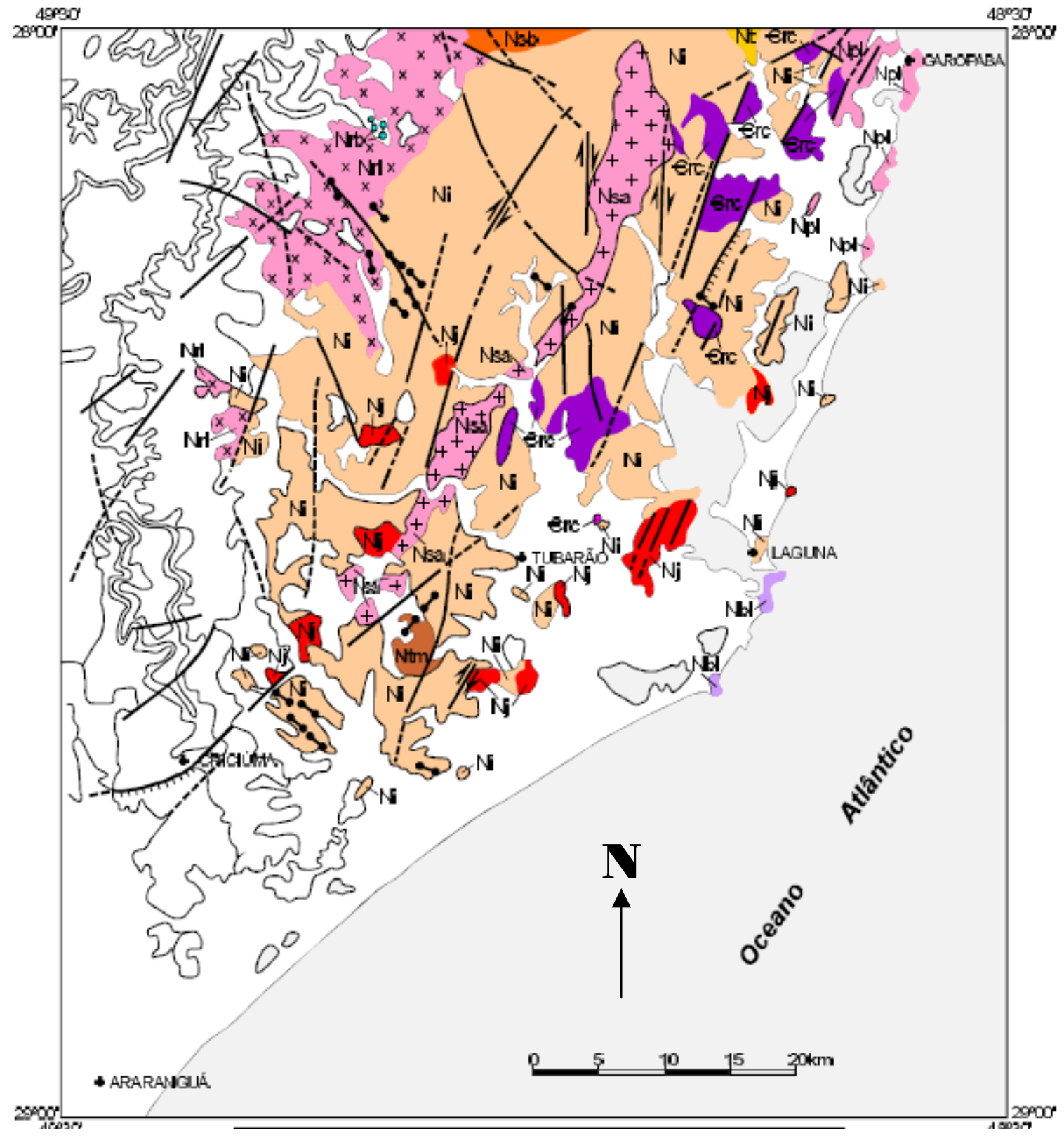




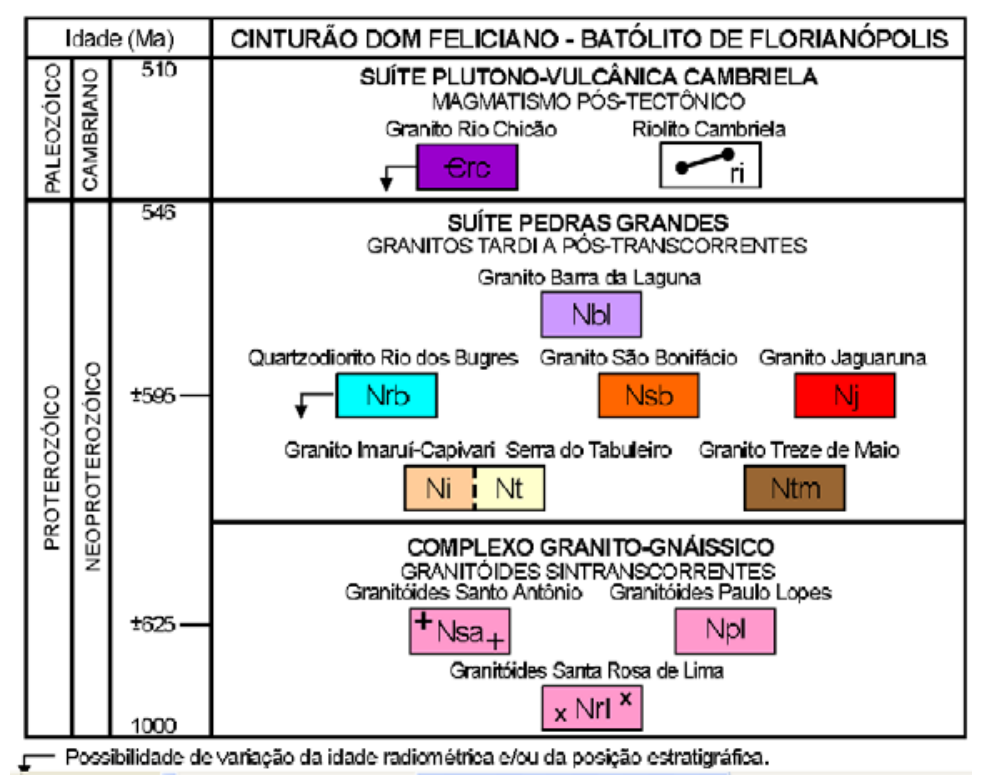

Fig. 9.21 - Unidades graníticas do Batólito de Florianópolis na Folha Criciúma.(SILVA, 2000)

Uma grande parte das ocorrências de águas termo-minerais brasileiras estão associadas a rochas formadas por este último evento, apenas como curiosidade podemos citar algumas grandes estâncias hidrotermais no Brasil, que se enquadram neste modelo:

- Caldas Novas - Goiás;

- Rio Quente - Goiás;

- Poços de Caldas - Minas Gerais;

- Caldas da Imperatriz - Santa Catarina;

- Termas da Guarda - Santa Catarina;

- Termas de Gravatal - Santa Catarina (entre outras).

Com isso é possível estimar que existam câmaras termais ativas capazes de gerar calor suficiente para garantir esse incremento na temperatura. Porém, devemos analisar que tais fraturas se consideradas as originais, sintectônicas, seria pouco provável que se mantivessem abertas do Eo-paleozóico ao Cenozóico. Seriam necessárias reativações dessas antigas fraturas, reabrindo antigos condutos e gerando novas câmaras magmáticas jovens o bastante para aquecer as águas meteóricas a temperaturas acima de $35^{\circ} \mathrm{C}$. Essas reativações seriam as fases 2, 3 e 4 acima mencionadas, que foram retrabalhando lineamentos tectônicos mais antigos e com isso mantendo as câmaras magmáticas ativas. 


\section{0 - CARACTERISTICAS SÓCIO-ECONÔMICAS DAS POPULAÇÕES NOS MUNICÍPIOS COM OCORRÊNCIA DE ÁGUAS TERMAIS E TERMO-MINERAIS.}

Em Santa Catarina foram caracterizadas nove áreas de produção de águas minerais e potáveis de mesa que se distribuem nas regiões leste, próximo à costa atlântica (Áreas 1 a 5) e noroeste/ sudoeste do estado (Áreas 6 a 9). Essas áreas compreendem processos ativos (31) e inativos (2). O predomínio absoluto é das águas minerais radioativas, fluoretadas, alcalino-bicarbonatadas, litinadas, sulfatadas, sódicas, sulfurosas e termais.

As captações na forma de poços e fontes apresentam vazões que variam de $1.000 \mathrm{l} / \mathrm{h}$ a $90.000 \mathrm{l} / \mathrm{h}$. O sistema aqüifero dominante é o fissural e o poroso.

O primeiro associado a rochas granitóides (granitognáissicas) e basaltos da bacia do Paraná. O segundo em litologias sedimentares (arenitos) do Botucatu e da Formação Rio do Rastro. No que se refere a produção, o estado de Santa Catarina alcançou, em 2003, a primeira posição na região sul, com pouco mais de 462 milhões de litros (DNPM - SISMINE /2004).

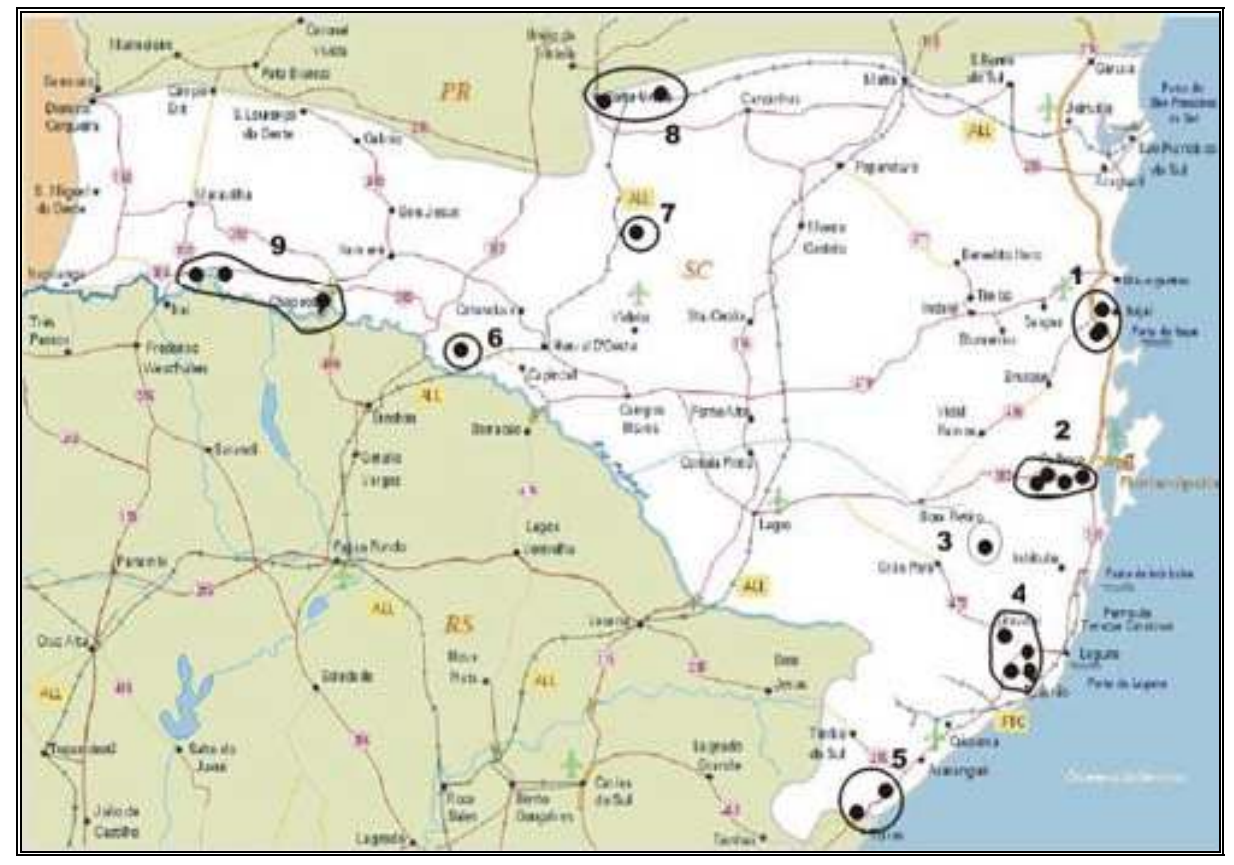

Fig.10.1 - Principais províncias hidrominerais em exploração no Estado de Santa Catarina (Fonte: DNPM - SISMINE / 2004) 
- Área 1 - Extremo Leste-Nordeste SC/Costa Atlântica"

- Área 2 - Extremo Leste SC/Costa Atlântica"

- Área 3 - Sul-Sudeste SC"

- Área 4 - Leste-Extremo Sudeste SC"

- Área 5 - Extremo Sul-Sudeste SC/Costa Atlântica"

- Área 6 - Oeste-Sudoeste SC/Bacia do Rio Uruguai"

- Área 7 - Norte-Noroeste SC"

- Área 8 - Extremo Norte-Noroeste SC/Fronteira Paraná"

- Área 9 - Extremo Oeste SC/Bacia do Rio Uruguai

As águas termais já ocupam uma posição de destaque no cenário nacional com $21 \%$ do total de captações registradas pelo DNPM em 2004.

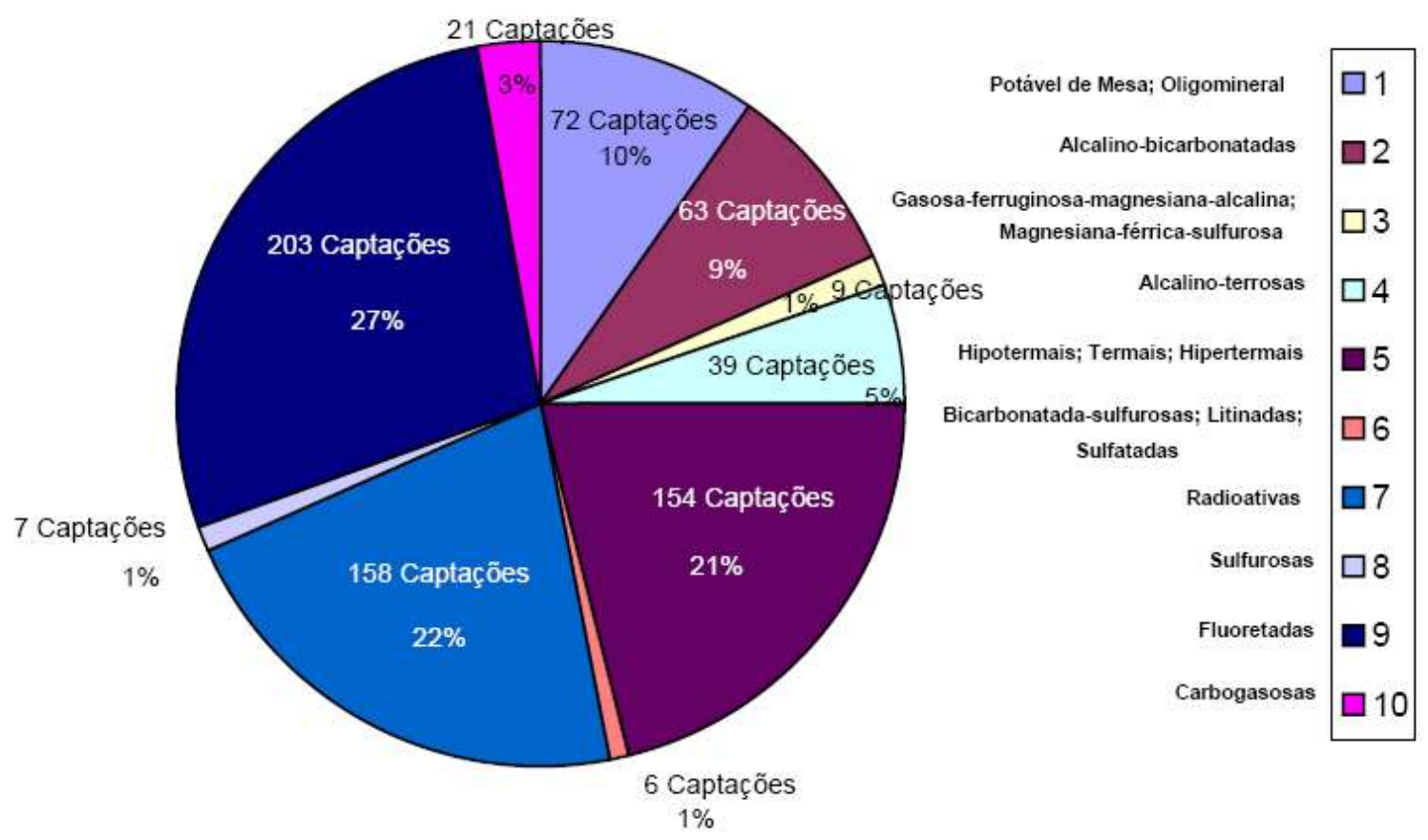

Fig. 10.2 - Relação entre o tipo de água e número de captações. (Fonte: DNPM)

Na tabela 10.1, pode-se observar a relação de processos de Água Mineral e Termo-mineral cadastrados no DNPM do $11^{\circ}$ distrito de Santa Catarina. 


\begin{tabular}{|c|c|c|c|c|}
\hline $\begin{array}{l}\text { PROCESSO } \\
\text { DNPM }\end{array}$ & $\begin{array}{c}\text { ÁREA DE } \\
\text { CONCENTRAÇÃO }\end{array}$ & $\begin{array}{c}\text { TIPO DE } \\
\text { CAPTAÇÃOO }\end{array}$ & $\begin{array}{l}\text { CARACTERIZAÇÃO } \\
\text { HIDROGEOQUÍMICA E } \\
\text { CLASSIFICAÇÃO }\end{array}$ & $\begin{array}{l}\text { CONTEXTO GEOLÓGICO E } \\
\text { HIDROGEOLÓGICO }\end{array}$ \\
\hline $\begin{array}{l}83 / 815310 \\
91 / 815166 \\
91 / 815117 \\
92 / 815389\end{array}$ & $\begin{array}{l}\text { 1-Extremo Leste- } \\
\text { Nordeste SC/Costa } \\
\text { Atlântica (Balneário } \\
\text { de Camboriu, Itajaí) }\end{array}$ & $\begin{array}{c}1 \text { Poço e } 1 \\
\text { Fonte } \\
2.400 \text { a } 6.085 \\
\text { 1/h Envase } \\
\text { Balneoterapia. }\end{array}$ & fluoretada & $\begin{array}{l}\text { Prov. Hidrogeol.: Escudo Oriental } \\
\text { SE Aqüífero fissural associado às } \\
\text { zonas fraturadas de rochas granito- } \\
\text { gnáissicas da Seqü.sup. do Comp. } \\
\text { Met. Brusque do Proterozóico Sup. }\end{array}$ \\
\hline $\begin{array}{l}72 / 809746 ; \\
72 / 804147 \\
85 / 815374 \\
89 / 815213 \\
92 / 815372 ; \\
94 / 815286 \\
94 / 815422 ; \\
99 / 815148 \\
99 / 815285 \\
01 / 815153\end{array}$ & $\begin{array}{c}\text { 2-Extremo Leste } \\
\text { SC/Costa Atlântica } \\
\text { (Palhoça, Águas } \\
\text { Mornas, Santo } \\
\text { Amaro da } \\
\text { Imperatriz, São } \\
\text { José, Barreiros); }\end{array}$ & $\begin{array}{c}6 \text { Fontes; } 5 \\
\text { Poços } \\
1000 \text { a } 83736 \\
1 / h \\
\text { Envase e } \\
\text { Balneoterapia }\end{array}$ & \begin{tabular}{|l||} 
1. frac. radioativa na fonte; \\
2. radioat.termal na fonte; \\
3. radioativa e hipertermal \\
na fonte; \\
4. fluoretada e radioativa e \\
hipertermal na fonte; \\
5. alcalino-bicarbonatada e \\
hipertermal na fonte; \\
6. fluoretada; \\
7. fluoretada e radioativa na \\
fonte
\end{tabular} & $\begin{array}{l}\text { Prov. Hidrogeol.: Escudo Oriental } \\
\text { Sudeste Aqüífero fissural associado } \\
\text { às zonas fraturadas de rochas } \\
\text { granitóides das suites intrusivas } \\
\text { Serra do Tabuleiro e Pedras Grandes } \\
\text { do Proterozóico Superior }\end{array}$ \\
\hline $92 / 815353$ & $\begin{array}{l}\text { 3-Sul-Sudeste SC } \\
\text { (Santa Rosa de } \\
\text { Lima) }\end{array}$ & $\begin{array}{c}2 \text { poços } \\
2500 \text { a } 15000 \\
1 / \mathrm{h} \text { Envase }\end{array}$ & $\begin{array}{l}\text { Fluoretada radioativa e } \\
\text { hipotermal na fonte }\end{array}$ & $\begin{array}{l}\text { Provi. Hidrogeol.: Paraná Aqüíf. } \\
\text { fissural associado às zonas frat. de } \\
\text { rochas granitóides intrusivas do } \\
\text { Batólito de Pelotas do Proterozóico } \\
\text { Superior }\end{array}$ \\
\hline $\begin{array}{l}41 / 2014 \\
41 / 4227 \\
41 / 4535 \\
42 / 1212 \\
75 / 805135 \\
88 / 815259\end{array}$ & $\begin{array}{l}\text { 4-Leste Extremo } \\
\text { Sudeste } \\
\text { SC(Armazém, } \\
\text { Gravatal, Pedras } \\
\text { Grandes/ } \\
\text { Urussanga, } \\
\text { Tubarão); }\end{array}$ & $\begin{array}{l}7 \text { Fontes e } 1 \\
\text { Poço } \\
1.015 \mathrm{a} \\
78.000 \mathrm{l} / \mathrm{h} \\
\text { Envase } \\
\text { Balneoterapia }\end{array}$ & $\begin{array}{l}\text { 1. radioativa na fonte; } \\
\text { 2.fracamente radioativa e } \\
\text { isotermal na fonte; } \\
\text { 3. fluoretada e hipotermal } \\
\text { na fonte; } \\
\text { 4.fluoretada e radioativa e } \\
\text { mesotermal na fonte; } \\
\text { 5.alcalino-bicarbonatada, } \\
\text { sódica e termal na fonte } \\
\end{array}$ & $\begin{array}{l}\text { Província Hidrogeológica: Paraná e } \\
\text { Escudo Oriental Sudeste Aqüífero } \\
\text { fissural associado às zonas } \\
\text { fraturadas de rochas granitóides das } \\
\text { suites intrusivas Pedras Grandes do } \\
\text { Proterozóico Superior }\end{array}$ \\
\hline $\begin{array}{l}85 / 815086 \\
90 / 815097\end{array}$ & $\begin{array}{c}\text { 5-Extremo Sul- } \\
\text { Sudeste SC/Costa } \\
\text { Atlântica (Sombrio, } \\
\text { São João do Sul) } \\
\end{array}$ & $\begin{array}{l}1 \text { Poço } \\
2.4001 / \mathrm{h} \\
\text { Envase }\end{array}$ & $\begin{array}{l}\text { Fracamente radioativa na } \\
\text { fonte }\end{array}$ & $\begin{array}{l}\text { Província Hidrogeológica: Escudo } \\
\text { Oriental Sudeste Aqüífero poroso } \\
\text { associado aos arenitos da Formação } \\
\text { Botucatu do Jurássico }\end{array}$ \\
\hline $86 / 815424$ & $\begin{array}{l}\text { 6-Oeste-Sudoeste } \\
\text { SC/Bacia do Rio } \\
\text { Uruguai(Piratuba) }\end{array}$ & $\begin{array}{c}1 \text { Poço } \\
\text { Balneoterapia }\end{array}$ & $\begin{array}{l}\text { Alcalino-bicarbonatada } \\
\text { e termal na fonte }\end{array}$ & $\begin{array}{l}\text { Província Hidrogeológica: Paraná } \\
\text { Aqüífero poroso associado aos } \\
\text { arenitos da Formação Botucatu do } \\
\text { Jurássico }\end{array}$ \\
\hline $\begin{array}{l}98 / 815481 \\
85 / 815056\end{array}$ & $\begin{array}{l}\text { 7-Norte-Noroeste } \\
\text { SC (Caçador) }\end{array}$ & $\begin{array}{l}1 \text { Poço } \\
7.0001 / h \\
\text { Envase }\end{array}$ & fluoretada & $\begin{array}{l}\text { Província Hidrogeológica: Paraná } \\
\text { Aqüífero fissural associado às zonas } \\
\text { fraturadas dos basaltos da Formação } \\
\text { Serra Geral do Grupo São Bento do } \\
\text { Jurássico-Cretáceo }\end{array}$ \\
\hline $\begin{array}{c}45 / 5156 \\
90 / 815270\end{array}$ & $\begin{array}{l}\text { 8-Extremo Norte- } \\
\text { Noroeste SC/ } \\
\text { Fronteira PR(Porto } \\
\text { União, Irineópolis) }\end{array}$ & $\begin{array}{l}1 \text { Poço } \\
7.9001 / \mathrm{h} \\
\text { Envase }\end{array}$ & $\begin{array}{c}\text { Alcalino-bicarbonatada } \\
\text { litinada }\end{array}$ & $\begin{array}{l}\text { Província Hidrogeológica: Paraná } \\
\text { Aqǘfero poroso associado aos } \\
\text { sedimentos arenosos da Formação } \\
\text { Rio do Rastro do Permiano Superior }\end{array}$ \\
\hline $\begin{array}{c}36 / 1829 \\
38 / 437 \\
76 / 803771\end{array}$ & $\begin{array}{l}\text { 9-Extremo Oeste } \\
\text { SC/Bacia do Rio } \\
\text { Uruguai(Xapecó, } \\
\text { São Carlos, } \\
\text { Palmitos) }\end{array}$ & $\begin{array}{c}4 \text { Fontes; } 1 \\
\text { Poço } \\
9972 \text { a } 28500 \\
\text { 1/h } \\
\text { Envase } \\
\text { Balneoterapia. }\end{array}$ & $\begin{array}{l}\text { 1. alcalino-bicarbonatada, } \\
\text { sulfatada e termal na fonte; } \\
\text { 2. alcalino-bicarbonatada } \\
\text { sódica; } \\
\text { 3.alcalino-bicarbonatada, } \\
\text { sulfatada e sullfurosa; } \\
\text { 4. sulfatada e mesotermal } \\
\text { na fonte }\end{array}$ & $\begin{array}{l}\text { Província Hidrogeológica: Paraná } \\
\text { Aqüífero fissural associado às zonas } \\
\text { fraturadas dos basaltos da Formação } \\
\text { Serra Geral do Grupo São Bento do } \\
\text { Jurássico-Cretáceo }\end{array}$ \\
\hline
\end{tabular}

Tab. 10.1- Processos de Água Mineral e Termo-mineral cadastrados em Santa Catarina Fonte: DNPM 


\section{1 - Santo Amaro da Imperatriz - Área 01}

O Município de Santo Amaro da Imperatriz situa-se no Sul do Brasil, à 35 quilômetros da cidade de Florianópolis, capital do Estado de Santa Catarina.Às margens da BR-282, é a principal ligação entre o litoral e o Planalto Catarinense. Sua população é de 16.896 habitantes (IBGE-2004). O Município possui uma extensão territorial de $352,4 \mathrm{Km}^{2}$, dos quais $63 \%$ correspondem à área de preservação, ou seja, Santo Amaro da Imperatriz tem uma topografia acidentada, com grande parte da sua área configurada pela Serra do Tabuleiro. Sua composição é de montanhas, morros e altiplanos.

A base econômica do município de Santo Amaro da Imperatriz é a agricultura, o turismo (com os balneários termais) e o comércio.

$\mathrm{Na}$ agricultura são bastante expressivos o cultivo do milho verde, tomate e hortaliças. Além disso, está sendo implantada a agricultura orgânica, que hoje já faz parte também da economia do Município. As culturas de maior produção no Município de Santo Amaro da Imperatriz são: batata, cana de açúcar, mandioca e tomate.

O Setor secundário é representado pelas indústrias de artefatos de cimento, envasamento de água mineral, moveleiras, madeireiras, serralherias, esquadrias de madeira e alumínio, além de uma indústria de fibras.

Segundo o RAIS - Relatório Anual das Informações Sociais, do Ministério do Trabalho, para o ano de 2001, as indústrias que trabalham com extrativismo mineral, no caso deste trabalho a extração de água subterrânea termomineral, na Grande Florianópolis ${ }^{1}$, são em número de 27 , com mais de 330 empregos diretos gerados.

Utilizam-se dados para a Região da Grande Florianópolis, e não para o Município de Santo Amaro da Imperatriz, simplesmente pela indisponibilidade de informações recentes sobre as atividades industriais desse

\footnotetext{
${ }^{1}$ Região da Grande Florianópolis é composta pelos municípios de: Águas Mornas, Anitápolis, Antônio Carlos, Biguaçu, Florianópolis, Governador Celso Ramos, Palhoça, Rancho Queimado, Santo Amaro da Imperatriz, São Bonifácio, São José e São Pedro de Alcântara.
} 
Município e pelo mesmo se localizar a apenas $38 \mathrm{~km}$ da Capital do Estado. (Fonte: Rais - Relatório Anual das Informações Sociais/Ministério do Trabalho e IBGE)

O setor terciário mostra-se representado pela presença de serviços diversificados. O destaque, nesse setor, vincula-se, todavia, às atividades que gravitam em torno da existência de fontes de águas termais. De fato, o município é conhecido, antes de tudo, como estância das águas termo-minerais radioativas que se destacam entre as melhores do mundo. Sua temperatura média, na fonte, é de $39,8^{\circ} \mathrm{C}$, o que a torna uma das mais altas do estado e do Brasil.

Esses atributos encontram-se na base de uma certa experiência turística de Santo Amaro da Imperatriz, tendo não só nas águas termo-minerais um atrativo, mas outras potencialidades naturais como montanhas, cachoeiras e rios que permitem o turismo de aventura, entre outros, com destaque para o vôo-livre, o rappel, a canoagem e o rafting.

No que se refere a educação, no ano de 2002 o Município de Santo Amaro da Imperatriz recebeu da Organização das Nações Unidas (ONU/EUA), o título de Município com melhor índice de qualidade na educação no Brasil. A ONU desenvolveu pesquisa no Município da Grande Florianópolis e outorgou o título com base do Índice de Desenvolvimento Humano (IDH). (DERNER, 2004)

\section{2 - Águas Mornas- Área 01}

A economia principal do município é a produção de hortaliças e em segundo lugar a explotação de águas termo-minerais, estas, porém tem potencial para tornar-se a principal economia local se o planejamento for efetuado e existir uma gestão desses recursos. O município conta com uma população de pessoas residentes segundo cadastro do IBGE, do ano de 2005 em 5.064 habitantes.

O município localiza-se distante cerca de $40 \mathrm{~km}$ da capital do estado, na margem direta da BR-282 e possui uma área total de $360,76 \mathrm{~km}^{2}$.

Como a própria denominação indica, o nome "Águas Mornas" vem das águas termais abundantes no lugar. A cidade tem seu desenvolvimento estruturado no turismo de saúde, recebendo anualmente milhares de visitantes de 
todos os pontos do Brasil, que vêm em busca da qualidade terapêutica de suas águas.

As informações são oriundas de pesquisas e levantamentos correntes do IBGE e dados de outras instituições, como Instituto Nacional de Estudos e Pesquisas, Ministério da Educação e do Desporto.

\section{3 - Gravatal - Área 02}

O município de Gravatal tem sua economia embasada no turismo das águas termo-minerais, muito conhecido na região. Com uma população de cerca de 11.000 habitantes, caracterizada como uma miscigenação de povos como Açorianos, Italianos e Alemães, principalmente.

O município localiza-se a cerca de 150 km de Florianópolis e apresenta uma extensão territorial de $194 \mathrm{~km}^{2}$.

Responsáveis pelo desenvolvimento turístico e econômico da região, as águas termais de Gravatal são consideradas as segundas do mundo, superadas em qualidade apenas pelo complexo de Aux-Les Therm, na França. Ela é explotada por sete hotéis instalados no complexo termal, a água jorra a uma temperatura média de $37^{\circ} \mathrm{C}$, com vazão de 40 litros por segundo. (Secretaria de Estado de Agricultura e Desenvolvimento Rural de Santa Catarina)

\section{4 - Pedras Grandes - Área 02}

Berço da colonização italiana no sul de Santa Catarina, Pedras Grandes é também antigo ponto de passagem de tropeiros. Pedras Grandes foi emancipada no dia 29 de dezembro de 1961.

A economia da região está embasada principalmente na agricultura, com destaque das culturas de fumo, batata, frutas como uvas, pêssegos e ameixas e em segundo lugar com a exploração das águas termo-minerais.

A população média de Pedras Grandes está em torno de 5.000 habitantes e a colonização é basicamente Italiana. 
A cidade localiza-se próximo ao município de Tubarão, estando distante $149 \mathrm{~km}$ de Florianópolis. (Secretaria de Estado de Agricultura e Desenvolvimento Rural de Santa Catarina)

\section{5 - Setores industriais para as águas Termo-minerais}

\subsection{1 - A indústria de água envasada}

A indústria da água envasada é atualmente uma das maiores no Brasil o no Mundo, pela crescente demanda de água de qualidade para consumo humano, já que as águas superficiais atingiram um elevado grau de degradação e sua recuperação torna-se cada vez mais difícil. As águas minerais uma vez engarrafadas tornam-se alimento, e portanto faz-se necessário falar um pouco sobre o setor alimentício.

Dentro do setor alimentício a água representa uma das matérias primas de maior valor econômico, apesar do baixo valor agregado, a água participa da maior parte dos processos de preparação e conservação de alimentos.

Segundo o DNPM, o panorama mundial do mercado de águas envasadas apresentado no "First Global Bottles Waters Congress", na cidade de Evian, França, em outubro de 2004, revelou que o consumo de águas deverá chegar a 206 bilhões de litros até 2008.

Destacam-se como líderes mundiais do mercado de águas envasadas a Nestlé Waters, seguida pela Danone, Coca-Cola e Pepsi, que detêm juntas $31 \%$ do mercado.

A Europa Ocidental apresentou em 2003, um volume de produção de 44 bilhões de litros, com uma média de consumo "per capita" da ordem de 112 litros/ano, seguida pela América do Norte, com produção de 26 bilhões de litros e média de consumo de 80 litros/ano, e América Latina, com 27 bilhões de litros e consumo de 50 litros/ano. Os maiores índices de consumo per capta ocorrem nos Emirados Árabes, com 223 litros/ano, seguidos da Itália com 189 litros/ano e França com 158 litros/ano. 
Considerando a produção individual de cada país, os Estados Unidos produziram 24,3 bilhões de litros em 2003, seguidos do México, com 13,8 bilhões, China, 11,8 bilhões, Itália, 10,8 bilhões, Alemanha, 10,6 bilhões, França, 9,5 bilhões, Indonésia, 7,9 bilhões, Tailândia, 5,3 bilhões e Espanha, 5,2 bilhões.

Há de se destacar que as estatísticas brasileiras referem-se exclusivamente à água mineral e potável de mesa engarrafada, enquanto na maioria dos demais países do Mundo, são também levadas em consideração a produção engarrafada de águas tratadas e adicionadas ou não de sais.

Há uma tendência mundial de aumento contínuo do consumo de água mineral e um amplo espaço a ser conquistado pela indústria nacional de águas envasadas que tem atraído grandes grupos das indústrias de bebidas e alimentos (Nestlé, Danone, Coca-Cola e Pepsi)

Com o objetivo de consolidar suas marcas de água, se estabelecer num mercado cada vez mais concorrido e de acompanhar as necessidades e preferências de um consumidor em busca de qualidade de vida, cada vez mais consciente dos benefícios da água mineral para a saúde do corpo, é fundamental agregar valor à água a fim de atender às exigências dos vários segmentos de mercado, observando padrões de qualidade, diversificação da linha de produtos, inovações em embalagens, marketing e bons serviços de distribuição aos clientes e consumidores.

O mercado brasileiro vem seguindo a tendência do resto do mundo com maior participação de águas sem gás e em embalagens acima de 10 litros.

Apesar do Brasil se destacar como um dos maiores produtores de água mineral, o consumo per capta/mês em torno de 23 litros é bastante reduzido.

O fenômeno crescente do consumo de águas minerais engarrafadas tem sua origem no termalismo, quando surgiram as primeiras indústrias de água no final do séc. XIX, com a moda dos grandes balneários termais, quando a aristocracia européia ia para estâncias como Bath, na Inglaterra, Ens na Alemanha ou Plombiers, na França, quando se apregoava que as águas tinham poderes curativos.

Com a chegada da II Guerra Mundial, a água deixa de ser vendida em farmácias como forma de medicamento e passa a ser vendida em larga escala em mercados e cafeterias, tornando-se assim um produto largamente consumido. 
Após essa mudança de hábitos associada a novas tecnologias na preparação de alimentos e bebidas, a água passa a fazer parte de muitas indústrias, em especial a indústria de bebidas gasosas, popularmente conhecidas como refrigerantes e bebidas fermentadas como a cerveja.

A indústria de água no Brasil é ainda singela e assegurar a qualidade de um produto tão frágil exige muito investimento em tecnologia e em pessoal altamente especializado. Esse investimento porém, deve ser feito com cuidado, pois a água ainda tem valor agregado baixo e necessita de grande volume para tornar-se rentável, além de monitoramento do setor em relação ao consumidor, acompanhando as tendências de consumo na região produtora em relação aos demais Estados.

Tendo em vista estes dados de crescimento, estima-se que as regiões que apresentam potencial hidrotermal tenham considerável crescimento econômico se desenvolverem um plano de gestão compatível com as normas legais.

\subsection{2 - A indústria dos Balneários}

O setor de Balneários no Brasil, apesar de antiga, com o surgimento da primeira Estância termo-mineral de Santo Amaro da Imperatriz em 1818, pouca novidade surgiu em termos de pesquisa e tecnologia para este setor.

Apesar de hoje o crescimento na procura dos balneários ter aumentado, em parte pelas mudanças de hábitos cada vez mais saudáveis e pelo aumento do número de horas de ócio em função da otimização de muitos setores de trabalhos ou mesmo do enriquecimento de determinadas populações, gerando estratos sociais com maior poder econômico e tempo ocioso (maior tempo de férias).

Também se pode atribuir aumento da procura se analisarmos do ponto de vista mercadológico com o surgimento de novas mídias e com isso aumentando o poder de expansão de novas idéias e produtos.

Porém, uma velha tendência, aos poucos embasadas em novas idéias, tem surgido e levado muitas pessoas a procurar os balneários, seria a idéia 
de que as águas termais e termo-minerais apresentam propriedades medicinais comprovadas, e não apenas atribuídas.

No setor de Balneários é importante definir uma estratégia competitiva, para obter uma posição sustentável, para isso é necessário investir em diferenciação ou especialização e simultaneamente oferecer bons preços para atrair o público consumidor.

Diferenciar-se significa oferecer um serviço único com instalações inovadoras, prestação de serviço inédito, novas tecnologias, ou até mesmo uma estrutura enxuta e simplificada.

A especialização pode ser atingida analisando-se o produto, neste caso as águas termo-minerais, e buscando nela algo que seja único, tanto por suas características físicas (temperatura, por exemplo), como químicas (ricas em algum elemento específico), ou posição geográfica distinta.

\section{6 - BREVE COMENTÁRIO SOBRE DESENVOLVIMENTO SUSTENTÁVEL E TURISMO ASSOCIADO ÀS ÁGUAS TERMAIS E TERMO-MINERAIS}

\subsection{1 - Conceitos}

O conceito de desenvolvimento sustentável, segundo AMÂNCIO \& GOMES (2001), tem três vertentes principais: crescimento econômico, eqüidade social e equilíbrio ecológico, induzindo um "espírito de responsabilidade comum" como processo de mudança no qual a exploração de recursos materiais, os investimentos financeiros e as rotas de desenvolvimento tecnológico deverão adquirir sentidos harmoniosos.

O desenvolvimento sustentável é um processo contínuo e, assim como toda atividade com fins lucrativos, não se pode garantir que a atividade turística seja totalmente sustentável. Afinal, os impactos negativos aparecem geralmente no médio e longo prazo, enquanto o mercado busca o lucro no curto prazo. A origem dos impactos resulta de um processo de interação entre turistas, comunidade e meio ambiente. Sendo o turismo uma atividade dinâmica, e como seus impactos e conseqüências mudam constantemente, é necessário seu monitoramento freqüente. 
Os impactos do turismo referem-se à gama de modificações ou à seqüência de eventos provocados pelo processo de desenvolvimento turístico nas localidades receptoras. As variáveis que provocam os impactos têm natureza, intensidade, direções e magnitude diversas; porém, os resultados interagem e são geralmente irreversíveis quando ocorrem no meio ambiente natural (RUSCHMANN, 1997). No que se concerne às influências na economia, o turismo pode representar positivamente e negativamente nos locais onde ocorre.

Assim como qualquer outra atividade, o turismo pode ser capaz ou não de estimular a economia e melhorar o nível de vida de uma população, com a geração de empregos, de renda, a expansão das oportunidades locais entre outros benefícios. Por isso, o mesmo não pode ser encarado como a solução para todos os problemas econômicos de uma região.

A dimensão hegemônica que o modo de produção capitalista reproduz, através da expansão da atividade turística, notadamente nos países do terceiro mundo, esta a exigir reflexão apurada a cerca das relações de custos e benefícios decorrentes do implemento desta atividade, como alternativa de Desenvolvimento Econômico (MORETTO, 1993).

Os recursos econômicos são fundamentais para que as regiões possam desenvolver a atividade turística. Para que os impactos econômicos sejam prevenidos é imprescindível que os benefícios sejam repassados pelas autoridades para a população que, na maioria das vezes, herda os impactos negativos que a atividade do turismo proporciona por falta de recursos. Além disso, o mesmo deve assegurar uma infra-estrutura necessária. Deve-se fazer uma análise na determinada localidade, de um conjunto de elementos que mostrarão seu potencial de desenvolvimento turístico.

No que se refere à infra-estrutura, faz-se necessário a conservação e melhorias nas estradas, rodovias e redes de energia elétrica para o interior além de soluções aos problemas do saneamento básico e conscientização da população quanto a mudança de postura em relação aos esgotos clandestinos, lixo nos rios, a utilização de agrotóxicos, como também, a extração desordenada de areia do fundo dos rios.

No que diz respeito à infra-estrutura social, enfatizar os recursos humanos, medicamentos e equipamentos na área da saúde. Quanto à educação, 
observar nas escolas programas de educação ambiental e conscientização para o turismo, laboratórios de informática e outros. Quanto ao turismo em si, avaliar o sistema de sinalização e estabelecimentos de critérios de uma política auto sustentável, enfocando o meio ambiente. A mão de obra e o nível de renda da população local são também elementos muito importantes a serem analisados.

A atividade turística pode trazer para a localidade/região onde é desenvolvida, além dos impactos econômicos, impactos sociais. Tais impactos podem ser benefícios como a diminuição do índice de desemprego, capacitação da mão de obra, desenvolvimento da estrutura urbana, além de outros. No entanto, além dos benefícios existem os prejuízos que, podem ser a imigração desordenada, o acúmulo de lixo rural e urbano, exploração do turista dentre outros.

No que se concerne à cultura, é importante assinalar que existem muitas culturas diferentes, que passam a ser elemento de atratividade das nações e de regiões específicas dentro de um mesmo país. Os impactos culturais podem ser favoráveis quando associados à valorização do artesanato local, da herança cultural e da preservação do patrimônio histórico. Sobre a questão ambiental, os impactos do turismo sobre o meio ambiente podem ser positivos quando há uma utilização racional dos recursos naturais e planos ou programas de conservação e preservação de áreas naturais, de sítios arqueológicos e, ainda, de monumentos históricos.

A promoção de descobertas e acessos a lugares não explorados através do ecoturismo e a recuperação psicofísica dos turistas são outros impactos favoráveis do turismo. No entanto o turismo também acarreta impactos ambientais negativos como a ocupação desordenada e a poluição de áreas naturais devido o excesso de turistas. Além disso, a construção de equipamentos turísticos causa a poluição visual, pois modifica a paisagem. A poluição do ar, da água e sonora são também fatores negativos causados por motores, produção, consumo de energia, falta de saneamento e a destruição da fauna e da flora.

Para que os impactos ambientais do turismo sejam prevenidos, é buscar um desenvolvimento sustentável não apenas do patrimônio natural, mas também dos produtos que se estruturam sobre os atrativos e equipamentos turísticos. Importante é examinar que um modelo de desenvolvimento sustentável do turismo deve considerar a gestão de todos os ambientes, os recursos e as 
comunidades receptoras a fim de atender às necessidades da população sem que ocorra a degradação do meio ambiente, ou seja, uma "exploração" consciente que não prejudique as gerações futuras.

Quando a atividade turística é explorada de forma desordenada, cria fatores desfavoráveis no ambiente socioeconômico e ecológico. Isso, por sua vez, tende a representar o comprometimento da própria existência do turismo. A integração da comunidade e as políticas que amenizem a imagem que uma má exploração pode causar são opções que podem ajudar a resolver essa situação.

Segundo a Associação Brasileira da Indústria Hoteleira de Santa Catarina (ABIH-SC), a crise da Argentina, os atentados terroristas em Nova York, em 2001, e a crise econômica brasileira de 2002 afetaram o turismo brasileiro e conseqüentemente, o do Estado de Santa Catarina e de seus municípios. Observase que o turismo rural, o de águas termais, o de aventuras, o religioso e o ecoturismo não sofrem tanta influência da sazonalidade como o turismo de praias.

Mas, existe uma procura maior pelo turismo de termas nos meses de inverno. No verão, a demanda depende do aspecto climático, ou seja, se o verão for chuvoso, os turistas que tinham como destino o litoral se voltam para o turismo termal e rural, entre outros. Como já foi dito, a crise econômica tanto nacional como nos países vizinhos ocasionou a diminuição da taxa de ocupação da rede hoteleira no ano de 2004, em relação ao ano de 2003.

\subsection{2 - Balneabilidade e Termalismo}

É um conjunto de atividades que envolvem a terapêutica pelas águas termo-minerais aplicadas a um doente durante a sua estadia numa Estância Termal (TEIXEIRA, 1990); outros que afirmam que o termalismo ou hidroclimatismo diz respeito ao conjunto de tratamento hidriático, climático, pelóidico, pepsâmico, cinésico, psicológico e higienodietético.

Todos eles, sempre que possível, empregados simultaneamente, constituem um programa com diversas modalidades de cura e admitindo-se, em determinados casos, a complementação com fisioterapia e farmacoterapia (MOURÃO, 1992). Empregamos aqui a designação termalismo quando nos 
referimos ao conjunto de atividades terapêuticas desenvolvido no espaço de um estabelecimento balneário e que tem como agente terapêutico a água termal.

A hidrologia desenvolveu-se durante o século XIX (WEISZ, 1995), nela se inscrevendo a hidrologia médica, que se refere ao tratamento médico feito por meio das águas em geral, apresentando três divisões: hidroterapia, crenoterapia e talossoterapia. (MOURÃO, 1997).

Georges Weiss, na análise que faz do papel da academia médica francesa no desenvolvimento do termalismo (water cures), afirma ter sido a elite médica francesa que, pelo desenvolvimento da hidrologia, permitiu o desenvolvimento do termalismo na França com indústria e medicina.

Os médicos brasileiros sofreram a influência das escolas médicas francesas e mimetizaram os processos de instauração da hidrologia médica no Brasil. No Brasil chegou a ser introduzida, no início do século XX, na Universidade de Medicina de Minas Gerais, a cadeira de hidrologia e climatologia; na Faculdade de Medicina do Rio de Janeiro, os conteúdos de crenoterapia eram ministrados no curso de terapêutica geral (LOPES, 1931).

O fato de a disciplina ser ministrada na academia parecia dar crédito ao uso das águas minerais como prática terapêutica assentado sobre um saber científico, e não empírico, que cabia aos médicos prescrever só o critério científico dos médicos é que poderá indicar com acerto aquela [estação de águas] que mais convém ao doente. (AZEVEDO, 1882).

As termas foram também abordadas por HEMBRY (1997), que faz a história social das termas inglesas, e ZAPATER (1994), que realizou um estudo sociológico sobre as termas espanholas de Penticosta, analisando-as na perspectiva de uma prática de ócio.

Recentemente MACKMAN (1998) estudou a freqüência das termas francesas no século XIX como uma primeira prática de férias da burguesia, para quem o lazer não era ócio, mas uma atividade pela qual essa classe se tornaria voluntariamente .paciente. Mackman afirma que existe uma cultura específica de estar nas termas francesas entre os últimos anos do Antigo Regime e o fim do século XIX. O autor analisa como as termas ajudaram a criar e refinar uma prática de lazer para a burguesia emergente francesa. 
No Brasil, MARRAS (2002) estuda o processo histórico e social de formação da estância termal de Poços de Caldas (MG), partindo das tensões existentes entre médicos e políticos em torno das águas virtuosas.

Tal como afirma Ramalho ORTIGÃO (1875) no seu guia intitulado "Banhos de caldas e águas minerais", a importância dessa forma de tratamento residia, sobretudo na introdução de uma mudança na vida cotidiana. Esta podia ser obtida pela viagem, considerada só por si um fator importante do tratamento, talvez até mesmo o primeiro momento esses são também os elementos que a definem.

CHERNOVIZ (1890), no "Dicionário de medicina popular", exalta a viagem e a distração associadas aos efeitos curativos das águas minerais termais. Os curistas eram pessoas que procuravam a cura ou o tratamento de doenças habitualmente crônicas, sendo as mais freqüentes os nervos, as doenças de pele, as bronquites e o reumatismo.

A representação da natureza como sanatório tem uma história social, sendo, sobretudo no século XIX que o termalismo introduziu a idéia de cura climática, para o qual o clima e a qualidade do ar eram prescritos como tratamento. (WALTER, 1991).

As termas eram apresentadas como estâncias climáticas, lugares por excelência da natureza. Desse modo, figurava-se a natureza como um elemento de continuidade na construção social das termas, quer se falasse da cura, da manutenção da saúde ou da recreação e do repouso. As termas ou estâncias termais eram recomendadas como um epítome da natureza salutar e foram assim difundidas, com maior ênfase na saúde ou na doença, de acordo com o discurso médico, os interesses turísticos ou os grupos a quem se dirigiam (FERREIRA 1994) e continuam a dirigir.

Em relação às análises sócio-econômicas, verificou-se que as regiões que apresentam as ocorrências termais e termo-minerais tem apresentando um desenvolvimento econômico e social maior que as regiões vizinhas, gerando receita em várias frentes distintas, tanto no que se refere à produção de água engarrafada, bebidas em geral, como também o turismo de Balneário termal. 
A geração de incrementos ocorre não apenas no comércio local como também no aspecto social, pois incentiva a vinda de pessoas de fora, fato este, que funciona como fator de integração social.

A área 01 apresenta um maior desenvolvimento por possuir uma história mais antiga em relação ao extrativismo das águas termais e termo-minerais, mas a área 02 tem se desenvolvido, em termos de tempo, muito mais rápido que a área 01, pois existe uma maior especulação e marketing envolvido, o que acelera o processo de desenvolvimento da região. 


\section{1 - CONCLUSÕES}

Analisando a história do conhecimento geológico e hidrogeológico em relação às ocorrências termais e termo-minerais do Estado de Santa Catarina, além de compara-los a novos dados, chegou-se a uma nova hipótese em relação à gênese dessas ocorrências.

As teorias envolvendo a gênese do termalismo na região centrosul da borda oriental do Estado de Santa Catarina, levavam em sua grande maioria a apenas uma parte da solução, descrevendo causas isoladas para as origens, sem levar em conta a história geológica pretérita.

Estudando estes modelos genéticos chegamos a um modelo de gênese associada, onde os vários modelos são interligados pela sua história geológica. Assim o modelo baseado em magmatismo recente do juro-cretáceo, considerado como a fonte principal de termalismo das águas catarinenses, passa a ser a conseqüência de um evento maior e mais antigo, sem o qual não haveria os mais novos e conseqüentemente, talvez não houvesse o termalismo que existe hoje.

Através de sucessivas reativações, que foram capazes de manter condutos profundos abertos ou parcialmente abertos, as águas meteóricas puderam misturar-se às águas juvenis e aquecerem até a temperatura superior a $36^{\circ} \mathrm{C}$, média da temperatura das águas de área estudada. Estes eventos termo-tectônicos podem ser comprovados por dezenas de pesquisas embasadas em dados geocronológicos e petrográficos recentes, tanto no Brasil como em países vizinhos que sofreram reflexos dessas reativações.

O que auxiliou no grande número de ocorrências naturais na região centro-sul da Borda oriental em relação a região Oeste do Estado de Santa Catarina, onde não existem ocorrências naturais, é o fato de que na região oeste existe um pacote muito espesso se sedimentos da bacia do Paraná, além de expressiva camada de rochas básicas decorrentes do grande derrame do mesozóico, em geral superior a 700 metros, chegando facilmente a 1.000 metros. Na região oeste as águas termais e termo-minerais explotadas tem o seu calor devido a condição de grau geotérmico oriundo da grande 
profundidade de onde são extraídas, em geral em poços com mais de 800 metros de profundidade.

Na região oriental do estado prevalecem rochas do Complexo Cristalino, não recobertas, facilitando o acesso das águas meteóricas nas câmaras magmáticas ativas.

Em estudos de fluxo geotérmico, feito em rochas das principais litologias do Estado de Santa Catarina, além de dados físico-químicos coletados ao longo de mais de 30 anos em análises de surgências e poços tubulares profundos, pode-se chegar a conclusão que existe uma região de termalismo anômalo em Santa Catarina, que está associado em parte as suítes intrusivas graníticas, principalmente a Pedras Grandes, onde ocorrem praticamente todas as ocorrências naturais do Estado de Santa Catarina.

As idades geológicas desta suíte são superiores a 500 milhões de anos, portanto o calor residual da intrusão granítica é atualmente desprezível, ou seja, não pode ser considerada como a fonte do termalismo.

Conclui-se, portanto que a ocorrência de fontes termais é indicativa da existência de calor residual de processos tectonotermais recentes, do período final do Mesozóico ao Cenozóico, que reativaram câmaras magmáticas dessas suítes, além de criarem novas câmaras.

Este magmatismo recente é dominado por rochas alcalinas que apesar de pouco expressivas em termo de extensão, possuem características genéticas contributivas para o hidrotermalismo em questão, e em menor escala a magmatismo básico com algumas ocorrências de diques com idade de cerca de 70 MA.

Pode-se citar como pertencentes a este magmatismo alcalino em Santa Catarina os corpos de Anitápolis, Quarenta e Lages, sendo que destes o de Anitápolis é o mais significativo para as ocorrências termais da Área 01.

Na região sul da área estudada não há ocorrência de rochas alcalinas em superfície, porém o mesmo evento que gerou as rochas alcalinas ao norte, gerou também grandes remobilizações de fluorita, um mineral tipicamente hidrotermal, formando grandes depósitos onde hoje é conhecido como Distrito Fluorítico de Santa Catarina. 
Essas fluoritas são responsáveis pelo grande teor desse elemento nas águas termais daquela região, resultando assim em águas fluoretadas, o que seria um dos mais fortes indícios de hidrotermalismo daquelas águas e minerais. 


\section{2- BIBLIOGRAFÍA}

ALBUQUERQUE, L.F.F. et alli 1971 - Geologia das Quadrículas de Blumenau e Joinville-SC.DNPM/CPRM,(inéd.),Porto Alegre.

ALMEIDA, F.F.M. 1948 - Contribuição à Geomorfologia da Região Oriental de Santa Catarina. Anais Associação de Geógrafos Brasileiros. São Paulo 2 (1): 10-38

ALMEIDA, F.F.M. 1986. Distribuição regional e relações tectônicas do magmatismo pós-paleozóico no Brasil. Revista Brasileira de Geociências, vol. 16, nº 4, p. $325-349$

AMÂNCIO, R. \& GOMES, M. A. O.2001 Ecoturismo e sustentabilidade. Curso de Pós-Graduação "Lato Sensu"- Ecoturismo: Interpretação e educação ambiental.Lavras: UFLA/FAEPE, 2001.

AMARAL, G.; CORDANI, V.G.; KAWASHITA, K.; REYNOLDS, J.H. 1967. Potassium-argon ages of alkaline rocks from southern Brasil. Geoch. Cosmoch. Acta, n. 31. p. 117-142.

AMIROU, R. 1995 - Imaginaire touristique et sociabilités du voyage. Paris,

ARAÚJO, R.L.C .1977 - Pesquisa de Fluxo térmico na chaminé alcalina de Poços de Caldas. Tese de Mestrado. Dpto. Geofísica, IAG - USP, São Paulo, 120 p.

ÁVILA,L.E; AWDZIEJ, J.; PARAHYBA, R.E.R.; BICCA, V.H.F. Águas Minerais de Santa Catarina, DNPM, $11^{\circ}$ distrito, 1986.

AWDZIEJ, J., PORCHER, C.A. e SILVA, L.C., 1986, Mapa geológico do Estado de Santa Catarina. Escala 1:500.000, Departamento Nacional de Produção Mineral - DNPM/MME e Secretaria de Indústria e Comércio do Estado de Santa Catarina.

AZEVEDO, A.1882 Das aguas mineraes em geral e especialmente do Brasil. Conferências Cezar de Miranda populares feitas nas Escolas da Glória e de São José no Rio de Janeiro em 1882, $2^{\mathrm{a}}$ ed., Campanha, Typographia Monitor Sul Mineiro. 
ATLAS DE SANTA CATARINA (Estado). Secretaria de Estado de Coordenação Geral e Planejamento. Subsecretaria de Estudos Geográficos e Estatísticos. $1991.96 \mathrm{p}$.

BASEI, M. A. S - 1985 - O Cinturão Dom Feliciano em Santa Catarina. São Paulo. USP. 185p.(Tese de Doutorado)

BENTO, A. 1841 - A agoa nos diferentes estados em que se acha na Natureza, e sobre as águas Luiz Ferreira potaveis em tratamentos. Descrição e analyse quimica das principais agoas do Rio de Janeiro. Dissertação de doutoramento em medicina, Rio de Janeiro, Faculdade de Medicina.

BIGARELLA,J.J.; SALAMUNI,R. (1961). Ocorrência de sedimentos continentais na região litorânea de Santa Catarina e sua significação paleoclimática. Boletim Paranaense de Geografia, 4/5, Curitiba, pp. 179 - 187.

BORGES, S.F. 1994. Avaliação Hidrogeológica do Manancial subterrâneo que abastece o Complexo Turístico Águas Mornas Palace Hotel - Município de Águas Mornas, SC, não Publicado.

BRITO NEVES, B.B - 1999 - América do Sul: quatro fusões, quatro fissões e o processo acrescionário Andino. Rev. Bras. Geociências, São Paulo. v. 29, n. 3, p. 379-392..

CARDOSO, R.R; GOMES, A.J.L; FREIRE, P.G; ABEID,L.R.F. 2004. Estudos Geotérmicos no Estado de Santa Catarina. OB- Observatório Nacional Relatório de Trabalho de Campo,24 p.

CARNEIRO, C.D.R. \& de ALMEIIDA, F.M. 1990. Vulcões do Brasil. Revista Ciência Hoje, vol. $11, n^{\circ} .62$, p. $28-36$.

CARRARO, C.C.; ISSLER, R. S.; FORMOSO, M.L.L. 1967. Mapeamento do distrito alcalino de Altos do Rio Pinheiros, Município de Anitápolis, Estado de Santa Catarina. Porto Alegre: Univ. Fed. Rio Grande do Sul, 45p. (Publ. Espec. n. 16).

CARVALHO, P.F. de \& PINTO, E.A. 1938 - Reconhecimento Geológico no Estado de Santa Catarina. Rio de Janeiro. DNPM. 30p. (Boletim da Divisão de Geologia e Mineralogia, 92)

CARVALHO, H. S. e VACQUIER, V. 1977 - Method for determining terrestrial heat ow in oil elds, Geophysics, 69:163\{188. 
CARVALHO, H.S.1981 - Método para determinação de fluxo geotérmico com aplicações nas bacias sedimentares petrolíferas do recôncavo Baiano (Brasil) e Sumatra (Indonésia), Tese de Doutorado. PPPG-UFBA, Salvador, 92p.

CASTRO,E.C. DE \& CASTRO,V.H.S. de 1969 - Geologia da quadrícula de Laguna, Santa Catarina, Brasil. DNPM, Porto Alegre, 38p. (Relat..Inéd.).

CASTRO, A. M. 1841 - As aguas mineraes brasileiras e em particular as do Rio de Janeiro. Tese de de Miranda medicina, Rio de Janeiro, Escola Médica do Rio de Janeiro.

CHERNOVIZ, L.1890 - Dicionário de medicina popular e das ciências acessórias para uso das famílias. Paris, A Roger \& Chernoviz, vol. I, $6^{\text {a }}$ ed.

COITINHO, J.B.L. 2000. Águas Minerais de Santa Catarina, Tese de mestrado, COBRAC 2000 . Congresso Brasileiro de Cadastro Técnico Multifinalitário . UFSC Florianópolis · Outubro 2000.

CORREA NETTO, O. 1917 - As águas thermaes brasileiras na prática da hydrologia médica. Poços de Caldas, Typografia Bernardes.

COX, A. \& R.B. HART, 1986 - Plate Tectonics - How it Works, Blackwell Scientific Publications, Palo Alto, California, USA.

CUSTÓDIO, E. \& LLAMAS,M.R. -1976 - Hidrologia Subterranea. Segunda Edicion.Ediciones Omega S.A. Barcelona,Espanha.

DAITX, E. C. - 1979 - Projeto Guaratubinha - Piên. Brasil. Conv. DNPM/CPRM. São Paulo, $184 \mathrm{p}$.

D'ELBOUX, C.V.; TAVARES, J.R.P.; PAIVA, I.B. 1982. Proposição de modelo mineralizador básico alcalino para pesquisa mineral na região meridional do escudo pré-cambriano brasileiro. In:CONGR. BRAS.GEOL., 32, Salvador, 1982. Anais. Salvador: SBG. v. 3,p.I061.1072.

DERBY,O. A; 1878. A Geologia da Região diamantífera da Provincia do Paraná. Arq. Mus. Nac. Rio de Janeiro. 3:89-98.

DERNER, A.L; 2004 - Tese - Novas modalidade turísticas no Minicípio de Santo Amaro da Imperatriz: Uma abordagem exploratória

DNPM - Banco de Dados - SISMINE. Brasília/DF

DNPM - Banco de Dados: SIGHIDRO e CADASTRO MINEIRO. Brasília/DF

DNPM Decreto . Lei no 7.841 . 8 de Agosto de 1945. Disponível na internet em 1945 www.dnpm.gov.br/d7841-45.html 
DNPM - Relatório final de pesquisa Processo 2.360/ 1942

DNPM - Relatório final de pesquisa Processo 809.746/1972;

DNPM - Relatório final de pesquisa Processo 815.153/ 2001

DNPM - Relatório final de pesquisa Processo 815.174/1991;

DNPM - Relatório final de pesquisa Processo 815.213/ 2002

DNPM - Relatório final de pesquisa Processo 815.372/ 1992;

DNPM - Relatório final de pesquisa Processo 815.374/ 1985;

DUTRA, E. B.1926. Reconhecimento Topográfico e geológico no Estado de Santa Catarina. Brasil - DNPM/SGM. Boletim n² 21, p.31-56.

DUTRA, A. T. B.1992. A banda de música e sua função na comunidade de Santo Amaro da Imperatriz. Florianópolis: [s.n.], 1992. 120 p.

EPAGRI / CLIMERH. Empresa de Pesquisa Agropecuária e Extensão Rural de Santa Catarina / Centro de Informações de Recursos Ambientais e de Hidrometeorologia. Secretaria de Estado da Organização. Diretoria de Planejamento e Desenvolvimento Turístico. Pesquisa Mercadológica estudo da demanda turística: município de Santo Amaro da Imperatriz: sinopse 2003 e 2004.[s.l.]; 2004.20 p.

FERREIRA, C. 1994 - Os usos sociais do termalismo: práticas, representações e identidades sociais dos freqüentadores das termas da Curia. Tese de mestrado, Coimbra, Faculdade de Economia de Coimbra.

FERREIRA, A. C.; ALMEIDA, T. I. R. 1989. Tectônica transcorrente e imagens TM-

LANDSAT aplicadas à prospecção de fluorita e barita em Santa Catarina. Revista Brasileira de Geociências, 19 (2): 207-223.

FONTES, L.C.A.A. 1980 - Determinação do Fluxo geotérmico na Bacia sedimentar Sergipe-Alagoas - Tese de mestrado. PPPG - UFBA, Salvador, 73 pp.

FOURNIER, R.O. 1973. Silica in thermal water: laboratory and field investigation. In: SYMP. HIDROGEOCHEM. BIOGEOCHEM. Tokio, 1973. Proceedings... Tokio, Clarke Company Tokio. v.I

GAPLAN, 1986. Atlas de Santa Catarina. Gabinete de Planejamento e Coordenação Geral, $173 p$

GEOCON geologia e Consultoria LTDA. Rua: Felipe Schmidt, n³90 - sala 710 Florianópolis - SC. Empresa de Consultoria geológica. 
GERBOD, P. 1983 - Loisirs et santé: les cures thermales en France (1850-1900).. Em Dagmart, Adeline Oisivité et loisirs dans les societés occidentales au XIX siècle. Colloque pluridisciplinaire, Amiens 19-20 Novembre. Amiens: Centre de Recherche d.Histoire Sociale de L.Université de Picardie, pp. 195-203.

GONSALVEZ, A. 1936 - Aguas mineraes do Brasil. Dinis et al. Ministério da Agricultura.

GORDON Jr.,M. 1947. Classification of the Gondwanic Rocks of Paraná, Santa Catarina, and Rio Grande do Sul. Notas Preliminares e Estudos, Divisão de Geologia e Mineralogia, 81: 1-19.

GUAZELLI, W. \& CARVALHO, J.C. 1981. Estrutura da margem continental leste brasileira e das áreas continentais e oceânicas adjacentes. In: Projeto REMAC. Aspectos estruturais da margem continental leste e sudeste do Brasil. Rio de Janeiro:

HAMZA,V.M. 1982 - Terrestrial heat flow in the alkaline intrusive complex of Poços de Caldas, Brazil. Tectono-physics, 83:45-62

HARIDASAN, M. 1994. Solos do Distrito Federal. p. 321-344. In: Novaes-Pinto, M. (ed.) Cerrado: Caracterização, ocupação e perspectivas - O caso do Distrito Federal. $2^{\mathrm{a}}$ ed. Editora Universidade de Brasília/SEMATEC, Brasília. 681 p.

HARTDANY, C.J.H., JOUBERT, P., STOWE, C. 1985 - Proterozoic Crustal Evolution of Southwestern Africa. Episodes, Ottawa, v. 8, p. 236-244.

HARTMANN,L.A; SILVA,L.C. \& ORLANDI FoV.; 1979 - O Complexo Granulítico de Santa Catarina: Descrição e Implicações Genéticas. Acta Geológica Leopoldensia, São Leopoldo. RS.

HEMBRY, P. 1997 - British spas from 1815 to the present: a social history. Londres, Athlone Press.

HORBACH,R. \& MARIMON,R.G. - 1982 - Contribuição à geologia do distrito de fluorita de Santa Catarina.BRASIL. Projeto RADAMBRASIL, Bol.Técn. n¹. Série Geologia. Salvador.104 p.

HURTER. J.S. 1987 - Aplicação de Geotermômetros químicos em águas de fontes brasileiras na determinação de fluxo geotérmico. Tese.

IVANOV, V.C. 1973 - Main genetic types and formation processes of thermae in volcanic and non-volcanic áreas. In SYMP. HIDROGEOCHEM. 
BIOGEOCHEM. Tokio, 1973. Proceedings...Tokio, Clarck Company Tokio. V. 1; pag. 174

JAQUES, I. A. Grupo Gravatal Hotéis de Turismo. Jornal Diário Catarinense, Florianópolis, agosto 1998. Caderno especial p. 2 -17.

JELINKE, A.R. 2003. A ocorrência de Gorceixita e de Inclusões sólidas de Halita em fluorita da Jazida de Nova Fátima: Implicações na Gênese da Mineralização do Distrito Fluorítico de Santa Catarina.

KAUL, P.F.T. (1976) - Projeto Brusque - Serra do Taboleiro. BRASIL. Convênio DNPM/CPRM, Porto Alegre, $165 \mathrm{p}$.

KAUL,P.F.T \& TEIXEIRA, W. 1982 - Archean and Early Proterozoic Complexes os Santa Catarina, Paraná and São Paulo States, South Eastern Brasil; an outline of their geologic evolution. Revista Brasileira de Geociências, 12.

KLEIN. R.M. 1978. Mapa fitogeográfico do estado de Santa Catarina. Itajaí, SUDESUL/FATMA/HBR. 24p., 1 mapa.

KUMAR, V.; BHATIA, B.K.; SHUKLA, V.C. Magnesium and zinc relationship in relation to dry matter yield and the concentration and uptake of nutrients in wheat. Soil Science, v.131, p.151-155, 1981.

LEINZ, V. - 1949 - Contribuição a Geologia dos Derrames do Sul do Brasil - Bol. $\mathrm{n}^{\circ}$ 103,Geol .5, Fac. Fil. Cienc. e Letras da USP, São Paulo.

LEMOS, P. 1930-1931 - As águas thermaes de Poccos de Caldas, MG, BH. Sanches de Lepierre, Charles .Chimie et physico-chimie des eaux. Le Portugal Hydrologique et Climatique (vol. I e II).

LINDGREN, W. 1933. Mineral Deposits, 4 ed.. New York, McGraw Hill, 930p.

LIMA, A.1888 - Relatório sobre as águas mineraes de Poços de Caldas, Lambary e Caxambu, apresentado ao Ministério do Império. Rio de Janeiro, Imprensa Nacional.

LOCZY, L. - 1964 - Problemas de Estratigrafia e Paleogeografia Carbonífera da Bacia do Paraná. Brasil. DGM/DNPM, Rio de Janeiro, Boletim(214), 113 p..

LOPES, R. 1947 - Breves notícias sobre a Geologia dos Estados do Paraná e Santa Catarina: Arq. Biol. Tecnol. Curitiba. 
MAACK, D. 1998 - Leisure settings. Bourgeois culture, medicine and the spa in modern France. Peter Chicago, Chicago University Press.

MACKMAN, D. 1998 - Leisure settings. Bourgeois culture, medicine and the spa in modern France. Peter Chicago, Chicago University Press.

MARRAS, S. 2002 - A propósito de águas virtuosas. Formação e ocorrências de uma estação balneária no Brasil. Dissertação de mestrado, São Paulo, Departamento de Antropologia Social, FFLCH, USP.

MARSH, J.S., 1973. Relationships between transform directions and alkaline rock lineaments in Africa and South América Earth Plan. Sci. Lett. №18, pg.317323.

MARTINS, C. 2001 - Tabuleiro das águas: resgate histórico e cultural de Santo Amaro da Imperatriz. Florianópolis: Ed. Recriar, 408 p.

MEISTER,E.M .1973 - Gradientes geotérmicos nas bacias sedimentares Brasileiras. Boletins Técnicos da Petrobrás, 16 (4).

MIRANDA,J.M.; LUIS, J.F; COSTA, P.T; SANTOS, F.M. 2005 - Manual de Fundamentos de Geofísica - Portugal.

MORETTO NETO, L.1993 - A atividade turística e o desenvolvimento sustentado: estudo de caso: o Balneário de Ingleses e o projeto Costa Norte. 677 p. Dissertação (mestrado em geografia) - Universidade Federal de Santa Catarina, Florianópolis.

MORGENTAL, A. \& KIRCHNER, C.A. - 1983a - Projeto Fluorita no Sudeste de Santa Catarina. Relatório Preliminar.Etapa 1 - mapa previsional. DNPM/CPRM. P.Alegre. (Relat. Inéd.).

MORGENTAL, A. \& KIRCHNER, C.A. - 1983b - Síntese do Mapa Previsional do Distrito de Fluorita de Santa Catarina. In: SIMPÓSIO SULBRASILEIRO DE GEOLOGIA, 1, Porto Alegre., 1983. Atlas do.....Soc. Bras. Geol. , p.294-301.

MOURÃO, B. 1997 - A água mineral e as termas: uma história milenar. São Paulo, Abinam.

MOURÃO, B. 1992 - Medicina hidrologica: moderna terapêutica das águas minerais e estâncias de cura, Poços de Caldas, Ed. Prisma.

MÜHLMANN, H., SCHNEIDER, R.L; TOMAS, E; MEDEIROS, R.A; DAEMON, R.F; NOGUEIRA, A.A - (1974). Revisão estratigráfica da Bacia do Paraná. 
Departamento Exploração e Produção. PETROBRÁS/DESUL, Relatório Interno. Ponta Grossa. 186 p.

MÜLLER, D., 1997 - , D., ROEST, W. R., ROYER, J.-Y., GAHAGAN, L. M., and SCLATER, J. G. (1997). Digital isochrons of the world's ocean floor. J. Geophys.

Res.,102:3211-3214.

phacite.es.su.oz.au/StaffProfiles/dietmar/Agegrid/agegrid.html.

NETO, C.O., 1917. As águas thermaes brasileiras na pratica hydrologia médica. Poços de Calcas. Typografia Bernardes

ORTIGÃO, R. 1875 - Banhos de caldas e águas minerais. Porto, Livraria Universal.

PETRI, S; FÚLVARO, V.J. Geologia do Brasil (Fanerozóico), São Paulo, T.A. QUEIROZ, Ed. Da Universidade de São Paulo - USP, 631 p.

PIMENTEL, M.M. , FUCK, R.A. Neoproterozoic crustal accretion in Central Brazil. Geology, Boulder, CO. v. 20, p. 375-379. 1992.

POLYAK, B. G., \& Ya. B. SMIRNOV, Relation between terrestrial heat flow and the tectonics of continents, Geotectonics, 205-213, 1968.

PUTZER,H. - 1953 - Diastrofismo "Germanótipo" e Sua Relação com o Vulcanismo Basáltico na Parte Meridional de Santa Catarina - Bol n¹,vol 2, Soc.Bras. de Geol., São Paulo.

PUTZER,H. - 1955 - Geologia da Folha de Tubarão,SC- DNPM/DFPM, Bol.n 96, Rio de Janeiro.

QUINTELA, M. M; 2004 - Saberes e práticas termais: uma perspectiva comparada em Portugal (Termas de S. Pedro do Sul) e no Brasil (Caldas da Imperatriz). História, Ciência e Saúde - Manguinhos, vol. 11 (suplemento) p. 239-60.

RANKANA, K. \& SAHA-MA T. G. 1968. Geochemistry (Geoquímica). University of Chicago

RENÉ, A.N.JR. 1992 - Monitoramento da cobertura vegetal em áreas litorâneas Anais VIII Simpósio Brasileiro de Sensoriamento Remoto, Salvador, Brasil, 14-19 abril 1996, INPE, p. 541-542

RENNER, J. L., WHITE, D. E., \& WILLIAMS, D. L., 1975, Hydrothermal convection systems, in White, D. E., and Williams, D. L., eds., Assessment of geothermal resources of the United States: U.S. Geological Survey Circular 726, p. 5-57. 
REVISTA TERMAS DO GRAVATAL, set de 2003.

RODRIGUES, B. 1974 - Tectonic alignments related with alkasline intrusions in Angola and Brazil Gondwana Symposiun Proc. P. 475-460.

RODRIGUES, M.. 1833 - Memória sobre as águas hydrosulfurosas, quentes ou não e sobre a água virtuosa ou acidula. Provincia de Minas Geraes, incluidos seus uzos médicos externos ou internos. Rio de Janeiro, Typographia do Diario de N. L. Vianna.

ROISENBERG, A. \& VIERO, A.P. 2000. O vulcanismo mesozóico da Bacia do Paraná no rio Grande do Sul. In: Holz, M. \& De Ros, L.F. (eds.), Geologia do Rio Grande do Sul, UFRGS-CIGO, p. 355 - 374.

ROGERS, J.J.W. History of Continents in the Past Three Billion Years. J. of Geology, Chicago, v.104, p. 91-107. 1996.

RUSCHMANN, D.V.M. Turismo e planejamento sustentável: a proteção do meio ambiente. Campinas, SP: Papirus, 1997,

SANTA CATARINA (Estado). Secretaria de Estado da Organização. Diretoria de Planejamento e Desenvolvimento Turístico. Pesquisa Mercadológica estudo da demanda turística: município de Santo Amaro da Imperatriz: sinopse 2003 e 2004.[s.I.]; 2004.20 p.

SANTA CATARINA. Secretaria de Estado de desenvolvimento regional. São José, Caracterização regional.[S.I.], 2003.42 p.

SANTO AMARO: indústria, comércio e turismo.Vitrine Popular, Santo Amaro da Imperatriz, 29 out. 2004.p, 3.

SANTOS, S. C. dos. Índios e brancos no sul do Brasil: a dramática experiência dos xokleng. Florianópolis: Lunardelli, 1973.

SANTOS, J. 1986 - Densidade de Fluxo Geotérmico na Bacia do Paraná - Estado de São Paulo - Tese.

SANTOS, J. N. dos.1994 - Santo Amaro da Imperatriz: "paraíso das águas". Florianópolis: Edeme, 1994.191 p.

SANTOS, M. Sociedade e espaço: a formação social como teoria e como método. In: Espaço e sociedade. Petrópolis: Vozes, 1982. p. 9-19. 
SANTOS, S. C. dos.1977 - Nova história de Santa Catarina. 2a ed. [S.I.]: S. C. dos Santos, $124 p$.

SAVI, C.N. 1980 - Gênese e Controle das mineralizações de Fluorita da Região de Criciúma - SC. Dissertação de Mestrado. UNB.

SCHULZ JR. , A. \& ALBUQUERQUE, L.F.F. (1969) - Geologia da Quadrícula de Rio do Sul, Santa Catarina. BRASIL. DNPM. Porto Alegre, 109 p.

SCHULZ JR.,A. \& ALBUQUERQUE,L.F.F \& RODRIGUEZ,C.S.de - 1970 - Geologia da Quadrícula de Florianópolis,SC. Brasil.DNPM, Porto Alegre, 75 p. (Relat.Inéd.).

SCHEIBE, L.F. 1978, O kimberlito "Janjão", Lajes, Santa Catarina, Brasil; nota preliminar. Florianópolis.UFSC. (PaineldePesquisasdaUFSCI)

SCHEIBE, L.F.;KAWASHITA, K.;GOMES, C. de B. 1985. Contribuição à geocronologia do complexo alcalino de Lajes, SC. In: SIMP. SUL-BRAS. GEOL., 2, Florianópolis, 1985. Anais... Florianópolis: SBG/NRS-CS-PR. p. 299-308.

SEBRAE. Diagnóstico do potencial turístico do município de Santo Amaro da imperatriz. Santo Amaro da Imperatriz, 1997,

SÉRIES HISTÓRICAS - EPAGRI \& CLIMERH, ANOS 1969 a 2004

SERZEDELO, J. 1884 - Guia de viagem para as águas minerais de Caxambu, Caldas, Lambary, Contendas e Cambuquira na Provincia de Minas Gerais contendo todas as informações daquelles lugares; das suas medicamentosas. Rio de Janeiro, Typ. Augusto dos Santos.

SILVA, A. L. 1994 - Turismo saúde. São Paulo, Senac.

SILVA,L.C. \& DIAS, A. A. - 1981 - Os segmentos meridiano e setentrional do Escudo Catarinense: II - Organização e Evolução Geotectônica. Acta Geologica Leopoldensia. São Leopoldo 5(10): 235 - 265.

SILVA, L. C. - 1982 - Projeto Mapas metalogenéticos e de previsão de recursos minerais - Folha SG.Z.D. (Florianópolis). Carta Metalogenética. DNPM/CPRM, Porto Alegre. Mapas. (Rel. Inéd.).

SILVA, L.C. (1987) - Textos Básicos de Geologia e Recursos Minerais de Santa Catarina $-E=1: 500.000$ - Florianópolis: $11^{\circ}$ Distrito do DNPM; Coordenadoria 
de Recursos Minerais da Secretaria de Ciência e Tecnologia, Minas e Energia.

SILVA, L.C \& BORTOLUZZI,C.A.1987 - Texto explicativo para o Mapa Geológico do Estado de Santa Catarina, escala 1:500.000. Florianópolis. DNPM/Secretaria Ciências Tecnológicas. Minas e Energia. 216p.

SILVA, M. A. S. 2000 - Programa Levantamentos Geológicos Básicos do Brasil. Criciúma, Folha SH.22-X-B. Estado de Santa Catarina. Escala 1:250.000. I Organizado por Marco Aurélio Schneiders da Silva e Sérgio Reali Leites. Brasília: CPRM, 2000.

SANTOS, S.C.dos; 1973 - Índios e Brancos no Sul do Brasil - A Dramática experiência dos Xokleng.

STEWART, T.J., Relationships between DEA e Multicriteria Decision Analysis, Journal of the Operational Research Society, v. 47, 1996, pp. 654-665.

TAILLEUX, P. 1991- Histoire des thermes de Forges-Les-Eaux.Luneray, Bertout.

TEIXEIRA, C.A.S. $1969^{a}$ - Relatório Preliminar de Geologia das Quadriculas de Braço do Norte e Morro da Fumaça, 1:50.000. Porto Alegre. DNPM. 37p.

TEIXEIRA, C.A.S. $1969^{\mathrm{b}}$ - Relatório de Estágio no Centro de Pesquisas Geocronológicas da Universidade de São Paulo. Porto Alegre. DNPM. 39p.

TEIXEIRA, F. 1990 - O termalismo no quadro das políticas de saúde e da segurança social ...Congresso da Federação Internacional do Termalismo e Climatismo,o - S. Pedro do Sul. Lisboa, Associação Nacional dos Industriais de Águas Minero-Medicinais e de Mesa, pp. 25-60.

THORTHWAITE, C. W; 1955 - The Water Balance Publications en Climatology, 8 (1), Canterton, New Jersey. 104 p.

TRAININI,D.R.et alli 1978- Projeto Vidal Ramos Biguaçú. BRASIL. Conv. DNPM/CPRM. Porto Alegre, 330 p. (Rel.Inéd.).

TROMPETTE,R. 1994 Geology of Western Gondwana 2.000-500 Ma. The PanAfrican Brasiliano Amalgamation of South America and Adjacent Africa. Rotterdam, Balkema. 366p.

TUBELIS, A.; NASCIMENTO, F. J. L. Meteorologia descritiva: fundamentos e aplicações brasileiras. São Paulo: Nobel, 1980. 374 p. 
TURNER, S.; REGELOUS, M.; KELLEY, S.; HAWKESWORTH, C.; MANTOVANI, M. 1994. Magmatism and continental break-up $m$ the South Atlantic: high precision 40Ar-39Ar geochronology. Earth Planet. Sci. Lett., 124:333-348.

UNRUG, R.1996 - The assembly of Gondwanaland. Episodes, Ottawa, v.19, p.1120.

UYEDA,S \& WATANABE,T. 1970 - Preliminary report of terrestrial heat flow study in the South American continent: Distribuition of geothermal gradients. Tectonophlsics, 10:235-242.

VELOSO, H.P. \& GÓES FILHO, L. 1982. Fitogeografia brasileira - classificação fisionômica-ecológica da vegetação neotropical. Salvador, Bol. Téc. Proj. RADAMBRASIL, série vegetação, n.1, p.1-80.

VENEZIANI, P.;ANJOS, C.E.dos.;1993 - Prospecção de água termomineral na região de Termas da Guarda (SC) com a utilização de técnicas de Sensoriamento Remoto. VII Simpósio de Sensoriamento Remoto, Curitiba, 10-14 Maio, 376-384,

VILLWOCK, J.A.; TOMAZELLI, L.J.; LOSS, E.L.; DENHARDT, E.A., HORN FILHO, N.O.; BACHI, F.A.; DENHARDT, B.A. Geology of the Rio Grande do Sul Province. In: ABASSA, J.; ed. International Symposium on sea çevel changes ande quaternary shorelines, São Paulo, 1986. Quaternary of South Ame ri ca and Antar tic Pe ninsula. Bal kema: Rot terdam, v. 4, p. 79-97, 1984.

WALLON, A. 1981 - La vie quotidienne dans les Villes D.Eaux (1850-1914).

WALTER, F. .La montagne des Suisses. Invention et usage d.une représentation paysagère..1991 Études Rurales, 121/124, pp. 91-107.

WEISS, G. 1995 - The medical mandarins: the French Academy of Medicine in the ninetennth and twuentieth centuries. Oxford, University Oxford Press, pp.13758.

WHITE, I. C. 1908. Relatório final da Comissão de Estudos das Minas de Carvão de Pedra do Brasil. Relatório sobre "coal measures" e rochas associadas do Sul do Brasil. Parte I, Geologia, 201 p. 
WHITE, D.E. 1970 Geochemistry applied to the discovery, evaluation and explotation of geothermal energy resources. Geothermics. Spec. Iss, 2 (1). 58-80

WILLIG,C.D. et alli 1972- Observações sobre os controles e a gênese dos depósitos de fluorita de Santa Catarina. Eng.Min. e Met., Rio de Janeiro, (343):36-41.

ZANINI, L.F.P; 1997 - Programa Levantamentos Geológicos Básicos do Brasil Florianópolis (Folha SG-22-Z-D-V) e Lagoa (SG-22-Z-D-VI). Estado de Santa Catarina. Brasília. CPRM. 252 p.

ZAPATER, O. .1994 - La clientela balneária de Panticosa (1826-1936). Sociología del Trabajo, 23, pp. 129-54.

Principais Sites consultados:

http://www.scotese.com

http://www.nasa.gov

http:// www.embrapa.br

http://www.ibge.gov.br

http://www.epagri.rct-sc.br

http://www.climerh.rct-sc.br/

http://www.ocean.cf.ac.uk

http://www.dnpm.gov.br

http://www.santur.sc.gov.br

http://www.guiacatarinense.com.br

http://www.mma.gov.br

http://aguasefontes.ubbihp.com.br

http://www.sc.gov.br

http://www2.northyorks.gov.uk

http://www.cprm.gov.br/

http://www.igidl.ul.pt

http://www.sul-sc.com.br

http://www.zone.com.br

http://www.ineti.pt/

http://www.hoteisdesantacatarina.com.br 
http://www.santur.sc.gov.br

http://www.abinam.com.br

http://www.ana.gov.br/

http://www.pdv.com/lexico/menes/geotermica.htm

http://www.bdclima.cnpm.embrapa.br

http://maps.google.com/

http://www.belasantacatarina.com.br

http://www.brasilchannel.com.br

http://w3.ualg.pt

http://www.cse.ufsc.br

http://www.h2ogeo.upc.es

http://siagas.cprm.gov.br

http://www.cnps.embrapa.br

http://www.ral.dnpm.gov.br/sismineweb/logon.asp 
ANEXOS 
ANEXO o1

INVENTÁRIO DAS FONTES TERMAIS E TERMO-

MINERAIS DE SANTA CATARINA 


\begin{tabular}{|c|c|c|c|c|c|c|c|c|c|c|c|c|c|c|c|c|}
\hline MUNICIPIO & UTM & NOME DA FONTE & $\begin{array}{c}\text { TIPO DE } \\
\text { OCORRÊNCIA }\end{array}$ & $\begin{array}{c}\text { VAZÃO } \\
\text { m3/h }\end{array}$ & $\operatorname{TEMP}^{\circ} \mathrm{C}$ & PH & $\begin{array}{c}\text { DUREZA } \\
\text { (CaCO3) } \\
\mathrm{mg} / \mathrm{l}\end{array}$ & $\mid \begin{array}{l}\text { RES, EVAP, } \\
\text { A } 180^{\circ} \quad \text { mg/l }\end{array}$ & $\begin{array}{c}\text { CLASSIF, } \\
\text { FISICO- } \\
\text { QUÍMICA }\end{array}$ & $\begin{array}{l}\text { GEOLOGIA E } \\
\text { HIDROGEOLOGIA }\end{array}$ & $\begin{array}{c}\text { SílICA } \\
\text { mg/l }\end{array}$ & $\begin{array}{c}\mathrm{TSiO}^{\mathrm{T}} \\
\mathrm{C}^{\circ}\end{array}$ & $\begin{array}{c}\text { RADIOAT, } \\
\text { Maches }\end{array}$ & $\begin{array}{c}\text { ÁREA DO } \\
\text { ESTUDO }\end{array}$ & $\begin{array}{l}\text { FONTE } \\
\text { DOS } \\
\text { DADOS }\end{array}$ & $\begin{array}{c}\text { ANO DE } \\
\text { MEDIÇÃo }\end{array}$ \\
\hline Águas Mornas & $\begin{array}{l}713785 \\
6934074\end{array}$ & Chuá 01(desativada) & Surgência & 1,8 & $40^{\circ}$ & 6,6 & 23,5 & 86 & $\mathbf{F}, \mathbf{R}, \mathbf{H}$ & \multirow{5}{*}{$\begin{array}{c}\text { Complexo Águas Mornas / Granito } \\
\text { Serra do Tabuleiro Provincia } \\
\text { Hidrogeológica do Escudo Oriental } \\
\text { Sudeste }\end{array}$} & 21,68 & SD & 19,3 & № 01 & 1 e 5 & $1983 / 1985$ \\
\hline Águas Mornas & $\begin{array}{l}713777 \\
6934013\end{array}$ & Chuá 02(desativada) & Surgência & 10 & $38^{\circ}$ & 6,7 & 24 & 96 & $\mathbf{F}, \mathbf{R}, \mathbf{H}$ & & 21,68 & SD & 23,50 & $\mathrm{~N}^{\mathrm{o}} 01$ & 1 e 5 & $1983 / 1985$ \\
\hline Águas Mornas & $\begin{array}{l}714389 \\
6934600 \\
\end{array}$ & Águas Mornas & Surgência & 7,8 & $37^{\circ}$ & 6 & 25,02 & 64 & $\mathbf{N}, \mathbf{R}, \mathbf{M}$ & & 26 & 20 & 6,89 & № 01 & 1 e 5 & $1983 / 1995$ \\
\hline Águas Mornas & $\begin{array}{l}714262 \\
6934543 \\
\end{array}$ & Platina & Poço & 35 & $38^{\circ}$ & 6,3 & 25,55 & 53 & $\mathbf{N}, \mathbf{R}, \mathbf{M}$ & & 24,8 & 20 & 4,2 & $\mathrm{~N}^{\circ} 01$ & 1 e 5 & 1983 / 1995 \\
\hline Águas Mornas & $\begin{array}{l}713779 \\
6934001\end{array}$ & Crystal & Poço & 44 & $41,6^{\circ}$ & 6 & 24 & 88 & $\mathbf{F}, \mathbf{R}, \mathbf{H}$ & & 16,86 & 20 & 15,4 & $\mathrm{~N}^{\mathrm{o}} 01$ & $1 \mathrm{e} 2$ & 2003 \\
\hline $\begin{array}{c}\text { Santo Amaro da } \\
\text { Imperatriz }\end{array}$ & $\begin{array}{l}715772 \\
6930480\end{array}$ & Figueira & Surgência & 7,7 & $38,5^{\circ}$ & 6,8 & 20,09 & 75 & $\mathbf{F}, \mathbf{L}, \mathbf{R}, \mathbf{M}$ & \multirow{6}{*}{$\begin{array}{c}\text { Complexo Águas Mornas / Granito } \\
\text { Serra do Tabuleiro Provincia } \\
\text { Hidrogeológica do Escudo Oriental } \\
\text { Sudeste }\end{array}$} & 30,42 & SD & 32,18 & № 01 & $1 \mathrm{e} 2$ & $1997 / 2001$ \\
\hline $\begin{array}{c}\text { Santo Amaro da } \\
\text { Imperatriz }\end{array}$ & $\begin{array}{l}715785 \\
6930455 \\
\end{array}$ & Piscina & Surgência & 1,6 & $38,2^{\circ}$ & 7,2 & 25,1 & 84 & $\mathbf{F , L , R , M}$ & & 32,83 & 20 & 35,87 & $\mathrm{~N}^{\circ} 01$ & $1 \mathrm{e} 2$ & 1997/2001 \\
\hline $\begin{array}{c}\text { Santo Amaro da } \\
\text { Imperatriz }\end{array}$ & $\begin{array}{l}715791 \\
6930462 \\
\end{array}$ & Caldas I & Surgência & 20 & $39,8^{\circ}$ & 6,5 & 29,03 & 88 & $\mathbf{F , L , R , M}$ & & 28,8 & 20 & 32,87 & $\mathrm{~N}^{\mathrm{o}} 01$ & 1 & 2001 \\
\hline $\begin{array}{c}\text { Santo Amaro da } \\
\text { Imperatriz } \\
\end{array}$ & $\begin{array}{l}715797 \\
6930484 \\
\end{array}$ & Caldas II & Surgência & 20 & $39,8^{\circ}$ & 6,5 & 29,03 & 88 & $\mathbf{F , L , R , M}$ & & 28,8 & 20 & 32,87 & $\mathrm{~N}^{\circ} 01$ & 1 & 2001 \\
\hline $\begin{array}{c}\text { Santo Amaro da } \\
\text { Imperatriz } \\
\end{array}$ & $\begin{array}{l}715797 \\
6930484 \\
\end{array}$ & Nova & Surgência & 6,8 & $41^{\circ}$ & 7,1 & 27 & 125 & $\mathbf{F , L , R , M}$ & & 29,4 & SD & 46,37 & $\mathrm{~N}^{\mathrm{o}} 01$ & 1 & SD \\
\hline $\begin{array}{l}\text { Santo Amaro da } \\
\text { Imperatriz }\end{array}$ & $\begin{array}{c}711200 \\
3932300\end{array}$ & Baden-Baden & Poço & 60 & $37^{\circ}$ & 6,3 & 25,42 & 97 & $\mathbf{F}, \mathbf{L}, \mathbf{R}, \mathbf{M}$ & & $\mathrm{S}$ & SD & 28,45 & $\mathrm{~N}^{\circ} 01$ & 1 & SD \\
\hline Palhoça & $\begin{array}{l}728571 \\
6933669\end{array}$ & Jacob Vilain Filho & Poço & 15 & $37^{\circ}$ & 7,11 & 15,63 & 45 & $\mathbf{F , L , f , R , M}$ & \multirow{2}{*}{\begin{tabular}{|c|} 
Dep, Flúvio-lagunares / Riolito \\
Cambirella Provincia \\
$\begin{array}{c}\text { Hidrogeológica do Escudo Oriental } \\
\text { Sudeste }\end{array}$ \\
\end{tabular}} & 16,62 & SD & 7,29 & $\mathrm{~N}^{\mathrm{o}} 01$ & 1 e 5 & $1983 / 2003$ \\
\hline Palhoça & $\begin{array}{l}728563 \\
6933452 \\
\end{array}$ & $\begin{array}{c}\text { Santa Catarina de } \\
\text { Alexandria } \\
\end{array}$ & Poço & 35 & 36 & 5,94 & 14,5 & 75 & $\mathbf{F , L , f , R , M}$ & & 15,77 & SD & 9,4 & $\mathrm{~N}^{\mathrm{o}} 01$ & 1 e 5 & $1983 / 2003$ \\
\hline São Bonifácio & $\begin{array}{c}692312 \\
6899250 \\
\end{array}$ & São Bonifácio 01 & Surgência & 12 & $27,2^{\circ}$ & 5,8 & 12,18 & 40,4 & SD & Granito São Bonifácio & SD & SD & 41,89 & $\mathrm{~N}^{\mathrm{o}} 02$ & 1 & SD \\
\hline São Bonifácio & SD & São Bonifácio 02 & Surgência & 11 & $28,5^{\circ}$ & 5,7 & 14,48 & 38,6 & SD & Granito São Bonifácio & $\mathrm{SD}$ & $\mathrm{SD}$ & 34,3 & $\mathrm{~N}^{0} 02$ & 1 & $\mathrm{SD}$ \\
\hline São Bonifácio & SD & São Bonifácio 03 & Surgência & 110 & $26,1^{\circ}$ & 5,6 & 13,55 & 42,1 & SD & Granito São Bonifácio & $\mathrm{SD}$ & SD & 29,79 & $\mathrm{~N}^{\mathrm{o}} 02$ & 1 & SD \\
\hline Santa Rosa de Lima & $\begin{array}{c}686660 \\
6898570\end{array}$ & Sta Rosa de Lima 01 & Poço & 2,5 & 25,4 & 6,06 & 14,91 & 51 & $\mathbf{F}, \mathbf{R}, \mathbf{h}$ & \multirow{2}{*}{$\begin{array}{c}\text { Rocha granitóide do Batólito de } \\
\text { Pelotas Provincia Hidrogeológica } \\
\text { do Paraná }\end{array}$} & SD & SD & 44,51 & $\mathrm{~N}^{\circ} 02$ & 1 & SD \\
\hline Santa Rosa de Lima & SD & Sta Rosa de Lima 02 & Poço & 15 & 35,1 & 7,27 & 17,71 & 53 & $\mathbf{F}, \mathbf{R}, \mathbf{M}$ & & SD & SD & 29,2 & $\mathrm{~N}^{\mathrm{o}} 02$ & 1 & SD \\
\hline Armazém & $\begin{array}{r}694546 \\
6871651\end{array}$ & Santa Terezinha & Surgência & 21,24 & $35,8^{\circ}$ & 6,45 & 23,51 & 72 & $\mathbf{f}, \mathbf{R}, \mathbf{M}$ & \begin{tabular}{|c|} 
S,I, Pedras Grandes Provincia \\
Hidrogeológica do Paraná e Escudo \\
Oriental Sudeste
\end{tabular} & 41 & SD & 6,02 & $\mathrm{~N}^{\mathrm{o}} 02$ & 1 e 5 & 1983 \\
\hline Gravatal & $\begin{array}{l}691484 \\
6884632 \\
\end{array}$ & Fonte Tiradentes & Surgência & SD & $37,5^{\circ}$ & SD & SD & SD & SD & \multirow{2}{*}{\begin{tabular}{|c|} 
S,I, Pedras Grandes Provincia \\
Hidrogeológica do Paraná e Escudo \\
Oriental Sudeste
\end{tabular}} & SD & 20 & 18,20 & $\mathrm{~N}^{\mathrm{o}} 02$ & 5 & 1983 \\
\hline Gravatal & $\begin{array}{r}690167 \\
6865364 \\
\end{array}$ & Helio Agostinelli & Surgência & 144 & $36^{\circ}$ & 6,4 & 23,34 & 61 & $\mathbf{F}, \mathbf{R}, \mathbf{I}$ & & SD & 20 & 19,17 & $\mathrm{~N}^{\mathrm{o}} 02$ & 1 e 5 & 1983/ 1986 \\
\hline Imaruí & $\begin{array}{l}713431 \\
6861803 \\
\end{array}$ & Mineralli 01 & Surgência & 20 & $27,9^{\circ}$ & 5,74 & 7,81 & 53 & $\mathbf{F , R , h}$ & \multirow{2}{*}{\begin{tabular}{|c|} 
S,I, Pedras Grandes Provincia \\
Hidrogeológica do Paraná e Escudo \\
Oriental Sudeste
\end{tabular}} & 34 & SD & 31,38 & $\mathrm{~N}^{\mathrm{o}} 02$ & 1 e 5 & 1983 \\
\hline Imaruí & $\begin{array}{l}713442 \\
6882879\end{array}$ & Mineralli 02 & Poço & 20 & $28^{\circ}$ & 5,76 & 8,21 & 50 & $\mathbf{F , R , h}$ & & 38 & SD & 34,25 & $\mathrm{~N}^{\mathrm{o}} 02$ & 1 e 5 & 1983 \\
\hline
\end{tabular}




\begin{tabular}{|c|c|c|c|c|c|c|c|c|c|c|c|c|c|c|c|c|}
\hline Pedras Grandes & SD & Águas de São Pedro & Poço & 54 & $32,2^{\circ}$ & 7,4 & 11 & SD & $\mathbf{A}, \mathbf{B}, \mathbf{S}, \mathbf{F}, \mathbf{R}$ & \multirow{3}{*}{$\begin{array}{c}\text { S,I, Pedras Grandes Provincia } \\
\text { Hidrogeológica do Paraná e Escudo } \\
\text { Oriental Sudeste }\end{array}$} & SD & SD & 18,6 & $\mathrm{~N}^{\circ} 02$ & 5 & 1983 \\
\hline Pedras Grandes & SD & São Pedro & Surgência & 54 & $32,2^{\circ}$ & 7,9 & 10 & SD & $\mathbf{A}, \mathbf{B}, \mathbf{S}, \mathbf{F}, \mathbf{R}$ & & SD & SD & 9,83 & $\mathrm{~N}^{\mathrm{o}} 02$ & 5 & 1983 \\
\hline Pedras Grandes & SD & Santo Antônio & Surgência & 0,72 & $29,4^{\circ}$ & 7,6 & 10 & SD & $\mathbf{A}, \mathbf{B}, \mathbf{S}, \mathbf{F}, \mathbf{R}$ & & $\mathrm{SD}$ & SD & 18,20 & № 02 & 5 & 1983 \\
\hline Tubarão & $\begin{array}{c}685797 \\
6853392\end{array}$ & Santo Anjo da Guarda & Surgência & 22,5 & $37,8^{\circ}$ & 6,9 & 20,2 & 52 & $\mathbf{F , F F , R , I}$ & \multirow{3}{*}{$\begin{array}{c}\text { Granitóide Santo Antonio Provincia } \\
\text { Hidrogeológica do Paraná e Escudo } \\
\text { Oriental Sudeste }\end{array}$} & 26,2 & 19 & $\mathbf{5 0 , 5 2}$ & $\mathrm{N}^{\circ} 02$ & $1.3 \mathrm{e} 5$ & 1983 \\
\hline Tubarão & SD & Tenente & Surgência & SD & $36,8^{\circ}$ & $\mathrm{SD}$ & SD & SD & SD & & $\mathrm{SD}$ & SD & 18,20 & $\mathrm{~N}^{\circ} 02$ & 5 & 1983 \\
\hline Tubarão & SD & Balneário & Surgência & SD & SD & SD & SD & SD & SD & & $\mathrm{SD}$ & SD & SD & SD & 1 & 1997 \\
\hline Tubarão & $\begin{array}{c}682814 \\
6853364\end{array}$ & Guarda 01 & Surgência & 21 & $37,8^{\circ}$ & 6,09 & 17,7 & 52 & F,FF.R,I & \multirow{3}{*}{$\begin{array}{c}\text { Suite Plutono-Vulcânica Cambirela } \\
\text { Granito Rio Chicão Provincia } \\
\text { Hidrogeológica do Paraná e Escudo } \\
\text { Oriental Sudeste }\end{array}$} & 12,4 & SD & 50,52 & $\mathrm{~N}^{\circ} 02$ & 1 & 1997 \\
\hline Tubarão & SD & Guarda 02 & Surgência & 5,5 & $36^{\circ}$ & 6,01 & 13,2 & 51 & $\mathbf{F , R , I}$ & & SD & SD & 35,48 & $\mathrm{~N}^{\circ} 02$ & 1 & 1997 \\
\hline Tubarão & SD & Guarda 03 & Surgência & 6 & $38,4^{\circ}$ & 5,75 & 16,04 & 58 & $\mathbf{F}, \mathbf{R}, \mathbf{H}$ & & $\mathrm{SD}$ & SD & 46,12 & № 02 & 1 & 1997 \\
\hline Tubarão & $\begin{array}{c}686502 \\
6853392\end{array}$ & Rio do Pouso & Poço & 34,5 & $37^{\circ}$ & 6,99 & 41,08 & 111 & $\mathbf{O}, \mathbf{R}, \mathbf{I}$ & $\begin{array}{c}\text { Granitóide Santo Antonio Provincia } \\
\text { Hidrogeológica do Paraná e Escudo } \\
\text { Oriental Sudeste }\end{array}$ & 25,5 & 20 & 15,56 & $\mathrm{~N}^{\circ} 02$ & 3 & SD \\
\hline
\end{tabular}

LEGENDA

\begin{tabular}{|c|c|c|c|}
\hline \multicolumn{2}{|c|}{$\overline{\text { TEMPERATURA }}$} & \multicolumn{2}{|r|}{ CLASSIFICAÇÃO FISSICO-QUIMMICA DAS ÁGUAS TERMAIS E TERMO-MINERAIS } \\
\hline CLASSIFICAÇÃO & TEMP, & SIGLA & \\
\hline HIIPOTERMAIS & $25^{\circ}-33^{\circ}$ & $\mathbf{F , H}$ & FLUORETADA HIPERTERMAL \\
\hline MESOTERMAIS & $33^{\circ}-36^{\circ}$ & $\mathbf{F , R , I}$ & $\begin{array}{l}\text { FLUORETADA RADIOATIVA ISOTERMAL } \\
\end{array}$ \\
\hline ISOTERMAIS & $36^{\circ}-38^{\circ}$ & $\mathrm{F}, \mathrm{R}, \mathrm{H}$ & FLUORETADA RADIOATIVA HIPERTERMAL \\
\hline \multirow[t]{7}{*}{ HIPERTERMAIS } & $<\mathbf{3 8}^{\circ}$ & $\mathbf{F , R , h}$ & FLUORETADA RADIOATIVA HIPOTERMAL \\
\hline & & $\frac{1, R, M}{f, R, M}$ & FRACAMENTE RADIOATIVA MESOTERMAL \\
\hline & & $\mathbf{O , R , I}$ & OLIGOMINERAL RADIOATIVA ISOTERMAL \\
\hline & & $\mathbf{N}, \mathbf{R}, \mathbf{M}$ & NATURAL RADIOATIVA MESOTERMAL \\
\hline & & $\mathbf{A}, \mathbf{B}, \mathbf{S}, \mathbf{F}, \mathbf{R}$ & ALCALINO-BICARBONATADA SÓDICA FRACAMENTE RADIOATIVA \\
\hline & & $\mathbf{F , L , R , M}$ & FLUORETADA LITINADA RADIOATIVA MESOTERMAL \\
\hline & & $\mathbf{F , F F , R , I}$ & FLUORETADA FORTEMENTE RADIOATIVA ISOTERMAL \\
\hline
\end{tabular}

RADIOATIVIDADE CLASSIFICACÃO Radioativas

Fortemente Radioat

1 - CPRM / LAMIN - LABORATORIO DE ANALISES MINERAIS

2- GEOCON GEOLOGIA E CONSULTORIA LTDA
3-ON / MCT - OBSERVATÓRIO NACIONAL - RELATÓRIO DE ESTUDOS GEOTÉRMICOS NO ESTADO DE SANTA CATARINA (CARDOSO et all, 2004)

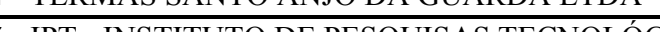

- IPT - INSTITUTO DE PESQUISAS TECNOLÓGICAS

SD - SEM DADOS 


\section{ANEXO o2}

\section{MAPA DE LOCALIZAÇÃO DA}

ÁREA ESTUDADA EM

RELAÇÃO A AMÉRICA DO

SUL, BRASIL E SANTA

\section{CATARINA}




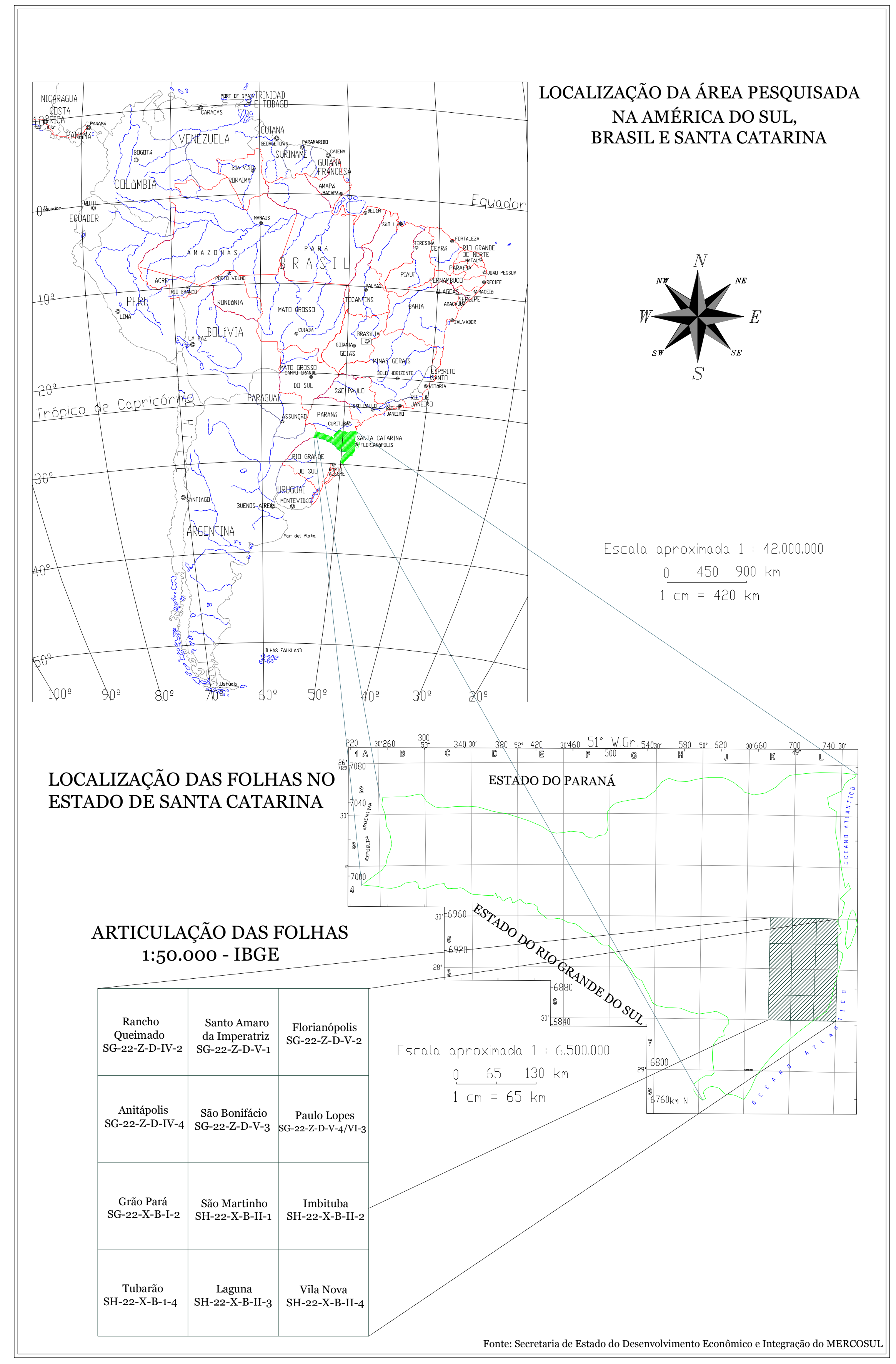


ANEXO o3

LOCALIZAÇÃO DAS REGIÕES

DE INTERESSE NO MOSAICO

DE CARTAS DO IBGE 


\section{LOCALIZAÇÃO DAS REGIÕES DE INTERESSE NO MOSAICO DE CARTAS DO IBGE}

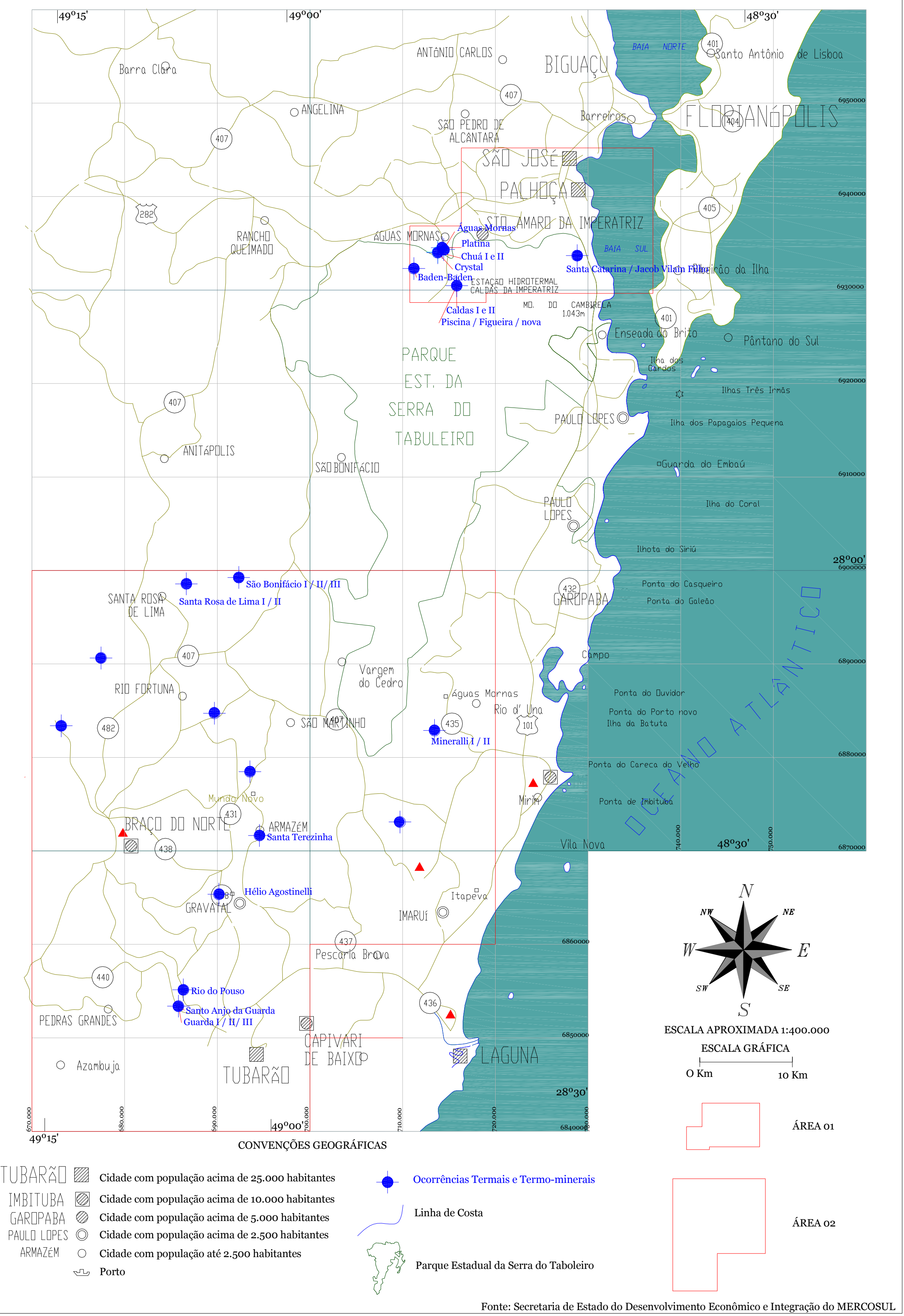


ANEXO O4

MAPA GEOLÓGICO REGIONAL DA ÁREA DE ESTUDO 


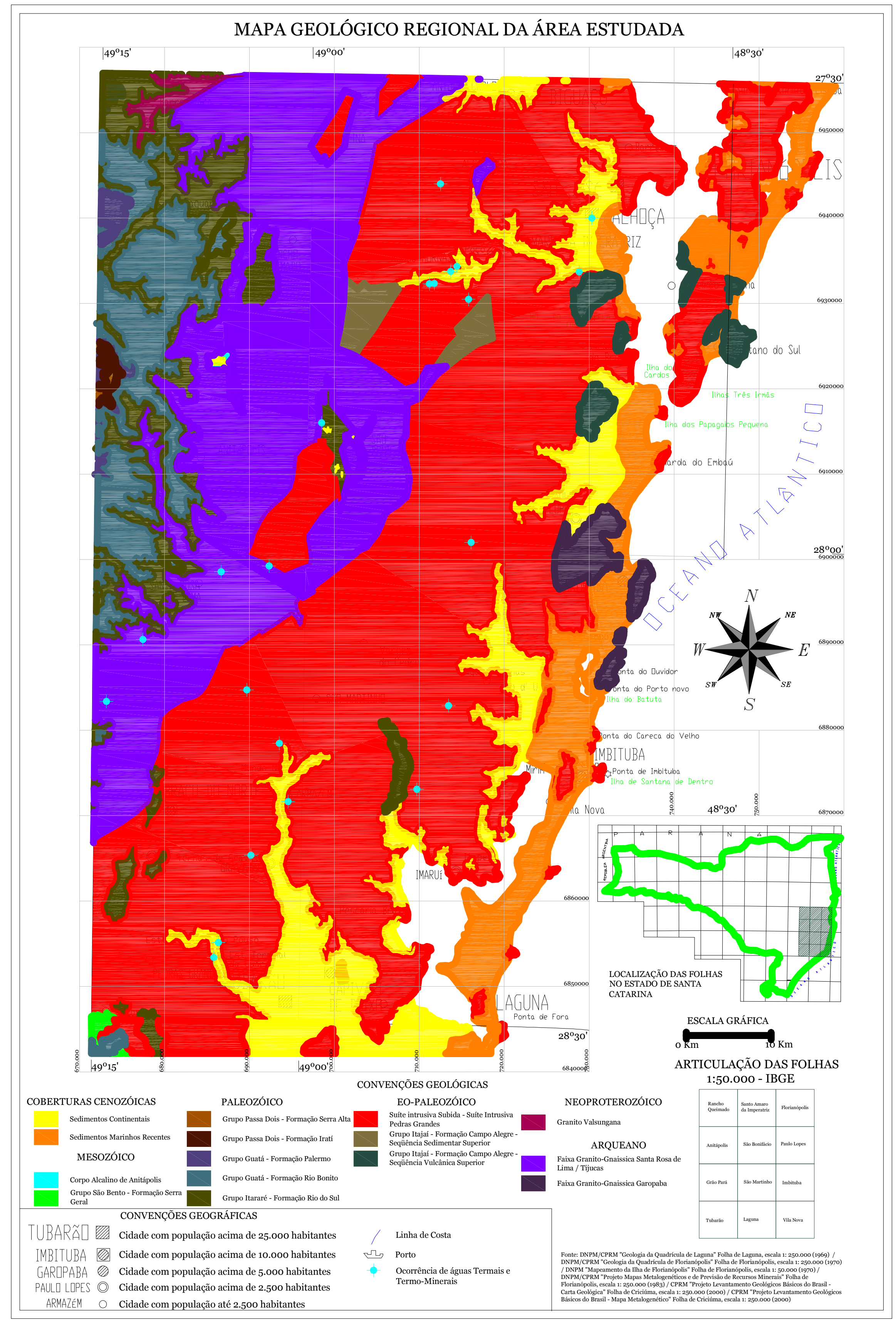




\section{ANEXO 05}

\section{MAPA DE LINEAMENTOS ESTRUTURAIS DA ÁREA DE ESTUDO}




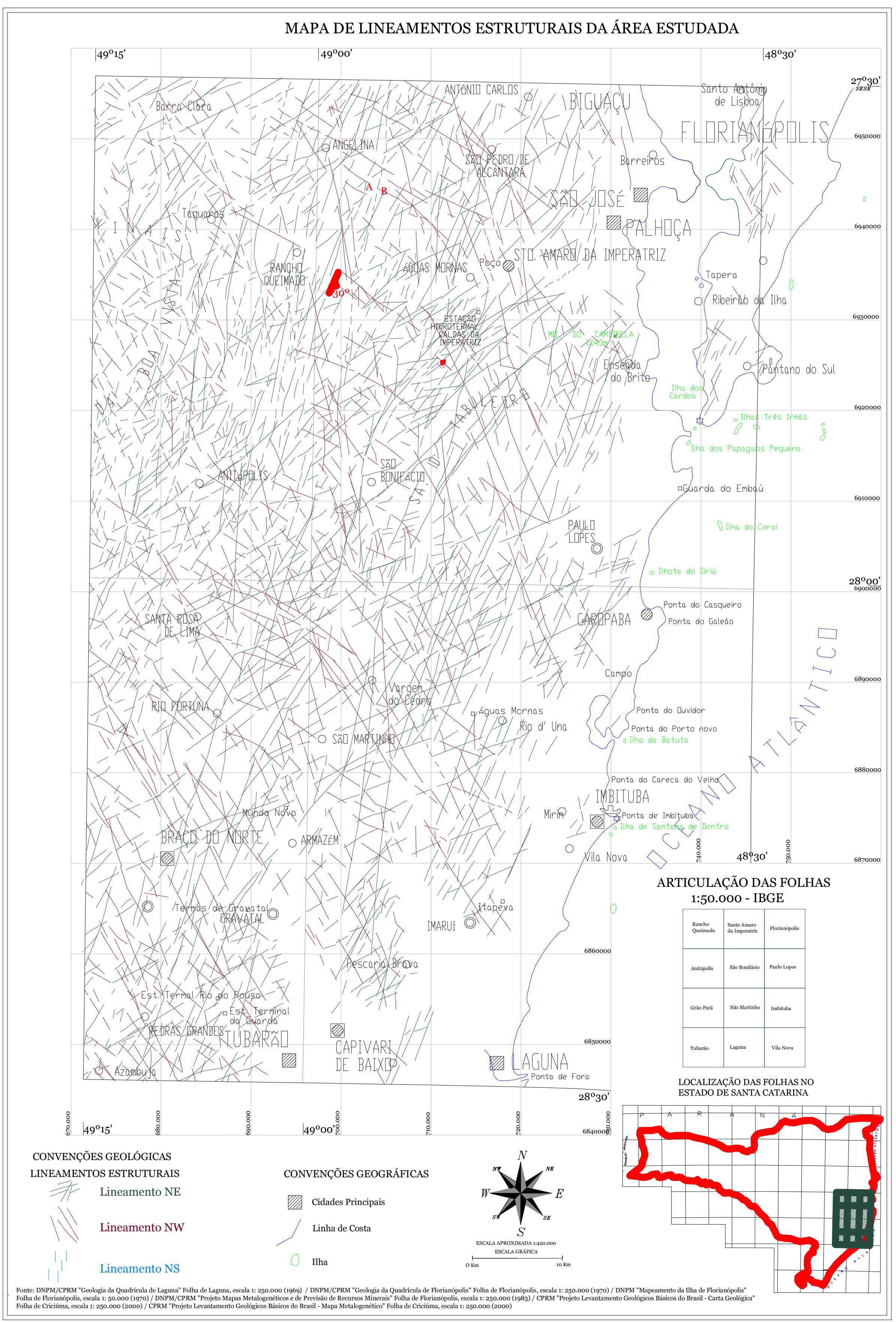


ANEXO o6

MAPA GEOLÓGICO DA

REGIÃO 01 


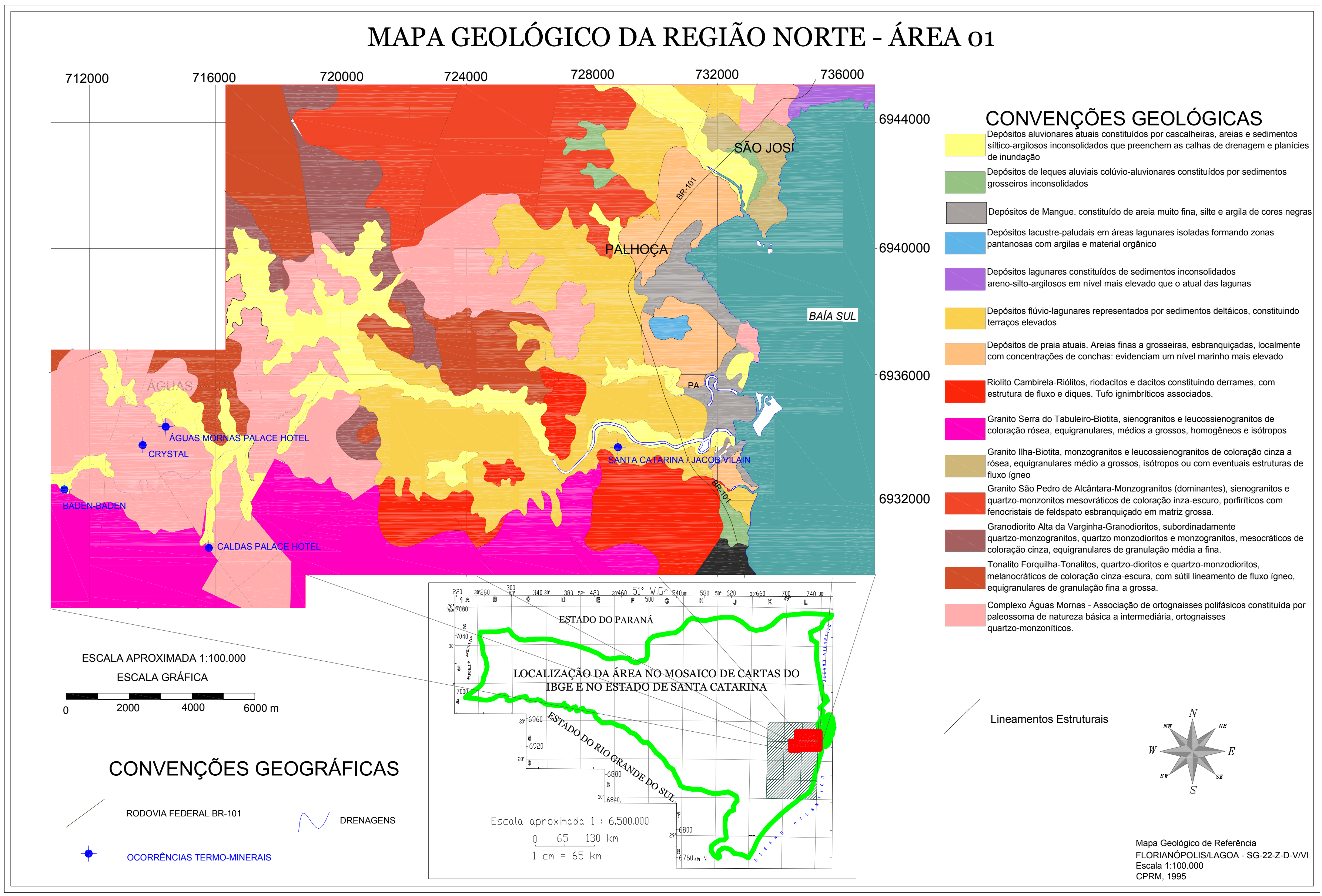


ANEXO o7

MAPA GEOLÓGICO DA

REGIÃO o2 


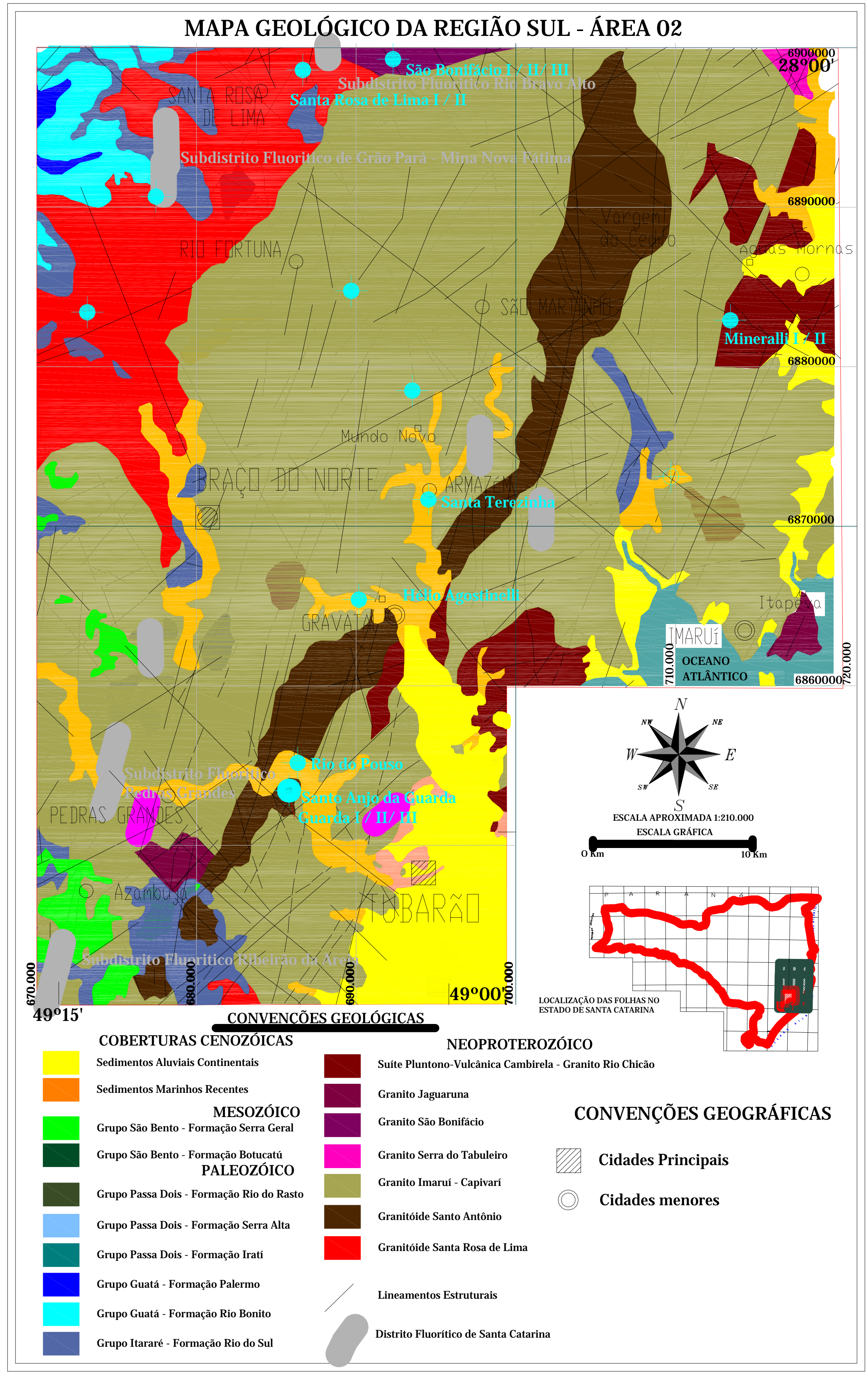


ANEXO o8

\section{MODELO DIGITAL DE TERRENO 3D DA ÁREA} ESTUDADA 
A visualização simultânea de dados fisiográficos e geológicos sobre um modelo digital de terreno constituem uma poderosa ferramenta para a análise e representação de dados em investigações geológicas e morfológicas. Estes modelos representam os resultados obtidos a partir da construção de um modelo tridimensional de 10 Folhas e escala 1:50.000 da região centro-oriental do Estado de Santa Catarina, onde são representados simultaneamente aspectos geológicos, litoestratigráfico, fisiográficos (padrão de relevo e drenagem) e Geográficos (uso e ocupação do solo) da região. Foram utilizadas ferramentas de computação gráfica para micromputadores utilizando os programas Surfer 8.0, Autocad 2005 e ferramentas de conversão e ajuste.

Acompanhando o desenvolvimento de modelos geométricos tridimensionais nas pesquisas em Geociências, apresentam-se os resultados obtidos a partir da construção de um Modelo Digital de Terreno (MDT) da região centro-oriental de Santa Catarina com a sobreposição de dados geográficos e geológicos, utilizando ferramentas da computação gráfica tridimensional em microcomputadores.

A visualização simultânea de dados topográficos e geológicos como entidades tridimensionais facilita a sua análise integrada nas investigações básicas geológicas e geomorfológicas bem como em projetos de pesquisa aplicados nos estudos de planejamento ambiental e urbano.

Os dados para a construção do modelo foram obtidos através da digitalização de curvas planialtimétricas, e dados geológicos, das seguintes Folhas:

> Folha Topográfica 1:50.000 - Florianópolis (SG-22-Z-D-V-2 )

> Folha Topográfica 1:50.000 - Santo Amaro da Imperatriz (SG-22-Z-D-V-1)

> Folha Topográfica 1:50.000 - São Bonifácio (SG-22-Z-D-V-3)

> Folha Topográfica 1:50.000 - Paulo Lopes (SG-22-Z-D-V-4/VI-3)

> Folha Topográfica 1:50.000 - São Martinho (SH-22-X-B-II-1)

> Folha Topográfica 1:50.000 - Imbituba (SH-22-X-B-II-2)

> Folha Topográfica 1:50.000 - Vila Nova (SH-22-X-B-II-4)

$>$ Folha Topográfica 1:50.000 - Laguna (SH-22-X-B-II-3) 
Folha Topográfica 1:50.000 - Tubarão (SH-22-X-B-I-4)

> Folha Topográfica 1:50.000 - Grão Pará (SH-22-X-B-I-2)

Para o processamento dos dados foram utilizados diferentes programas em ambiente Windows, tais como AutoCAD 2005 (Autodesk Inc.), Surfer 8.0 (Golden Software), além das rotinas de conversões DXF2TXT (Wateloo Inc.).

O aumento da performance dos microcomputadores praticamente quintuplicou nos últimos 10 anos e as capacidades dos programas atuais tem permitido alcançar um nível cada vez maior e melhor de detalhamento dos resultados obtidos.

Os procedimentos utilizados para a construção do Modelo Digital de Terreno (MDT) semi-realístico com sobreposição de mapas temáticos como o mapa geológico apresentado, descritos a seguir, consistem na apresentação desses mapas como ferramentas para estudos diversos, entre eles a hidrogeologia.

Das 10 Folhas Topográficas digitalizadas, onde as cotas variam entre 0 a 1200 metros, foram digitalizados mais de 200.000 pontos correspondentes à reprodução de todas as curvas de nível (7800 polylines), de 100 em 100 metros (Figura 1), o que apesar da grande distância entre curvas, garantiu uma boa resolução final.

Para evitar efeitos artificiais como tabuleiros ou vales chatos criados pela interpolação, procedeu-se a digitalização, além das curvas de nível, de pontos avulsos, especialmente em planícies, nos cumes acima da última curva de nível, bem como ao longo das drenagens (cotas estimadas entre duas curvas de nível). Também foi importante a digitalização de pontos intermediários nas bordas e nos cantos do mapa. Para a área que não faria parte do trabalho, foi determinado que as curvas de nível teriam valor 0 para que na hora da interpolação as curvas não sofressem um efeito de dobras redobradas pela tentativa do programa de interpolar diferentes cotas em um mesmo espaço. O arquivo inicial foi então exportado no formato DXF, pois o formato DWG não é reconhecido pelos programas que fazem a modelagem. 
Para a criação de um arquivo de dados tipo X,Y,Z (.DAT). Através da execução do programa DXF2DAT.EXE, efetuou-se a conversão do arquivo *.DXF contendo apenas as curvas e os pontos digitalizados com suas respectivas altitudes em um arquivo de dados no formato $X, Y, Z$ (.TXT).

Em todos os processos de conversões de arquivos, através da rotina "DXF2DAT.EXE”, pode-se evitar eventuais problemas certificando-se da sintaxe correta exigida por cada rotina (caminho e extensão). As grafias são distintas e específicas para cada rotina.

Para a geração de uma malha de dados regularmente espaçada (grid), os dados altimétricos irregularmente espaçados foram interpolados com o programa Surfer 8.0 utilizando-se o método de Krigagem.

O espaçamento do grid, fator determinante para o grau de detalhamento do modelo topográfico o que corresponde a uma malha de 100 linhas x 70 colunas, suficiente para uma análise regional.

As coordenadas dos limites do grid foram cuidadosamente definidas de acordo com as quatro extremidades da folha (Xmin, Xmax, Ymin, Ymax) como descrito abaixo:

Size: $\quad 100$ linhas $\times 70$ colunas

$\begin{array}{llll}\text { X Min: } & 671302 & \text { X Max: } & 748552 \\ \text { Y Min: } & 6845570 & \text { Y Max: } & 6956920 \\ \text { Z Min: } & -74.6344500055 & \text { Z Max: } & 1214.68169842\end{array}$

Para permitir um ajuste preciso na posterior sobreposição das imagens bidimensionais a malha gerada em ambiente Surfer foi salva em um arquivo tipo .GRD, no formato ASCII (x, y, z).

Para a construção da superfície topográfica como uma entidade tridimensional em ambiente AutoCAD, foi utilizada a rotina em Autolisp "Surfmesh.LSP". A rotina armazenada no diretório do AutoCAD é carregada na linha de comando do AutoCAD através do comando (load "surfmesh"). Quando executada, a rotina questiona o nome do arquivo de entrada e automaticamente 
desenha na tela o modelo em forma de malha retangular vazada ("wireframe" ou modelo de arame). Após o processamento das linhas e colunas, estas são inicialmente dispostas segundo os parâmetros originais do AutoCAD, de forma que o modelo é visualizado de cima (sobre o plano $X Y$ ) e não se observa a sua topografia. Com as opções VIEWPOINT/PRESETS o modelo pode ser visualizado de qualquer ângulo no espaço, preferencialmente a partir de uma visada lateral em ângulo inclinado.

O modelo, como uma entidade tridimensional, foi exportado em um arquivo no formato.DXF, através do comando DXFOUT.

Os elementos sobrepostos ao Modelo Digital de Terreno, tais como contatos geológicos das unidades litoestratigráficas das Folhas Geológicas da região, pontos de ocorrência de fontes termais e termo-minerais, contornos urbanos, estradas e lineamentos estruturais, foram digitalizados em ambiente AutoCAD em seus respectivos layers com o comando POLYLINE.

Os limites dos mapas utilizados na confecção das imagens 2D coincidem precisamente com os limites definidos anteriormente para a malha topográfica, a fim de evitar distorções na sua sobreposição ao MDT.

Depois de certificado que os contornos de cada unidade litoestratigráfica, ou unidades mapeadas encontravam-se perfeitamente fechados, necessário para o posterior hachureamento, os desenhos foram exportados como arquivos em formato *.DXF. Nesta fase a organização em diferentes layers foi fundamental para a seleção e combinação das entidades que irão compor as imagens 2D.

Os mapas produzidos foram hachurados utilizando-se o próprio AutoCAD para preencher os modelos com cores sólidas que tornam-se melhores para este tipo de modelo.

Para que o AutoCAD reconheça a figura a ser hachurada e realize o comando ela deve constituir uma poligonal fechada, quaisquer nós que não estejam fechados acusará erro e não será permitido o preenchimento da hachura.

O processamento do modelo tridimensional renderizado, através de processos de iluminação, sombreamento, foi efetuado em ambiente Surfer. 
O arquivo DXF importado pelo programa Surfer através do arquivo. TXT é lançado no programa na forma de tabela de dados e corvertido em GRID pelo Surfer.

O GRID resultante será jogado no programa em suas coordenadas originais já previamente calculadas no ambiente AutoCAD. O modelo, ainda em modo wireframe, teve a área entre cada polígono (da malha vazada) preenchida como uma superfície cheia, a partir da aplicação do comando "Surface".

Com o modelo orientado na posição desejada, iniciou-se o processo de iluminação através dos comandos da opção "Lights", cujas diferentes opções subdividem-se em "Ambient", "Omni” e "Spot”. A superfície 3D pode ser manejada no espaço (rotação, translação) e iluminada de diversas direções, gerando diferentes resultados de sombreamento que realçam as estruturas de relevo.

Por fim, as imagens bidimensionais salvas em arquivos raster no formato .JPG ou .DXF representando o mapa geológico, solos, estradas, fotolineamentos, limites urbanos ou quaisquer elementos que desejem ser representados. A aplicação destas imagens ao MDT já devidamente posicionado e iluminado, é feita através do comando "Map", "Ovelay Map", na seção de edição.

A renderização final do modelo, ou seja, o acabamento semirealístico, é feita pelo comando " 3 d surface" com várias opções como cor de fundo e resolução da imagem.

As melhores imagens geradas foram então salvas, cada uma em dois arquivos raster, também no formato Surfer GRID ou Surfer PLOT: uma com fundo preto para fotografia e outra com fundo branco para posterior impressão em relatórios, posters e publicações.

Modelos tridimensionais com resoluções maiores $(1280 \times 1024$ pixels) proporcionam melhor nitidez nas imagens, necessária por exemplo quando são representados os lineamentos estruturais sobrepostos à topografia e formações geológicas da área, ou quando se deseja obter visadas mais próximas de uma determinada área do modelo.

A partir do aprimoramento das técnicas para a construção de modelos digitais de terreno em microcomputadores foram gerados produtos de resolução e acabamento satisfatórios. A considerável melhoria nas capacidades de 
visualização e interpretação das feições morfológicas características dos lineamentos, como cursos d'água retilíneos, segmentos alinhados de vales e morfografia, associadas à distribuição das formações geológicas, classificação de solos e seus usos permitem o melhor reconhecimento das estruturas neotectônicas que controlaram a evolução geológica e fisiográfica da área e de sua compartimentação geomorfológica.

A comparação entre os resultados distintos de sombreamento para a análise do relevo, geologia e classificação do uso dos solos, iluminados de vários sentidos, mostram as vantagens do processamento de MDTs através de técnicas de computação gráfica tridimensional.

Além da melhor interpretação dos fenômenos geológicos e geomofológicos e do reconhecimento de feições morfoestruturais, os mapas tridimensionais constituem importante instrumento adicional às ferramentas de SIG e de fotointerpretação nas atividades de planejamento ambiental e de uso do solo. Através da visualização semi-realística e simultânea de relevo, substrato geológico e elementos antrópicos, pode-se determinar melhor áreas mais adequadas para diferentes atividades produtivas ou de preservação, como zonas de proteção ambiental (mananciais, várzeas, encostas, matas), industriais, de habitação, aterro sanitário, aeroporto, agricultura e mineração. A divulgação e localização de sítios históricos ou turísticos também pode ser substancialmente beneficiado por estas técnicas. 
ANEXO 09

GRÁFICOS COMPARATIVOS ENTRE AS FONTES

\section{ESTUDADAS}



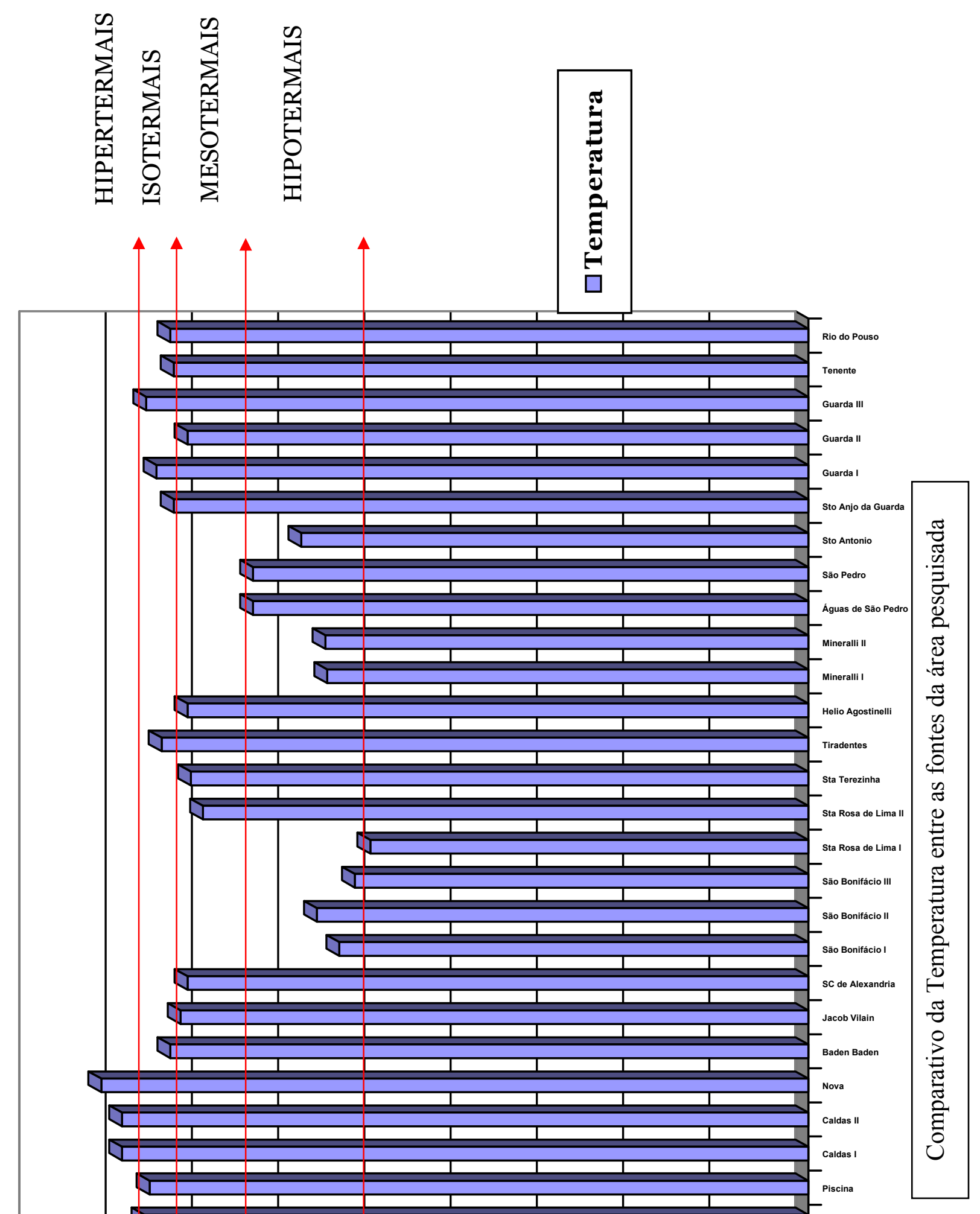


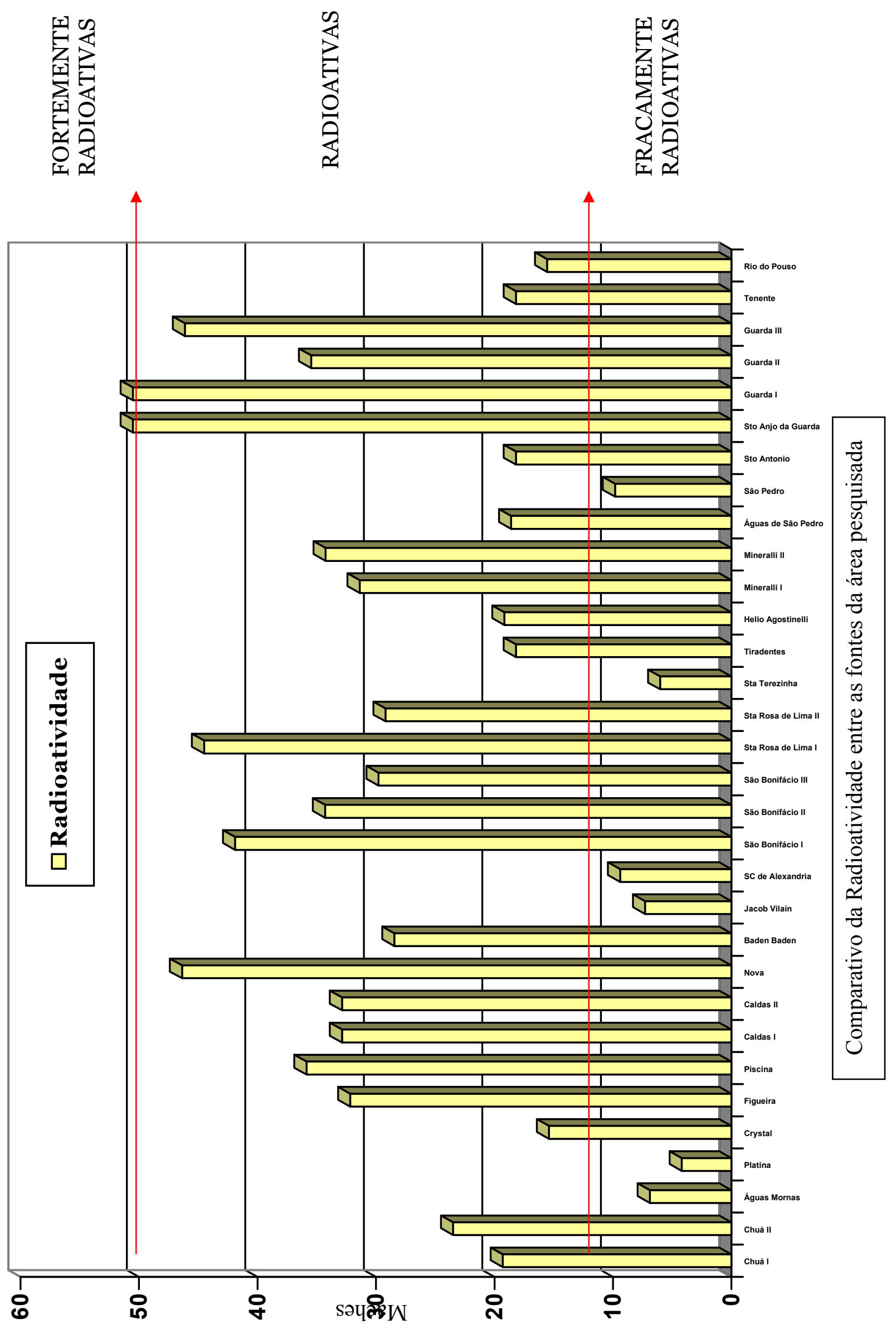




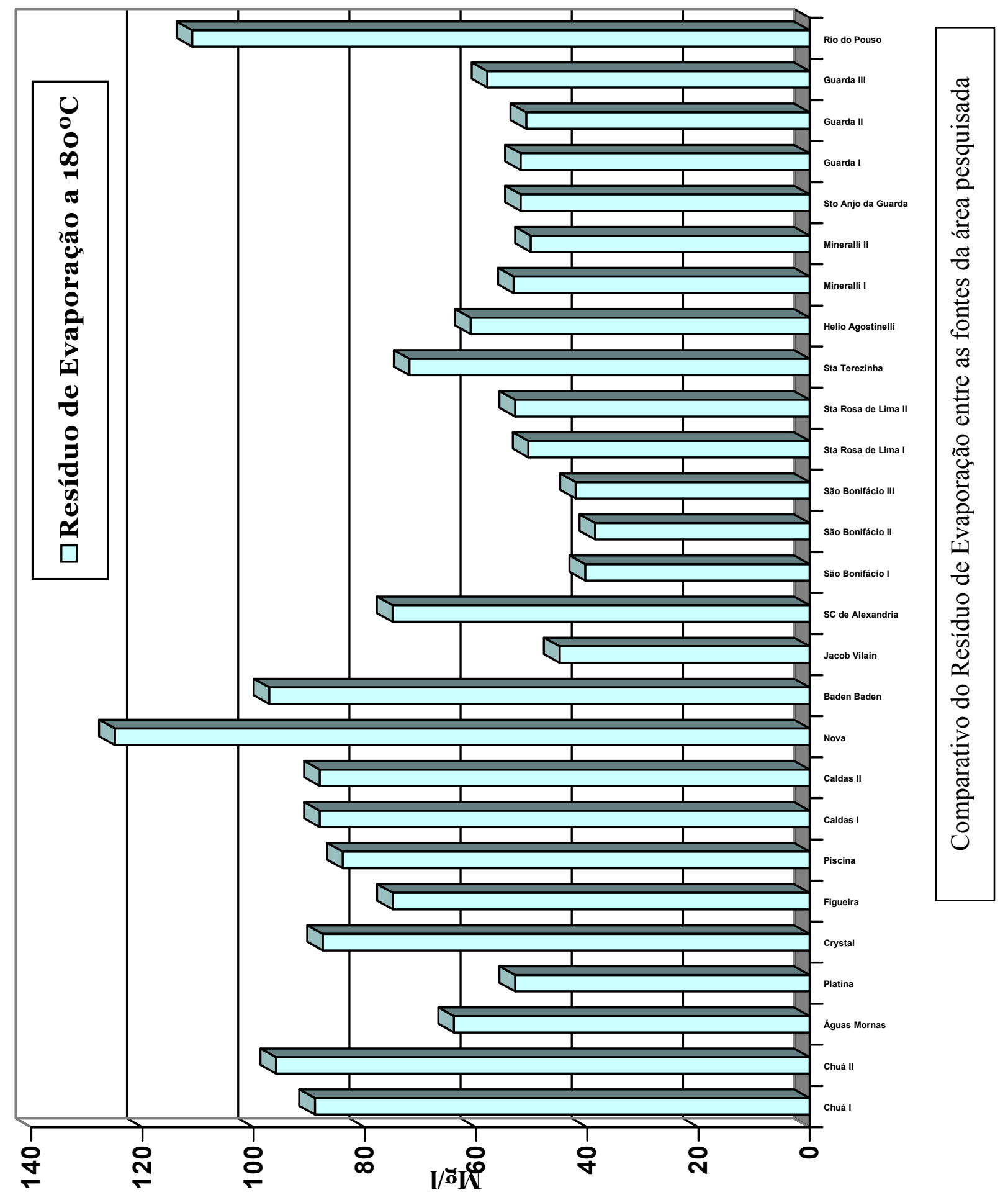


ANEXO 10

\section{SÉRIES HISTÓRICAS} CLIMÁTICAS 


\section{ESTAÇÃO METEOROLÓGICA DE FLORIANÓPOLIS}

LATITUDE: 27.35'

LONGITUDE: $48.34^{\prime}$

ALTITUDE: 1.84

METROS

\section{DADOS NORMAIS}

\begin{tabular}{|c|c|c|c|c|c|c|c|c|c|c|c|c|c|}
\hline MESES & $\begin{array}{l}\text { TEMP. } \\
\text { MEDIA } \\
\text { 'C }\end{array}$ & $\begin{array}{l}\text { TEMP. } \\
\text { Mx Abs } \\
\text { 'C }\end{array}$ & $\begin{array}{l}\text { TEMP. } \\
\text { Mn Abs } \\
\text { 'C }\end{array}$ & $\begin{array}{l}\text { MEDIA } \\
\text { TEMP MX } \\
\text { 'C }\end{array}$ & $\begin{array}{l}\text { MEDIA } \\
\text { TEMP } \\
\text { 'C) }\end{array}$ & $\begin{array}{l}\text { A PREC. } \\
\text { MnTOTAL } \\
(\mathrm{mm})\end{array}$ & $\begin{array}{c}\text { PR } \\
\text { em }\end{array}$ & $\begin{array}{l}\text { REC.MX } \\
24 \mathrm{~h} \\
(\mathrm{~mm})\end{array}$ & $\begin{array}{l}\text { DIAS DE } \\
\text { CHUVA } \\
\text { (No.) }\end{array}$ & $\begin{array}{l}\text { UMIDADE } \\
\text { RELAT } \\
(\%)\end{array}$ & $\begin{array}{c}\text { EVAPOR. } \\
\text { TOTAL Tan } \\
\text { Piche }\end{array}$ & $\begin{array}{l}\text { APOR. } \\
\text { de A } \\
(\mathrm{mm})\end{array}$ & $\mathrm{ETP}$ \\
\hline JAN. & 24.4 & 38.2 & 10 & 28.1 & 21.6 & 192.6 & & 55.4 & 16.6 & 81.2 & 102.4 & $\mathrm{~N}$ & $\mathrm{~N}$ \\
\hline FEV . & 24.6 & 38.8 & 14.8 & 28.4 & 21.7 & 186.7 & & 59.6 & 16.2 & 81.9 & 92.3 & A & A \\
\hline MAR. & 24 & 36.9 & 10.2 & 27.8 & 21.1 & 169.3 & & 52.9 & 15.6 & 82 & 95.3 & o & O \\
\hline ABR. & 21.8 & 33.3 & 7.7 & 25.6 & 18.8 & 128.2 & & 40.3 & 12.7 & 81.9 & 87.5 & & \\
\hline MAI. & 19.4 & 33.5 & 3.3 & 23.4 & 16.4 & 106.3 & & 46.9 & 10.1 & 82.4 & 77 & & \\
\hline JUN. & 17.1 & 32 & 1.7 & 21.4 & 14.3 & 85.1 & & 30 & 9.8 & 83.3 & 67.6 & E & E \\
\hline JUL. & 16.3 & 32.7 & 1.4 & 20.4 & 13.3 & 81.6 & & 30.3 & 10.2 & 83.5 & 70 & $\mathrm{x}$ & $\mathrm{x}$ \\
\hline AGO. & 16.8 & 33.5 & 1.3 & 20.7 & 13.9 & 93.1 & & 32 & 10.3 & 83.1 & 76.9 & I & I \\
\hline SET. & 17.8 & 32.9 & 4.9 & 21.2 & 15.1 & 116.1 & & 37.4 & 13.1 & 83.1 & 79.2 & S & S \\
\hline OUT. & 19.4 & 32.5 & 7.8 & 22.6 & 16.7 & 132.4 & & 38.9 & 14.3 & 81.8 & 93.3 & $\mathrm{~T}$ & $\mathrm{~T}$ \\
\hline NOV. & 21.2 & 34.8 & 9.4 & 24.5 & 18.3 & 132.3 & & 47.4 & 14.3 & 80.1 & 101.7 & $\mathrm{E}$ & $\mathrm{E}$ \\
\hline DEZ. & 23 & 38.2 & 12.5 & 26.5 & 20.1 & 138.7 & & 45.7 & 14.8 & 80.1 & 111.8 & & \\
\hline
\end{tabular}

ANOS

OBS. $\begin{array}{rllll}84 & 68 & 67 & 84 & 85\end{array}$

MESES NEBULOS. INSOL. RAD.SOLAR PRESSAO VELOC VELOC. DIRECAO DOS VENTOS GEADAS HORAS GLOBAL ATMOSF. DO VENTO DO VENTO $1 \mathrm{a}$ DE FRIO
$(0 / 10) \quad($ horas $) \quad(\mathrm{cal} / \mathrm{cm} 2$
$(\mathrm{mb}) \quad(\mathrm{m} / \mathrm{s}) \quad(\mathrm{km} / \mathrm{h})$
(dias) $\left(<7.2^{\prime} \mathrm{C}\right)$

\begin{tabular}{|c|c|c|c|c|c|c|c|c|c|c|}
\hline JAN. & 6.8 & 187.6 & $\mathrm{~N}$ & 1009.7 & 3.5 & 12.6 & $\mathrm{~N}$ & $\mathrm{NE}$ & 0 & $\mathrm{~N}$ \\
\hline FEV. & 6.7 & 173.6 & A & 1010.4 & 3.6 & 12.96 & $\mathrm{~N}$ & S & 0 & A \\
\hline MAR. & 6.3 & 185 & 0 & 1011.7 & 3.4 & 12.24 & $\mathrm{~N}$ & $\mathrm{SE}$ & 0 & o \\
\hline $\mathrm{ABR}$. & 5.9 & 174.7 & & 1013.1 & 3.2 & 11.52 & $\mathrm{~N}$ & $\mathrm{SE}$ & 0 & \\
\hline MAI. & 5.5 & 177.2 & & 1015.3 & 2.9 & 10.44 & $\mathrm{~N}$ & S & 0 & \\
\hline JUN. & 5.5 & 156.8 & $\mathrm{E}$ & 1016.3 & 3 & 10.8 & $\mathrm{~N}$ & S & .1 & $\mathrm{E}$ \\
\hline JUL. & 5.5 & 166.1 & $\mathrm{X}$ & 1017.9 & 3.1 & 11.16 & $\mathrm{~N}$ & $\mathrm{NE}$ & 0 & $\mathrm{x}$ \\
\hline AGO. & 6 & 159.8 & I & 1017.2 & 3.6 & 12.96 & $\mathrm{~N}$ & $\mathrm{NE}$ & .1 & I \\
\hline SET. & 7 & 130.3 & S & 1015.9 & 3.8 & 13.68 & $\mathrm{~N}$ & S & 0 & S \\
\hline OUT. & 7.1 & 147.3 & $\mathrm{~T}$ & 1014.1 & 4.1 & 14.76 & $\mathrm{~N}$ & $\mathrm{NE}$ & 0 & $\mathrm{~T}$ \\
\hline NOV. & 6.8 & 172.2 & $\mathrm{E}$ & 1011.6 & 4.2 & 15.12 & $\mathrm{~N}$ & $\mathrm{NE}$ & 0 & $\mathrm{E}$ \\
\hline DEZ. & 6.8 & 188.4 & & 1009.9 & 4 & 14.4 & $\mathrm{~N}$ & $\mathrm{NE}$ & 0 & \\
\hline
\end{tabular}

Série histórica da estação Meteorológica de Florianópolis 
ESTACAO METEOROLOGICA DE URUSSANGA

ABERTURA: 01/01/1924

LATITUDE: $28.31^{\prime}$

LONGITUDE: 49.19'

ALTITUDE: 48.17

metros

\section{DADOS NORMAIS}

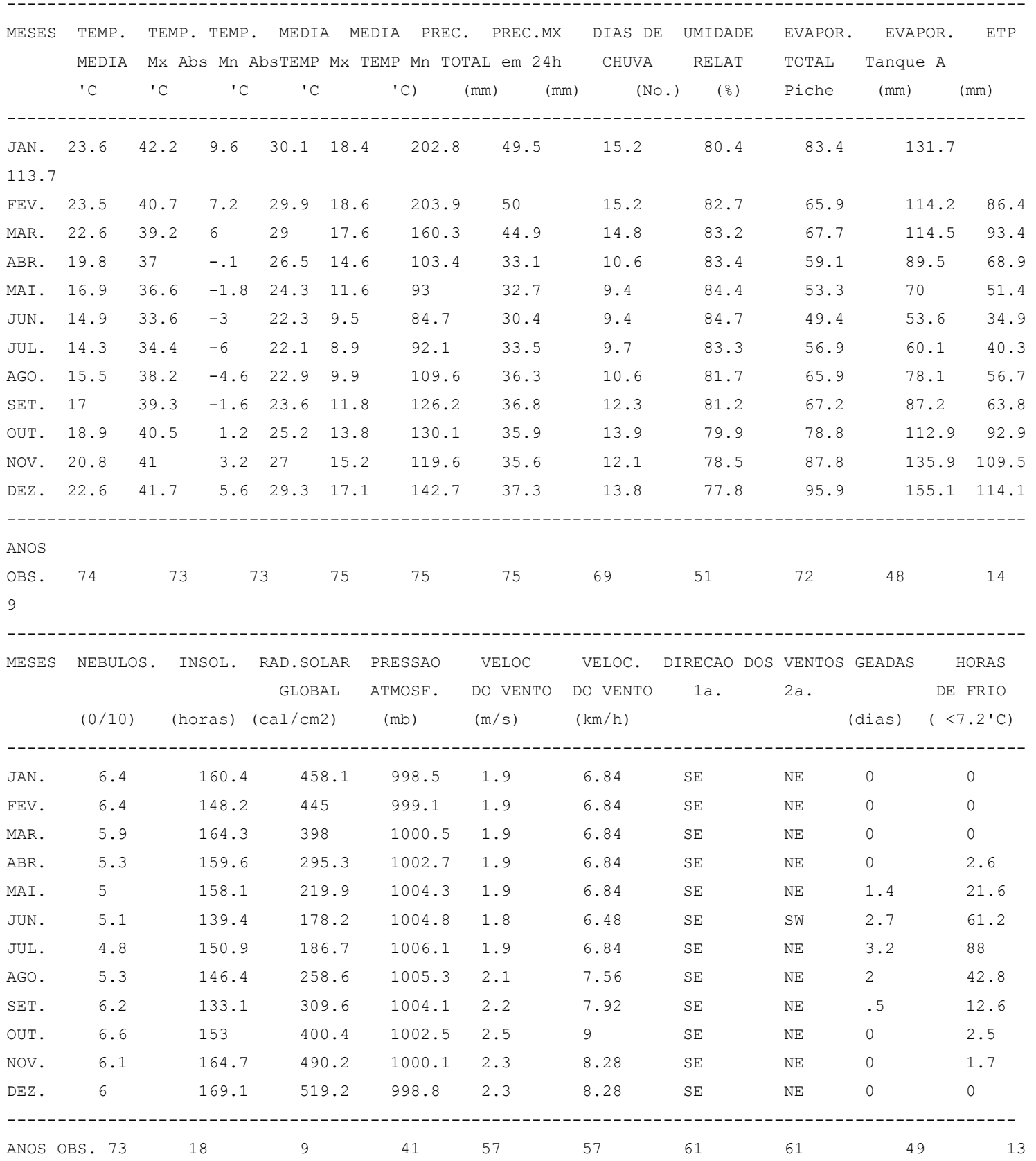

Série histórica da estação Meteorológica de Urussanga 


\section{ESTACAO METEOROLOGICA DE LAGUNA}

LATITUDE: $28.29 '$

LONGITUDE: 48.48'

ALTITUDE: 30.89

Metros

DADOS NORMAIS

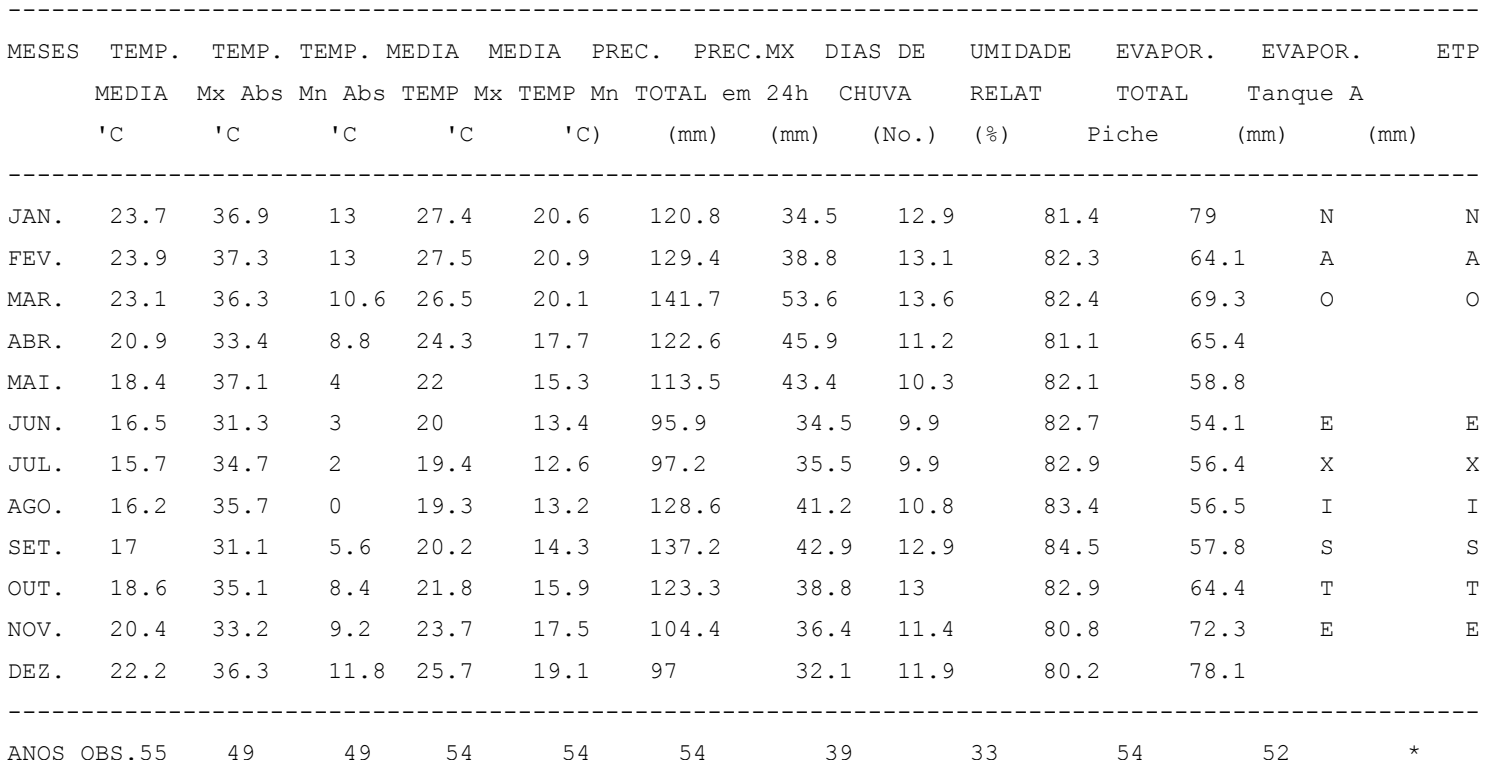

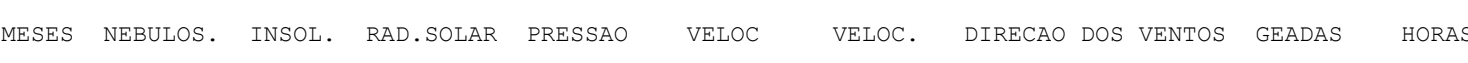
GLOBAL ATMOSF. DO VENTO DO VENTO $1 \mathrm{a}$. $2 \mathrm{a}$. FE FIO $(0 / 10) \quad($ horas $) \quad(\mathrm{cal} / \mathrm{cm} 2) \quad(\mathrm{mb}) \quad(\mathrm{m} / \mathrm{s}) \quad(\mathrm{km} / \mathrm{h}) \quad(\mathrm{dias}) \quad(<7.2 \mathrm{C})$

\begin{tabular}{|c|c|c|c|c|c|c|c|c|c|c|}
\hline JAN. & 5.9 & 207.9 & $\mathrm{~N}$ & 1007.4 & 3.6 & 12.96 & $\mathrm{NE}$ & SW & 0 & $\mathrm{~N}$ \\
\hline FEV. & 5.9 & 172.4 & A & 1008.1 & 3.6 & 12.96 & $\mathrm{NE}$ & $\mathrm{N}$ & 0 & A \\
\hline MAR . & 5.6 & 192.8 & 0 & 1009.4 & 3.7 & 13.32 & $\mathrm{NE}$ & SW & 0 & o \\
\hline $\mathrm{ABR}$. & 5.2 & 178.7 & & 1012.1 & 3.6 & 12.96 & $\mathrm{NE}$ & SW & 0 & \\
\hline MAI . & 5 & 181.3 & & 1013.3 & 3.4 & 12.24 & $\mathrm{NE}$ & SW & 0 & \\
\hline JUN . & 5.2 & 156.1 & $\mathrm{E}$ & 1013.9 & 3.4 & 12.24 & $\mathrm{NE}$ & S & 0 & $\mathrm{E}$ \\
\hline JUL. & 5 & 173.9 & $\mathrm{x}$ & 1015.5 & 3.7 & 13.32 & $\mathrm{NE}$ & S & .1 & $\mathrm{x}$ \\
\hline AGO. & 5.6 & 165.9 & I & 1014.4 & 4.1 & 14.76 & $\mathrm{NE}$ & SW & .2 & I \\
\hline SET. & 6.3 & 143.7 & S & 1013.1 & 4.3 & 15.48 & $\mathrm{NE}$ & $\mathrm{S}$ & 0 & S \\
\hline OUT. & 6.4 & 167.7 & $\mathrm{~T}$ & 1011.8 & 4.4 & 15.84 & $\mathrm{NE}$ & S & 0 & $\mathrm{~T}$ \\
\hline NOV. & 5.7 & 199.6 & $\mathrm{E}$ & 1009.3 & 4.2 & 15.12 & $\mathrm{NE}$ & * & 0 & $\mathrm{E}$ \\
\hline DEZ . & 5.5 & 221.4 & & 1007.9 & 4.2 & 15.12 & $\mathrm{NE}$ & $\mathrm{N}$ & 0 & \\
\hline
\end{tabular}

ANOS OBS. 54

51

46

41

41

28 
ESTACAO METEOROLOGICA DE ORLEANS

LATITUDE: $28.20^{\prime}$

LONGITUDE: 49.20'

ALTITUDE: 155.84

DADOS NORMAIS

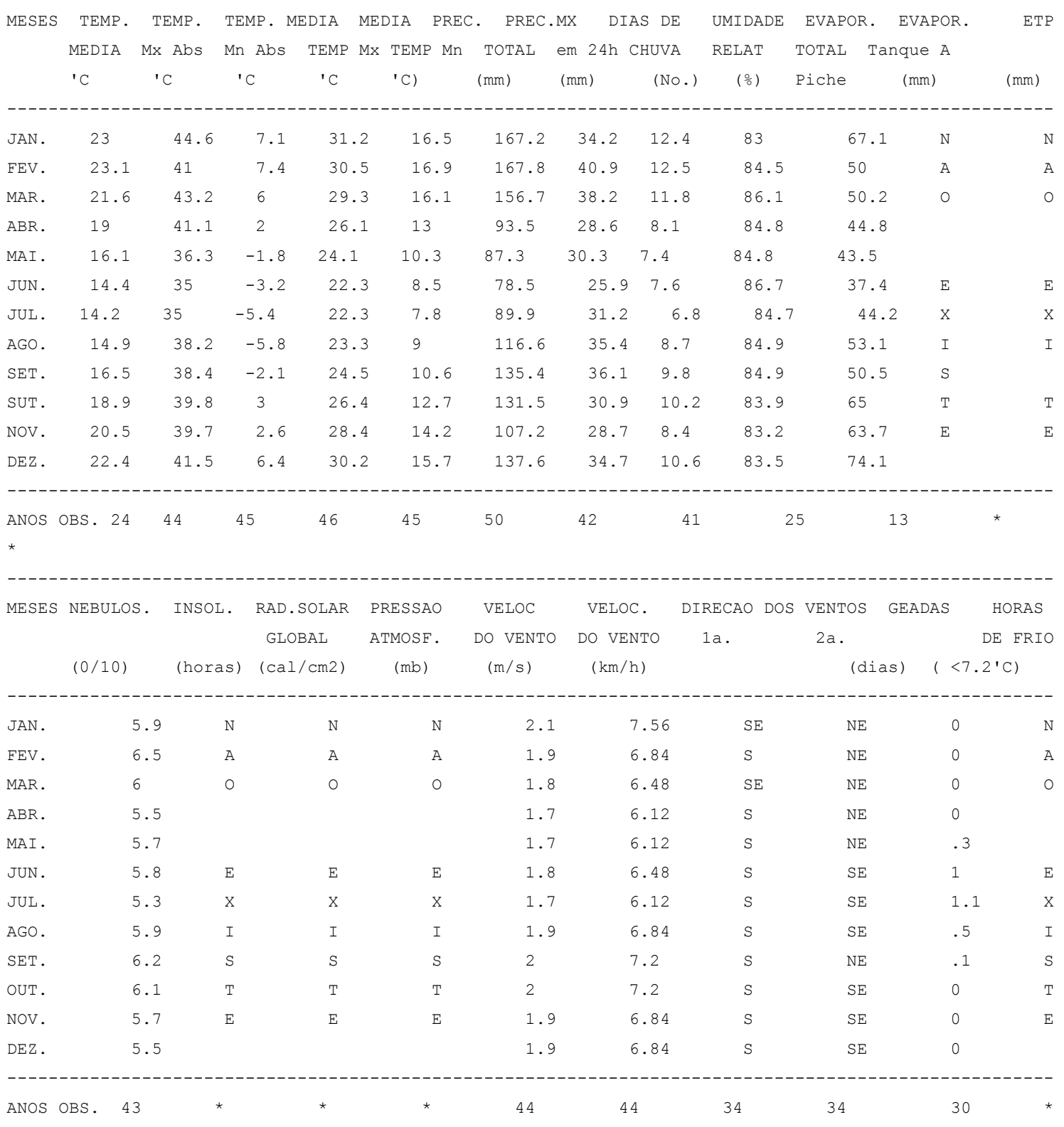




\section{ANEXO 11}

\section{DIVULGAÇÃO SÓCIO- ECONÔMICA NA MÍDIA}




\section{Santo Amaro da Imperatriz}

\section{Turismo de saúde atrai visitantes}

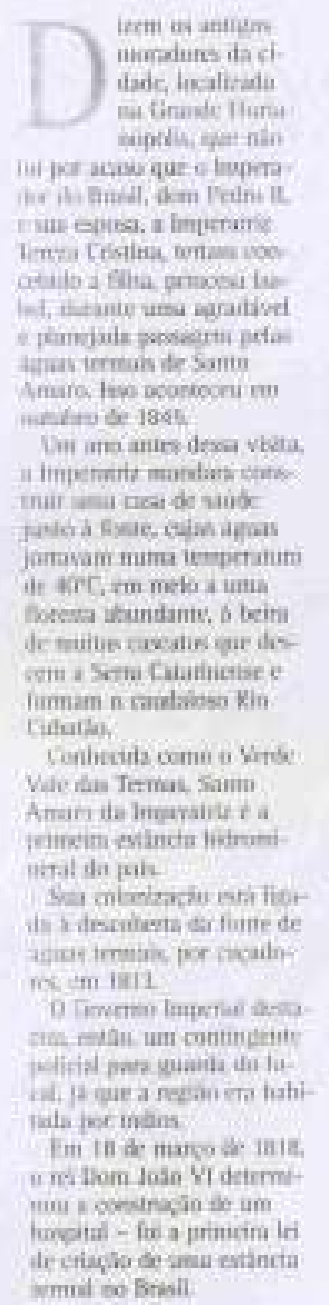

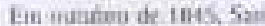
in Airaro da layicruirie is. cetrou a vaita do cresal imserial Dam Folie al e Dhane. Jensa Cristima qur mamile comesiruir um pridie caur quaras ev hanheras path os visamic em fraes de alivio pam susis dores

Em lienorngem à impe norizi a bodilidatic, yox $x$ Stamiana Califas do Cator the mis retatizada como

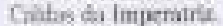

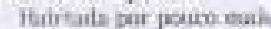
de 16 mil pascose, a cidait e colmia e furspoteina Vire do forjseno e As agriculium Compace o "cinturin veriec Li Cirande Foriesipails, (umtamente com a vitinhs) Antónior Cerko

Produe atedelatione yzven, tomatre milins vork.

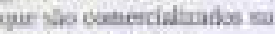
censibe Sin Jove

Silinate mas recestin do Honur if Sem in Tabukt m, Sann Amuro da linvera ifor t docate de diveris caingeims e salios.

Wite una ytio in Silm In Ris Cutatáa tam locad para a praniza de rafinge; Githerima Comintis de Dezia coviunte de actieciras for. munab vinios remansos cu yesrinas; e wa Salu do Rill Marine coen 60 metrus de

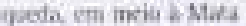

Alitutica.

Nins mones da iempicralia at Nerbs modos coter loctis fram esciecos de visiamto.

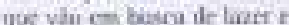
tranghithitobe

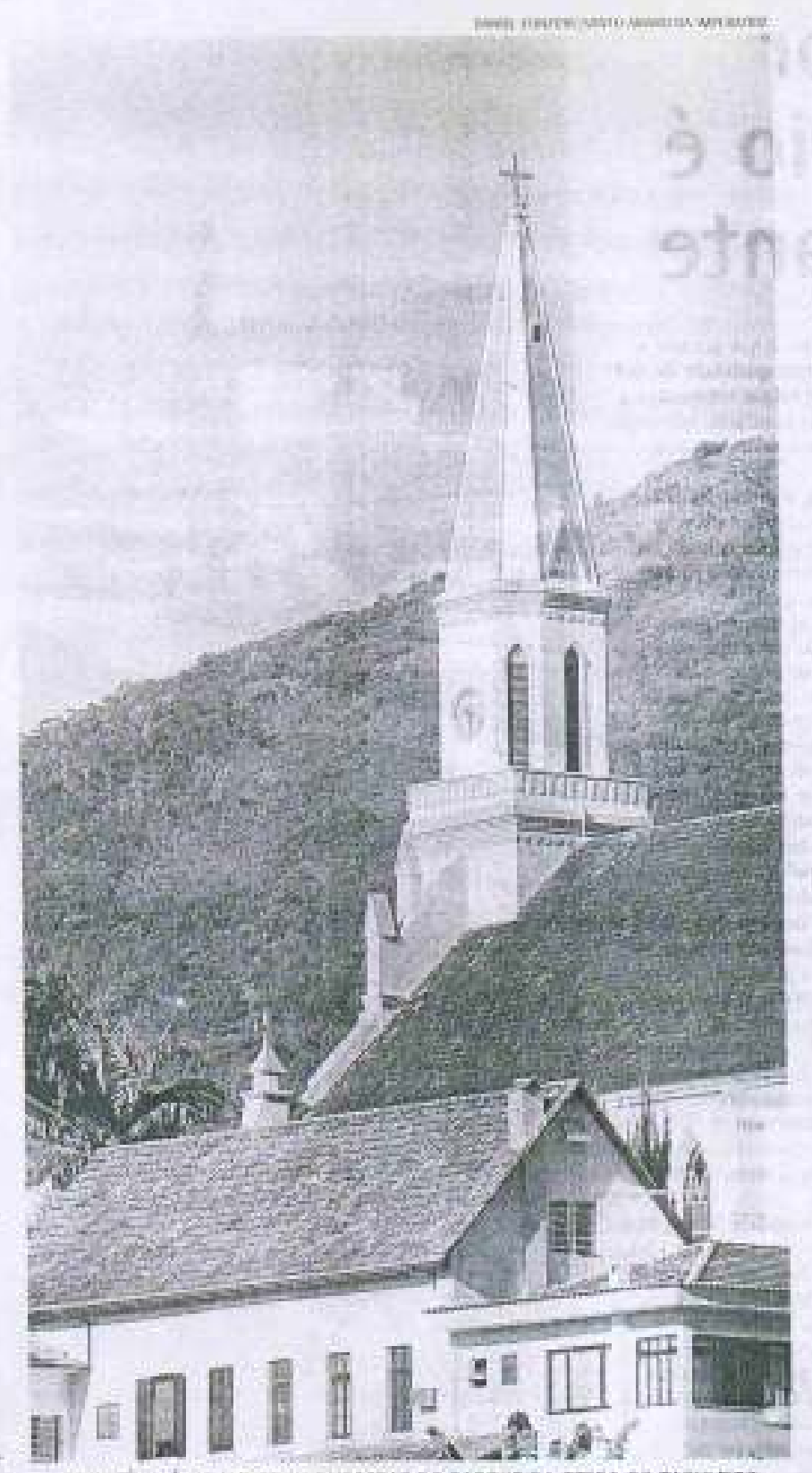

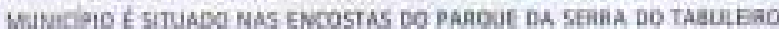

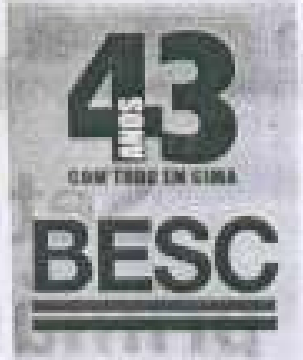

buscatumes:

sationed

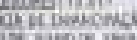

Belezas com

fama pelo mundo todo

As andas fermais jome do in

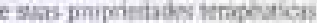
suin fama intomarional, atraindo

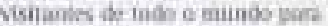

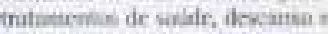
rouvermesimimto.

Possul boa mide haidera com

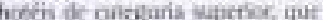
oferecenr aglum jermans un upgles. de lieismas rumal

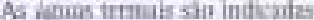
parn tratamento ites futrobs toros

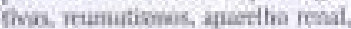

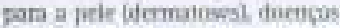

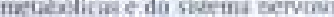

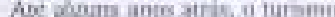

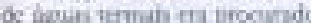

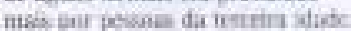

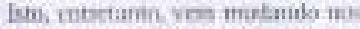

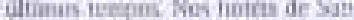

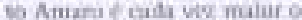
mimen itr kwors. cerso emi ha de mit e arinçan, yae se dediklami

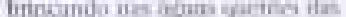
piscina

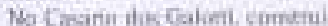
to ent comb acurtuhb esaso jesse

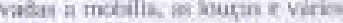

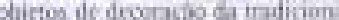

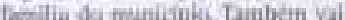
cuntecer a Camereintwa da Esyrin10 Suess antipe convento de fretfas em coibs Gimoes, constiuios m 1904 .

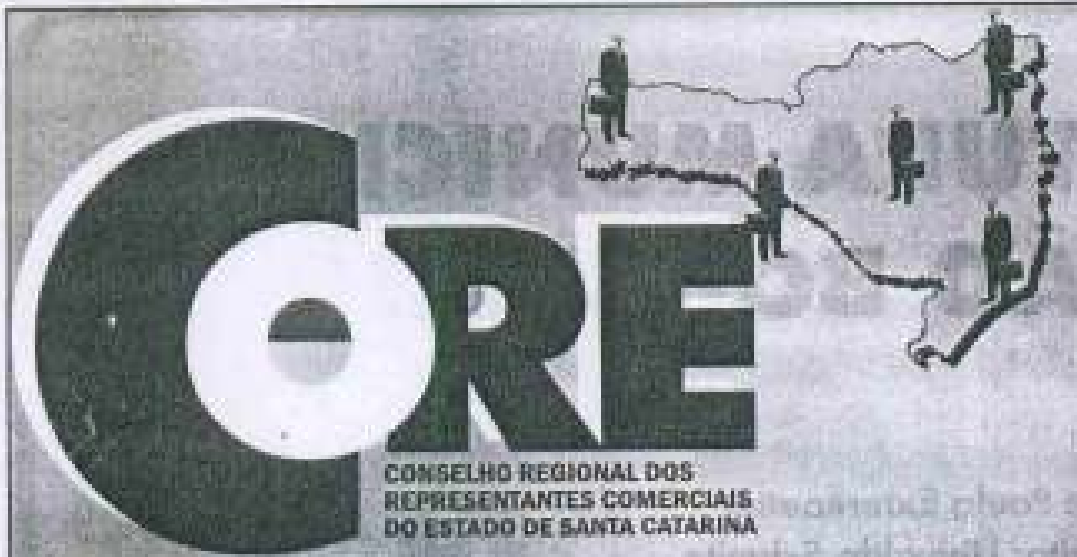

O Representante Comercial é um profissional que no exercício de sua atividade é responsável pela distribuição de rendas, gerando empregos e movimentando a economia em todos os

municipios catarinenses.

E Representante Comercial somente quem tem o registro no CORE www.coresc.org.br 


\section{São Bonifácio}

\section{Setor}

primário é dominante

0

ariso a STo Do

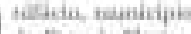
to Giatair Hiarie. wopulis, ifele SEdii wata asfida. 19. J e e un beto prassiba Meite verde, sifticis e que se metihum minimite alo es primsines sinuin de cue a vi dat it anda mats rimo mah liegm

A walte vile uermàticts ainda bein tradiciunat e pea ticamente pouniale gelie meme familis que chogh rain a milias en IBfot, $t$ pota tranuilihate.

A popelsosin, de powo mais $4 k 1 \mathrm{mb}$ haticame. upidarse to befras naiurais so lonal, que zanivou o utubo be Tein dis Verdes

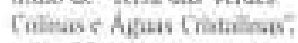

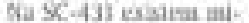
tanirs, de cenite peste-se bhwror toda a botca natumi a mula. \$oo bonilico iccabsy est noew por truar xe do Sanio Patrocim is Wesipkilla, metain de unde vicram es arajpanies

A ativitaie principal to minsopio s is prisinia coin b criegra de mak de is mill ribogas de gials ide oone $e$ te iriis, o gque caloode a SSo Bonlliaso o primarim lu thr no neteins molualive dexhe wotur ines us 30 murixipios ta Granse Finrand. polis.

Came outra tron of dedique + in apiculitus com umb prodapaso anual de mase de 10X1 yulis dx met de donta

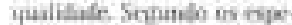

elaivat, eque fonaox a enetente quelialade da mel sio es halvas temgeranuss de Sin Honificios que no la in uma mettia amal de $17 \%$

Tala a proalusale tr mart, thas gaulíimio solvoire e pi nho é cumerrializiolo na jmopola itgliso da finande Doctunâpoilis

A aniculinm frtimsenta give do valor browo des po tutis de acioe animal pm. duzidise to municiplo de Swo Bomiticio.

lise wer madcindion nue reiponde por sigmaficaltwi parte de empecgoe e iend. do imunicipis, coih dosepur vendo ans poucm

A proiticiele de explamals As mudrifa nariona tem redo-

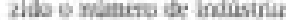
Inentficiadoras da matrria prime e je acahos por cum phete com as entpiesss ofi sctur extrativista

theye, as couces modelet

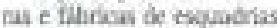
que consaguiram sxbexvive Gractham con matery im ma vinda de muitrs estailin. ersilitires. ocent in Mico Grussn

SEs Ecetificlo possua nait de 450 qublernos quadra Ses it fitce Atiniximate. nente ste dever tocal slat de Maka Atlandica greservo the $20 \%$ persevisan a hil

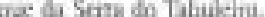

Dona de porsaexen beliss max, a cudate eem imvestido

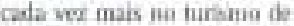
maiurrea.

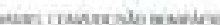

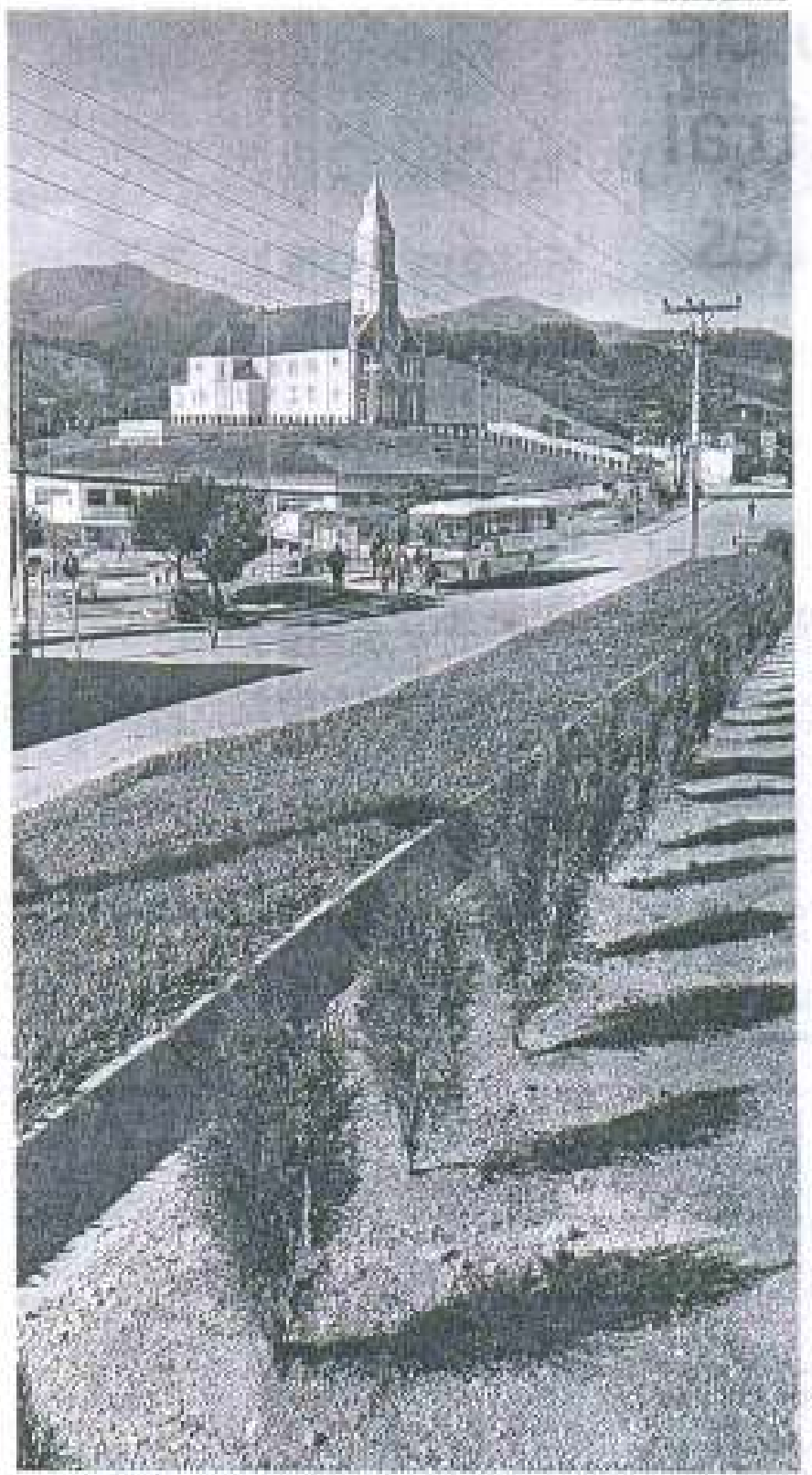

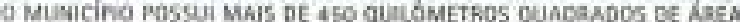

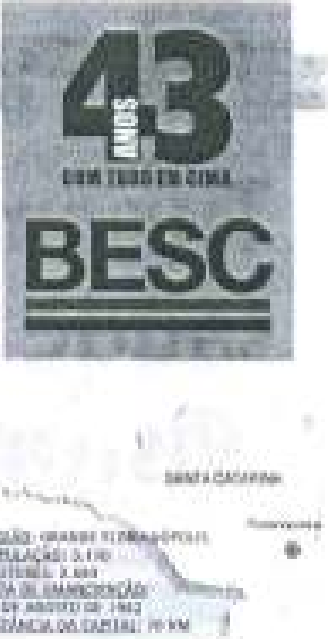

Cidade aposta no turismo de natureza

Nit ims arcuitentonica o natha

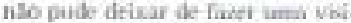

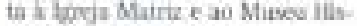
threve ofa cidade, que elidaim to coniar unt pours da coopeis doe primxirys imicrantes.

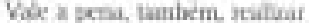

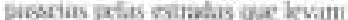
as comunitades ruais da ertiso Fatrit as peincigak foitus iursitcos itr 5 as benifacio dexacram se

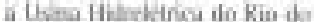

Fundin e su ialie, cum quedas de mais de $\times$ monros tie almurat umi catticnite aliemativa para ejucm yoer descussar do estrese da cilsode gontatr.

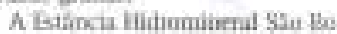
nifiktio a Everala Sent do sio

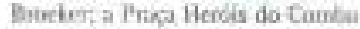

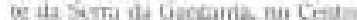
to ditadt, a que possul mierras

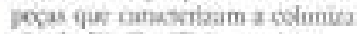

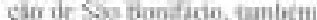
mercocm vama vista.

Exisiem ainda, viras goutas 1 sutadirs pos toibs o municijos. locahi idsis jara passcion conlice.

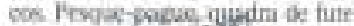
bol suigo, nens yifoss des bilinas ecubiqperic do

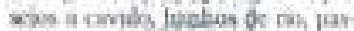
sebs $\mathrm{cm}$ pantr perail $\mathrm{e}$ playgreul

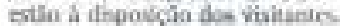
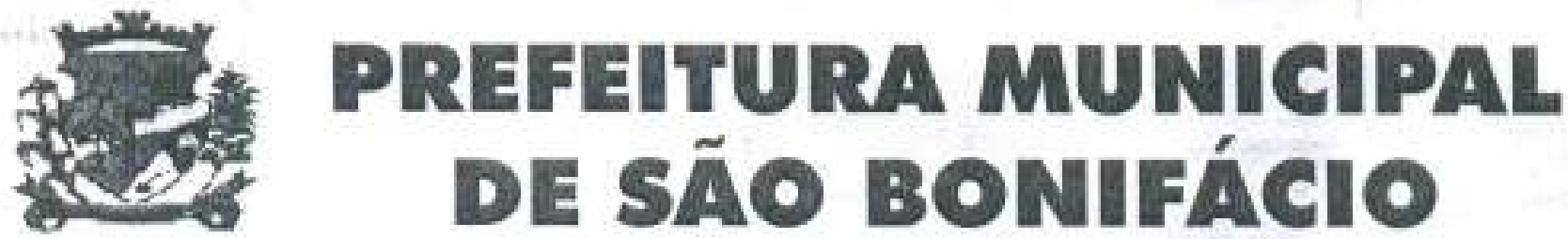

Prefeito: Paulo Exterkoetter

Vice-Prefeito: Univaldo Schmitz

Administraçao: 2005/2008 


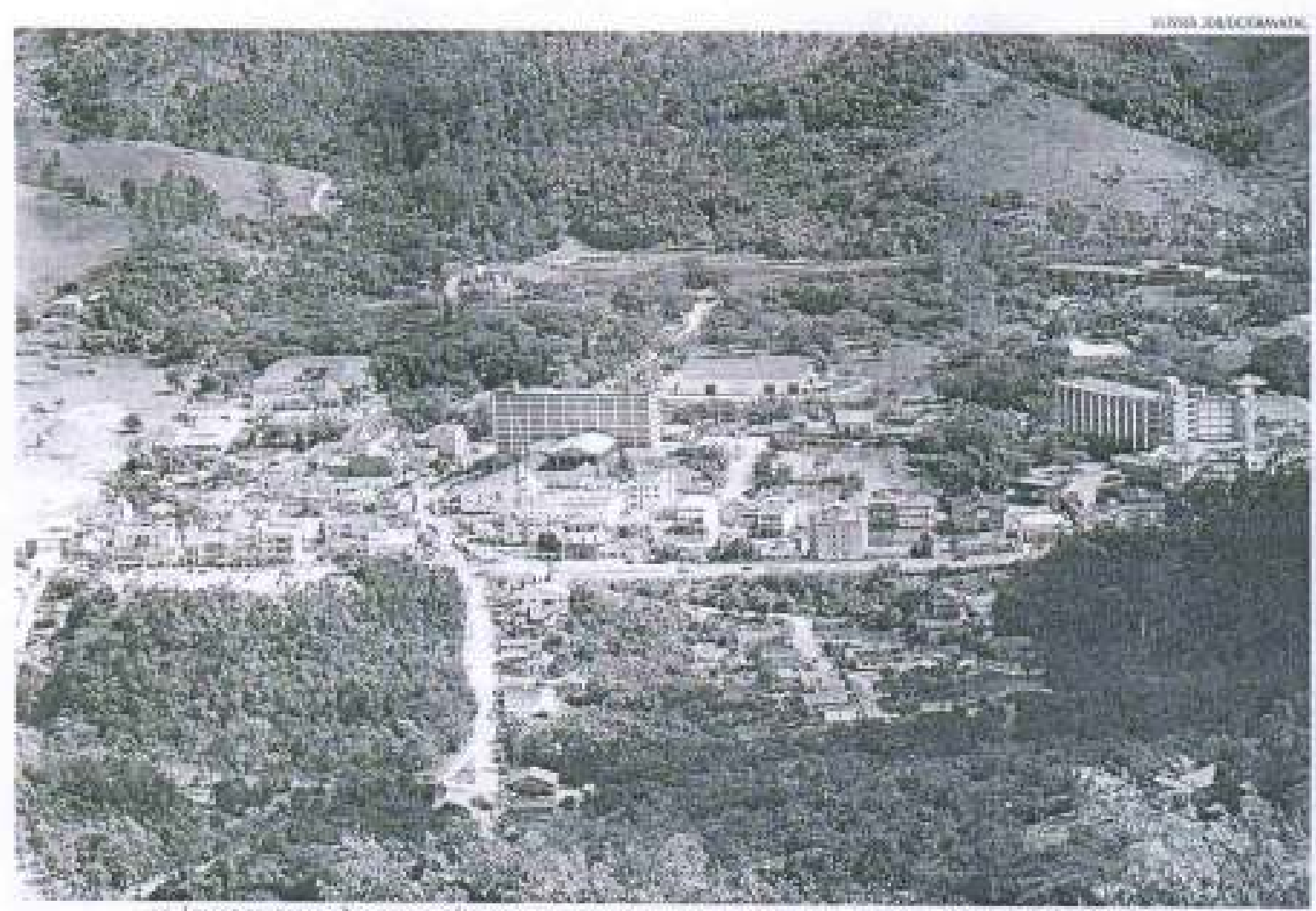

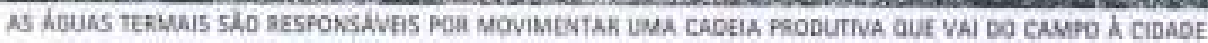

\section{Turismo substitui agricultura}

povoameato de Cirwital, comin a du malor jaite da cidados do Sui do Eabo, devrese as deslockstemo de munatores a Colönia de Sunto Anionio bos Aryos da Lapuna - a atual Lagura, toe no passaibo ahronga bela a iegios Sut.

Fo 1842, Jodo Martin de Soure am dos funduifoes de Gravatal, estableteu-se to bo-

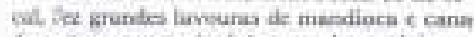
de acione, corcerira dois enigenhes e dots

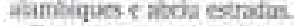

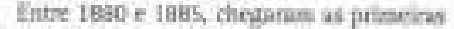

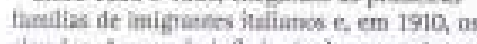
alomies, hpesar de influencia dessas exmias, a inatiço açariana des frimtinus colanisulores ninda ef furte un cidade, tamio ou anyatetura quarto nos hilinos populare.

Granatal foi derida a muricipio em dezirehoo de 1961 . Sums terma fentis garzersam 0

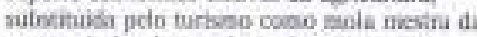
coonomita local a pentr th itrscobera tias acras termais

Responsiveis pela desenvelvimento taristion

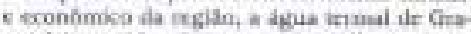
vatal e crissiteriala soseguinda medhur to mundo devilio ás suas proprodades mediciness que so sto superadas apenas peio complew de hux-Les Thern, na França

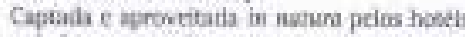
instalados no couplexo termul, a fogea jerns:

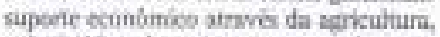

uma umperatura medla de 17 - C, com vas bo de so litroe por seprinda

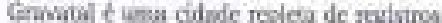
histaricos, como pot evemplo, a loncja de S\$o Sebontian, constrabita hil mais de 150 anes e

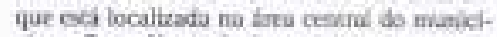

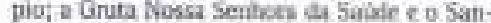
tuário da Sagrade Coencion de Jesus, viskas considicrarias chrigadirias.

Tumbem t uma bos oppalo psssese peta centro e coctprar zigumiss peras do arvesanito bocal farrose pela qualidarie dos acolchoodos de Ut de cameiro, travesseinos de pesa e pluma de Banso, mancos e tajetrs canfectionndos $\mathrm{em}$ iears mamusis altan des peczs em cerlmica. tinco e croche.
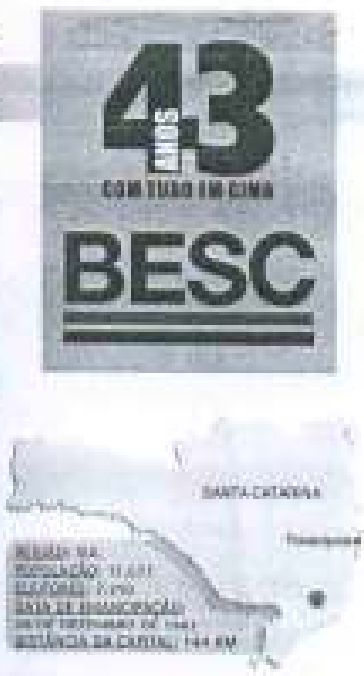

\section{Saúde que vem da água}

O main atrativo luritueo de Gravstal ta a Estancia de Agras Hit. tromineraic que leva ate a cibade milharea te viskanties de todas as mocion do liresl.

Qs princitats hotis tím pisadias coletivas e hentoeses indivibaals

nos veartamenios, contarsfo tam htu com excinte infra - strurun de gastrunamba $\mathrm{e}$ larm.

Det des passaios mais morcerifdos nas termus do Gowatal é feto de charmete, onde os taristas eoger imsniam uma volia ove vethes Impes da colohtin

Sose de Melition, apebitato de Carazs relos panganheires, t um

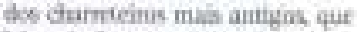
hi mais de 15 aves levia on ver tardes para cothetcer us powios mals bonifis do regita. Ane se apo. sentar, Meteiros trabalisve na apoicultuma. e descutetu no tursmi uma nowa fonte de fenda para कै famila.

A rexe hatririz de Cromal e cunsideraits de jrimeina linha, mo hottis if siegora intemacional. cahinas, ancas de campins e poo.

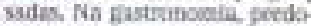
miman os prates da culiniria it Hara. A citiade conta cum boa in fts- ctrumina ite luer $x$ de entreit-

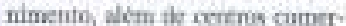
cisis e poteins ofe venda de stodit. tim tipicon.

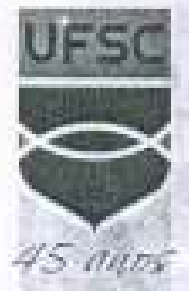

\section{Ampliando e aprofundando a formação do ser humano desde 1960}

UNIVERSIDADE FEDERAL

DE SANTA CATARINA

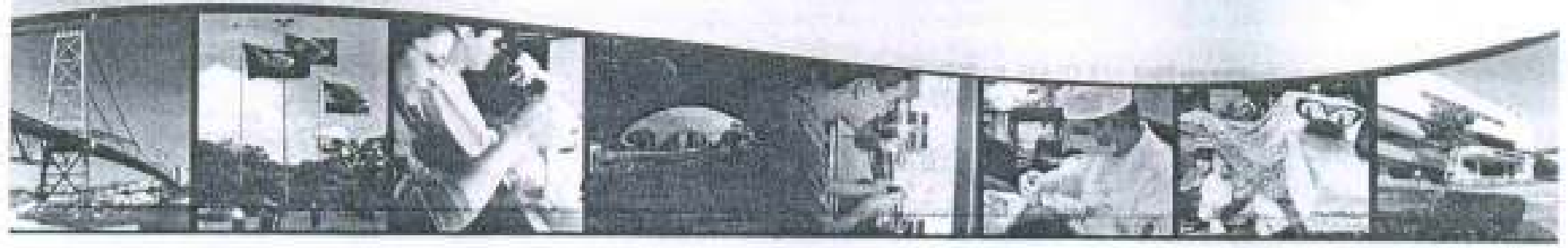


$4 \quad$ Águas Mornas

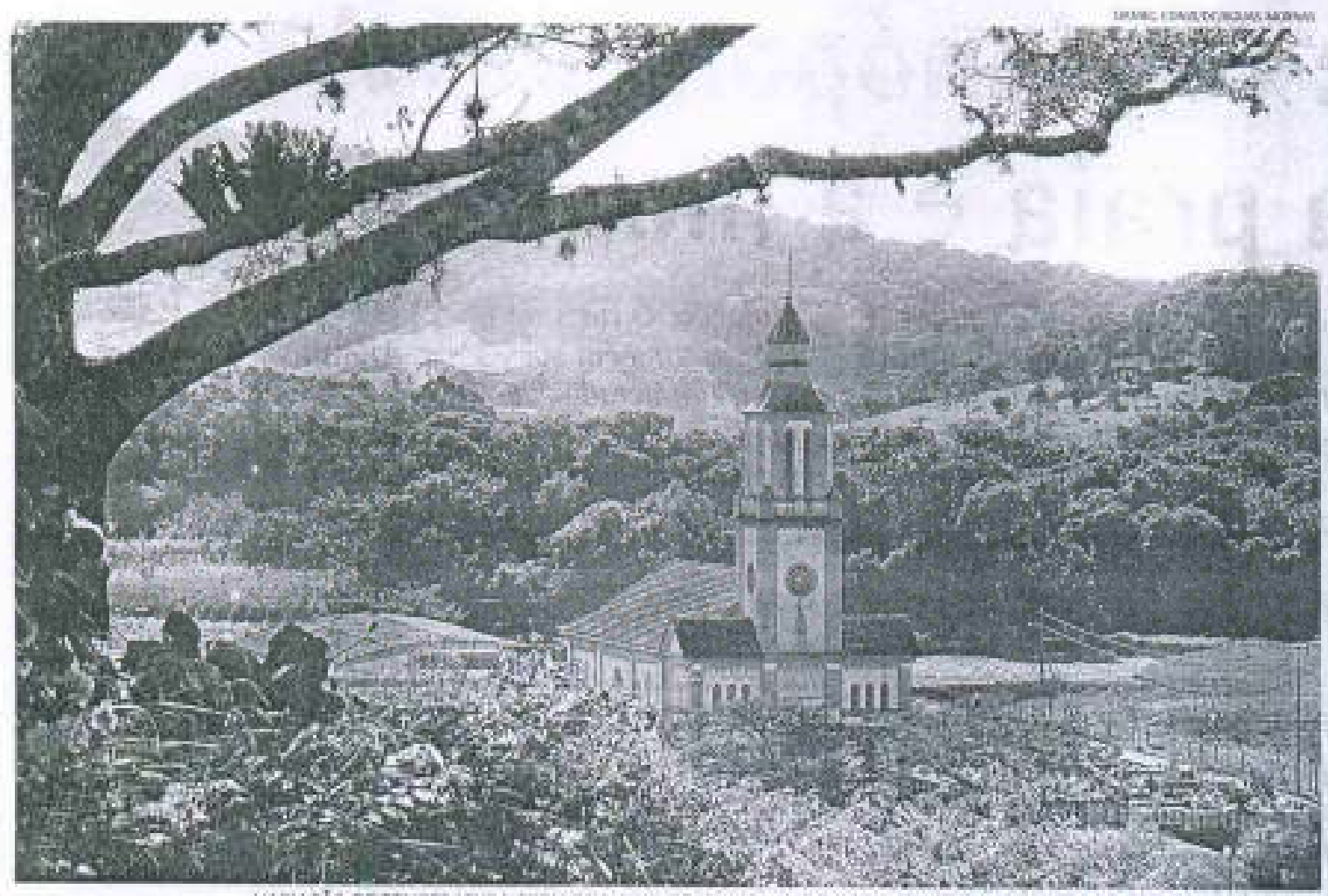

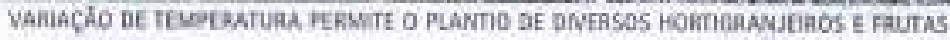

\section{Piscinas termais famosas}

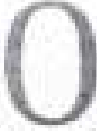

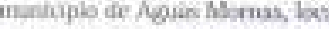
abon tia Grande Furiandpols,

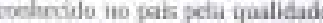

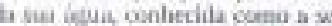
finda siethar do munby por wart ckitalu realtasia jur notions de llotem-Baden. na Alrmanhs

A yualiatoe de tequa du rodiso bes atna apenas de Vidiy e Aus-ios Themes, na Fanca

A urifem dosas atia, que eniente de leme.

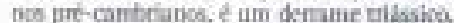

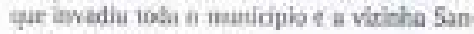
ii Atmane ds impicrikriz

As atuas do municipio sio classiticartas o

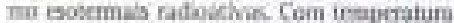

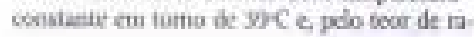

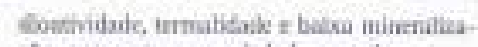

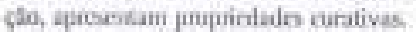

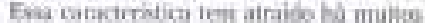

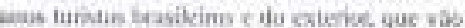

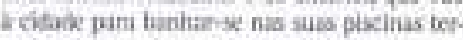
mais, o seu maice cariko de visitio

O mosinicute de visitantis ó intetnsu durane lods is ano $\mathrm{E}$ a iemperatiun de agua namita. we curstante zui 3rC. $\mathrm{E}$ Indesada no bacamento $d z$ reunuithrog, anthes antsoos, gocas $c$ dois itumiticas im mualyoer jarte do cono. flis Farte bos turitas gax frocunam as ptsc. nas termais nifo quezrm aperas facer truta-

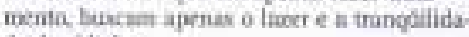
Qe da valiete.

Apuss Mornss cornoçou a ae colanisoity em 1897, por cohnis alrmiks que apurtanim ni

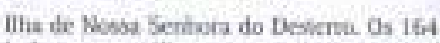
imigheter catclicus c evangticos instalaram-

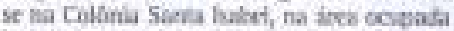
hoje pelis muelcipies de Assas Mumas e de Ranche Quximados

Antes dos alembes chegarms i mplin, o indiarie de Aquas Murtas ji servia de itinerivio fes trepeires que vintam ife Laver com seus produlos para yender ma Captail ina tooca. Chamaida Desterol, o que afudina a fextemerttar o crestrienim do municipio as berto de sua formacta.

Calcula-se que 95 da populagso dexen: dame se alesalien $A$ diack minntem as suas bets gundes cukeias perniaricas - Vamiem Gran: dr, Seva Isabef e Teresopolts ; wis fuedidier por eolanos entre 1837 o $186 \mathrm{i}$.
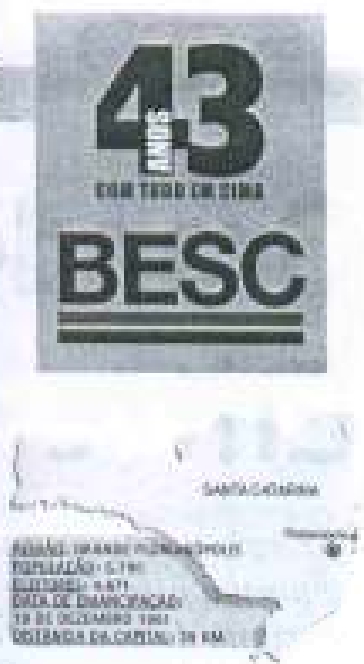

\section{Hortigranjeiros predominam}

Devido as variaçūes de teseperatura que ocurrem no municipio, é possivel cultivar peodutos hortifin tignnicinos durante a ano intrine.

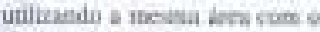
sbicema de votizin.

Apars Mamias é o maint prody bor de hortigraxicins a mota so

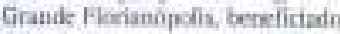
peto dima.

Destakr-so pravol-mpe na

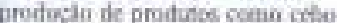
ta, hasati. temate cowive-flet, repo tho pimintio, ceocura, aloscaxi viogen e trocanyn.

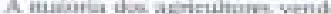
seus protulion as Ceace, in Sto Jonit

Marest Fidevico trabatio he

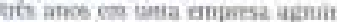

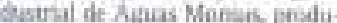
zinds muilas ite homilnutignampine

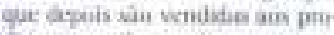
Giteres nimis para incrementar aे perneuctao.

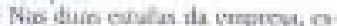
tho plarsalas mais of t, 3 milhibo to imuths de coure, regelhn o es-

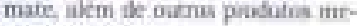
nos exprowivis

Squnda Lides do empresa, at motas denvoram cesca de 30 dias to Verdol abe florem pronias jar. o pluilia.

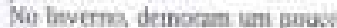
mais, de wa so dirs

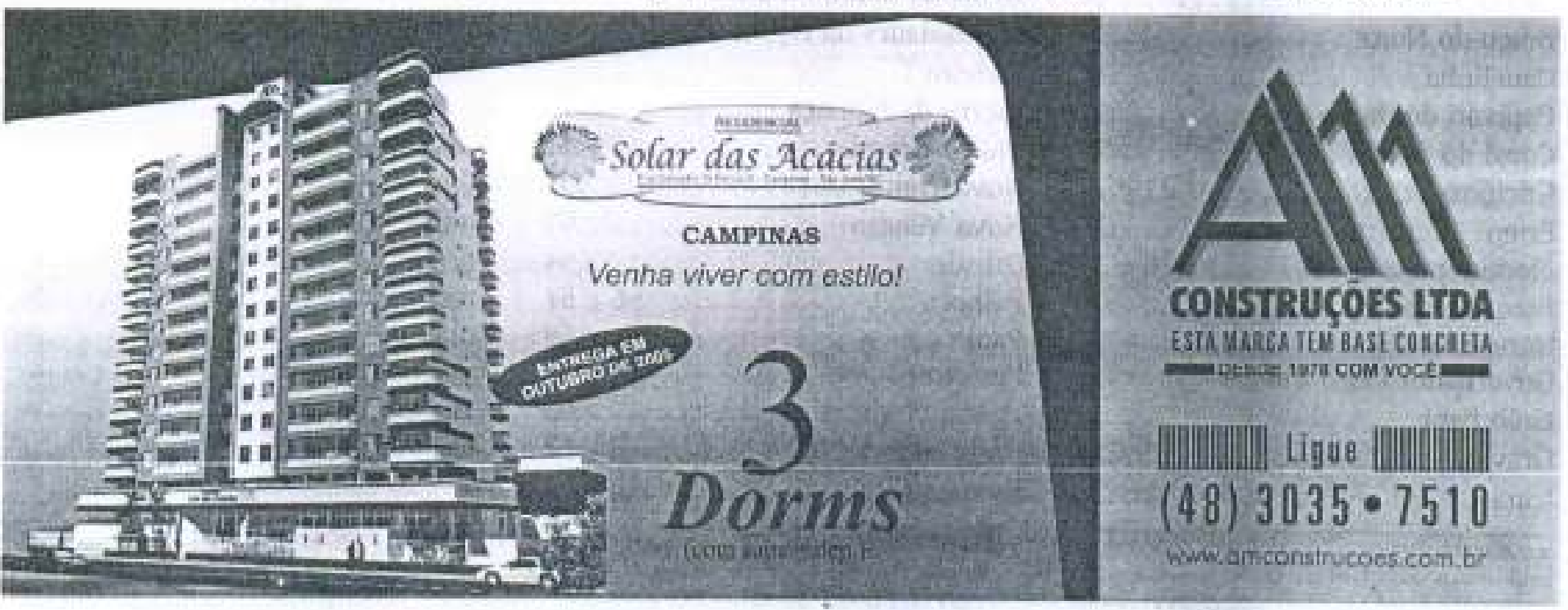




\section{Dupcuntises:

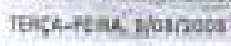 \\ Presidente Castelo Branco}

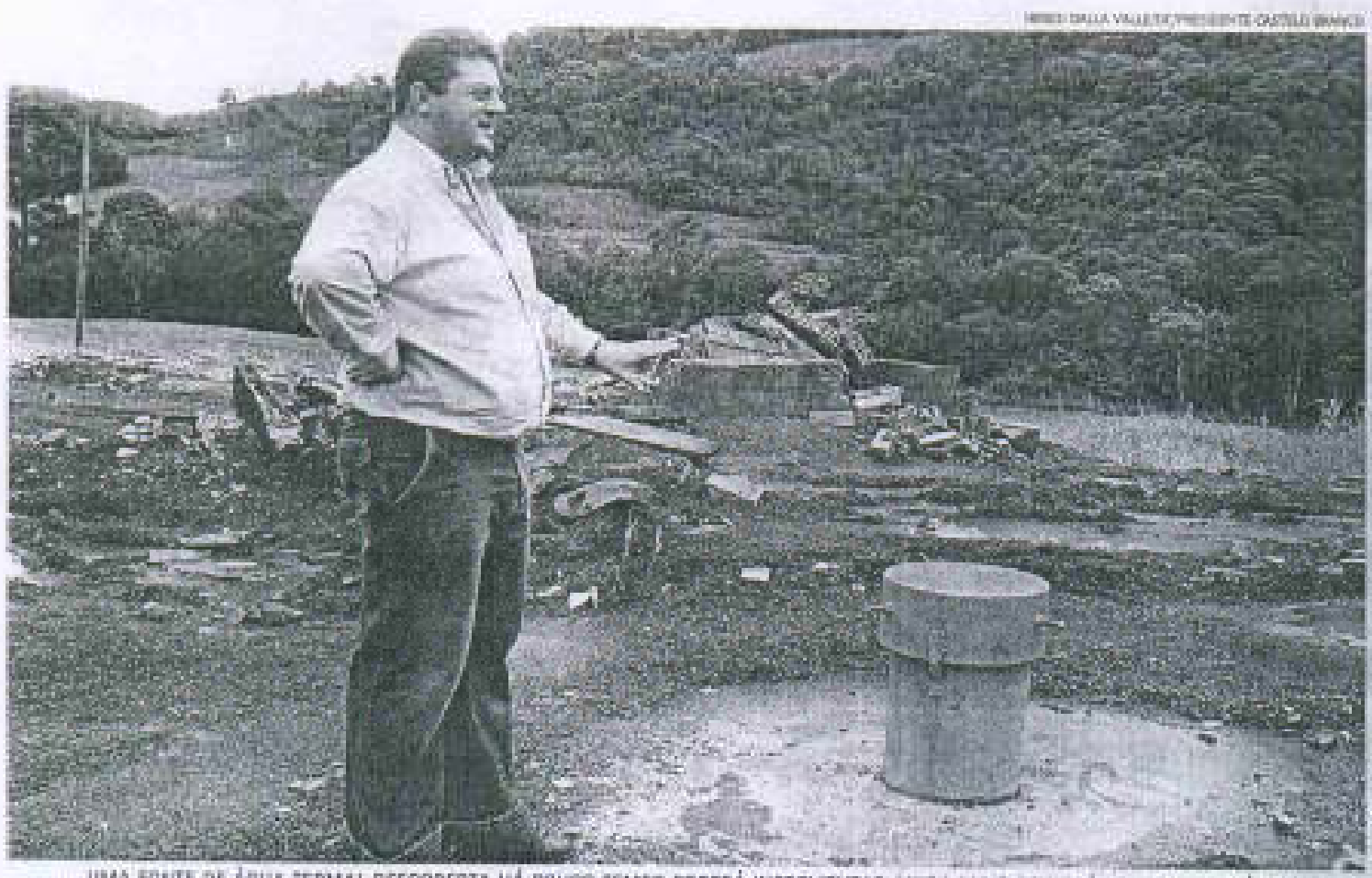

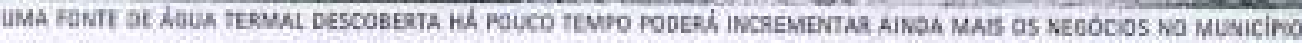

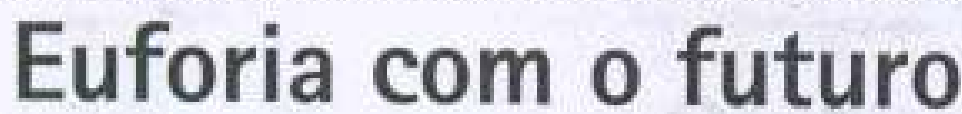

$\mathrm{P}$ condetie Costele Brancr, nova farsa fu Meia-Girstr, tom hoje uma das makctes midas per capita de Santa Catarins, de RS $31 \mathrm{rmil}$ anuisis. 0 jemiltado impresinara pora verta cladule bo pequens ande verrm 2 mil prososs ebl perieita tamaina.

Pam o pectioto Alkmir Doeningos Mlaco

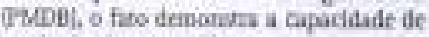
produgla da comuratale.

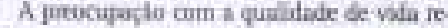

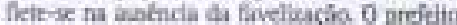
acrotita que ayenas cinal aituitas que hoje

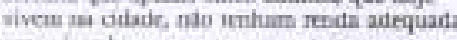
pan viver hem.

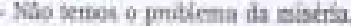

Ceras of $1.6 \mathrm{mil}$ hatroutes vivem ma drea nual, o coe tocra of feso ainite mais inpro: siocanic. A allvidatr syropeculdita, basesda na wiogculurs, bevinocictin de lente e aviculitaTh, comina crevenda. Finj, Proidcute Coitt Io Hranco te 358 propeicdades rumis, expo thates por 10 comentitiates

Q utimiono com a fucum da cilade chesa

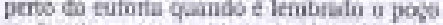
perturndo na comiandade de lintis 550 tata. Coin $7 \times 0$ nictros de protietichide, $s$ a um cus. to de as 700 and, o poco tinha cams otjetho solvidonar u probera isbrike que o menidlik tem com o desabastecrmento de ás-4.

Na deve apenas insalver a problema, cim a trande vallo que apresenta, mas deve, em curwo esgoso oc icmpo render lurvos pana o imanicion. 0 motivo: a asu. upesentia carac.

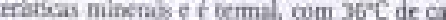

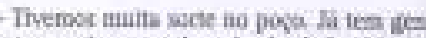
If interessada sa coplntracio dos balneinos,

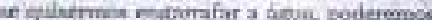

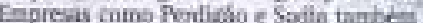
acompanfape coen interesse, pois a bauace fito munidipal.

A expectutina $t$ de que as peoperas intis

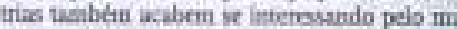
rokipio oced a oficta de revursos laidrions: 0 besafio asora sera a instalogito de 10 ) iquiltometros de zeite camalizusta ruia etintartsa de cavlos pessan de Rs I milhiso Espera-se of fim befinitivo de isinpos cresto o ds itcima etiaoors, quacde o municipio pecelsois fuer 0 uarngerse diario de 130 mill litron de aso.

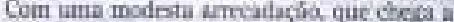

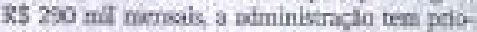
thakb sside e educagla, cum transerte gnttutho para enudevier bo ensino factanental a0 sifjeriot can garanta pars a prodocto - ecollca o jue-
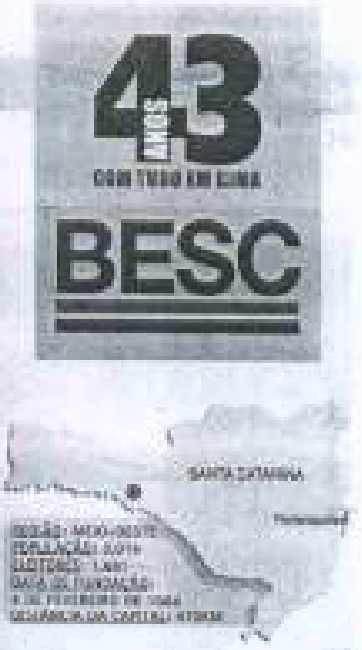

\section{Produção} revigorada

Dejetivo primordial dentro da atividade do peodutor de Presidente Cachelo Branco te agregar valos as propriedades locals, 0 peefetio Ademir Motto emende que o produtar de ine deve implantar sa propriodade sstezaus jara op pmcossimemo de laticirins que meit. tam ens quefios lokutes or decraik derkades, 0 mesmos cocors com a cime. Quem cra anumais jara cone pode parn uas a producti don eministas mentar van peque to watrofoumi

0 poodinar de fruas, for sata vez, esta senda ntimituto in fiter our gelicin e sucos, proctuair o are.

- Tonua tambèn a erva-mair wail, ha posshilidade de agecar murto valor a iussa producto afirma o predeitn.

Comesals a surdir en enereengt arnios qut juntam as canctens? cas ficicas e a nanureza da didait.

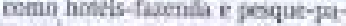
git. E a csons dn muresn then da fimilin Sunori, eqe olereor, ein im mesmo elehirnte, piscina, nes Gumnis, poesoda $e$ acudes

Tenns um grande prittitru nie Verita c estames aratiando it bce sa tstrutars de pesque pagive qur cem uma exockent procuis duran

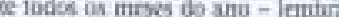
Oexrrtic, Dowaths Sartor:

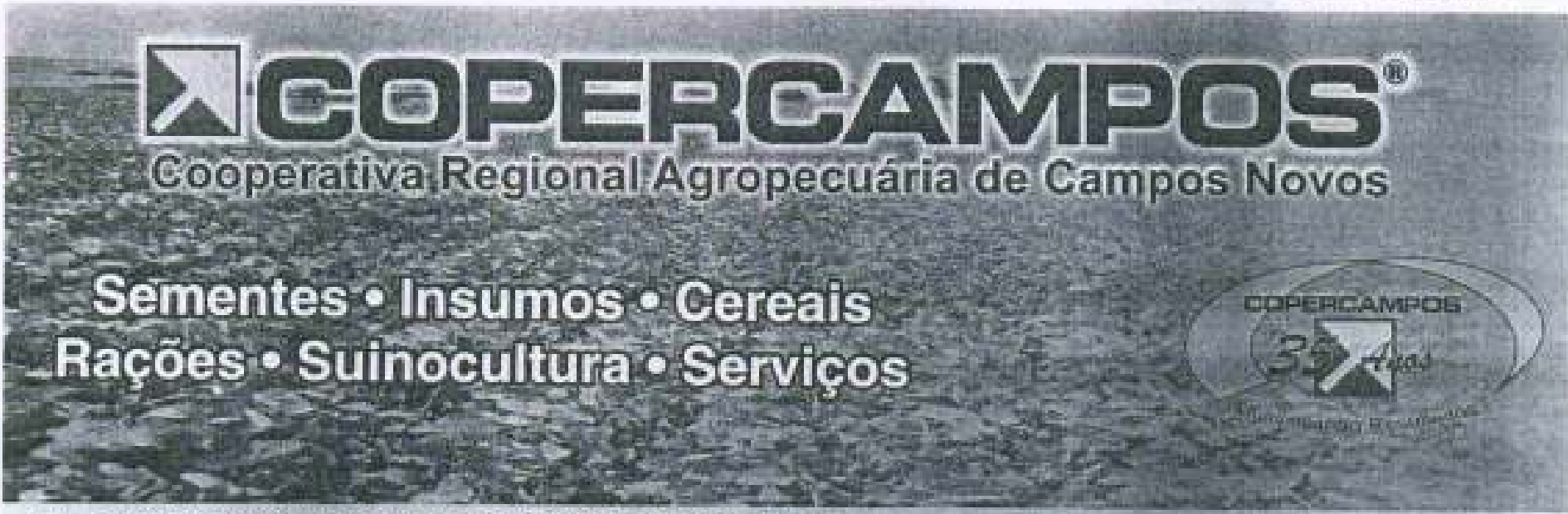

Matrix: CAMPOS NOVOS, BR 282-Km 342-FONE: (49) 3551-0011

Filiais: Anita Garibaldi, Barracăo(RS), Brunópolis, Campo Belo do Sul, Curitibanos, lbiam, Nova Veneza, Rio do Sul e Tangara 


\section{Água termal alavanca a economia}

4

sahecile en torio - paia, Pirnduba in lajir on Euris. ca conoumion. Mar 1 hivocie to cidade fol mat.

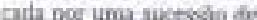
Putas e or eficulitader Co moga em $15 i n$ quieda : Broml Saltway curnoruti I Ermalu de Ferm 5 ibo Fuslo. Rib Orande do Sud $A \in$ en. irros nocte-americuma teve wrovilade of mintatat, tin chamabo babm Vake do Rio lu Priar, um arunpentryo hees seus cperiaries the cum main.

0 nodeo damouse Vila do Rio bl Frint, asim per. travecende ant in if fore. stim de 194ak quando fol dicradt à culegrna de me ticipa. A comanidatk ado. thu num novo Dome, Pinutabo, eue ens Iupl-Guaranl

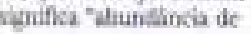
peras: Us deturnatote in nover pant, yerwes da. thamada "collala vetha" tanidata

Passata s fase its extra. cio de madelors arvidude comitriiza que dominou as as decalas de 39 a 40,50 . cons a parsilioglo das ativi. clabes do frigortilen local, maltas familis que vivam

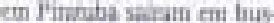
a de novar cotattunidailes de anhulho rume as Deate In Firado ou Note do Para

Mat uase ntrra realiatude

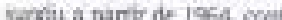

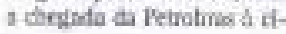

dede. Se os trabihins ila enproa nito descobeirudo of desejado $\mathrm{e}$ smihado jetiobico. grrviram para dar vazao a um lencol de agess suifure235, use se oridinam en metres.

A igra uflon com a tempenituma de 36, 5 - C

A descoborta mubran ite ninu as nimus di economb iogonal es assim, wargar o complexn trimal formado pela Companhas lildranire Tri de Puwiba criada em marco de 1975 . Com a chegala dos visitambes airat das pelas a jass zedicinaks. cinryou 6 desenvolvimenio is rode botelein que se itsblou an scu tober do conplexs de banihos trmak $A$ inctharta da eirutum be

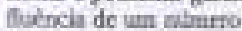
crescente de turisiis Couno sectaipue da cidode e a Unina tiedretertor ME chatinho, um dos grants: empreeolmentos errerictios do Btasil. Sus capacida de de pcoducto et de 140 andiwats qut scral o suth cente part abasieces efr $569 \mathrm{e}$ do catoume de Estade. 0 lago de 56 yulometros quadradse formaib seda us

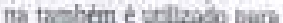

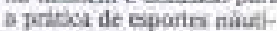
cos e pesces epoutivs

Localiobsa a 16 quibome: tous is preimetre urtand oc Pratiba a hidrtiction eo entur es pontos turisticts mativ vistados uma protbadlade at 764 huits $e$ pousaitas garantil

\section{Diratuka}

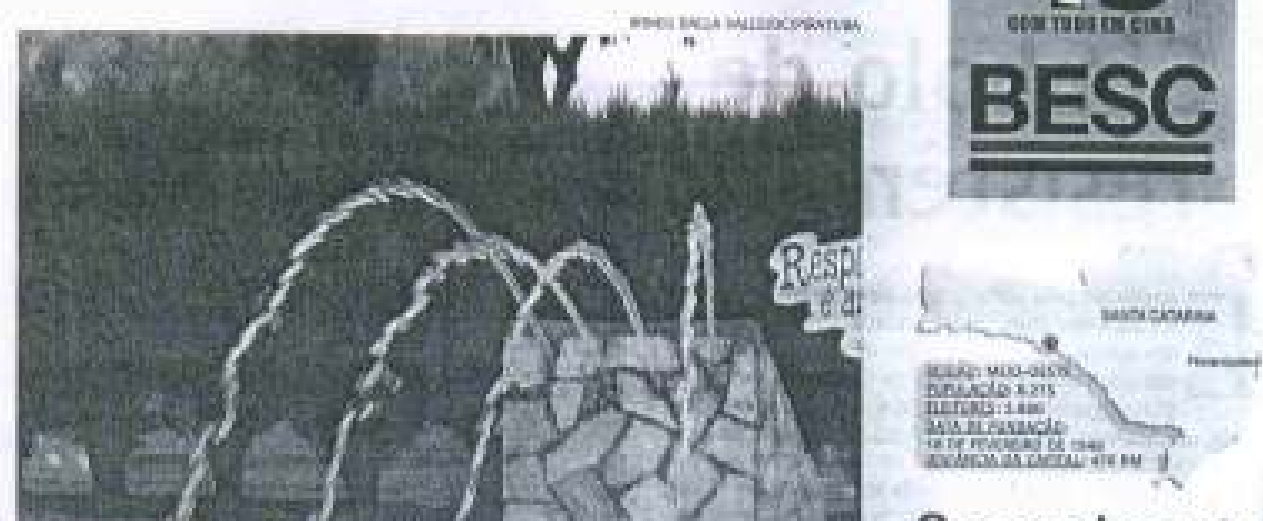

0 crescimento da hotelaria

Qurmt uab cathoce Pliatuha suas pmcuradas douas terrias acha estranha mexniar homa geri te vestindo napkbor e carrecands malhes petis fuis principale in mutricipto.

Mas ess et a sutine ditaria sop

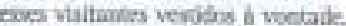
poverimenes de virites evados do pale que mevimeniam a ecosesmia keal.

A rrit huidrin continus ox ex. pandioxin, o conecrio t uan dos princtpois engeregulores de clitals. aximi contio a inime-estrutura de servicas, A mbo-dr-dber venat sam.

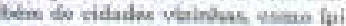
ne elerriba.

As fumas temtais sso necournChatix para o tratarcente de ievesaismos. woena calcuke mernes, hi pertensibo arterid, netermas $\mathrm{e}$ es. tresse

Inirialamese fodt-se beber tewe copo do liquido antes das irfeicoles, e dass litrex eur dia' A to Mida iem aspecto inmoror, t hicas bonataita, flunrtada e possil sabor

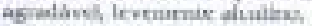

O coeplexio termal, com sals hois cristalinas ahriga umi ifor mass bielas parques of ciowss giro.

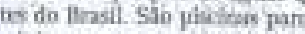
adultos e crancac chovriros no ar livre, duchas e bumpeire inithe duals crm laniv sulfuroses
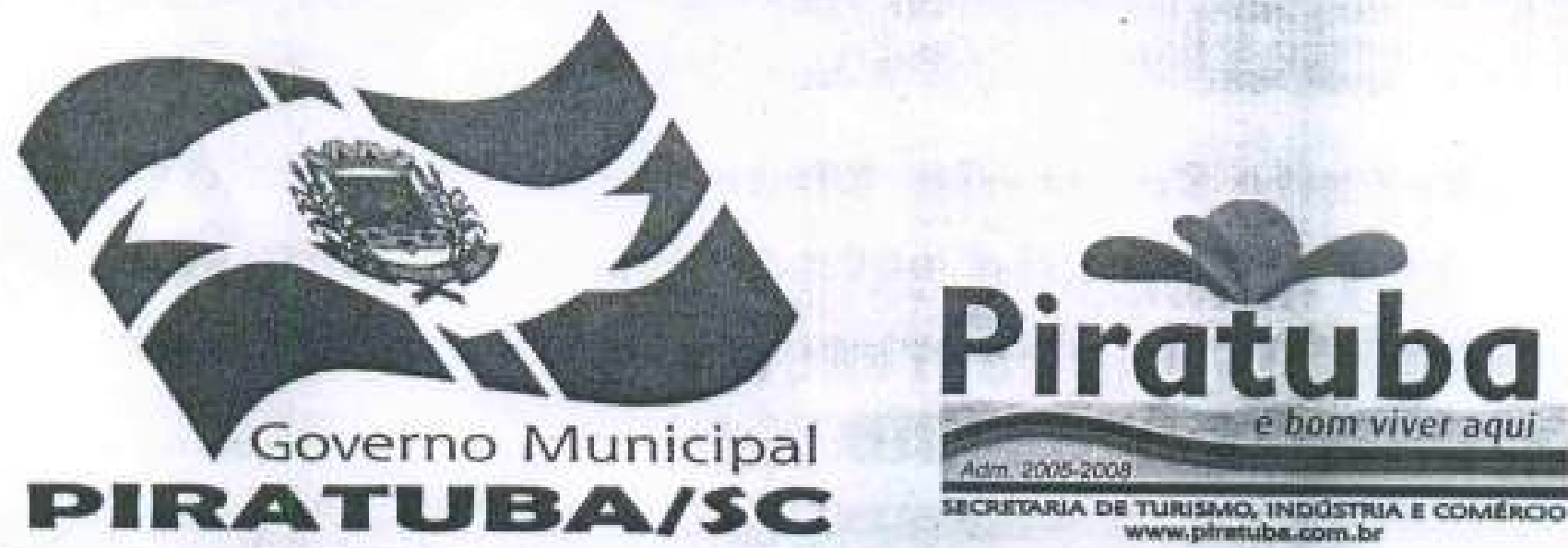


\section{Em pleno frio, um banho a $34^{\circ} \mathrm{C}$}

llha Redonda, balneário catarinense à beira do Rio Uruguai, investe no turismo alimentado por fontes de água quente DMAOC DEBONA

\section{Twuass}

Tomar banho de piscina no inverno nōo parece ser uma boa idelia. Mas o Geste Catarinense oferece opçōes que fasem o turisten ventir-se por algumas horas como se estivesse na Verio, lsso graças as estacóes de águas termais existentes na regiba

Além da tradicional Piratuba, que já tem un tom fluog na estacio mais fria outras estincias de aqua termomineral tambim estlo se esiruterando para atersder mais clientes no Irwerno, Um dos locais e litha Redonda, situada a 15 quilónetros da cidbde de Palmitos mas margens do Riso Uruguai.

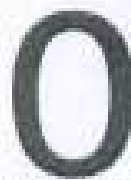

camplese ofitrox uma pisdi. un colertiva cotretra de $12 \mathrm{~m}$ $\times 20 \mathrm{~m}$ com aigin a 74 yraas centigados. De acaido com o atministridor, Elai Damke, u ifux sai bos poçus a jo

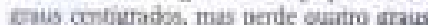
ais passar peda tubulactio. As quatso fontes

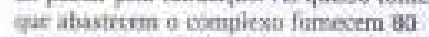
mil bitros de asa par bera sem reovedida.

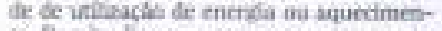
ta Oumie dit que, biesins eam-iemperahy-

Casal five di inta da po. descobriu as peraran ambienite águas termais (be IY gaus. Alem.

fa piscina, hirdar massinem $\mathrm{e} 14$ de por acaso, imenlo.

en 1907

A desuchera das

iguas hemtiak eare. in 200 190\%, como Dud Manud Francistor bes Santos e Mario Suhina da Cooseicto. Des morswam ne cumatidade it Lintis Gascaca, etr saio puctos no anal municipios de Alpesnt. Como a raca no ladu tatarinerrs era

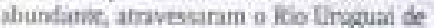
canias, ane a boilidade de the Kivlenta. tue gonesu o- nume grocte a uma das maiores Ihas do Rio L,inupal Deraite e groda Maria Sahima af ásou mum gande

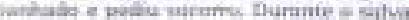

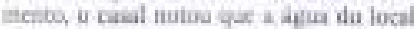
en quente. Dropoks sts Gavicant bantheins

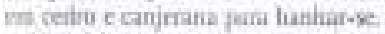
A miticla se esenitsou u partit de xag viapens fura. Sonabi ins. park foner com

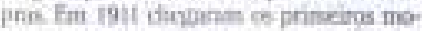
adores de ilita Redontic a familia Avila de-

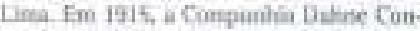

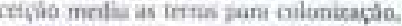

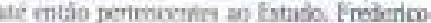
Jotse Logemainn requeredi 70 hectares itr

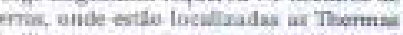
da lihe junto os Departamenta Narsonal fe Prodos an Mineral iDNPMI.

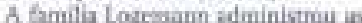

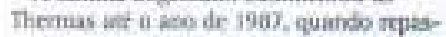
yeu a adminiuraçà do talneduio ấ porféfurr de Palmike Em tow, nto rmpressfin salmitersos eoetpranam a Complexo.

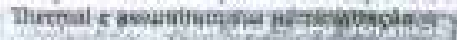

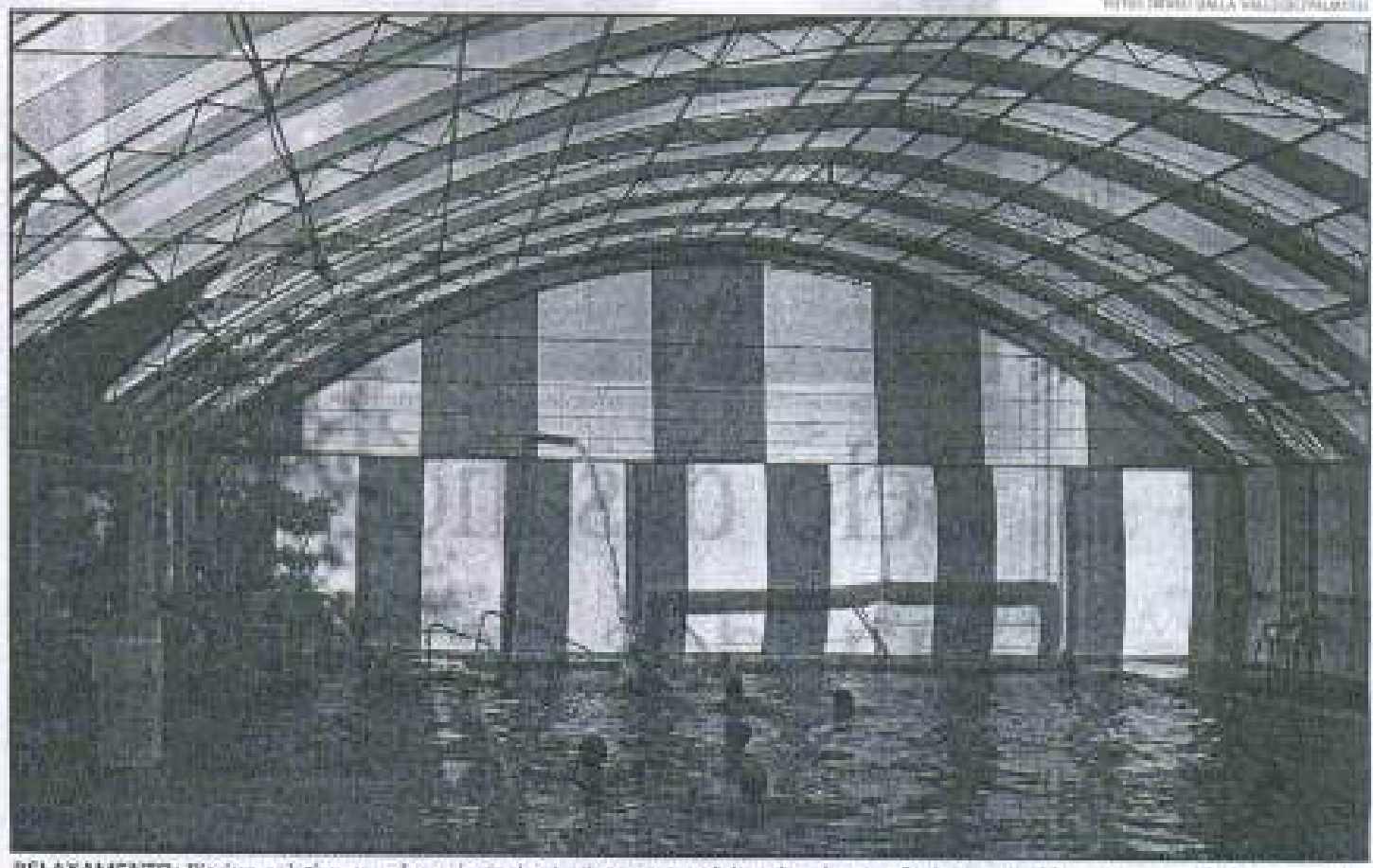

HELAXAMENTO: Pigdina coletiva, um dos principals atratives para es hospedies, é naturaimente uquecitle, sam necessidade de energie.

\section{Visitantes podem escolher entre hotéis e casas}

- primeiro local para hospedagem en liha Redonda. denominado Grande Hotel. foi construido em 1924, por firederica Logenarn.

cor

Inity coms o hoset foil onstrnato o primeim

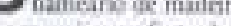
tuadsias, yue ate entios se uilizavaim fus banherins esravades peto oa sed de capadures 5 cutras wavailens por eic

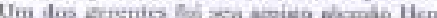
towe Clsutys qoe veio a fita para talar jorebiemas de sinide adquindos cirate comiha! ra Frimeita Gurrn Bunidis (19:41: Im 194h Claudy mestruat o Hocel Brasil, ate

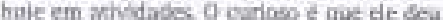
ese nome park evlear pernoziçós pur ser imigranic:

Atuminverm, o conpilexn Thernus tihe Re

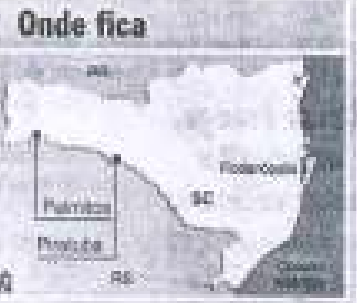

donda ceferest trits locais perre hosectowem e ali. Tienkapini o Hoiel Hnas! Village, Hoted Hrasili e Powada Rtranie da lith Berdonda. Hiti ambem o absuer de cescis particularer mokiliadas 0 turista Ecothe se gaer funer sua comida ou usufruir da oo mida caseira.

lari fines, proprietient do Hour Giniris constranto pela familia em 950 coota que a groumnumia kem clemen-

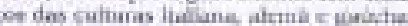
Alem so ctramasco, hi combia de panei. jirparada no fogto a lesha, como imsa, féGo et herata doce. Nò eafe da manhas sajo olerecidon tocrs. salume, cuck bolochaset inta

No notaurante do Hoeel Bessil vilage tambem é senids cosódas no etilo oolonia

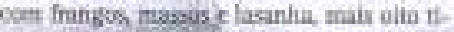

pos de saloda e tuls de solarmesa. No cast colonial ha hirrams que io de porco, mot

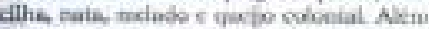
ds hospeciagem nos apuetamentios do hovel

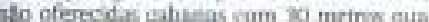
drasos

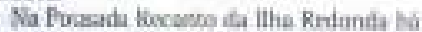
coxinhas e churtasquacin de fitute purs o rio onde o turnta pode propery sua irficicis.

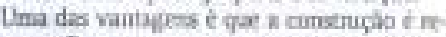
cente. Durante a yenuala es servidi fruffes: 0

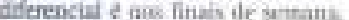

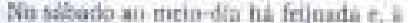

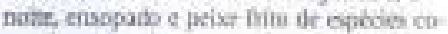

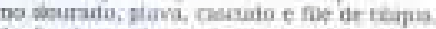
Nu doeminum, ctnmaxco com costelia, $\mathrm{H} / \mathrm{h}$ aportamentus para casais $e$ ate para iluas 6 milias. Oh quartin 'kvamt in nome de jeikes da rogilio

Vej folas ob hrems $\operatorname{ems} \mathrm{SC} \mathrm{em}$

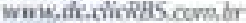

\section{Localidade já atrai turistas argentinos e grupos de idosos}

(1) balnedrie de tha Redonda regievou 60 mil hanhos ne ane passach, mas upenas entre 200 e 300 sina realizados mernsalmenie no periodn do inverno. Por inos, a aitmindstraça do cotmplewe esta elaboraifo uma canpantha de divulger No, atravits de DVDS que merin encamiTharacoves de bVDs qoe serin encami-

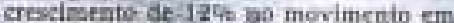
2006. Mesmo ser 1 . fivilcacibo, o balnea-

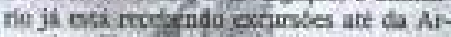
gentina. Um sripo det4t pessoss vindas 6a pais viainho cherfoe na quinta-feira passade para we tengbo de cineo tlias.

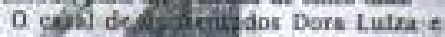
Benjumin Pemin fex-490 quilûmetros de Obera, na Previncia de Masiomen, ste Pal. micos. Hes ficaram encantarins com a is cepsto e a briezan ita vegetachlo do local. Esta fui a primecra vez que visitaram tha Niedonda par indiraçíno de amvigos. Desdr

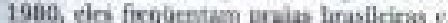
jrindinatmente, as catacinenses it otiveram on Baineario Camberil e Canasviei-

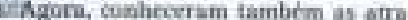
çles do lairriar de Sants Cotarias. 